\title{
Selective immunosuppression in organ transplantation
}

Citation for published version (APA):

Ruers, T. J. M. (1989). Selective immunosuppression in organ transplantation. [Doctoral Thesis, Maastricht University]. Rijksuniversiteit Limburg. https://doi.org/10.26481/dis.19890127tr

Document status and date:

Published: 01/01/1989

DOI:

10.26481/dis.19890127tr

Document Version:

Publisher's PDF, also known as Version of record

\section{Please check the document version of this publication:}

- A submitted manuscript is the version of the article upon submission and before peer-review. There can be important differences between the submitted version and the official published version of record.

People interested in the research are advised to contact the author for the final version of the publication, or visit the DOI to the publisher's website.

- The final author version and the galley proof are versions of the publication after peer review.

- The final published version features the final layout of the paper including the volume, issue and page numbers.

Link to publication

\footnotetext{
General rights rights.

- You may freely distribute the URL identifying the publication in the public portal. please follow below link for the End User Agreement:

www.umlib.nl/taverne-license

Take down policy

If you believe that this document breaches copyright please contact us at:

repository@maastrichtuniversity.nl

providing details and we will investigate your claim.
}

Copyright and moral rights for the publications made accessible in the public portal are retained by the authors and/or other copyright owners and it is a condition of accessing publications that users recognise and abide by the legal requirements associated with these

- Users may download and print one copy of any publication from the public portal for the purpose of private study or research.

- You may not further distribute the material or use it for any profit-making activity or commercial gain

If the publication is distributed under the terms of Article $25 \mathrm{fa}$ of the Dutch Copyright Act, indicated by the "Taverne" license above, 
Selective immunosuppression in organ transplantation 



\section{Selective immunosuppression in organ transplantation}

Proefschrift

ter verkrijging van de graad van doctor aan de Rijksuniversiteit Limburg te Maastricht, op gezag van de Rector Magnificus, Prof. Dr. F.I.M. Bonke, volgens het besluit van het College van Dekanen, in het openbaar te verdedigen op vrijdag 27 januari 1989 om 16.00 uur

door

Theodoor Jacques Marie Ruers

geboren te Sittard in 1956. 
Promotor:

Co-promotores:

Beoordelingscommissie: Dr. T. Beveridge (Basel)

Prof. Dr. F.T. Bosman (voorzitter)

Prof. Dr. R.A.P. Koene

Prof. Dr. H.A.J. Struyker Boudier

Prof. Dr. N.L. Tilney (Boston) 
In memory of my parents To Claire 



\section{Contents}

PREFACE

CHAPTER I

Introduction to immunobiology of transplantation.

1.1 Major Histocompatibility Complex (MHC)

1.2 T cell activation sequence

1.3 Rejection mechanisms

1.4 Kinetics of cellular immune response in allograft rejection

CHAPTER II

Introduction to immunosuppressive therapy.

2.1 General characteristics

2.2 Azathioprine

$\begin{array}{lll}2.3 & \text { Glucocorticosteroids } & 16\end{array}$

2.4 Cyclosporin A $\quad 18$

2.5 Anti-thymocyte globulin 19

$\begin{array}{ll}2.6 & \text { Monoclonal antibodies } \\ 2.7 & 20\end{array}$

$\begin{array}{ll}2.7 & \text { Concluding remarks }\end{array}$

CHAPTER III

Introduction to and discussion of the experimental work

3.1 Selective immunosuppression by interference with enzymatic reactions within lymphocytes

3.2 Selective immunosuppression by local treatment of the allograft

$\begin{array}{ll}3.2 .1 & \text { Immunological aspects of local treatment }\end{array}$

3.2.2 Pharmacological and therapeutic aspects of local treatment 28

SUMMARY

SAMENVATTING 
STUDIES ON SELECTIVE IMMUNOSUPPRESSION BY

INTERFERENCE WITH ENZYMATIC REACTIONS WITHIN

LYMPHOCYTES

Study 1 The effect of 2'deoxycoformycin on skin allograft rejection in rats.

Study 2 Potency of 2'deoxycoformycin and cyclosporin A on rat skin allograft survival.

Study 3 The effect of 2"deoxycoformycin and deoxyadenosine on human $\mathrm{T}$ cell function.

STUDIES ON SELECTIVE IMMUNOSUPPRESSION

BY LOCAL TREATMENT OF THE ALLOGRAFT

Study 4 Local treatment of renal allografts, a promising way to reduce the dosage of immunosuppressive drugs.

Study 5 Immunohistological observations in rat kidney allografts following local steroid administration.

Study 6 The effect of local immunosuppression, in the absence of significant systemic immunosuppression, on rat cardiac allograft survival

Study 7 The effect of steroids on the regulation of MHC class II expression on human non-lymphoid tissue.

Study 8 Cellular proliferation at the site of rat cardiac allografts and the influence of immunosuppressive therapy. 


\section{Preface}

The last decade has witnessed a considerable development in the field of transplantation. Advances in surgical techniques, tissue matching and immunosuppressive therapy have made it possible to transplant both a larger number and an increasing variety of organs. Liver transplantantion and heart transplantation are no longer considered experimental and have become common practice in many countries. Indications for kidney transplantation have been widened and nowadays the estimated need for renal transplants in the western countries varies from 40 to 50 per million inhabitants per year.

Success in clinical transplantation depends upon prevention of the process of rejection. The traditional approach to the phenomenon of rejection has been to minimize the rejection response by matching for HLA antigens of donor and recipient and subsequently modify the recipient immune response by several immunosuppressive drugs. In recent years advances in both HLA matching and immunosuppressive therapy have been achieved and 3 year kidney allograft survival up to $70 \%-80 \%$ has been reported during several immunosuppressive regimens including, cyclosporin $\mathrm{A}$, steroids and monoclonal anti- $T$ cell antibodies. Although graft acceptance occurs to a certain level, complete immunological tolerance does not develop in clinical transplantation and immunosuppressive therapy has to be continued lifelong to prevent rejection. Unfortunately,however, the therapeutic index of many immunosuppressive agents is low and considerable side effects are noticed. To improve the quality of life of the transplanted patient continuing search for more selective immunosuppressive agents is required. This thesis deals with different approaches to induce more selective immunosuppression in organ transplantation. 


\section{Introduction to immunobiology of transplantation}

\subsection{Major Histocompatibility Complex (MHC)}

The major barrier to transplantation is provided by the major histocompatibility antigens (MHC antigens). In man, MHC antigens can be divided in MHC class I and MHC class II antigens. These antigens are strong immunogens and are of major importance in the discrimination between self and non-self(1). MHC class I molecules occur on virtually all cell surfaces; MHC class II molecules are present on the surface of $B$ lymphocytes, activated $T$ lymphocytes, monocytes, dendritic cells, Langerhans cells, Kupffer cells and several tissue cells, amongst others; capillary endothelial cells(2). MHC class I antigens are considered to be the target determinant of cytotoxic $\mathrm{T}$ lymphocytes (CTL) and have a regular task in immune reactions against viruses(3), MHC class II antigens are target determinants of $\mathrm{T}$ helper/ inducer cells and are assumed to be involved in delayed-type hypersensitivity (DTH) and immunoregulation(4). In clinical practice matching for MHC class I and MHC class II antigens has a beneficial effect on prolongation of allograft survival(5). The effect of MHC class II antigen matching however appears to be stronger $(6,7)$.

\section{$1.2 \mathrm{~T}$ cell activation sequence}

Presentation of donor MHC class II antigens by antigen presenting cells such as monocytes, macrophages, dendritic cells or vascular endothelial cells may lead to the initiation of the immune response(8). Clones of $\mathrm{T}$ helper/inducer cells having receptors for the MHC class II antigens of the particular donor perceive the foreign antigen and become activated while releasing factors that induce antigen presenting cells to release interleukin 1 (IL 1) $(9,10)$. Activation of $T$ helper cells also results in the formation of receptors for IL 1, IL 2, transferrin and insulin(11-14). The release of IL 1 by antigen presenting cells potentiates the immune response(15) and results in the release of IL 2 by the T helper cells $(16,17)$. The IL 2 signal provides a major stimulus in the ongoing immune response and results in differentiation and expan. sion of both $\mathrm{T}$ helper/inducer cells and $\mathrm{T}$ cytotoxic/suppressor cells(1,8). IL 2 also stimulates the release of $\mathrm{B}$ cell growth factor that stimulates the proliferation of antigen activated B cells(18). Moreover, IL 2 causes the release of interferon- $\gamma$ (IFN- $\gamma$ ) which plays a role during the activation of macrophages. The release of IFN- $\gamma$ by 
activated $T$ cells results further in an increase of MHC class II antigen expression on grafted tissue which initiates a vicious cycle since $\mathrm{T}$ helper cells are restricted to MHC class II antigens for their activation $(19,20)$.

Besides IL 2, other lymphokines are produced by the Thelper subset which modulate the behaviour of a large array of cells involved in the immune reactions. It is known that attraction of monocytes to sites of lymphokine release is caused by macrophage chemotactic factor while after migration the monocytes are kept at that site by migration inhibition factor. Thus, the release of IL 2 and other lymphokines by $T$ helper cells results in activation of macrophages, $B$ cells and cytotoxic $T$ cells as well. as causes an increase in graft immunogenicity.

\subsection{Rejection mechanisms}

In normal experimental animals, vascularized allografts show a histological reaction which can be defined as cellular rejection because of the mass of infiltrating mononuclear leucocytes found within the graft $(1,8,21,22)$. Most of the cells which arrive in the graft early after transplantation are lymphocytes which migrate out of the capillary and venous beds. After 4 to 7 days, however, a remarkably heterogeneous collection of cell types have appeared within the graft with lymphoid cells, both $T$ helper and $T$ cytotoxic/suppressor cells, monocytes, macrophages and polymorphonuclear leucocytes. Although considerable investigations have been performed on functional capacities of these infiltrating cells, the precise mechanisms which induce rejection and the relative importance of various cell types and mediators is yet not fully understood. In general, cellular immunological reactions elicited against the graft can be divided into DTH and cell mediated cytotoxicity (CMC) $(1,8,21,22$,). During DTH reactions soluble mediators are released by $\mathrm{T}$ lymphocytes which may have a direct detrimental effect on the graft or which may lead to activation of monocytes, macrophages and polymorphonuclear leucocytes which in turn may induce tissue destruction. Once the DTH process has started it lacks specificity of direct cytolysis such as in CMC. During cell mediated cytotoxicity, generated CTL's recognize antigens on the allografted cells via an antigen specific receptor. Binding of CTL's to cells carrying the specific determinant recognized by the CTL's results in lysis of the antigen bearing cell. While CTL activity is easily demonstrated at first, later stages of rejection may involve non- $T$ killer cell activity, since a significant number of B lymphocytes, null cells and natural killer(NK) cells also appear in the graft.

When the host has been primed to donor antigens before transplantation, a more accelerated process, often marked by antibody-mediated vasculitis, is common $(1,8,23)$. Humoral immunological reactions can damage a graft via complement dependent cytotoxicity and via antibody dependent cellular cytotoxicity. In the first, binding of complement, by an immune complex, e.g. antibody bound to an allografted cell, results in activation of the cascade of complement factors. Such an 
activation of complement factors can result in lysis of the cell to which the complement factors are bound via the immune complexes. In the second type of humoral reactions, antibody binds specifically to a cell of the graft and non-specifically to an effector cell of antibody dependent cellular cytotoxicity, upon which the transplanted cell is lysed by the effector cell.

\subsection{Kinetics of cellular immune response in allograft rejection}

During the course of allograft rejection immunocompetent cells appear to migrate among various lymphoid depots in the body, the peripheral circulation, the lymphatic circulatory channels, and the allograft(21). Nemlander et. al. studied the flow of white cell traffic to and from rat renal allografts and found that the traffic was bidirectional and increased exponentially until day 4(24). Thereafter, proliferative activity occurred within the specific compartments with little intercompartmental exchange. Originally it was proposed that sensitized cells mature within the central lymphoid tissue and subsequent $\rrbracket y$ migrate as mature effector cells to the target tissue and mediate tissue destruction(25). However donor-specific cytotoxic $\mathrm{T}$ cells appear earlier in the graft than in the spleen or lymph nodes of the host, and the specific cytolytic activity remains highest in the graft until the rejection process progresses to the point where tissue blood flow is compromised $(1,8)$. Moreover, mitotic activity has been shown amongst early infiltrating cells $(26,27)$. On day 4 after transplantation, about $25 \%$ of the infiltrating cells in rat renal allografts incorporated tritiated thymidine within 1 hour after labeling, indicating that these cells are actively synthesizing DNA(26). The early appearance of cytotoxic T cells and the synthesis of DNA in grafts suggests a major role for differentiation in situ. Indeed, recent studies by Ascher et. al.(28) showed that CTL can mature within sponge matrix allografts. These investigators placed sponge matrix allografts in recipient mice and irradiated the recipient on day 5 with the graft selectively shielded from irradiation. Anti-donor cytotoxic $T$ cells developed to a high level in the shielded sponge matrix allografts leading to the conclusion that CTL could mature within the graft independent of the host lymphoid system from day 5 after transplantation. However, differentiation in situ is not the sole mechanism for accumulation of effector cells within the graft. Studies by Strom et. al.(29) showed that when the hearts from two different donor strains were transplanted into the same recipient cytotoxic $T$ cells to both targets were found in both grafts. These experiments prove the existence of some property of the activated cell that directs its localization to areas of inflammation. 


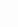




\section{Introduction to immunosuppressive therapy}

\subsection{General characteristics}

In organ transplantation the purpose of immunosuppressive agents is to inhibit the immune response to foreign antigens (non-specific immunotherapy) or even more ideal to a particular foreign antigen (specific immunotherapy). The latter type of therapy, in which suppression of the immune response is directed to donor alloantigens without suppression of other antigens, confers particular advantages in that the patient's immune response to additional foreign antigens (such as infectious agents) remains normal. However, attempts to induce specific immunosuppression are still experimental and in clinical transplantation immunosuppression is limited to the use of non-specific immunotherapy which directly interferes with the various steps in the immunological cascade. Unfortunately it is a common but variable feature of all these non-specific immunosuppressive agents that they cause a generalized depression of host defense mechanisms, accounting for certain frequencies of infectious diseases or even neoplasia. The immunosuppressive actions of many compounds are often only obtained at dosages close to toxicity and regular clinical and biological surveys must be made in order to gradually decrease in time the dosage in case of side effects. Agents at present used in clinical practice are azathioprine, steroids, cyclosporin A, anti-thymocyte globulin and anti-T cell monoclonal antibodies.

\subsection{Azathioprine}

The antimetabolite azathioprine is an imidazole derivative of 6-mercaptopurine. The predominant immunosuppressive effect of azathioprine and its metabolites is to block mitosis or proliferation of immunologically competent lymphoid cells(30-32). A wide variety of mechanisms have been proposed including: interference with enzymes and coenzymes, incorporation into nucleic acids and inhibition of de novo purine synthesis(31). These actions may explain the inhibition of DNA synthesis and the influence of the drug on the synthesis and function of RNA. Since antigen stimulation causes cell division and proliferation, the general antiproliferative activity of azathioprine allows it to affect rapidly dividing activated $B$ and $T$ cells. The drug suppresses the primary immune response but has little effect upon the secondary responses; thus it is useful in preventing acute rejection but not 
in reversing ongoing rejection. Three year graft survival for cadaveric kidney grafts among patients receiving a standard combination of azathioprine and steroids has been found to be about $60 \%$. The major disadvantage of the drug is its myelosuppressive effect. Other complications such as lymphoproliferative disorders or liver disease have as well been related to toxicity of the drug.

\subsection{Glucocorticosteroids}

For three decades glucocorticosteroids (and azathioprine) have been successfully used as the usual or conventional posttransplant immunosuppressants. Glucocorticosteroids have been shown to have a wide range of effects on virtually every phase and component of the immune response. It is important to realize that the clinical effects of the drug may be caused by its anti-inflammatory properties as well as by its immunosuppressive properties. The anti-inflammatory activities allow it to reduce migration of neutrophils in response to chemotactic stimuli as well as to reduce inflammation by inhibiting lysosomal enzyme release by neutrophils. The effects of the drug on the immunological cascade are complex and it is difficult to determine which of the actions discussed below are the biologically most relevant. Steroids enter the cell membrane and bind to specific cytoplasmatic steroid receptors forming a complex that penetrates the nucleus and interacts with acceptor sites in the nucleus. This interaction leads to specific effects on individual genes, mainly at the level of transcription which results in modifications of enzyme synthesis, either induction or repression, with subsequent expression of the steroid effect on the target tissue $(31,33,34)$. Although intracytoplasmic corticosteroid receptors may be important as a common pathway for the corticosteroid effect on immunoreactive cells, variations in corticosteroid receptor-related parameters, such as density, affinity, or binding constants, could not alone account for a range of heterogeneous responses of immunoreactive cells to corticosteroids. Other metabolic effects of steroids may also play a role in the effect of the drug on the immune response $(33,34)$.

Concerning the action of steroids on the $\mathrm{T}$ cell activation sequence it was demonstrated that cytokine production induced by antigen or mitogen is inhibited by the drug at concentrations readily achieved in clinical practice(30-35). For example the drug interfered with the synthesis of mRNA for IL 2 and IFN- $\gamma(36)$. Whether the effect on the production IL 2 and IFN- $\gamma$, however, is a primary effect or whether it is secondary to the decreased production of IL 1(37) is still a matter of discussion. The inhibition of IL 2 may be of particular importance since in this way the drug deprives the essential trophic factor for $\mathrm{T}$ cell proliferation and generation of cytotoxic $\mathrm{T}$ cells. Once generated, cytotoxic $\mathrm{T}$ cells are capable of executing their cytotoxic activity despite the presence of steroids. Inhibition of cytokine production may be a crucial effect of the drug since it was observed that steroid associated inhibition of the immune response can be reversed by the provision of exogenous IL 2 , which indicates that the early steps in the activation process are not inhibited by the 
drug $(38,39)$. In addition to their ability to interfere with the $T$ cell activation sequence, steroids may play a role in the process of antigen presentation and recognition. Several experiments suggest that MHC class II expression on antigen presenting cells such as macrophages can be affected by the drug $(37,40)$. Since one of the conditions under which antigen presenting cells can express themselves is corecognition of the immunizing antigen and class II MHC antigens, inhibition of MHC class II antigen expression on these cells would clearly interfere with the process of antigen recognition.

Although glucocorticosteroids exhibit multifaceted effects, most of the actions are restricted to interference with the afferent limb of the immune response. Effector mechanisms such as CMC, ADCC or NK cytotoxicity are generally minimally or not affected by the drug while variability of responses have been described with regard to antibody production $(31,33,34)$. In the past much attention has been paid to some specific in vivo effects of steroids such as the shift in traffic of circulating white cells(33). For example, a brief and brisk lymphocytopenia occurs in man following the administration of a steroid dose. Redistribution of circullating lymphocytes into lymphoid tissue has been considered responsible for this effect in man. In experimental animals the depletion has also been contributed to cell lysis, a mechanism which more or less defines the difference between corticosteroid sensitive species and corticosteroid resistent species. The importance, however, of actions specifically occurring in vivo remains difficult to judge.

In clinical practice glucocorticosteroids have been widely used in maintenance immunosuppression, together with azathioprine or cyclosporin A, as well as in treatment of rejection episodes. In the past, maintenance therapy consisted of high steroid dosages immediately after transplantation tapered down to lower dosages afterwards. However the adverse effects of steroids, such as infection, impaired wound healing and gastro-intestinal bleeding have made it desirable to give dosages as small as possible. Generally two protocols for maintenance immunosuppression have been described in which either 'low dose' (about $20 \mathrm{mg} /$ day) or 'high dose' (about $100 \mathrm{mg} /$ day) steroids are administered together with azathioprine or cyclosporin A. Clinical trials studying the effect of these two regimens agree that the complication rate in the low dose group is significantly lower, however, concerning graft survival variable results have been published( $30,32,41-46)$. Graft survival was either identical in both the high dose and low dose group or was higher in the high dose group. Today, immunosuppressive protocols that include steroids all use the low dose regimen.

Steroids are still used as primary drug for reversal of acute rejection episodes, although other options for treatment of rejection also now include polyclonal antilymphocyte serum and several monoclonal antibodies. For treatment of acute rejection, steroids are given at high dosages for short periods (e.g. $1 \mathrm{~g}$ methylprednisolone/day for 3 days). Most rejection episodes can be reversed by the drug (steroid sensitive), however a certain number are steroid resistant or show only a short period of reversibility. Continued use of high dosages of steroids during these two forms 
of rejection has excessively high patient morbidity with low allograft survival. Balanced against the beneficial effects of glucocorticosteroids, are the well known complications of steroid excess, such as serious infections, disturbed wound healing, fluid retention, gastro-intestinal bleeding, diabetes, easy bruiseability and myopathy(32). However during the use of low dose steroids in addition to cyclosporin A the incidence of these complications has essentially decreased.

\subsection{Cyclosporin A}

In 1972 the fungal metabolite cyclosporin A was discovered. In subsequent years the agent showed remarkable immunosuppressive properties and presently the drug is used as primary immunosuppressant during maintenance therapy, either with or without the addition of steroids.

The predominant effect of cyclosporin $A$ appears to be interference with $T$ helper cell function $(30-32,47)$. Cyclosporin A blocks the release of several lymphokines from $T$ cells such as IL 2 , IFN- $\gamma, \mathrm{B}$ cell differentiation factor and cytotoxic differentiation factor. It has been demonstrated that the drug blocks the induction or production of lymphokine mRNA(48). Cyclosporin A, however, does not as readily interfere with IL 2 receptor expression while the responsiveness of activated $\mathrm{T}$ lymphocytes to lymphokines is also quite resistant to the drug(49). In addition, experimental evidence suggest that cyclosporin $\mathrm{A}$ does not extensively interfere with T cell suppressor activity $(47,50)$. In summary, the immunosuppressive effect of cyclosporin $\mathrm{A}$ is mostly related to its ability to inhibit lymphokine production; this results in lack of necessary help stimulants and consequently, T helper cells, cytotoxic $\mathrm{T}$ lymphocytes, B cells and macrophages are not fully activated. With this as primary mechanism of action, cyclosporin $A$ has little effect on bone marrow elements so that the host defenses are not as impaired with cyclosporin $\mathrm{A}$ as with a more widely acting immunosuppressive agent such as azathioprine.

The introduction of cyclosporin $\mathrm{A}$ in clinical practice resulted in an important improvement of graft survival rates. In renal transplantation cyclosporin A treatment, with or without steroids, results in $70 \%$ to $80 \%$ graft survival at 3 years, which clearly exceeds graft survival during conventional treatment using azathioprine and steroids(30,51,52). Besides improved immunological outcome, cyclosporin A shows additional benefit of diminished incidence of severe infectious disease. Despite these positive results the drug has considerable side effects, all of which need careful consideration. Sidle effects from cyclosporin A include moderate to severe nephrotoxicity, hepatotoxicity, hypertrichosis, tremors, gingival hypertrophy and occasionally painful neuropathy $(30,53,54)$. Nephrotoxicity is the most frequent and meanwhile frustrating complication of cyclosporin A treatment. It is this complication that has led to several postoperative protocols in which conventional immunosuppressive agents such as azathioprine, steroids or ATG are initially given after transplantation followed by the administration of cyclosporin A several days 
afterwards $(32,53)$. In addition, the unknown long term nephrotoxic effect of the drug was used by several groups as an argument for conversion of cyclosporin $\mathrm{A}$ to azathioprine several weeks after transplantation(53,55-57).

\subsection{Anti-thymocyte globulin, (ATG)}

In an attempt to induce selective measures of immunosuppression several preparations of anti-thymocyte or anti-lymphocyte antibodies (especially against $T$ lymphocytes) have been developed. These preparations were designed to attack principally the infiltrating mononuclear cells observed in allograft biopsies. Such suppression conceptually could retain those host immune responses which are independent of $T$ lymphocyte function.

Heterogeneous antisera to human lymphocytes (ALG) or thymocytes (ATG) are prepared from the sera of animals (horse, rabbit, goat) which have been immunized with human lymphocytes or thymocytes. The immunosuppressive potency of these sera is confined almost exclusively to the IgG fraction which is usually isolated for use in humans. However the polyclonal products obtained consist of a heterogeneous group of antibodies not only directed to $T$ cells, but also to B cells and nonlymphoid cells. In vivo administration of ATG results in marked lymphopenia and the immunosuppressive effect of the drug was originally attributed to classic complement-mediated lysis of lymphocytes(58). However, it became evident that the immunosuppressive effect of ATG considerably outlasted the treatment period, and that this long lasting effect was not necessarily accompanied by lymphopenia $(59,60)$. Therefore, several other mechanisms of action have also been proposed such as: the induction of suppressor cells after successful ATG treatment and the repopulation by short-lived lymphocytes after ATG treatment $(59,61,62)$.

ATG has been administered to allograft recipients either prophylactically to prevent rejection or for treatment of acute rejection episodes(59-61). Most "prophylactic' protocols have indicated fewer early rejection episodes, however, the difference in long term function in the ATG treated patients compared with that achieved in conventional (steroids and azathioprine) treated patients has often failed to reach statistical significance $(32,60,61)$. Moreover, with the introduction of cyclosporin $A$, the prophylactic use of ATG seems even more limited although protocols are being used nowadays in which ATG and cyclosporin A are given sequentially in the early period after transplantation. These protocols are designed to prevent the use of cyclosporin A early after transplantation and in this way to circumvent nephrotoxicity. Although this approach shows promising results(63), the major application of ATG seems reversal of acute rejection episodes. During acute rejection, adjunctive ATG along with steroids resulted in better graft survival compared to steroids alone(64). Moreover, ATG treatment resulted in a steroid sparing effect while the drug proved also effective when given as the sole agent to treat rejection $(60,61,65)$. 
There are a number of side effects that occur during ATG treatment. Fever and chills develop during the initial infusion in many patients and probably are the result from pyrogen release during rapid lymphocytolysis. Other side effects are pruritus, thrombocytopenia, diffuse myalgias, and opportunistic infections. Severe reactions of anaphylaxis have also been reported $(32,60)$. At present the agent is still widely used to treat severe rejection episodes although its use may be replaced by the introduction of monoclonal antibodies.

\subsection{Monoclonal antibodies}

Using hybridoma technology it has become possible to produce reagents reactive only with $T$ cells or, even more importantly with specific $T$ cell subsets(66). As a result monoclonal antibodies can be used to manipulate selected $T$ cell populations relevant for rejection, while sparing most of the host's immune competence. In this way, side effects of immunosuppressive therapy can be reduced and potency increased. Several mechanisms of action for monoclonal antibodies have been proposed $(59,67)$. By analogy with ATG, simple clearance of the cells opsonized by the antibody may play a role. However, a powerful immunosuppressive effect of monoclonal antibody therapy is also observed without destruction of lymphocytes $(59,68)$, which leads to other concepts of action such as functional receptor blocking or receptor modulation(59). For example, anti-T3 monoclonal antibodies may interfere with $\mathrm{T}$ cell activation by blocking the $\mathrm{T} 3$ receptor molecule. Similarly, anti-T4 or anti-T8 monoclonal antibodies may interfere with cell adhesion necessary for interaction between cells in immunologic responses. Besides blocking, modulation as well as shedding of the receptor or antigen (e.g. Ia antigens) may be important for the induction of the immunosuppressive effect. For example, modulation of the T3 complex was found during OKT 3 treatment $(59,61)$. However receptors or antigens vary in the degree to which they can be made to undergo modulation or shedding.

In order to further increase specificity of the immunosuppressive effect, monoclonal antibodies have been made against $T$ cell activation antigens. For example anti-IL2 receptor monoclonal antibodies have been developed which show a significant immunosuppressive effect in vivo(69). In the same context anti-Ia monoclonal antibodies have been tested.

Rather than relying on intrinsic biological effects of monoclonal antibodies, the effect on the target cell may be employed by toxic substances conjugated to the antibody e.g. Pseudomonas toxin conjugated to anti-IL2 receptor antibody(70). For this to work it may be that the antibody must be directed against an antigen that is internalized so that the toxic material will be carried into the cell(70-72). Another attractive approach to produce immunotoxins was recently presented by Strom et. al.(73). They replaced the DNA sequences of Diphtheria toxin that code for the receptorbinding protein domain with human IL2 DNA sequences. In this way they were able 
to produce a recombinant IL2 toxin hybrid molecule that showed immunosuppressive properties.

Most of the work with monoclonal antibodies, however, is still experimental and to date clinical application is almost limited to monocional antibodies directed to the T3 complex, e.g. OKT3. Clinical trials with OKT3 have demonstrated prompt reversal of established rejection episodes $(74,75)$. Superior reversal rates with OKT3 compared with high dose steroids have also been reported(75), and presently OKT3 is generally accepted as an immunosuppressive agent to treat acute rejection. Concerning the prophylactic use of monoclonal antibodies, experience is still limited. Several studies report a lower incidence of rejection episodes in the first few weeks after transplantation during prophylactic use of OKT3(76,77). Eventually however, graft survival rates and kidney function are often comparable to controls and hence at this moment the major therapeutic advances of monoclonal antibody treatment appears to be at the time of allograft rejection.

Despite the striking immunosuppressive effect, several limitations of OKT3 monoclonal therapy have been identified. For example many patients show adverse reactions shortly after the first injection with OKT3. Fever, chills and bronchospasm are most frequently observed and are explained by the release of endogenous mediators from lymphocytes(75). Of major concern is the development of both idiotypic and non-idiotypic antibodies to OKT3 which seriously limits the repeated use of the agent.

\subsection{Concluding remarks}

At present many posttransplantation immunosuppressive protocols exist in which drugs described above are combined in several different ways. In general, it can be stated that for maintenance immunosuppressive therapy either cyclosporin $\mathrm{A}$, steroids or azathioprine are used in several combinations while sometimes ATG is added for a short period to the maintenance protocol. It is worth noting that triple or even quadruple immunosuppressive therapy is being used now. By blocking the immune response at several points combination therapy may increase the immunosuppressive effect. However, with the use of multiple agents the relation between therapeutic and adverse effects becomes more complex and hence clinical monitoring more complicated. For the treatment of acute rejection episodes either steroids, ATG or monoclonal antibodies are used while sometimes combinations of these agents are appropriate. 



\section{Chapter III}

\section{Introduction to and discussion of the experimental work}

Because of the success of new immunosuppressive agents such as cyclosporin A and anti- $\mathrm{T}$ cell monoclonal antibodies the question may be raised whether the search for newer ways of immunosuppression is still necessary. However, we do know that many problems remain regarding immunosuppressive treatment. At least $10 \%$ of the primary renal transplants are rejected within one year after transplantation, while there is a much higher failure rate with uncontrollable rejection in patients receiving second or third transplants. Moreover, the occurrence of slow insidious chronic rejection is still a major problem in clinical transplantation. Despite recent advances in immunosuppressive therapy, the estimated ten year graft survival for cadaveric donor kidney allografts performed today is about $40 \%$ (78). Also, we are still confronted with significant systemic side effects of present immunosuppressive regimens. Nephrotoxicity of cyclosporin $A$ is one of the major side effects observed. On the other hand the use of biological agents such as monoclonal antibodies is still limited by the occurrence of antibody responses to these agents which seems to prevent repeated use. So, the search for new immunosuppressive agents is still required although major improvements in today's immunosuppressive protocols will only be achieved if these new agents will selectively attack the rejection process without showing side effects on other organs or functions of the immune system.

In this thesis two different approaches are investigated to fulfil these high criteria and to induce selective suppression of the rejection response. In the first part of the thesis it is studied whether interference with enzymatic reactions, more or less specific to lymphocytes, is an effective approach to induce selective immunosuppression. In the second part it is investigated whether local treatment of the allograft, without systemic immunosuppression, is an appropriate way to selectively attack the rejection response.

\subsection{Selective immunosuppression by interference with enzymatic reactions within lymphocytes}

In children, congenital deficiency of the enzyme adenosine deaminase is strongly associated with a form of severe combined immunodeficiency(79-82). The enzyme adenosine deaminase (ADA), active within the purine metabolism, catalysis the deamination of adenosine and deoxyadenosine to inosine and deoxyinosine respectively. Children with ADA deficiency show thymus hypoplasia, profound impair- 
ment of $\mathrm{T}$ lymphocyte function and a variable loss of $\mathrm{B}$ cell function(81,82). The disease is almost restricted to the lymphoid tissue with no or only minor impairment of other organs. Also from studies with azathioprine it is known that interference with the purine metabolism results in lymphocyte dysfunction. However, as with azathioprine, the mechanism by which ADA deficiency results in lymphocyte dysfunction is still controversial(83-91). It is proposed that absence of the enzyme ADA leads to accumulation of deoxyadenosine (AdR) and deoxy'ATP (dATP) within lymphocytes and that either one or both of these metabolites would interfere with normal lymphocyte function. For example accumulation of dATP would result in inhibition of ribonucleotide reductase, the enzyme which catalysis the reduction of nucleoside diphosphates to the respective deoxynucleoside diphosphates. Inhibition of this pathway will cause depletion of DNA precursors and hence disturbed DNA syrithesis. Unlike many other disturbances of the purine metabolism, for example induced by drugs such as azathioprine, ADA deficiency mainly leads to selective lymphocyte dysfunction. Selective toxicity for lymphocyte function is explained by the fact that the enzyme AdR kinase, which phosphorylates the freely diffusible AdR to the non-diffusible deoxynucleoside derivative, is largely localized in lymphoid cells(84). Thus in the absence of ADA, which normally catalysis the deamination of adenosine and AdR, lymphocytes will selectively trap AdR by their more or less unique ability to metabollize AdR by the enzyme AdR kinase. This will lead to the accumulation of AdR and dATP selectively within lymphocytes which both are supposed to promote cell dysfunction.

$2^{\prime}$ deoxycoformycin $\left(2^{\prime} \mathrm{dcf}\right)$, a microbial fermentation product, is an extremely tightly binding inhibitor of ADA(92). This drug provides therefore the possibility of creating a metabolic state of ADA deficiency with specific impairment of lymphocyte function(93-95). Such manipulation of the purine metabolism that primarily appears to effect lymphocytes seems an attractive approach to induce immunosuppression and is further investigated in this thesis.

In the first two studies the effect of $2^{\prime} \mathrm{dcf}$ on rat skin allograft survival was tested and the potency of the drug was compared to that of cyclosporin A. In the model tested, in which skin transplantation was performed from Brown Norway $\left(\mathrm{RT}^{\mathrm{n}}\right)$ to Lewis ( $\mathrm{RT}^{\mathrm{L}}$ )rats, $2^{\prime}$ def proved to be a potent immunosuppressive agent. Continuous infusion of the drug resulted in significant prolongation of graft survival in a dose dependent way. At the optimal dose, graft rejection was completely suppressed during therapy. In its potency $2^{\prime}$ dcf resembled cyclosporin A, both drugs showed comparable graft survival times. Blood cell analysis during immunosuppressive therapy with $2^{\prime}$ def confirmed earlier observations that ADA inhibition preferentially affects lymphocytes whille neutrophils are resistant to the drug. The lymphocytotoxic effect of 2 'dcf however was severe; splenic weight and lymphocyte count decreased significantly. $T$ cells as well as B cells were affected by the drug while within the $T$ cell population helper $T$ cells were more sensitive than cytotoxic / suppressor $\mathrm{T}$ cells.

In the third study we investigated at which level ADA inhibition interfered with the 
immune response. In vitro experiments with human T cells showed that early events in T cell activation were most sensitive to $2^{\prime} \mathrm{dcf}$ and $\mathrm{AdR}$. However, apart from the activation process of $\mathrm{T}$ cells, $2^{\prime} \mathrm{dcf}$ and $\mathrm{AdR}$ interfered also with proliferation of activated $T$ cells, although higher concentrations were necessary to induce this effect. Proliferation of activated $T$ cells was inhibited by interference with IL 2 production and IL 2 receptor expression. In contrast to the in vivo experiments, in vitro experiments showed that $2^{\prime} \mathrm{dcf}$ alone had no inhibitory effect on the immune response and AdR had to be added to the cultures to observe the effects mentioned above. This observation, which is in concordance with others(96-98), strongly suggests that in vivo the interaction between lymphoid tissue and circulating levels of adenosine and deoxyadenosine is of importance in the genesis of the immunosuppressive state induced. Selective trapping of AdR by lymphoid tissues, as proposed by Carson (84), may represent a mechanism that brings about this interaction. The biological mode of action of ADA inhibition resembles the action of well known immunosuppressive drugs such as cyclosporin $\mathrm{A}$ and steroids. These drugs have also shown to interfere with $T$ cellular immune response either by inhibition of $T$ cell activation or inhibition of lymphokine production. During $2^{\prime}$ dcf and AdR treatment both $T$ cell activation and lymphokine production were inhibited. Concerning the mode of action, it is of special interest that also proliferation of activated $\mathrm{T}$ cells could be inhibited by $2^{\prime} \mathrm{dcf}$ and $\mathrm{AdR}$, which means that the approach of ADA inhibition seems not only feasible to prevent rejection but can also be used to treat ongoing rejection.

It is concluded that interference with enzymatic reactions, more or less specific to lymphocytes, such as occurs during $2^{\prime}$ dcf treatment, is an effective way to induce immunosuppression. The major advantage of this kind of treatment, over traditional immunosuppressive treatment with steroids and azathioprine, is determined by its lymphospecificity.

In man, $2^{\prime} \mathrm{dcf}$ is used in patients with lymphoproliferative malignancies(99). In these patients low doses of $2^{\prime} \mathrm{dcf}$, which showed therapeutic effect, were safe and tolerable. At high doses, neurotoxicity and nephrotoxicity were observed, the latter mostly in patients with prior renal impairment. In these patients with large tumor loads, tumor degradation products inevitably played an important role in the toxic effects described. However, less is known about the toxic effect of the drug in noncancer patients and further investigations are necessary to determine the safety of $2^{\prime}$ def as an immunosuppressive agent.

\subsection{Selective immunosuppression by local treatment of the allograft}

So far immunosuppressive therapy after organ transplantation consists of systemic inhibition of the immune response. Recently however, controversy has increased concerning the role of systemic versus local regulatory mechanisms in cellular im- 
mune response(21,22). Immune stimulation by $\mathrm{MHC}$ antigen expression has been seen as a local as well as a systemic process in both allograft rejection and autoimmune disease(100-106). The same controversy holds true for the effector mechanisms during cellular immune response $(21,22,24,28,107,108)$. If however, local regulatory mechanisms within the graft are of major importance during the rejection response, the allograft would be a favourable subject for local immunosuppressive therapy. In this way allograft survival could be induced by local immunosuppression within the graft while systemic side effects of immunosuppressive therapy are avoided. In this thesis it is investigated whether indeed local treatment of allograft rejection is an effective approach to induce selective immunosuppression.

\subsubsection{Immunological aspects of local treatment}

Initially, it was studied whether local treatment of the allograft resulted in effective immunosuppression and hence prolongation of graft survival. Next, investigations were directed to the mechanisms by which local immunosuppression interfered with the rejection response.

In study 4 and 5 local immunosuppression was induced in rat renal allografts by local delivery of prednisolone into the renal artery of the transplanted kidney. The drug was given for 13 days via a catheter into the suprarenal artery. The technique itself showed no detrimental or enhancing effects on renal allograft survival. Intrarenal administration of prednisolone appeared to be superior to any other way of drug administration. A low dose of $4 \mathrm{mg} / \mathrm{kg} /$ day, given by continuous intrarenal infusion, resulted in significant prolongation of graft survival whereas continuous systemic administration of this dose was not effective. In order to induce prolongation of graft survival during systemic administration the dose had at least to be doubled. Intrarenal prednisolone delivery $(4 \mathrm{mg} / \mathrm{kg} /$ day) resulted in kidney prednisolone levels twice as high as during systemic administration of the drug whereas systemic drug levels during both ways of administration were comparable. These findings indicate that local drug levels within the graft were responsible for the immunosuppressive effect obtained during local graft treatment. Immunohistological studies indicated that during intrarenal drug delivery systemic responsiveness to the renal allograft was normal since, except for a somewhat lower percentage of macrophages, cellular infiltration in the intrarenal treated grafts was comparable to that in the untreated grafts. However, T cells and macrophages present in the intrarenal treated grafts were not able to destroy grafted tissue. Compared to untreated or systemically treated grafts local immunosuppressive therapy resulted in inhibition of IL 2 receptor expression, absence of IFN- $\gamma$ within the graft and prevention of MHC class II induction on grafted tissue. In conclusion, these data demonstrate that local prednisolone levels within the graft can result in effective immunosuppression. Moreover, the data indicate the presence of local regulatory mechanisms in graft rejection. 
To further strengthen the evidence for the efficacy of local graft treatment a special heart transplantation model was used in study 6 . In this model systemic blood llevels of the immunosuppressive drug could be minimized by transplanting cardiac allografts in such way that venous blood flow from the graft directly entered the liver of the recipient via an anastomosis between the graft and the portal vein. Local immunosuppression was induced by infusion of the steroid budesonide directly into the artery supplying the cardiac allograft. The steroid budesonide is rapidly cleared by the liver which means that the pharmacological properties of the drug in combination with the characteristics of the transplantation model made it possible to measure accurately the effect of local immunosuppression. Local administration of budesonide resulted in significant prolongation of allograft survival while systemic drug levels were so low that systemic biological effects of the drug during local administration were not measurable. In contrast, however, systemic dellivery of the same dosage resulted in significant systemic side effects such as reduction of body weight, spleen weight, thymus weight and adrenal weight.

The data obtained in the studies mentioned above clearly demonstrate that local treatment of the graft is an effective way to induce selective immunosuppression. Our findings are in agreement with those studies advocating a central rolle of local regulatory mechanisms during allograft rejection(24,28,101,102,106-108). For example, it was demonstrated that CTL could mature in sponge matrix allografts independent of the host systemic immune response from day 5 after transplantation(28). Moreover, it was reported that local administration of IFN- $\gamma$ induces local expression of MHC class II antigens on surrounded tissue(109), which is in accordance with our observation that during local steroid treatment the absence of IFN- $\gamma$ within the graft is associated with the absence of MHC class 11 antigens on grafted tissue. This last observation stimulated us to study in more detail the effect of steroids on the regulation of MHC class II antigens on non-immunological cells (study 7 ).

For this purpose, MHC class II inducing factors, including IFN- $\gamma$, were incubated in vitro with several human non-immunological cells such as umbilical venous endothelial cells, kidney epithelial cells, fibroblasts and human colon tumor cells, either in the presence or absence of prednisolone. Prednisolone at clinically relevant concentrations had no effect on the induction of MHC class II antigens on these non-immunological cell types. The induction of MHC class II antigens, by primary MLC supernatants or recombinant IFN- $\gamma$, was comparable with or without prednisolone present during the incubation period. However, when the drug was added to primary MLC at the initiation of culture, and supernatants were subsequently tested for MHC class II inducing capacity, supernatants harvested from cells cultured in the presence of prednisolone were not able to induce MHC class II antigens on non-immunological cells, in contrast to those supernatants made in the absence of prednisolone which strongly induced MHC class $I I$ antigens. In our experiments, as well as in renal transplant patients(106), successful steroid treatment was associated with the absence of MHC class II antigens on grafted tissue. The data described above show that this phenomenon has to be explained by the effect of the drug on 
the production of those factors responsible for MHC class II induction, while a direct effect of the drug on the grafted tissue is most unlikely. This finding extends earlier observations that steroids interfere with cytokine and lymphokine production(34-39).

In study 8 it was investigated to what extent infiltrating cells proliferate at the site of the allograft and whether proliferative behaviour is changed during immunosuppressive therapy. For this purpose a $5^{\prime}$ bromodeoxyuridine labeling technique was introduced(110), which allows the accurate detection of both proliferative activity and phenotypic characterization of cellular infiltrates within the allograft. Both $T$ helper and suppressor/cytotoxic $\mathrm{T}$ cells showed substantial proliferative activity within untreated rat cardiac allografts. In contrast, macrophages hardly showed proliferative activity. In addition to the sponge matrix experiments performed by others, which showed proliferation of cytotoxic T cells within the graft(28), we were able to detect also proliferation of $\mathrm{T}$ helper cells within the graft, which supports the link between DTH and allograft rejection as suggested by others(21,111-113). During systemic treatment with the steroid budesonide still a remarkable amount of proliferative cells was observed within the grafts although signs of graft destruction were absent. In the treated grafts, overall cellular infiltration was lower compared to the untreated grafts, however, the percentage of $T$ helper cells and suppressor/cytotoxic $T$ cells that showed proliferation was comparable in the untreated and treated animals. Cellular infiltration during effective immunosuppressive therapy was also observed by others(106,114-116). The fact, however, that the infiltrating cells also showed proliferative activity during treatment, while signs of graft destruction were absent, is striking. This finding questions the importance of the antiproliferative effect of steroids, as described extensively in vitro( $33,117,118)$. In contrast, it suggests the importance of other immunosuppressive effects of the drug, such as the inhibitory effect on the production of lymphokines and cytokines $(33-39,119)$ which may both play an essential role in mediating tissue destruction $(21,120)$.

From the studies in the second part of this thesis it is concluded that inhibition of the local immune response within the graft by local immunosuppressive treatment is an effective way to induce selective immunosuppression and represents a potentially important way to manipulate the immune response in organ transplantation.

\subsubsection{Pharmacological and therapeutic aspects of local treatment}

So far, it has been demonstrated that allograft rejection can be treated locally. Moreover, it was shown that local immunosuppression can reduce systemic side effects while treatment of the target organ, the allograft, still remains optimal. In this paragraph the application of local immunosuppressive therapy in organ transplantation will be further discussed. 
Localized drug delivery and local treatment has already, in several forms and for various diseases, become common practice in daily medical care. The existence of topical antibiotics or local nasal decongestants is well known. Especially several inflammatory processes, localized to a certain area of the body, proved suitable for local treatment. For example, inflammatory skin disease, asthma, rhinitis, joint disease and chronic inflammatory bowel disease are, amongst others, treated by topical steroid administration, either by ointments, aerosols, local injections or enemas. However, in all of these examples the specific target tissue is reached with relative ease, which will be generally not the case in vascularized allografts. Before, however, evaluating the way by which immunosuppressive drugs could be administered locally to vascularized allografts, it is worthwhile to consider how to define selectivity during local immunosuppressive therapy. In fact, it will be discussed that there are two approaches to take advantage of local delivery of immunosuppressive drugs to the allograft.

Generally, advantage of local drug delivery compared to systemic drug delivery is related to the ratio of the concentrations (locally or systemically) during local and systemic drug administration(121,122). Accordingly, the advantage of local drug delivery can be classified as regional or systemic. Regional advantage can be defined as the gain in drug concentration at the target organ (e.g. the graft) following local over systemic drug administration. Regional advantage of local drug delivery was obtained in the kidney transplantation model. During local prednisolone delivery, drug levels within the graft were twice as high as during systemic drug delivery while systemic drug levels were comparable. The regional advantage achieved by local administration could be applied to lower the dose of prednisolone during local delivery, as compared to systemic delivery, without losing immunosuppressive effect. In contrast to regional advantage, systemic advantage can be reached during local drug delivery; which means a reduction in systemic drug concentration following local over systemic drug delivery. Systemic advantage after local drug delivery is obtained if the drug is rapidly cleared by the target organ to which it is delivered or shortly thereafter. Systemic advantage was reached in the lveart transplantation model in which budesonide was rapidly cleared by the liver shortly after it was infused into the target organ, the transplanted heart. Compared with systemic budesonide administration this approach resulted in low systemic drug levels and hence systemic advantage.

Regarding local immunosuppressive therapy several options exist by which an immunosuppressive drug, suitable for local application, can be delivered to the graft (target tissue). In this thesis local immunosuppression was induced by continuous infusion of the drug into the artery supplying the graft. In this model advantage of local immunosuppressive therapy can, among others, be expected when the immunosuppressive drug, which is locally delivered, is cleared by the graft or shortly thereafter. This approach, mainly leading to systemic advantage, is applicable to kidney and liver transplants, since both organs possess clearing capacities. When the immunosuppressive drug infused into the artery supplying the graft is not cleared 
by the graft, local drug delivery can still be of advantage (regional) when the systemic clearance of the drug is high and the blood flow through the target organ (graft) is low $(121,122)$. Since blood flow through rejecting allografts decreases significantly, this approach would be applicable to anti-rejection therapy. In 1969 Kountz(123) and later Laupacis(124), already demonstrated excellent graft survival rates in renal transplant patients treated with intrarenal delivery of methylprednisolone over a short period of time immediately after transplantation or during rejection episodes. However, intra-arterial infusion of the drug into the graft showed serious drawbacks, such as infection and thrombosis which both limited clinical application. Nowadays, however, local intra-arterial drug delivery to the graft may become clinically applicable by means of intra-arterial biocompatible catheters and programmable implantable infusion pumps. Depending, however, on the site of the graft and the pharmacokinetic properties of the drug also other routes of drug administration may be used to induce local treatment. For example, oral administration and aerosols may be applicable in respectively liver and lung transplants.

Besides the possibilities mentioned above, several drug targeting systems are under investigation at the moment. For organ transplants site specific drug delivery via pro-drugs may be an attractive approach to induce local immunosuppression $(122,125,126)$. Pro-drugs are agents which must undergo biotransformation prior to exerting their pharmacological effects. Taking advantage of unique characteristics of cells or tissues, it is possible to design pro-drugs which are cell or tissue specific(125). According to these principles, drugs can be developed (pro-drugs) which are by themselves inactive, but within the specific organ e.g. kidney or liver they undergo change into the active drug, for example by local enzymatic reactions highly specific for the organ. When the active compound fulfils certain criteria, such as a high clearance by the target organ or shortly thereafter, this approach can result in high local drug levels and low systemic drug levels. According to the results presented in this thesis, the development of immunosuppressive pro-drugs which permit localized immunosuppression of certain defined grafts e.g. kidney or liver would open new perspectives in immunosuppressive therapy. 


\section{Summary}

In the last decade potent immunosuppressive drugs have been introduced in the field of organ transplantation and graft survival rates improved concomitantly. However, the therapeutic index of many immunosuppressive agents presently used is low and systemic side effects of the drugs are still a major impediment to successful therapy. Hence, attempts should be made to improve selectivity of immunosuppressive therapy. In this thesis different approaches are investigated to induce more selective immunosuppression after organ transplantation.

In the first two chapters of this thesis an overview is given of the immunobiological aspects of transplantation and the immunosuppressive therapy currently used. In summary, it is concluded that the rejection process includes contributions from all the major elements of the immune system. Immunosuppressive drugs all interfere with one or several steps of the immune reaction and in this way prevent or suppress rejection. Specific actions and side effects of several immunosuppressive agents are discussed, amongst them are azathioprine, steroids, cyclosporin A, ATG and monoclonal antibodies.

Chapter three gives an introduction to and discussion of the experimental work. In the thesis two different approaches to induce selective immunosuppression are presented. The first part of the thesis concerns the induction of selective immunosuppression by means of interference with enzymatic reactions within lymphocytes. The second part, concerns selective immunosuppression by means of local immunosuppressive treatment of the graft.

Studies 1-3 deal with selective immunosuppression by interference with enzymatic reactions within lymphocytes. It has been shown by others that congenital deficiency of the enzyme adenosine deaminase (ADA) is strongly associated with severe combined immunodeficiency disease. The disease is almost restricted to the lymphoid tissue with minor impairment of other tissues. Hence, inhibition of the enzyme ADA after organ transplantation may be an attractive approach to induce immunosuppression. The agent $2^{\prime}$ deoxycoformycin $\left(2^{\prime} \mathrm{dcf}\right)$ is an extremely tightly binding inhibitor of ADA. The drug would provide therefore the possibility to induce selective impairment of lymphocyte function and hence selective immunosuppression. Study 1 shows that continuous infusion of $2^{\prime} \mathrm{dcf}$ results in complete suppression of skin allograft rejection in rats. $2^{\prime} \mathrm{dcf}$ preferentially affected lymphocyte function while neutrophils seemed resistent to the drug. In study 2 it is demonstrated that in a rat skin transplantation model the potency of $2^{\prime} \mathrm{dcf}$ is comparable to that of cyclosporin $\mathrm{A}$, which leads to the conclusion that in rats $2^{\prime} \mathrm{dcf}$ is a strong immunosuppressive drug. The effect of $2^{\prime} \mathrm{dcf}$ and deoxyadenosine (AdR) on human $T$ cell function is investigated in study 3 . It is demonstrated that $2^{\prime} \mathrm{dcf}$ and $\mathrm{AdR}$ interfere with several steps in $T$ cellular immune response, such as cell activation, 
IL 2 production and IL 2 receptor expression. According to these results it is concluded that inhibition of the enzyme ADA is an attractive approach to induce immunosuppression. However, further investigations are necessary to determine the safety of 2 "dcf as an immunosuppressive agent.

The second part of this thesis (studies 4-8) reports on selective immunosuppression by means of local treatment of the allograft. In study 4, various ways of prednisolone administration are tested in a rat kidney transplantation model. Local delivery of the drug directly into the renal artery of the graft proved superior to any other way of drug administration. At a low dose of $4 \mathrm{mg} / \mathrm{kg} /$ body weight per day, continuous intrarenal infusion of the drug resulted in significant prolongation of graft survival whereas during systemic administration of the drug, the dose had at least to be doubled to observe an effect on graft survival. In study 5 it is demonstrated that local prednisolone levels within the kidney allograft were responsible for the immunosuppressive effect observed during local treatment. At the dose of 4 $\mathrm{mg} / \mathrm{kg} /$ body weight per day, local prednisolone administration resulted in drug levels within the graft that were twice as high as during systemic drug delivery whereas systemic drug levels in both groups were comparable. During intrarenal delivery, systemic responsiveness to the renal allograft proved normal since intrarenal treated grafts were infiltrated by MHC class II positive host cells. However, within the graft, intrarenal prednisolone levels interfered with IL 2 receptor expression, $\mathbb{E F N}-\gamma$ production and MHC class II induction on grafted tissue. In this way T cells and macrophages present within the intrarenal treated grafts were not able to mediate graft destruction. These results demonstrate that local drug levels within the graft contribute significantly to effective inhibition of cellular immune response in allograft rejection. Study 6 was performed to determine more precisely the potency of local immunosuppressive therapy alone. In a special heart transplantation model it was demonstrated that local graft treatment with the topical steroid budesonide resulted in significant prolongation of graft survival while systemic drug levels were so low that signs of systemic immunosuppression were not measurable. These results demonstrate that allograft rejection can be treated locally without significant systemic immunosuppression. From studies 4-6 it is concluded that selective immunosuppression by local treatment of the graft is an effective and attractive way to induce immunosuppression.

Study 7 describes the effect of steroids on the regulation of MHC class II expression on human non-lymphoid tissue. It is shown that steroids inhibit the production of those factors responsible for the induction of MHC class II antigens on nonlymphoid cells. However, once these factors are present, steroids do not affect the induction process of MHC class II antigens on these cells.

Study 8 was performed to determine cellular proliferation at the site of the allograft in the absence and presence of immunosuppressive therapy. In the untreated renal allografts it was shown that $T$ cytotoxic/suppressor cells as well as $T$ helper cells clearly proliferate at the site of the graft. During effective systemic immunosuppressive therapy with the steroid budesonide cellular proliferation at the site of the graft 
was not affected whereas signs of graft destruction were absent. Concerning the action of steroids, this observation questions the importance of the anti-proliferative effect of steroids as described in vitro. In contrast, it strongly suggests the importance of other immunosuppressive effects of steroids which prevent the destruction of the graft.

The main conclusion from the second part of this thesis is that graft rejection can effectively be treated by local immunosuppressive therapy. Since this approach offers an attractive way to induce selective immunosuppression, special attention is paid to the clinical application of local immunosuppressive therapy. In the final part of the discussion, the pharmacological and therapeutic aspects of local graft treatment are discussed and suggestions are made for clinical application. 

In de laatste jaren heeft de introductie van meer effectieve immunosuppressiva geleid tot een aanzienlijke verbetering van de transplantaatoverleving. De therapeutische index van de huidige immunosuppressiva is echter nog laag en systemische bijwerkingen vormen regelmatig een beperking in het klinisch gebruik.

In dit proefschrift worden twee verschillende benaderingen onderzocht waarmee de selectiviteit van immunosuppressie bij orgaantransplantatie kan worden verhoogd. In hoofdstuk II en II van het proefschrift wordt een overzicht gegeven van de bij orgaantransplantatie belangrijke immunologische aspecten en de wijze waarop afstoting kan worden onderdrukt. De specifieke werking en klinische toepassing van de verschillende immunosuppressiva wordt nader besproken.

In hoofdstuk III wordt het experimentele werk ingeleid en beschreven. In het eerste gedeelte van het proefschrift is onderzocht op welke wijze selectieve immunosuppressie kan worden geïnduceerd door interactie met enzymatische reacties welke min of meer specifiek zijn voor lymfocyten. In het tweede gedeelte van het proefschrift. is onderzocht in hoeverre onderdrukking van de locale immuunrespons in het transplantaat kan leiden tot effectieve en selectieve immunosuppressie.

In de studies 1-3 wordt het immunosuppressieve effect dat kan worden bereikt door interactie met enzymatische reacties binnen de lymfocytpopulatie nader uitgewerkt. Het is bekend dat congenitale deficiëntie van het enzym adenosine deaminase kan leiden tot ernstige vormen van immuundeficiëntie. In de eerste twee studies is onderzocht in hoeverre remming van dit enzym, met behulp van het geneesmiddel $2^{\prime}$ deoxycoformycin ( $2^{\prime} \mathrm{dcf}$ ), kan leiden tot effectieve immunosuppressie bij orgaantransplantatie. In studie 1 wordt aangetoond dat bij de rat de afstoting van huidtransplantaten volledig kan worden onderdrukt door continue infusie van $2^{\prime} \mathrm{dcf}$. Behandeling met $2^{\prime} \mathrm{dcf}$ resulteert voornamelijk in lymfopenie terwijl neutrofielen resistent lijken te zijn voor $2^{\prime}$ dcf. In studie 2 wordt het immunosuppressieve effect van $2^{\prime}$ dcf vergeleken met het immunosuppressieve effect van cyclosporine. Bij de rat geven beide middelen een gelijke overleving van huidtransplantaten. In studie 3 wordt de werking van $2^{t} \mathrm{dcf}$ en deoxyadenosine op humane $\mathrm{T}$ cellen nader geanalyseerd. $2^{\prime}$ Deoxycoformycin en deoxyadenosine blijken, in vitro, te interfereren met $T$ ce】 activatie, IL 2 productie, en IL 2 receptor expressie. Naar aanleiding van de gegevens verkregen uit studie 1-3 wordt geconcludeerd dat remming van het enzym adenosine deaminase een aantrekkelijke benadering vormt voor de inductie van selectieve immunosuppressie na orgaantransplantatie. De klinische toepassing van deze benadering verdient nadere studie.

In het tweede gedeelte van dit proefschrift (studie 4-8) wordt onderzocht of de inductie van locale immunosuppressie in het transplantaat kan leiden tot effectieve onderdrukking van de rejectierespons. De selectieve immunosuppressie die door mid- 
del van locale transplantaatbehandeling wordt verkregen, heeft tot doel systemische bijwerkingen van immunosuppressieve therapie te voorkomen. In studie 4 worden verschillende toedieningsvormen van prednisolon getest in een niertransplantatiemodel bij de rat. Locale toediening van prednisolon direct in de aanvoerende arterie van het transplantaat blijkt de meest effectieve toedieningsvorm. Bij locale toediening kan de dosis worden gehalveerd ten opzichte van systemische toediening zonder dat verlies optreedt aan immunosuppressief effect. In studie 5 wordt de werking wan locale toediening van prednisolon nader geanalyseerd. Locale prednisolon spiegels in het transplantaat blijken verantwoordelijk voor het immunosuppressief effect tijdens locale behandeling. Gedurende locale therapie lijkt de systemische immuunrespons tegen het transplantaat niet beinvloed. Niertransplantaten die locaal behandeld zijn vertonen microscopisch duidelijk cellulaire infiltraten. Echter tijdens locale behandeling interfereert de locale prednisolon spiegel in het transplantaat met de productie van interferon-gamma, de expressie van IL2 receptor en de inductie van MHC klasse II antigenen op getransplanteerd weefsel. Op deze wijze blijken de infiltrerende cellen niet in staat de rejectierespons te effectueren en weefsel destructie te bewerkstelligen.

Studie 6 heeft tot doel de effectiviteit van locale immunosuppressie nader te preciseren. Hierbij werd gebruik gemaakt van een speciaal harttransplantatiemodel bij de rat. Harten werden getransplanteerd met de veneuze afvloed op de vena porta en locale immunosuppressie werd geïnduceerd door locale toediening van het steroïd budesonide in de aanvoerende arterie van het transplantaat. Budesonide wordt o.a. gekenmerkt door een hoge klaring in de lever en locale toediening in het genoemde tranplantatiemodel resulteert in hoge budesonide spiegels in het transplantaat gecombineerd met extreem lage systemische spiegels. De systemische spiegels blijken zo laag dat systemische bijwerkingen van budesonide niet kumnen worden aangetoond. Localle toediening resulteert echter in effectieve immunosuppressie en de transplantaatoverleving is vergelijkbaar met de transplantaatoverleving in dieren die systernisch met budesonide worden behandeld.

Naar aanleiding van de resultaten verkregen uit studie 4-6 wordt geconcludeerd dat transplantaatafstoting locaal kan worden behandeld en dat deze benadering een effectieve manier vormt voor de inductie van selectieve immunosuppressie.

In studie 7 wordt aandacht besteed aan het effect van steroïden op de regulatie van MHC klasse II antigenen op humane niet lymfoïde cellen. De experimenten in deze studie tonen aan dat prednisolon de productie remt van die stoffen (bijv. interferongamma) die verantwoordelijk zijn voor de inductie van MHC klasse II antigenen op niet lymfoïde cellen. Het inductieproces zelf daarentegen wordt niet beinvloed door prednisolon.

In studie 8 wordt onderzocht in hoeverre infiltrerende cellen prolifereren in het transplantaat en de mate waarin proliferatie wordt beinvloed door immunosuppressieve therapie. Uit de experimenten blijkt dat zowel T cytotoxische/suppressor cellen als $\mathrm{T}$ helper cellen prolifereren in het transplantaat. Effectieve systemische immunosuppressie met budesonide heeft weinig invloed op het proliferatieve karakter 
van de infiltrerende cellen; dit terwij weefseldestructie en transplantaatafstoting tijdens therapie niet optreden. Deze bevinding suggereert het belang van de remmende werking van sterö̈den,zoals budesonide, op de productie van lymfokinen welke een rol spelen bij de inductie van weefseldestructie.

Uit de resultaten beschreven in het tweede gedeelte van dit proefschrift wordt geconcludeerd dat locale onderdrukking van de immuunrespons in het transplantaat leidt tot effectieve immunosuppressie. Met name locale inhibitie van lymfokine productie lijkt hierbij van belang. Aangezien locale transplantaatbehandeling een attractieve manier vormt voor de inductie van selectieve immunosuppressie wordt in de discussie aandacht besteed aan de farmacologische en therapeutische aspecten van locale transplantaatbehandeling en de klinische toepassing hiervan. 


\section{References Chapter I-III}

1. Carpenter $\mathrm{CB}$, Immunobiology of transplantation pp 49-72. In: renal transplantation. Edited by MR. Garovoy and RD. Guttmann, Churchill Livingstone 1986.

2. Daar AS, Fuggle SV, Fabre JW, Ting A, Morris PJ. The detailed distribution of MHC class II antigens in uormal human organs. Transplantation 1984:38:293.

3. Stukart MJ, H-2 regulation of T cell immunity against moloney leukemia virus. Thesis MJ Stukart 1983, Amsterdam.

4. Unanue ER, Beller DJ, Lu Cy, Allen PM. Antigen presentation: comments on its regulation and mechanism. J Immunol 1984;132:1.

5. Hunsicker LG. Place of HLA matching in clinical transplantation. pp $28-48$ In: renal transplantation. Edited by MR. Garovoy and RD. Guttmann, Churchill Livingstone 1986.

6. Ting A, Morris PJ. Piowerful effect of HLA-Dr matching on survival of cadaveric renal allografts. Lancet $1980 ; 2: 282$.

7. Goeken NE, Thompson JS, Corry RJ. A 2-year trial of prospective HLA-Dr matching. Transplantation 1981;32:522.

8. Strom TB, Kupiec-Weglinski JW, Tilney NL. On the mechanisms of rejection of vascularized organ allografts: a review and an attempt at synthesis. pp 126-146 In: progress in transplantation, volume 2. Edited by PJ. Morris and NL. Tilney, Churchill Livingstone 1985.

9. Moore RN, Oppenheim JJ, Farrar JJ, Carter CS, Waheed A, Shadduck RK. Production of LAF (IL 1) by macrophages activated with colony stimulating factors. J Inmunol 1980;125:1302.

10. Mizel SB. Interleukin I and T cell activation. Immunol Rev 1982;63:51.

11. Gillis S, Mizel SB. T cell Lymphoma model for analysis of interleukin 1 mediated T cell activation. Proc Natl Acad Sci 1981;78:1133.

12. Robb RJ, Munck A, Smith KA. T cell growth factor receptors quantification, specificity and biow logical relevance. J Exp Med 1981;154:1455.

13. Trobridge IS, Omary MB. Human cell surface glycoprotein related to cell proliferation is the receptor for transferrin. Proc Natl Acad Sci 1981;78:3039.

14. Helderman JH, Strom TB. Specific insulin binding site on $T$ and $B$ lymphocytes as a marker of cell activation. Nature 1978;174:62.

15. Durum SK, Gershon RK. Interleukin 1 can replace the requirement for I-A positive cells in the proliferation of antigen primed T cells. Proc Nat Acad Sci 1982;79:4747.

16. Gillis S, Mochizuki DY, Conlon PJ. Molecular characterization of interleukin 2. Immunol Rev $1982 ; 63: 167$.

17. Smith KA, Lachman LB, Oppenheim JJ, Favata MF. The functional relationship of the interleukins. J Exp Med 1980;151:1551.

18. Inaba $K$, Granelli-Piperno $G_{n}$ Steinmann $R M$. Dendritic cells induce T lymphocytes to release $B$ cell stimulating factors by an interleukin 2 dependent mechanism. $J$ Exp Med 1983;158:2040.

19. Pober JS, Gimbrone MA, Cotran RS, Reiss CS, Burakofr SJ, Fiers W, Ault KA. Ia expression by vascular endothelium is inducible by activated $T$ cells and human gamma-interferon. J Exp Med $1983 ; 157: 1339$.

20. Leszczynski L, Ferry B, Schellekens $H$, $v$ d Meide $\mathbf{P}$, Häyry P. Antagonistic effects of gammainterferon and steroids on tissue antigenicity. J Exp Med 1986;164:1470.

21. Intragraft rejection mechanisms. Immunol Rev 1984;77.

22. Häyry P. Intragraft events in allograft destruction. Transplantation $1984 ; 38: 1$.

23. Winn HJ. Antibody mediated rejection. pp 17-27. In: kidney transplant rejection, diagnosis and treatment. Edited by GM Willianns.s. JF Burdick and K Solez. Marcel Dekker inc. 1986.

24. Nemlander A, Soots A, von Willebrand $\mathbf{E}$, Häyry P. Redistribution of renal allografturesponding leucocytes during rejection. II. Kinetics and specificity. J Exp Med 1982;156:1087.

25. Hall BM, Dorsch SE. Cells mediating allograft rejection. Immunol Rev 1984;77:31.

26. Häyry $\mathrm{P}$, von Willebrand $\mathrm{E}$, Soots $\mathrm{A}$. In situ effector mechanisms in rat kidney allograft rejection. III. Kinetics of the inflammatory response and generation of donor directed killer cellls. Scand J Immunol 1979;10:95. 
27. Porter KA, Joseph NH., Rendell JM, Stolinski C, Moehn RJ, Calne RY. The role of lymphocytes in the rejection of canine renal homotransplants. Lab Invest 1969;13:1080.

28. Ascher NL, Chen $S$, Hof fman RA, Simmons RL. Maturation of cytotoxic T cells within sponge matrix allografts. J Immunol 1983;131:617.

29. Strom TB, Tilney NL, Paradysz JM, Bancewics J, Carpenter CB. Cellular components of allograft rejection; identity, specificity, and cylotoxic function of cells infiltrating acutely rejecting allografts. J Immunol 1977;118:2020.

30. Tilney NL, Strom TB. Chemical suppression of the immune responses. pp 1-31 In; Progress in transplantation, volume 3. Edited by PJ Morris, NL. Tilney, Churchill Livingstone 1986.

31. Bach JF, Strom TB. The mode of action of immunosuppressive agents. Research monographs in immunology, wolume 9, Elsevier 1985.

32. Amend WJC, Suthanthiran M, Gambertoglio JG. Immunosuppression following renal transplantation pp 73-92. In: Renal transplantation. Edited by MR Garovoy, RD Guttmann. Churchill Livingstone 1986.

33. Cupps TR, Fauci AS. Corticosteroid-mediated immunoregulation in man. Immunol Rev $1982 ; 65: 133$.

34. Dupont $\mathbf{E}$, Wyan $J$, Toussaint $C_{\text {. }}$ Glucocorticosteroids and organ transplantation. Transplantation 1984:37:331.

35. Dupont $\mathrm{E}$, Huygen $\mathrm{K}$, Schandené $\mathrm{L}$, Vandercruys $\mathrm{M}$, Palfliet $\mathrm{K}$, Wybran $\mathbb{J}$. Influence of in vivo immunosuppressive dirugs on production of lymphokines. Transplantation 1985;39:143.

36. Arya SK, Wong-Staal F, Gallo RC. Dexamethasone-mediated inhibition of human T cell growth factor and gamma-interferon mRNA. J Immunol 1984;133:273.

37. Snyder DS, Unanue ER. Conticosteroids inhibit murine macrophage la expression and interleukin 1 production. J Immunol 1982;129:1803.

38. Larsson EL. Cyclosporin A and dexamethasone suppress $\mathrm{T}$ cell responses by selectively acting at distinct sites of the triggering process. J Immunol $1980_{i} 124: 2828$.

39. Gillis $\mathrm{S}$, Crabtree GR, Smith KA. Glucocorticoid induced inhibition of $T$ cell growth factor production. I. The effect on mitogen induced lymphocyte proliferation. J Immunol 1979;123:16-24.

40. Warren MK, Vogel SN. Opposing effects of glucocorticosteroids on interferon-gamma induced murine macrophage Fic receptor and Ia antigen expression. J Immunol $1985 ; 134: 2462$.

41. Morris PJ, Chan L, French ME, Ting A. Low dose oral prednisolone in renal transplantation. Lancet $1982 ; 2: 525$.

42. Salaman JR, Griffin PJA, Price K. A controlled clinical trial of low dose prednisolone in renal transplantation. Transplant Proc 1982;14:103.

43. Buckels JAC, Mackintosh P, Barnes AD. Controlled trial of low versus high dose oral steroid therapy in 100 cadaveric renal transplants. Proceedings of the European Dialysis and Transplantation Association 1981;18:394.

44. Papadakis J, Brown CB, Cameron JS et. al. High versus low dose corticosteroids in recipients of

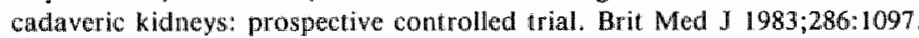

45. Eklund B, Ationen J, Häyry $\mathbf{P}$ et. al. Comparison of wo different imrnunosuppressive dosages of methylprednisolone in renal transplantation. Scan J Urol Nephrol 1981;64:179.

46. Chan $\mathrm{L}_{\mathrm{y}}$ French ME, Oliver DO, Morris PJ. High and low dose prednisolonie. Transplant Proc 1981;13:336.

47. Hess $A D$, Colombani $P M$, Esa A. Cyclosporine: Immuriobiologic aspects in transplantation pp 353-382. In: Kidney transplant rejection. Edited by GM Willams, JF Burdick, $K$ Solez. Marcel. Dekker ine 1986.

48. Granelli-Piperno A, Inaba K, Steiman R. Stimulation of lymphokine release from T lymphoblasts. Requirement for mRNA synthesis and inhibition by cyclosporin A. J Exp Med 1984;160:17-92.

49. Miyawaki T, Yachie A, Ohzeki S, Nagaoki T, Taniguchi N. Cyclosporin A does not prevent expres* sion of TAC antigen, a probable TCGF receptor molecule on mitogen stimulated human T cells. J Imnunol 1983;130:2737.

50. Wang HB, Heacock EH, Zheng CX, Tilney NL, Strom TB, Mannick JA. Evidence for the presence of suppressor T lymphocytes in animals treated with cyclosporin A. J Immunol 1982;128:1382.

51. Calne RY, Wood AJ. Cyclosporin in cadaveric renal transplantation: 3 year follow-up of a European Multicentre Trial. Lancet 1985;2:549.

52. The Canadian Multicenter Transplant Study Group. A randomized clinical triall of cyclosporine in cadaveric renal transplantation: Analysis at 3 years. New Engl J Med 1986;314:1219. 
53. Kahan BD. Cyclosporine: Biological activity and clinical applications. Grune and Stratton 1984.

54. Keown PA, Stiller CR, Wallace AC. Nephrotoxicity of Cyclosporin A. pp 423-458. In: Kidney tramsplant rejection. Edited by GM Williams; JF Burdick, K Solez. Marcel Dekker inc 1986.

55. Morris PJ, French ME, Dunnill MS et. al. A controlled trial of cyclosporine in renal transplantation with conversion to azathioprine and prednisolone after three month. Transplantation $1983 ; 36: 273$.

56. Rochet LL, Milford EL, Kirkman RL, Carpenter CB, Strom TB, Tilney NL. Conversion from cyclosporine to azathioprine in renal allograft recipients. Transplantation 1984;38:669.

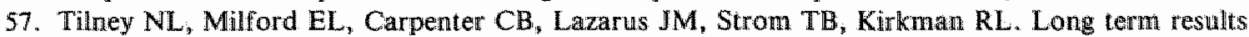
of cyclosporine treatment in renal transplantation. Transplant Proc 1986;18:179.

58. Woodruff MFA, Anderson NF. Effect of lymphocyte depletion by thoracie duct fistula and ad. ministration of antilymphocytic serum on the survival of skin homografts in rats. Nature $1963 ; 200: 702$.

59. Burdick JF. The biology of immunosuppression mediated by antilymphocyte antibodies. p307-334. In: Kidney transplant rejection. Edited by GM Williams, JF Burdick, K Solez. Marcel Dekker inc 1986.

60. Cosimi AB. Anti-lymphocyte globulin-- a final(?) look pl67-188. In: Progress in transplantation volume 2. Edited by PJ Morris, NL Tilney. Churchill Livingstone 1985.

61. Cosimi $A B$, Delmonico FL. Antilymphocyte antibody immunosuppressive therapy. p335-351. In: Kidney transplant rejection. Edited by GM Williams, JF Burdick, K Solez. Marcel Dekker inc 1986.

62. Maki T, Simpson M, Monaco AP. Development of suppressor T cells by antilymphocyte serum treatment in mice. Transplantation $1982 ; 34: 376$.

63. Sommer BG, Ferguson RM. Three inmediate postrenal transplant adjunct protocols combined with maintenance cyclosporine. Transplant Proc 1985;17:1235.

64. Filo RS, Smith EJ, Leapman SB. Reversal of acute allograft rejection with adjunctive ATG therapy. Transplant Proc 1981;13:4-82.

65. Hoitsma AJ, Reekers $\mathbb{P}$, Kreeftenberg JG, van Lier HJJ, Capel PJA, Koene RAP. Treatment of acute rejection of cadaveric renal allografts with rabbit antithymocyte globulin. Transplantation $1982 ; 33: 12$.

66. Kung $\mathrm{PC}$, Goldstein G, Reinherz EL, Schlossman SF. Monoclonal antibodies defining distinctiwe human T cell surface antigens. Science 1979:206:347.

67. Metzger H, The mechanism of action of antibodies. Mol. Immunol. 1984;21:679.

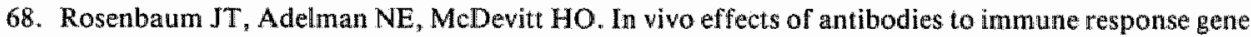
products. I. Haplotype-specific suppression of humoral immune responses with monoclonal antiIa. J Exp Med 1981;154:1694.

69. Kirkman RL, Barrett LV, Gaulton GN. The effect of anti-interleukin 2 receptor monoclonal antibodly on allograft rejection. Transplantation 1985;40:719.

70. FitzGerald DJP, Waldmann TA, Willingham MC, Pastan I. Pseudomonas exotoxin-anti-TAC. Cell specific immunotoxin active against cells expressing the human $T$ cell growth tactor receptor. $\mathrm{J}$ Clin Invest 1984;74:966.

71. Vallera DA, Quinones RR, Azemove SM, Soderling CCB. Monoclonal antibody-toxin conjugates reactive against human $T$ lymphocytes. A comparison of antibody linked to intact ricin toxin with antibody linked to ricin A chain. Transplantation 1984;37:3-87.

72. Vitteta ES, Uhr JW. The potential use of immunotoxins in transplantation, cancer therapy and immunoregulation. Transplantation $1984 ; 37: 535$.

73. Strom TB. New strategies for immunosuppression. Presented at The XII International Congress of the Transplantation Society, 1988, Sydney.

74. Thistlethwaite R, Cosimi AB, Delmonico FL. et.al. Evolving use of OKT3 monoclonal antibody for treatment of renal allograft rejection. Transplantation 1984;38:695.

75. Ortho Multicenter Transplant Study Group. A randomized trial of OKT3 monoclonal antibody for acute rejection of cadaveric renal transplants. N Engl J Med 1985;313:337.

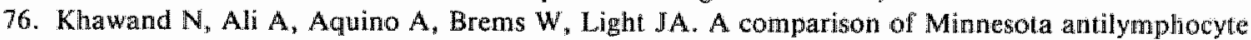
globulin (MAG) and OKT3 as initial therapy following cadaveric kidney transplantation. Presented at The XII International Congress of the Transplantation Sociely,1988, Sydney.

77. Rudnick S, Norman DJ, Kahana L, Shield CF, Stuart F, Monaco A, Goldstein G. A multicenter randomized study of the prophylactic use of OKT3 in kidney transplantation. Presented at The XII International Congress of the Transplantation Society, 1988, Sydney. 
78. Terasaki PU. Long term results of kidney transplantation. Presentied at The XII International Congiress of the Transplantation Society, 1988,Sydney.

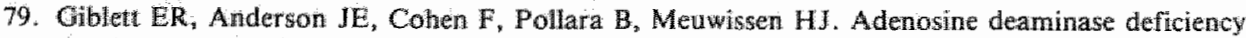
in two patients with severe impaired cellular inmunity. Lancet $1972 ; 2: 1067$.

80. Dissing J, Knudsen B. Adenosine deaminase deficiency and combined immunodeficiency syndrome. Lancet $1972 ; 2 \div 1316$.

81. Meuwissen HJ, Pollara B. Pickering RJ. Combined immunodeficiency disease associated with adenosine deaminase deficiency. J Pediatr 1975;86:169.

82. Thompson LF, Seegmiller JE. Adenosine deaminase deficiency and severe combined immunodeficiency disease. Adv Enzymol 1980;:51:167.

83. Mitchell BS; Kelley WN. Purinogenic immunodeficiency disease: clinical features and molecular mechanisms. Ann Intern Med 1.980;92:826.

84. Carson DA, Kay J, Seegmiller JE. Lymphospecific toxicity in adenosine deaminase deficiency and purine nucleoside phosphorylase deficiency: possible role of nucleoside kinase(s). Proc Natl Acad Sei $1977 ; 74: 5677$.

85. Wortmann RL, Mitchell BS, Edwards NL, Fox JH. Biochemical basis for differential deoxyadenow sine toxicity to ' $T$ and B lymphoblasts: role of 5-nucleotidase. Proc Natl Acad Sci 1979;76:2434.

86. Redelman D, Bluestein HG, Cohen AH, Depper JM, Wormsley S. Deoxyadenosine (AdR) inhibition of newly activated lymphocytes: Blockade at Go-Gi interface. J Immunol 1984;132:2030.

87. Uberti $\mathrm{J}, \mathrm{Lightbody} \mathrm{J} \mathrm{J}$, Johinson RM. The effect of nucleosides and deoxycoformycin on adenosine and deoxyadenosine inhibition of human lymphocyte activation. J Immunol $₫ 979 ; 123 ; 189$.

88. Mitchell BS, Mejias E, Daddona PE, Kelley WN. Purinogenic immunodeficiency disease: selective toxicity of cleoxyribonucleosides for "T cells. Proc Natl Acad Sci 1978; 75:5011.

89. Albert DA, Redelman D, Bluestein HG. Deoxyadenosine toxicity in human and mouse lymphocytes: similarities and contrasts. Fed Proc 1981;40:1081.

90. Carson DA, Kaye J, Seegmiller JE. Differential sensitivity of human leukemic T cell lines and B cell lines to growth inhibition by deoxyadenosine. J Immunol 1978;121:1726.

91. Scharenberg JGM. Purine metabolite mediated toxicity in human lymphoid cells; relevance for congenital immunodeficiency in man. Thesis, J Scharenberg, 1987, University of Utrecht, The Netherlands.

92. Agarwal RP, Spector T, Parks RE. Tightbindling inhibition of adenosine deaminase by various inhibitors. Biochem Plarmacol 1977;26:359.

93. Smyth JF, Young $\mathbb{R C}$, Young DM. In vivo toxicity to lymphoid tissue by 2 ' deaxycoformycin. Can Chem Pharmacol 1978;1:49.

94. Tedde A, Balis ME, Ikehara S, Pahwa R, Good RA, Trotta PP. Animal model for immune dysfunction associated with adenosine deaminase deficiency. Proc Natl Acad Sci 1980;77:4899.

95. Trotta PP, Tedde A, Ikehara $S$, Pahwa R, Good RA, Balis ME. Specific immunosuppressive effects of constant infusion of $2^{\prime}$ deoxycoformycin. Cancer Res 1981;41:2189.

96. Brox LW, Pollock E, Belch A. Adenosine and deoxyadenosine toxicity in colony assay systems for human T lymphocytes, B lymphocytes, and granulocytes. Can Chem Pharmacol 1982;9:49.

97. Howi "T, Smyth JF, Allison AC, Williams SC. Role of aclenosine deamirase in lymphocyte proliferation. Clin Exp Immunol $1976 ; 23: 395$.

98. Burridge PW, Paetkau V, Henderson JF. Studies of the relationship between adenosine deaminase and immune function. J Immunol 1977;119:675.

99. Annual report to the food and drug administration on deoxycoformycin and ARA-A. National Cancer Institute, October 1983.

100. Hanafusa T, Pujoll-Borell R, Chiovato L, Rusell RCG, Doniach D, Bottazzo GF. Aberrant expres* sion of HLA-Dr antigen on thyrocytes in Gritive's disease: relewance for auto-immunity, Iancet $1983 ; 2: 1111$.

101. de Waal RMW, Bogman MJJ, Maass $\mathrm{CN}_{n}$ Comelissen LMH, Tax WJM, Koene RAP. Variable expression of la antigens on vascular endothelium of mouse skin grafts. Nattere 1983;303:426.

102. Hatll BM, Bishop GA, Duggin GG, Horwath IS, Philips J, Tiller DJ. Increased expression of HLA. Dr antigens on renal tubular cells in renal transplants: relevance to the rejection response. Lancet $1984: 2: 247$.

103. Sobel RA, Blanchette BW, Bahn AK, Colvin RB. The immunopathology of experimental aillergic encephalomeylitis. II. Endothelial cell la increases prior to inflammatory cell infiltration. J Immunol 1984"132:2402. 
104. Wadgymar $\mathrm{A}$, Urmson $\mathrm{J}$, Baumal $\mathbf{R}$, Halloran $\mathbf{P F}$. Changes in la expression in mouse kidney during acute graft versus host disease. JImmunol 1984;132:1826.

105. Clarke Forbes RD, Parfrey NA, Gomersall M, Darden AG, Gutmann RD. Dendritic celllymphoid cell aggregation and major histocompatibility antigen expression during rat cardiac allograft rejection. I Exp Med 1986;164:1239.

106. Häyry $P$, von Willebrand $E$. The influence of the pattern of inflammation and administration of steroids on class II MHC antigen expression in renal transplants. Transplantation 1986;42:358.

107. Orosz $\mathrm{CG}, \operatorname{Zinn} \mathrm{NE}$, Sirinek L, Ferguson RM. In vivo mechanisms of alloreactivity. L. Frequency of donor-reactive cylotoxic T lymphocytes in sponge matrix allografts. Transplantation 1986:41:75.

108. Orosz CG, Zinn NE, Sirinek L, Ferguson RM. In vivo mechanisms of alloreactivity. II. Allospecificity of cytotoxic $T$ lymphocytes in sponge matrix allografts as determined by limiting dilution analysis. Transplantation 1986;41:84.

109. Nathan CF, Kaplan G, Levis WR et.al. Local and systemic effects of intradermal recombinant interferon-gamma in patients with lepromatous leprosy. $N$ Engl $J$ Med 1986;315:6.

110. Schutte B, Reynders MMJ, Bosman FT, Blijham GH. Studies with anti-bromodeoxyuridine antibodies. II Simultaneous immunocytochemical detection of antigen expression and DNA synthesis by in vivo labeling of mouse intestinal mucosa. J Histochem Cytochem 1987;35:371.

11. Loveland BE, Hogarth PM, Ceredig Rh, McKenzie IFC. Cells mediating graft rejection in mouse. 1. Lyt-1 cells mediate skin graft rejection. I Exp Med 1981; 153:1044.

112. Lowry RP, Gurley KE, Clarke Forbes RD. Immune mechanisms in organ allograft rejection. I. Delayed-type hypersensitiwity and lymphocytotoxicity in heart graft rejection. Transplantation $1983 ; 36: 391$.

113. Lowry RP, Marghesco DM, Blackburn JH. Immune mechanisms in organ allografit rejection. VI. Delayed-type hypersensitivity and lymphotoxin in experimental renal allograft rejection. Transplantation 1985;40:183.

114. Homan WP, Fabre JW, Williams KA, Millard PR, Morris PJ. Studies on the immunosuppressive properties of cyclosporin $A$ in rats receiving renal allografts. Transplantation 1980;29:361.

115. Homan WP, Fabre JW, Millard PR, Morris PJ. Effect of cyclosporin A upon second set rejection of rat renal allografts. Transplantation 1980;30:354.

116. Mason DW, Morris PJ. Inhibition of the accumulation in rat kidney allografts of specific but not non-specific-cytotoxic cells by cyclosporine. Transplantation 1984;37:46.

117. Roath S, Cuppari G. The effects of steroids on cultured lymphocytes. Clin Res 1965;13:542.

118. Rosenberg JC, Lysz K. Suppression of the immune response by steroids. Transplantation $1980 ; 29: 425$.

119. Waage A, Bakke O. Glucocorticosterouds suppress the production of tumor necrosis factor by lipopolysaccharide stimulated human monocytes. Immunology 1988:63:299.

120. Lowry RP, Blais D, Marghesco D, Powell WS. Immune effector mechanisms in organ allograft rejection. VIn: Inflammatory mediators and cytotoxins in rejecting rat cardiac allografts. Transplant Proc 1987;19:426.

121. Daemen $M$. Local drug administration: an experimental study on its possibilities and limitations. Thesis, M Daemen, 1987, University of Limburg, The Netherlands.

122. Smits JFM, Thijssen HHW. Spatial control of drug action: theoretical considerations on the pharmacokinetics of targetaimed drug delivery. In: Rate controlled drug administration and action. Edited by HAJ Struyker Boudier, CRC Press, 1986.

123. Kountz SL, Cohn R. Initial treatment of renal allografts with large intrarenal doges of immunosuppressive drags. Lancet 1969:1:338.

124. Laupacis A, Keown PA, Rankin RN, Gold R, Ulan RA, Stiller CR. Intravarterial methylprednisolone and heparin for the treatment of refractory renal transplant rejection episodes. Transplant Proc 1982;14:693.

125. Bundgaard H. Design of pro-drugs. Elsevier Science Publishers B. V. Amsterdam, 1985.

126. Orfowski M, Mizoguchi $H$, wilk S. N-acyl- $\gamma$-glutamyl derivatives of sulfamethoxazole as models of kidney selective prodrugs. I Pharmacol Exp Ther $1980 ; 212: 167$. 

Studies on selective immunosuppression by interference with enzymatic reactions within lymphocytes 



\section{The effect of 2'deoxycoformycin on skin allograft rejection in rats.}

Published in Transplantation 1985; 40: 137, entitled "Complete suppression of skin allograft rejection in rats treated with continuous infusion of 2 'deoxycoformycin".

\section{Summary}

Congenital deficiency of the enzyme adenosine deaminase (ADA) results in severe

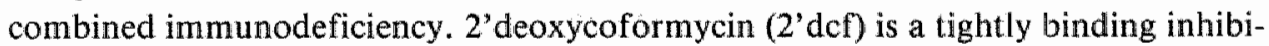
tor of $\mathrm{ADA}$, and the drug makes it possible to mimic a state of ADA deficiency. In this study we tested the immunosuppressive effect of 2 'dcf in a rat skin transplantation model.

Rats treated with continuous infusion of $2^{\prime} \mathrm{dcf}$ at doses of $0.3 \mathrm{mg} / \mathrm{kg}, 0.5 \mathrm{mg} / \mathrm{kg}$ and $0.7 \mathrm{mg} / \mathrm{kg}$ body weight per day (body wt/ day) showed significant prolongation

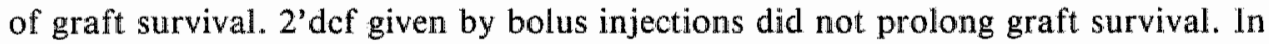
rats treated with continuous infusion of 2'dcf at a dose of $0.7 \mathrm{mg} / \mathrm{kg}$ body wt/day mean graft survival time (MST) after withdrawal of treatment was equal to MST in untreated animals, suggesting that during 2'dcf treatment allograft rejection was completely suppressed. In vitro, lymphocytes isolated from animals treated with continuous infusion of 2'dcf showed marked suppression of mitogen response. The 2 'dcf preferentially effects lymphocytes, but neutrophils seem resistent to the effect of the drug. The lymphocytotoxic effect of the drug is extreme; during therapy splenic weight decreased by allmost $50 \%$ and differential lymphocyte count in blood decreased from $85 \%$ to $17 \%$. Immunofluorescence studies showed that, within the spleen, the amount of $T$ cells and $B$ cells decreased markedly. Both $T$ cell subsets were affected, $\mathrm{OX} 8{ }^{+}$cells (suppressor/cytotoxic T cells) and $\mathrm{W} 3 / 25+$ cells (helper $\mathrm{T}$ cells). However $\mathrm{OX} 8^{+}$cells were more resistent to the drug than $\mathrm{W} 3 / 25^{+}$cells. Skin-grafted rats treated with $2^{\prime}$ dcf showed a strong decrease in the W3/25: OX8 ratio. In contrast, untreated rats showed a slight increase in the ratio after skin transplantation.

It is concluded that $2^{\prime} \mathrm{dcf}$ is a strong immunosuppressive drug in rats if given by continuous infusion. 


\section{Introduction}

One form of severe combined immunodeficiency is strongly associated with an inherited deficiency of the enzyme adenosine deaminase (ADA) (1-4). This enzyme catalyses the deamination of adenosine and deoxyadenosine to inosine and deoxyinosine respectively. ADA-deficient children show accumulation of adenosine and deoxyadenosine leading to $T$ cell dysfunction and to a variable loss of $B$ cell function $(3,4)$. The disease is almost restricted to the lymphoid tissues with relative minor impairment of other tissues. Considerable controversy exists concerning the biochemical mechanism that causes ADA deficiency to be lymphocytotoxic (5-9).

$2^{\prime}$ deoxycoformycin (2'dcf), a microbial fermentation product, is an extremely tightly binding inhibitor of ADA (10). This drug provides, therefore, the possibility of creating a metabolic state of ADA deficiency with specific impairment of lymphocyte function (11-13). Such manipulation of the purine metabolism that primarily appears to affect lymphocytes seems to be an attractive approach for immunosuppression. The influence of adenosine and deoxyadenosine on lymphocyte proliferation has been studied extensively in vitro $(14-17,18)$. Both agents appeared to inhibit T cell proliferation and, to a lesser extent, B cell proliferation. This effect was

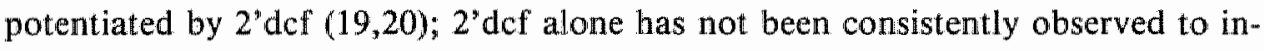
hibit lymphocyte proliferation in vitro (20-22).

Few in vivo studies have been performed on the immunosuppressive activity of 2 'dcf. Studies utilizing skin allografts and tumor test systems showed variable and marginal immunosuppressive activity of $2^{\prime} \mathrm{dcf}(10,23-25)$. $2^{\prime} \mathrm{dcf}$ given by single injections resulted in incomplete immunosuppressive activity that can be explained by the short half-life of the drug and rapid tissue dependent recovery of ADA. Given by continuous infusion, $2^{\prime} \mathrm{dcf}$ showed stronger immunosuppressive properties, as demonstrated by suppressed delayed-type hypersensitivity (DTH) reaction in mice (12).

In this study we examined the influence of continuously infused $2^{\prime} \mathrm{dcf}$ on skin allograft survival in rats. It is concluded that $2^{\prime} \mathrm{def}$ is a potent immunosuppressive drug in rats if given by continuous infusion.

\section{Materials and methods}

Animals. Inbred male Brown Norway $\left(\mathrm{RT}^{\mathrm{n}}\right)$ and Lewis rats $\left(\mathrm{RT}^{\mathrm{L}}\right)$ were obtained from the department of experimental animal services of the University of Limburg. Rats of 250 to $300 \mathrm{~g}$ were used for all experiments. Rats were supplied with acidified water and rat chow ad libitum.

Skin grafting. Full-thickness skin from the back of Brown Norway donor rats was grafted to the back of Lewis rats by the fitted graft technique. Grafts were covered by a plaster bandage for 8 days; after this time grafts were inspected daily and were 
considered to be rejected when complete necrosis of surface epithelium was observed.

Drug administration. Drug administration was started one day before skin grafting (day - 1) and lasted until day 12 posttransplant.

Single injections: Rats were daily injected intraperitoneally (ip) with 2 'def dissolved in $0.9 \% \mathrm{NaCl}$ at different concentrations. Solutions were prepared at day -1 , sterilized with a filter (pore size $0.2 \mu \mathrm{m}$ ), and kept at $37^{\circ} \mathrm{C}$, to permit comparison of results with those obtained with continuous infusion. The amount of $2^{\prime}$ 'dcf administered was adjusted to body weight of the recipient at day - 1 and remained constant during the experiment.

Continuous infusion: The 2'def was administered (ip) by an osmotic minipump (2ML2; Alzet, Palo Alto, CA) implanted in the abdominal cavity on day - 1. In this way 2 'dcf was infused at a constant rate of approximately $5.9 \mu \mathrm{l} / \mathrm{hr}$ from day - 1 until day 12. The 2'dcf was dissolved in $0.9 \% \mathrm{NaCl}$ and the doses were adjusted to body weight of the recipient at day -1 .

Lymphoid cell preparation. Animals were killed and the spleen was removed aseptically. Lymphoid cells were prepared by mincing the spleen, and the cells were gently passed through a sieve into RPMI $+0.4 \%$ bovine serum albumin (BSA) at $4^{\circ} \mathrm{C}$. Cells were washed and erythrocytes were removed by addition of hemolytic buffer for $3 \mathrm{~min}$ at $4^{\circ} \mathrm{C}$. Subsequently cells were washed twice in RPMI $+0.4 \%$ BSA. During the procedure cells were kept at $4^{\circ} \mathrm{C}$. Cell viability was $>95 \%$ by the trypan blue exclusion test.

Mitogen response. Mitogen-induced blastogenesis was determined by incorporation of tritiated thymidine ( $\left.{ }^{3} \mathrm{H}-\mathrm{TdR}\right)$. Lymphoid cells were cultured in microtiter plates at density of $5 \times 10^{5}$ cells per $\mathrm{ml}$ in $0.2 \mathrm{ml}$ of RPMI, containing $5 \times 10^{-5} \mathrm{M}$ 2-mercaptoethanol and $15 \%$ fetal calf serum (FCS). The mitogen concanavalin A (Con A) (Calbiochem-Behring Corp, La Jolla, CA) was used in an optimal concentration of $7.5 \mu \mathrm{g} / \mathrm{ml}$. Cells were incubated for $72 \mathrm{~h}$ in a humified atmosphere of $5 \%$ $\mathrm{CO} 2$ in air at $37^{\circ} \mathrm{C}$. ${ }^{3} \mathrm{H}$-TdR was present during the last $4 \mathrm{hr}$ of incubation. The cells were collected with a microharvester and ${ }^{3} \mathrm{H}-\mathrm{TdR}$ uptake was assayed by liquid scintillation.

Immunofluorescence. Spleen cells were suspended in RPMI $+0.4 \%$ BSA and placed at $37^{\circ} \mathrm{C}$ for 1 hour. Subsequently cells were washed twice in phosphatebuffered saline (PBS) $+0.4 \%$ BSA $+0.01 \%$ azide, and resuspended to a concentration of $5 \times 10^{6} \mathrm{cell} / \mathrm{ml}$. Cell viability was $>95 \%$ by trypan blue exclusion test. Cells were incubated with monoclonal antibodies at $4^{\circ} \mathrm{C}$ for half an hour and washed twice. Cells were then incubated with fluorescein isothiocyanate-labeled rabbit $\mathrm{Ig}$ antimouse Ig for $30 \mathrm{~min}$ at $4^{\circ} \mathrm{C}$. Cells were washed again and examined on a fluorescence-activated cell sorter (FACS) IV. The monoclonal antibodies used 
were $\mathrm{OX19}$, which binds to all $\mathrm{T}$ cells; W3/25 which recognizes helper $\mathrm{T}$ cells; $\mathrm{OX8}$ which binds to suppressor/cytotoxic T cells; and Mark I, a monoclonal antirat kappa light chain, used to enumerate B lymphocytes (26).

As control antibody we used MAS 037, a mouse IgM antibody against human fibronectin that does not bind to rat lymphoid cells.

The monoclonal antibodies OX19, OX8, W3/25, and MAS 037 were purchased from Seralab, West Sussex, England. Mark I was kindly provided by Dr. H. Bazin, experimental Immunology Unit, Faculty of Medicine, Louvain, Brussels.

\section{Results}

Skin graft survival. The effect of continuously infused 2'def on skin graft survival was studied and compared with allograft survival in animals that received $2^{\prime}$ def by ip bolus injections. The results are given in Table 1. Groups 3-6 consist of rats that received 2 'dcf by continuous infusion at different concentrations. Groups 7-8 are made up by animals treated with ip bolus injections at different concentrations once daily.

Control animals were untreated (group 1) or received a continuous infusion ip with saline (group 2). The osmotic minipump used to administer the saline appeared to have no influence on graft survival because MST in group 2 was equal to MST in group 1. Significant prolongation of graft survival was demonstrated in rats that received a continuous infusion of $2^{\text {' }} \mathrm{dcf}$ at doses of $0.7 \mathrm{mg} / \mathrm{kg}, 0.5 \mathrm{mg} / \mathrm{kg}$, and 0.3 $\mathrm{mg} / \mathrm{kg}$ body wt $/$ day. A dose of $0.1 \mathrm{mg} / \mathrm{kg}$ body wt $/$ day did not induce prolongation of graft survival.

2'dcf administered by continuous infusion at a dose of $0.7 \mathrm{mg} / \mathrm{kg}$ body wt/day resulted in complete suppression of rejection. In these animals the mean interval between withdrawal of treatment and rejection ( 8.3 days) closely equalled the mean survival time observed in untreated controls. When the dosage was reduced to 0.5 $\mathrm{mg} / \mathrm{kg}$ body $\mathrm{wt} / \mathrm{day}$, this interval shortened.

In rats treated with ip injections of $0.5 \mathrm{mg} / \mathrm{kg}$ and $1.5 \mathrm{mg} / \mathrm{kg}$ body weight once daily, graft survival was not prolonged, and grafts were rejected during therapy. Higher doses of 2'def given by ip bolus injections could not be tested because of shortage of the drug. However, if 2 'dcf has an immunosuppressive effect at higher doses it remains clear that the immunosuppressive effect of 2 'dcf is far more potent when administered by continuous infusion.

Mitogen response. Lymphocyte blastogenesis induced by mitogens is considered to reflect, at least in part, the function of immunocompetent cells in vivo. We examined the effect of the $T$ cell mitogen Con $A$ on splenic $T$ lymphocytes.

Animals were grafted and were untreated or received continuous infusion of 2 'def, $0.5 \mathrm{mg} / \mathrm{kg}$ body wt/day. Treatment started at day -1 and lasted till day 12 posttransplant. Rats were killed at various days after skin transplantation, and splenic lym- 
TABLE 1. Skin graft survival in $2^{\prime} \mathrm{dcf}$-treated rats ${ }^{\mathrm{a}}$

\begin{tabular}{|c|c|c|c|c|}
\hline $\begin{array}{l}\text { Experimental } \\
\text { group }\end{array}$ & Treatment & $\begin{array}{l}\text { Graft survival } \\
\text { (days) }\end{array}$ & $\begin{array}{l}\mathrm{MST} \pm \mathrm{SD}^{\mathrm{b}} \\
\text { (days) }\end{array}$ & $\begin{array}{l}\text { Mean interval } \\
\pm \mathrm{SD} \\
\text { between end } \\
\text { of treatment } \\
\text { and rejection } \\
\text { (days) }\end{array}$ \\
\hline 1 & - & $\begin{array}{l}9,9,9,9 \\
10,10,10\end{array}$ & $9.4 \pm 0.5$ & \\
\hline 2 & $\begin{array}{l}\text { Saline, } \\
\text { continuous infusion }\end{array}$ & $9,9,10,10$ & $9.5 \pm 0.6$ & \\
\hline 3 & $\begin{array}{l}0.1 \mathrm{mg} / \mathrm{kg} 2^{\prime} \mathrm{dcf}{ }^{\circ} \\
\text { continuous infusion }\end{array}$ & $\begin{array}{l}9,9,9,9,9,9 \\
10,10,10,13\end{array}$ & $9.7 \pm 1.3$ & \\
\hline 4 & $\begin{array}{l}0.3 \mathrm{mg} / \mathrm{kg} 2^{\prime} \mathrm{dcf} \\
\text { continuous infusion }\end{array}$ & $\begin{array}{l}11,11,11,11 \\
12,13,13,14\end{array}$ & $12.0 \pm 1.3^{\mathrm{d}}$ & \\
\hline 5 & $\begin{array}{l}0.5 \mathrm{mg} / \mathrm{kg} 2 \text { ' } \mathrm{dcf} \text {, } \\
\text { continuous infusion }\end{array}$ & $\begin{array}{l}14,15,15,16 \\
16,20,20,21\end{array}$ & $17.1 \pm 2.7^{d}$ & $5.1 \pm 2.7$ \\
\hline 6 & $\begin{array}{l}0.7 \mathrm{mg} / \mathrm{kg} 2 \text { dcf, } \\
\text { continuous infusion }\end{array}$ & $\begin{array}{l}18,19,19,20 \\
21,21,24\end{array}$ & $20.3 \pm 2.0^{\mathrm{d}}$ & $8.3 \pm 2.0$ \\
\hline 7 & $\begin{array}{l}0.5 \mathrm{mg} / \mathrm{kg} 2^{\prime \prime} \mathrm{dcf} \text {, } \\
\text { ip bolus }\end{array}$ & $\begin{array}{l}8,10,10,10 \\
11\end{array}$ & $9.8 \pm 1.1$ & \\
\hline 8 & $\begin{array}{l}1.5 \mathrm{mg} / \mathrm{kg} 2^{*} \mathrm{dcf} \text {, } \\
\text { ip bolus }\end{array}$ & $\begin{array}{l}9,9,9,10 \\
11\end{array}$ & $9.6 \pm 0.9$ & \\
\hline
\end{tabular}

"2 $2^{\prime} d c f$ was administered i.p. by continuous infuston or by bolus injections once daily. Treatment started one day before skin grafting and lasted until day 12 posttransplant.

- MST = mean graft survival lime \pm siandard deviation.

- Doses are indicated in $\mathrm{mg} / \mathrm{kg}$ body weight per day.

a $p<0.005$, by Wilcoxon rank test for comparing the survival of the experimental group and the control group (group 1 ).

phocytes were isolated for mitogen stimulation. Control animals were neither grafted nor treated. The results are given in Table 2. Lymphocytes from animals treated with 2 'def showed a marked decrease in Con A response. The mitogen response was depressed during 2 'dcf therapy, and inhibition lasted at least until day 15 , three days after withdrawal of treatment. Grafted animals that were untreated did not show changes in mitogen responsiveness as compared to control rats.

Toxicity of 2'dcf. Animals used for mitogen response experiments were also examined for 2'dcf toxicity. Rats that received 2'dcf showed a marked loss of body 
TABLE 2. Effect of $2^{\prime}$ def treatment and skin grafting on mitogen-induced blastogenesis of splenic $T$ lymphocytes

\begin{tabular}{|c|c|c|c|}
\hline & \multicolumn{2}{|c|}{$\begin{array}{l}{ }^{3} \mathrm{H} \text { thymidine incorporation } \\
\text { (cpm) }\end{array}$} & \multirow{2}{*}{$\begin{array}{l}\text { Stimulation } \\
\text { index } \pm \mathrm{SD} \\
\text { Con } \mathrm{A}\end{array}$} \\
\hline & Background & Con $A$ & \\
\hline Control: & 3523 & 73,872 & $21.0 \pm 3.5$ \\
\hline \multicolumn{4}{|c|}{ Untreated: } \\
\hline day 3 & 3266 & 62,737 & $19.2 \pm 0.4$ \\
\hline day 7 & 2165 & 43,178 & $19.9 \pm 4.2$ \\
\hline day 11 & 3529 & 71,016 & $20.1 \pm 0.9$ \\
\hline \multicolumn{4}{|c|}{$2^{\prime}$ dof treated: } \\
\hline day 3 & 494 & 1472 & $3.0 \pm 0.6^{b}$ \\
\hline day 7 & 406 & 1104 & $2.7 \pm 1.2^{b}$ \\
\hline day $\mathbb{1}$ & 840 & 6343 & $7.6 \pm 2.8^{6}$ \\
\hline day 15 & 526 & 2682 & $5.1 \pm 5.0$ \\
\hline day 19 & 1465 & 43,060 & $29.4 \pm 9.3$ \\
\hline
\end{tabular}

if Rats were grafted on day 0 and were untreated or treated with $2^{\prime} \mathrm{dcf} 0.5 \mathrm{mg} / \mathrm{kg}$ body wt/day given by continuous infusion from day - I till day 12. Control animals were neither grafied nor treated. Spleens were removed on the days indicated, and splenic lymphocytes were stimulated with Con $A$. During every experiment cells from control animals were also stimulated to exclude technical failures during the experiment. Data given are meams of determinations from 3, 4, or 5 rats. Days after skin grafting are given.

b $p \leqslant 0.05$, by Wilcoxon rank test for difference between treated and unireated animals on day indicated.

weight, as shown in Table 3 . This decrease in weight reflects a state of anorexia that was apparent during 2 'def treatment. Loss of body weight became worse during treatment and was $29 \%$ at day 11 . After withdrawal of treatment, body weight increased rapidly.

The striking consequence of 2 dcf treatment was the toxicity to the lymphoid tissues. Dramatic decreases in splenic weight and total splenic cell count were observed (Table 3). On day 11 mean splenic weight was decreased by almost 50\% as compared to control animals, and total splenic cell count decreased by more than $75 \%$. On day 19 , seven days after withdrawal of treatment, values were returning to normal. After transplantation rats that were not treated also showed a decrease in splenic weight and total splenic cell count; but these changes were less marked.

The lymphocytotoxic effect of $2^{\prime} \mathrm{dcf}$ was also demonstrated by the extreme lymphopenia in peripheral blood (Table 4). In rats that were skin-grafted and treated with $2^{2}$ dcf the percentage of lymphocytes decreased to $17 \%$ on day 11 , although the total leukocyte count showed a slight increase. In contrast, rats that were untreated after grafting showed normal differential lymphocyte counts of $83-86 \%$, with nearly 
TABLE 3. Effect of $2^{\prime}$ def treatment on body weight, splenic weight and total splenic cell count $^{3}$

\begin{tabular}{|c|c|c|c|c|c|}
\hline & $\begin{array}{l}\text { Body weight } \\
\text { day 0 (g) }\end{array}$ & $\begin{array}{l}\text { Body weight } \\
\text { (g) on day } \\
\text { indicated }\end{array}$ & $\begin{array}{l}\text { Change of } \\
\text { body weight } \\
0 \% \pm \mathrm{SD}\end{array}$ & $\begin{array}{l}\text { Splemic } \\
\text { weight } \\
\text { (mg) }\end{array}$ & $\begin{array}{l}\text { Total } \\
\text { amount of } \\
\text { splenic cells } \\
+\mathrm{SD} \times 10^{7}\end{array}$ \\
\hline Control: & 270 & - & - & 503 & $49.5 \pm 1.3$ \\
\hline $\begin{array}{l}\text { Untreated: } \\
\text { day } 3 \\
\text { day } 7 \\
\text { day } 11\end{array}$ & $\begin{array}{l}283 \\
293 \\
270\end{array}$ & $\begin{array}{l}265 \\
285 \\
261\end{array}$ & $\begin{array}{l}-6.4 \pm 1.9 \\
-2.7 \pm 1.0 \\
-3.3 \pm 2.0\end{array}$ & $\begin{array}{l}452 \\
456 \\
449\end{array}$ & $\begin{array}{l}37.0 \pm 1.6 \\
47.1 \pm 0.5 \\
40.5 \pm 2.3\end{array}$ \\
\hline $\begin{array}{l}\text { 2'dcf treated: } \\
\text { day } 3 \\
\text { day } 7 \\
\text { day } 11 \\
\text { day } 15 \\
\text { day } 19\end{array}$ & $\begin{array}{l}275 \\
287 \\
290 \\
288 \\
292\end{array}$ & $\begin{array}{l}247 \\
246 \\
206 \\
216 \\
256\end{array}$ & $\begin{array}{l}-10 \pm 1.0^{b} \\
-14 \pm 2.3^{b} \\
-29 \pm 1.4^{b} \\
-25 \pm 2.7 \\
-12 \pm 6.0\end{array}$ & $\begin{array}{l}456 \\
563 \\
263 \\
333 \\
400\end{array}$ & $\begin{array}{l}28.1 \pm 7.7 \\
34.2 \pm 5.2^{b} \\
10.0 \pm 4.8^{b} \\
11.6 \pm 4.6 \\
32.2 \pm 9.4\end{array}$ \\
\hline
\end{tabular}

a Rats were grafted on day 0 and killed on the day indicated. Animals were untreated or treated with $2^{\prime}$ dcf $0.5 \mathrm{mg} / \mathrm{kg}$ body wt/day given by continuous infusion from day - 1 till day 12. Conirol animals were neither grafted nor treated. Animal weight was obtained at day - I and prior to death. Splenic cell count was determined immediately after mincing the spleen. Data given are means of determinations from 3, 4, or 5 rats. Days after skin grafting are given.

b $p \leqslant 0.05$, by Wilcoxon rank test for difference berween treated and untreated animals on doy indicated.

TABLE 4. Effect of $2^{\prime}$ def treatment on rat peripheral blood

\begin{tabular}{|c|c|c|c|c|}
\hline & $\begin{array}{l}\text { Total leukocyte } \\
\text { count, cells } / \mathrm{m} \|\end{array}$ & $\begin{array}{l}\text { Percentage of } \\
\text { lymphocytes } \\
\pm \text { SD }\end{array}$ & $\begin{array}{l}\text { Percentage of } \\
\text { neutrophiles }\end{array}$ & $\begin{array}{l}\text { Hematocrit } \\
(\%)\end{array}$ \\
\hline Conirol: & $9.2 \times 10^{6}$ & $85 \pm 5$ & 12 & 51 \\
\hline $\begin{array}{l}\text { Unireated: } \\
\text { day } 3 \\
\text { day } 7 \\
\text { day } 11\end{array}$ & $\begin{array}{r}10.7 \times 10^{6} \\
11.4 \times 10^{6} \\
9.7 \times 10^{6}\end{array}$ & $\begin{array}{l}84 \pm 6 \\
83 \pm 4 \\
86 \pm 3\end{array}$ & $\begin{array}{r}12 \\
14 \\
9\end{array}$ & $\begin{array}{l}51 \\
52 \\
52\end{array}$ \\
\hline $\begin{array}{l}2 \text { 'dcf treated: } \\
\text { day' } 3 \\
\text { day } 7 \\
\text { day } 11 \\
\text { day } 15 \\
\text { day' } 19\end{array}$ & $\begin{array}{l}12.5 \times 10^{6} \\
26.3 \times 10^{6} \\
12.9 \times 10^{6} \\
13.5 \times 10^{6} \\
11.3 \times 10^{6}\end{array}$ & $\begin{array}{l}27 \pm 2 \\
18 \pm 3 \\
17 \pm 3 \\
18 \pm 2 \\
62 \pm 5\end{array}$ & $\begin{array}{l}70 \\
76 \\
78 \\
76 \\
35\end{array}$ & $\begin{array}{l}42 \\
46 \\
57 \\
50 \\
49\end{array}$ \\
\hline
\end{tabular}

"Rats were grafted on day 0 and blood was taken on the day indicated. Animals were untreated or treated with $2^{*} \mathrm{dcf} 0.5 \mathrm{mg} / \mathrm{kg}$ body wt/day given by contimuous infusion from day - I lill day 12. Control animals were neither grafted nor treated. Data given are means of determinations from 3, 4 or 5 rats. Days after skin grafting are given. 
normal total leukocyte counts. Lymphopenia in 2 'dcf treated animals did not result in a decrease of total leukocyte count, because the neutrophil population clearly increased. This indicates that neutrophils are resistent to the effect of 2 'dcf. Erythropoiesis was not markedly effected by $2^{\prime} \mathrm{dcf}$, as demonstrated by the hematocrit.

Immunofluorescence. In order to examine the influence of 2 'dcf on different lymphocyte subsets during skin graft rejection, immunofluorescence examinations were performed on splenic lymphocytes.

Animals untreated or treated with continuously infused 2 'dcf, $0.5 \mathrm{mg} / \mathrm{kg}$ body wt/day, were killed at various days after skin transplantation, and splenic lymphocytes were labeled with monoclonal antibodies. A control group was formed by rats that were neither grafted nor treated. The results of these experiments are given in Table 5.

Untreated rats showed a small increase in the percentage of $T$ cells on day 7 posttransplant. This increase was due to a rise in the percentage of W3/25+ cells (helper $\mathrm{T}$ cells), while the percentage of $\mathrm{OX} 8^{+}$cells (suppressor/cytotoxic $\mathrm{T}$ cells) remained nearly constant. This was illustrated by a slight increase of the W3/25: OX8 ratio, which rose to 3 on day 7 posttransplant. In rats that were treated with 2 'dcf, changes in lymphocyte subsets showed a different pattern. These animals also demonstrated a rise in the percentage of $T$ cells, but in contrast to untreated animals they showed an increased percentage of $\mathrm{OX}^{+}{ }^{+}$cells, whereas the percentage of $\mathrm{W} 3 / 25^{+}$cells remained almost constant during therapy. This resulted in a clear decrease of the W3/25: OX8 ratio (Fig. 1).

The total amount of lymphocytes in the spleen decreased tremendously during 2 ' $\mathrm{dcf}$ treatment (Table 3). From these data, and the figures obtained from immunofluorescence, it can be calculated that the total amount of lymphocytes in each subpopulation markedly decreased during 2'dcf therapy ( $T$ cells, helper T cells, suppressor/cytotoxic T cells, and $\mathrm{B}$ cells). However, $\mathrm{OX}_{8}{ }^{+}$cells were more resistant to the effect of 2 'dcf than $\mathrm{W} 3 / 25^{+}$cells. Mark $\mathrm{I}^{+}$cells (B cells) were also affected by the drug. The effect of $2^{\prime} \mathrm{dcf}$ therapy on lymphocyte subsets was long-lasting; it was still apparent after withdrawal of treatment.

\section{Discussion}

Our study demonstrates that 2 'def given by continuous infusion can lead to complete suppression of skin graft rejection during treatment. The 2'dcf given by continuous infusion at a dose of $0.7 \mathrm{mg} / \mathrm{kg}$ body wt $/$ day resulted in an MST of 20.3 days, and the interval between withdrawal of treatment and rejection closely equalled graft survival time in untreated controls. In the dosages tested, ip bolus in-

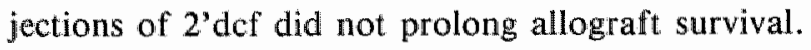

The strong immunosuppressive properties of continuously infused 2'dlcf were also 
TABLE 5. FACS analysis of lymphocyte subpopulations in the spleen ${ }^{\text {n }}$

\begin{tabular}{|c|c|c|c|c|c|}
\hline & $\begin{array}{l}\text { OX } 19^{\circ} \\
\text { cells } \\
(0 \%)\end{array}$ & $\begin{array}{l}\mathrm{OX} 8^{*} \\
\mathrm{cells} \\
(0 \%)\end{array}$ & $\begin{array}{l}\text { W3/25 } \\
\text { cells } \\
(\%)\end{array}$ & $\begin{array}{l}\text { Mark I+ } \\
\text { cells } \\
(\%)\end{array}$ & $\begin{array}{l}W 3 / 25: 0 \times 8 \\
\text { ratio } \pm \mathrm{SD}\end{array}$ \\
\hline Control: & 55 & 17 & 44 & 30 & $2.6 \pm 0.3$ \\
\hline $\begin{array}{l}\text { Untreated: } \\
\text { day } 3 \\
\text { day } 7 \\
\text { day } 11\end{array}$ & $\begin{array}{l}61 \\
68 \\
55\end{array}$ & $\begin{array}{l}15 \\
18 \\
18\end{array}$ & $\begin{array}{l}45 \\
54 \\
42\end{array}$ & $\begin{array}{l}25 \\
27 \\
29\end{array}$ & $\begin{array}{l}3.0 \pm 0.6 \\
3.0 \pm 0.3 \\
2.3 \pm 0.3\end{array}$ \\
\hline $\begin{array}{l}2 \text { 'dcf ireated: } \\
\text { day } 3 \\
\text { day } 7 \\
\text { day } 11 \\
\text { day } 15 \\
\text { day } 19\end{array}$ & $\begin{array}{l}62 \\
57 \\
73 \\
76 \\
68\end{array}$ & $\begin{array}{l}26 \\
29 \\
27 \\
30 \\
31\end{array}$ & $\begin{array}{l}42 \\
32 \\
48 \\
51 \\
44\end{array}$ & $\begin{array}{l}28 \\
30 \\
16 \\
15 \\
13\end{array}$ & $\begin{array}{l}1.6 \pm 0.4^{b} \\
1.1 \pm 0.4^{b} \\
1.8 \pm 0.4 \\
1.7 \pm 0.8 \\
1.4 \pm 0.1\end{array}$ \\
\hline
\end{tabular}

- Rats were grafted on day 0 and were untreated or treated with $2^{\prime}$ dcf $0.5 \mathrm{mg} / \mathrm{kg}$ body wi/day given by continuous infusion from day 1 till day 12. Control animals were neither. grafted nor treated. Spleens were removed on days indicated and splenic lymphocytes were labeled as described in materials and methods. Results are shown as means of determinations from 3, 4, or 5 rats. Days after skin grafting are given.

b $p \leqslant 0.05$, by Wilcoxon rank test for difference between treated and untreated animals on day indicated.

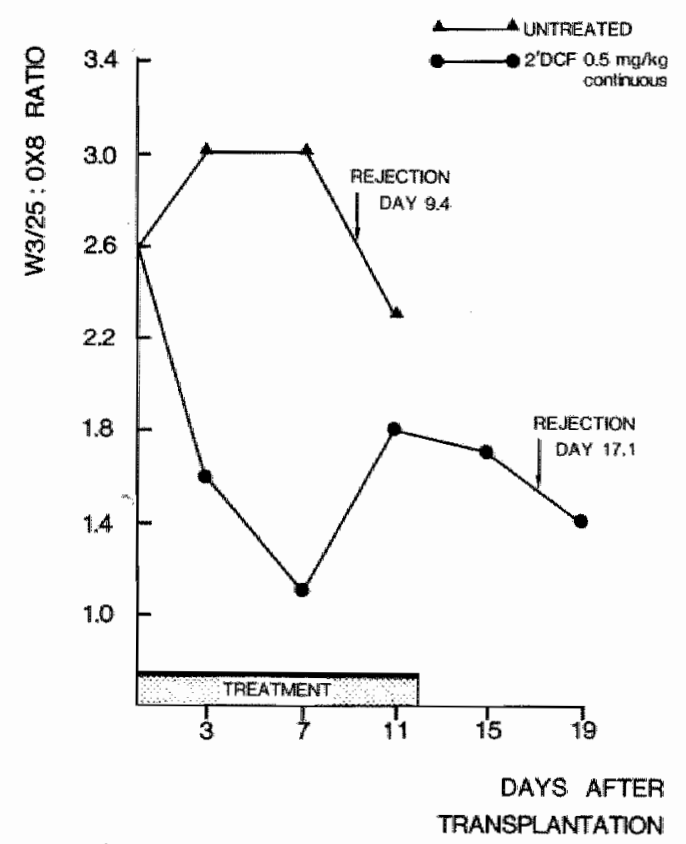

FIGURE 1. W3/25: OX8 ratio after skim grafting in untreated rats and rats treated with 2 'dcf $0.5 \mathrm{mg} / \mathrm{kg}$ body wt/day administered by continuous infusion. 
demonstrated by suppression of mitogen-induced blastogenesis. Lymphocytes of $2^{\prime}$ dcf-treated rats showed a clearly suppressed mitogen response to Con A in vitro. That 2'dcf had an extremely lymphocytotoxic effect was indicated by marked decreases in splenic cell count and peripheral lymphocyte count. This toxic effect of $2^{\prime}$ def was specific for lymphocytes, whereas neutrophils proved to be resistent to the drug.

We demonstrated that both $T$ cells and B cells were sensitive to 2 'dcf treatment. A clear decrease in Mark $\mathrm{I}^{+}$cells (B cells) was observed, which is consistent with reports of others who demonstrated that lymphocytes from mice treated with 2'dcf showed disturbed mitogen responsiveness to lipopolysaccharides (12). Although the percentage of $T$ cells increased, as shown by immunofluorescence, it is evident from the total lymphocyte count that the total amount of $T$ cells decreased. Both $T$ cell subsets were affected by the drug, $\mathrm{W} 3 / 25^{+}$cells (helper $\mathrm{T}$ cells) as well as $\mathrm{OX} 8^{+}$ cells (suppressor/cytotoxic $\mathrm{T}$ cells). Recent reports suggest that low concentrations of 2 'dcf or deoxyadenosine preferentially affect $T$ suppression function, whereas higher concentrations are needed to affect $T$ helper function $(27,28)$. In our model using a high dose of $2^{\prime} \mathrm{dcf}\left(0.5 \mathrm{mg} / \mathrm{kg}\right.$ body wt/day), $\mathrm{OX} 8^{+}$cells were shown to be more resistent to the drug compared with $\mathrm{W} 3 / 25^{+}$cells. The absolute number of both $\mathrm{OX8} 8^{+}$cells and $\mathrm{W} 3 / 25^{+}$cells in the spleen decreased, but the percentage of $\mathrm{OX} 8^{+}$cells rose, whereas the percentage of $\mathrm{W} 3 / 25^{+}$cells remained almost constant during therapy.

Concerning the immunosuppressive effect of $2^{\prime} \mathrm{dcf}$, it may be important that especially $\mathrm{W} 3 / 25+$ cells are susceptible to the toxic effect of $2^{*}$ def. In skin allograft rejection, W3/25+ cells are generally considered to be of major importance in the rejection process $(29,30)$. Whether reduction of $\mathrm{W} 3 / 25^{+}$cells is part of the immunosuppressive effect of 2 'dcf remains to be established.

Several studies have been performed to demonstrate the lymphocytotoxic and immunosuppressive effect of 2 'dcf. According to the mode of drug administration, variable results have been reported. Single injections of 2 'dcf given one or more times daily appeared to result in a marginal immunosuppressive effect. In mice treated once daily skin grafts across the H2-barrier were rejected 3 days later, as compared to skin grafts in untreated animals (12). In dogs single injections of $2^{\prime} \mathrm{dcf}$ resulted in prolongation of skin graft survival, nevertheless, grafts were rejected during therapy (25). Better results were reported if 2 'dcf was administered by continuous infusion. Tedde (12) showed that continuous infusion of 2 'dcf suppressed the DTH reaction in mice. The lymphocytes of these mice showed a markedly suppressed mitogen response in vitro. Sordillo et al. (24) demonstrated that 2 'dcf administered by continuous infusion compared with single injections resulted in greater lymphocytotoxicity. The results of these studies are consistent with our finding that 2 'dcf is a potent immunosuppressive drug if given by continuous infusion. Although less is known about the pharmacodynamics of 2'dcf in the rat, pharmacological data obtained in other animals may explain these results. In dogs and mice, plasma $T^{1 / 2}$ of 2 'dcf is short, and in mice the half-life time was found to be 64-104 
minutes $(31,32)$. The drug is rapidly cleared in urine, and the clearance in the dog is equal to the inulin clearance. In addition it is also relevant that recovery of ADA activity after a 2 'def bolus injection is time-dependent and tissue-dependent. In rats it was observed that ADA activity of spleen and red blood cells is almost completely abolished after $2^{\prime} \mathrm{dcf}$ injection ( $0.25 \mathrm{mg} / \mathrm{kg}$ body weight). However ADA activity of the spleen recovered to $50 \%$ within 24 hours, whereas red blood cells showed minimal recovery at this time (32). Therefore it is expected that continuous infusion provides a constant low level of 2 'dcf in the circulation and hence a more efficient and continuous inhibition of ADA activity resulting in a better immunosuppressive effect.

The immunosuppressive effect of 2 'dcf has been extensively studied in vitro. Although there is variability in these data the studies indicate that 2 'dcf alone is not very effective in suppression of mitogen-induced proliferation $(19,21)$. High concentrations of adenosine or deoxyadenosine are, however, often antiproliferative $(14,16,17)$. The combination of adenosine or deoxyadenosine and 2 'def has been shown to act synergistically, and mitogen-induced proliferation or MLC response are clearly inhibited by this combination $(19,20)$. We demonstrated that 2 'def administered in vivo by continuous infusion markedly depressed mitogen induced blastogenesis. This finding is in concordance with Sordillo (24) who also showed that 2 'dcf given as sole agent to mice inhibited mitogen induced blastogenesis in vitro. The abovementioned data suggest that in vivo the interaction between lymphoid tissues and circulating levels of adenosine and deoxyadenosine is of importance in the genesis of the immune-deficient state acquired.

The selective trapping of deoxyadenosine by lymphoid tissues has been postulated to represent a mechanism that brings about this interaction. Carson (6) showed that deoxyadenosine kinase activity in man is largely localized in lymphoid cells, enabling only these cells (and presumably erythrocytes as well) to phosphorylate the freely diffusible deoxyadenosine and trap it within the cell as the nondiffusible deoxynucleotide derivative resulting in accumulation of d'ATP and lymphocytotoxicity. Whether this mechanism is also relevant in the rat remains to be established. In our experiments 2'def therapy started before skin grafting, and it is likely that $2^{\prime} \mathrm{dcf}$ interfered early in the immune response. It is, however, unknown, if $2^{\prime} \mathrm{dcf}$ is also effective in abrogating the immune response when given some days after skin transplantation. In vitro data suggest that activated $T$ lymphocytes are resistent to 2 'dcf, and it is suggested that the process of T cell activation brings about a change in adenosine and deoxyadenosine metabolism that renders these cells resistent to the accumulation of toxic metabolites of these nucleotides (33). Whether this resistence is present in the in vivo situation must be tested.

In clinical trials 2 'def was used as an antitumor agent in patients with lymphoproliferative malignancies (34). In these studies $2^{\prime} \mathrm{dcf}$ was given allone or in com-

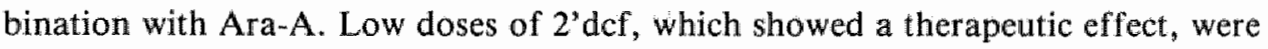
safe and tolerable. At high doses neurotoxicity and nephrotoxicity were observed, although nephrotoxicity was mostly seen in patients with prior renal impairment. 
In our rats, which received 2 'dcf by continuous infusion at a dose of $0.5 \mathrm{mg} / \mathrm{kg}$ body wt/day, blood urea levels were determined (data not shown) and no signs of nephrotoxicity could be demonstrated. However, the toxic effects of $2^{y} \mathrm{dcf}$ in leukemic patients may differ from those in healthy humans, because tumor degradation products may play a role in the toxic effects.

Acknowledgments. This work was supported by the Dr. Saal van Zwanenbergstichting and Fungo (grant no. 29.57.10). 2'deoxycoformycin was kindly provided by the National Cancer Institute, U.S.A. We thank Mrs. E.E.M. Spronken for technical assistance and Mrs. K. Spronck for secretarial assistance.

Abbreviations used in this article. ADA, adenosine deaminase; BSA, bovine serum albumin; Con A, concanavalin A; 2'dcf, 2'deoxycoformycin; DTH, delayed type hypersensitivity; FACS, fluorescence-activated cell sorter; FCS, fetal calf serum; FITC, fluorescein isothiocyanate; MLC, mixed leukocyte culture; MST, mean graft survival time; PBS, phosphate buffered saline.

\section{References}

1. Giblett $E R$, Anderson $\mathrm{JE}_{\text {, }}$ Cohen $\mathrm{F}$, Pollara $\mathbb{B}$, Meuwissen HJ. Adenosine deaminase deficiency in two patients with severely impaired cellular immunity. Lancet 1972; 2 : 1067.

2. Dissing J, Krudsen B. Adenosine deaminase deficiency and combined immunodeficiency syndrome. Lancet 1972; 2: 1316 .

3. Meuw issen HJ, Pollara B, Pickering RJ. Combined immunodeficiency disease associated with adenosine deaminase deficiency. J Pediatr 1975; 86: 169.

4. Thompson LF, Seegmiller JE. Adenosine deaminase deficiency and severe combined immunodeficiency disease. Adv Enzymol 1980; $51: 167$.

5. Mitchell BS, Kelley WN. Purinogenic Immunodeficiency disease: clinical features and molecular mechatisns. Ann Intern Med 1980; 92: 826 .

6. Carson DA, Kay J, Seegmiller JE. Lymphospecific toxicity in adenosine deaminase deficiency and purine nucleoside phosphorylatse deficiency: Possible role of nucleoside kinase(s). Proc Natl Acad SCI USA 1977; $74: 5677$.

7. Wormann RL, Mitchell BS, Edwards NL, Fox JH. Biochemical basis for clifferential deoxyadenosine toxicity to Th and B lymphoblasts: Role of 5 -nucleotidase. Proc Natl Acad Sci USA 1979; 76: 2434.

8. Redelman D, Blluestein HG, Cohen AH, Depper IM, Wormsley S. Deoxyadenosine (AdR) inhibithon of newly activated lymphocytes: Blockade at $\mathrm{G}_{0}-\mathrm{G}_{1}$ interface. J Imnunol $1984,132: 2030$.

9. Uberti $J_{v}$ Lighthody $J J_{\text {, Johnson }} \mathrm{RM}$. The effect of nucleosides and deoxycoformycin on ad enosine and deoxyadenosine inhibition of human lymphocyte activation. I Immunol 1979; 123: 189 .

10. Agarwal RP, Spector T, Parks RE. Tight-binding inhibition of adenosine deaminase by various ünhibitors. Biochem Pharmacol 1977; 26: 359.

11. Smyth JF, Young RC, Young DM. In vivo toxicity to lymphoid tissue by $2^{\prime}$ deoxycoformycin. Can Chem Pharmacol 1978; 1:49.

12. Tedde A, Balis ME, Ikehara S, Pahwa R, Good RA, Trotta PP. Animal model for immune dysfunction associated with adenosine deaminase deficiency. Proc Narl Acad Sci USA 1980; 77: 4899.

13. Trota PP, Tedde A, Ikehara S, Pahwa R, Good RA, Balis ME. Specific immunosuppressive effects of constant infusion of $2^{\prime}$ deorycoformycin. Cancer Res 1981; 41:2189. 
14. Simmonds HA, Panay GS, Corrigall V. A role of purine metabolism in the immune response: adenosine deaminase activity and deoxyadenosine catabolism. Lancet 1978 $1: 60$.

15. Mitchell BS, Mejias E, Daddona PE, Kelley WN. Purinogenic immunodeficiency diseases: selectiwe toxicity of deoxyribonucleosides for T calls. Proc Natl Acad Sci 1978; 75: 5011 .

16. Carson DA, Kaye J, Seegmiller JE. Differential sensitivity of human leukemie $T$ cell lines and $B$ cell lines to growth inhibition by deoxyadenosine. $J$ Immunol $1978 ; 121: 1726$.

17. Gelfand $\mathrm{EW}$, Lee $\mathrm{JJ}_{\text {, }}$ Dosch HM. Selective toxicity of purine deoxynucleosides for human lymphocyte growth and function. Proc Natl Acad Sci USA $1979 ; 76: 1998$.

18. Ratech H, Kuritsky L, Thorbecke GJ, Hirschhorn R. Suppression of human Iymphocyte DNA and protein synthesis in vitro by adenosine and eight modified adenine nucleosides in the presence or in the absence of adenosine deaminase inhibitors, 2'deoxycoformycin (DCF) and erythro-9-(2-Hydroxy-3 nonyl) Adenine (EHNA). Cell Immunoll 1982; 68: 244.

19. Brox LW, Pollock E, Belch A. Adenosine and deoxyadenosine toxicity in colony assay systems for human T-lymphocytes, B lymphocytes, and gramulocytes. Can Chem Pharmacol 1982; $9: 49$.

20. Hovi T, Smyth JF, Allison AC, Williams SC. Role of adenosine deaminase in lymphocyte proliferation. Clin exp Immunol 1976; 23: 395.

21. Burridge PW, Paetkau V, Henderson JF, Studies of the relationship between adenosine deaminase and immune function. J Immunol 1977; 119:675.

22. Earle MF, Glazer RI. 2'Deoxycoformycin toxicity in murin spleen lymphocytes. Mol Pharmacol 1983; 23: 165.

23. Chassin MM, Chirigos M, Johns DG, Adamson RH. Adenosine deaminase inhibition for immunosuppression. N Engl J Med 1977; 296: 1232.

24. Sordillo EM, Ikehara S, Good RA, Trotta PP. Immunosuppression by 2'deoxycoformycin: studies on the mode of administration. Cell Irmmunol 1981; 63: 259.

25. Epstein $\mathrm{RB}$, Fey $T$, Sarpel $S$. Prolongation of canine skin graft survival by deoxycoformycin. Transplantation 1982; 33: 208.

26. Bazin $\mathrm{H}$, Xhurdebise LM, Burtonboy $\mathrm{G}$, Lebacq AM, De Clercq L, Cormont F, Rat monoclonal antibodies 1 . Rapid purification from in vitro culture supernatants. J Immunol Methods 1984; 66: 261 .

27. Cohen $\mathrm{AH}$, Bluestein $\mathrm{HG}$, Redelman D. Deoxyadenosine modulates human suppressor T cell function and $\mathbb{B}$ cell differentiation stimulated by staphylococcus aureus protein $\mathbf{A}$. J Immunol 1984; 132: 1761.

28. Ratech $\mathbf{H}$, Bell MK, Hirschhorn $\mathrm{R}$, Thorbecke $\mathrm{GJ}$. Effects of deoxycoformyein in mice. I Suppression and erhancement of in vivo antibody responses to thymusdependent and -independent antigens. I Immunol 1984; 132: 3071.

29. Loveland BE, Hogarth PM, Geredig RH, McKenzie IFC. Cells mediating graft rejection in the mouse. I. Lyt-1 cells mediate skin graft rejection. J Exp Med 198:; 153: 1044.

30. Dallman MJ, Mason DW, Webb M. The roles of host and donor cells in the rejection of skin allografts by $T$ cell-deprived rats injected with syngeneic $T$ cells. Eur $J$ Immunol 1982; 12: 511 .

31. McConnel WR, Suling WJ Rice LS, Shannon WM, Hill DL. Use of microbiologic and enzymatic assays in studies on disposition of $2^{z}$ deoxycoformycin in the mouse. Cancer Treat Rep 1978; 62: 1453.

32. Chassin MM, Adamson RH, Zaharevitz DW, Johns DG. Enzym inhibition titration assay for 2:deoxycoformycin and its application on the study of the relationship between drug concentration and tissue adenosine deaminase in dogs and rats. Biochem Pharmacol 1979; 28: 1849.

33. Kotb $M$, Veit $B C$. Activated $T$ lymphocytes resist the toxic effect of adenosine deaminase inhibitor 2 'deoxycoformycin. Cell Immunol 1982; 72 : 64.

34. Annual report to the food and drug administration on deoxycoformycin and ARA-A. National Cancer Institute, October 1983. 


\section{Study 2}

Potency of $2^{\prime}$ deoxycoformycin and cyclosporin A on rat skin allograft survival.

Published in Transplantation Proceedings 1985; 17: 1333, entitled ' 2 'Deoxycoformycin; A new immunosuppressive drug with a potency comparable to cyclosporine". 


\section{Introduction}

Specific impairment of lymphocyte function is seen in adenosine deaminase (ADA) deficient-children $(1,2)$. Complete lack of ADA results in accumulation of adenosine and deoxyadenosine with severe dysfunction of cellular immunity and variable defect in humoral immunity. Inherited deficiency of the enzyme preferentially interferes with lymphocyte function while sparing most other organs (3).

$2^{\prime}$ Deoxycoformycin (2'dcf) is an effective inhibitor of ADA (4). The drug creates a metabolic state that mimics ADA deficiency. Such a manipulation of the purine metabolism that predominantly appears to effect lymphocytes seems an attractive approach for immunosuppression. Although theoretically attractive, the possible immunosuppressive effects of 2'dcf have hardly been studied in vivo. In this study, we tested 2 'def in a rat skin transplantation model, and the effect on graft survival was compared with results obtained with cyclosporin A (CyA).

\section{Materials and methods}

Animals. Inbred male $\mathrm{BN}\left(\mathrm{RT}^{\mathrm{n}}\right)$ and Lewis rats $\left(\mathrm{RT}^{\mathrm{L}}\right)$ of 250 to $300 \mathrm{~g}$ were used. Rats were supplied with acidified water and rat chow ad libitum.

Skin grafting. Full-thickness skin from the back of BN donor rats was grafted to the back of Lewis rats by the fitted graft technique. The graft was covered by a plaster bandage for 8 days. Afterwards, grafts were inspected daily and were considered to be rejected when complete necrosis of surface epithelium was observed.

Drug administration. Because the $T^{1 / 2}$ of $2^{\prime} \mathrm{dcf}$ is short, two methods of drug administration were tested. The drug was given either by intraperitoneal injections once daily or by constant infusion. CyA was always given by constant infusion. Drug administration was started one day before skin grafting (day-1) and lasted until day 12 .

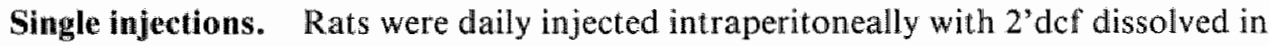
saline. Solutions were prepared at day -1 , filter sterilized, and kept at $37^{\circ} \mathrm{C}$. The amount of 2 'dcf administered was adjusted to body weight of the recipient at day -1 and remained constant during the experiment.

Constant infusion. Either $2^{\prime} \mathrm{dcf}$ or CyA was administered intraperitoneally by an osmotic minipump (2ML2, Alzet, Palo Alto, Calif) implanted in the abdominal cavity on day -1 . In this way, drugs were infused at a constant rate from day -1 to day 12. The dose of $2^{\prime} \mathrm{dcf}$ or CyA was adjusted to body weight of the recipient at day -1 . The $2^{\prime}$ def was dissolved in saline, the CyA, in ethanol. 
(in days)

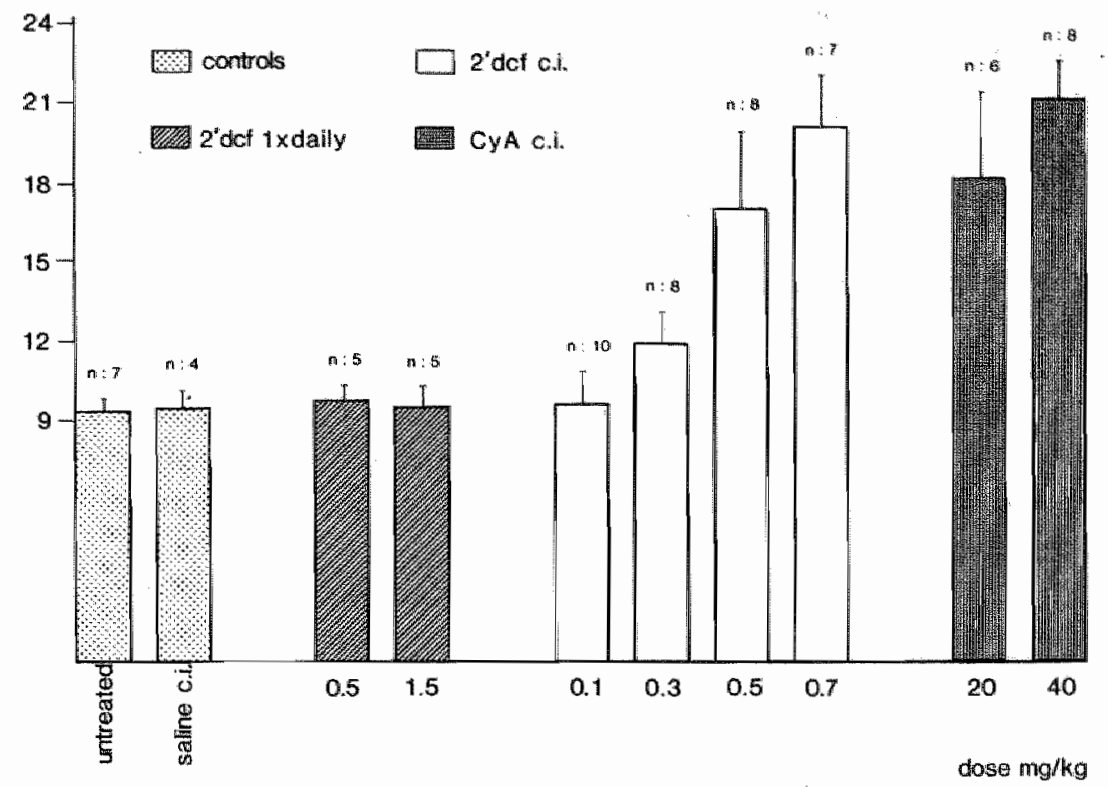

FIGURE 1. MST in rats treated with 2'dcf or CyA. Bars indicate standard deviation. Control rats were untreated or received constant infusion (c.i.) with saline.

\section{Results}

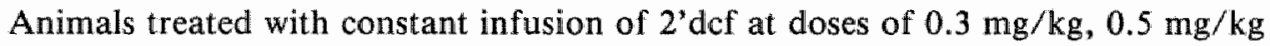
and $0.7 \mathrm{mg} / \mathrm{kg}$ body weight $/$ day showed significant prolongation of graft survival (Figure 1). The effect of the osmotic minipump on graft survival was negligible, since mean graft survival time (MST) in rats treated by constant infusion of saline was equal to MST in untreated controls. Rats treated daily with intraperitoneal injections of $2^{\prime} \mathrm{dcf}$ at doses of $0.5 \mathrm{mg} / \mathrm{kg}$ or $1.5 \mathrm{mg} / \mathrm{kg}$ body weight did not show prolongation of allograft survival, and grafts were rejected during treatment. Higher doses of 2 'dcf given by intraperitoneal bolus injection could not be tested because of shortage of the drug.

In rats treated by constant infusion of $2^{\prime} \mathrm{dcf}$ at a dose of $0.7 \mathrm{mg} / \mathrm{kg}$ body weight/day, the time interval between withdrawal of treatment and rejection was 8.3 days, a period almost identical to graft survival in control animals. This finding indicates that 2 'dcf at a dose of $0.7 \mathrm{mg} / \mathrm{kg}$ body weight/day given by constant infusion results in complete suppression of rejection.

In rats treated with CyA, a dose of $40 \mathrm{mg} / \mathrm{kg}$ body weight/day showed to be fully immunosuppressive, whereas a dose of $20 \mathrm{mg} / \mathrm{kg}$ body weight/day was not com- 
pletely effective. Rats treated with CyA, $40 \mathrm{mg} / \mathrm{kg}$ body weight/day, showed a MST that was comparable to that observed in rats treated with 2 ' $\mathrm{dcf} 0.7 \mathrm{mg} / \mathrm{kg}$ body weight/day.

\section{Discussion}

2 'def given by constant infusion is a strong immunosuppressive drug in rats. At a dose of $0.7 \mathrm{mg} / \mathrm{kg}$ body weight/day , constant infusion of $2^{\text {x }} \mathrm{dcf}$ completely suppresses skin graft rejection. In the doses tested, intraperitoneal bolus injection of $2^{\prime}$ def showed no immunosuppressive effect. The T $1 / 2$ of $2^{\prime} \mathrm{dcf}$ in rodents is short (5), and therefore, it may be reasonable that constant infusion provides a constant low level of $2^{y} \mathrm{dcf}$ and hence a better immunosuppressive activity as intraperitoneal bolus injection.

In its effect on skin graft survival, 2 'dcf resembles CyA. Both agents show complete suppression of allograft rejection during treatment; withdrawal of treatment leads to prompt rejection of skin allografts. The mechanism by which both agents act, however, is supposed to be different. CyA inhibits the production of lymphokines (6), and it was recently suggested that the drug interferes with the expression of MHC class II antigens (7). During $2^{\prime} \mathrm{dcf}$ treatment, inhibition of ADA leads to impaired DNA synthesis, although the exact biochemical mechanism by which this happens is unknown (8).

In clinical trials, 2 'dcf was used as antitumor agent in leukemic patients $(9,10)$. In these studies, low doses of 2 'dcf were tolerable. At high doses, neurotoxicity and nephrotoxicity were described. Nephrotoxicity in these patients was difficult to interpret because it occurred almost exclusively in patients with prior renal impairment. The toxic effects of 2 'def in leukemic patients may be completely different from those in healthy humans, because tumor degradation products may play a role in 2'dcf toxicity. In an organ transplantation model, 2'dcf has never been tested. Our study suggests that $2^{\prime}$ dcf may be a useful immunosuppressive agent, but further studies in this direction are necessary.

Acknowledgments. This work was supported by the Dr. Saal van Zwanenbergstichting. 2'Deoxycoformycin was given by Warner-Lambert Co., Ann Arbor, Mich. 


\section{References}

1. Gimblett ER, Anderson JE, Cohen F et al: Lancet 2: 1067, 1972

2. Thompson LF, Seegmillar JE: Adv enzymol 51: 167, 1980

3. Meuwissen HJ, Pollara B, Pickering RJ: J Pediatr 86: 169, 1975

4. Agarwal RP, Spector $T$, Parks RE: Biochem Pharmacol 26: 359, 1977

5. Glazer RI: Can Chem Pharmacol 4: 227, 1980

6. Reem GH, Cook LA, Vilcek J: Science 221: 63, 1983

7. Groenewegen G, Buurman WA, Jeunhomme GMAA: Transpl Proc: 17: 1417, 1985

8. Mitchell BS, Kelley WN: Ann Intern Med 92: 826, 1980

9. Grever MR, Siaw MF, Jacob WF et al: Blood 57: 406, 1981

10. Poplack DG, Sallan SE, Rivera $G$ et al: Cancer Res $41: 3343,1981$ 



\section{Study 3}

\section{The effect of 2'deoxycoformycin and deoxyadenosine on human $\mathrm{T}$ cell function.}

Published in The Journal of Immunology 1987; 138: 116, entitled ' 2 'deoxycoformycin and deoxyadenosine affect IL2 production and IL2 receptor expression of human T cells"'.

\section{Summary}

Congenital deficiency of the enzyme adenosine deaminase (ADA) leads to severe combined immunodeficiency. 2"Deoxycoformycin (dCF), a tightly binding inhibitor of ADA, can induce the metabolic state of ADA deficiency. In vivo, the drug causes specific impairment of lymphocyte function and shows strong immunosuppressive properties. However, to decide whether inhibition of the enzyme ADA offers an attractive approach for inmunosuppressive therapy more information is needed about the immunologic mechanisms affected.

In human $\mathrm{T}$ cells, we investigated the effect of $\mathrm{dCF}$ and deoxyadenosine (AdR) on cell activation, interleukin 2 (IL2) production and IL2 receptor induction after allogeneic and lectin-induced stimulation. After allogeneic stimulation, $\mathrm{dCF}$ and $\mathrm{AdR}$ affected several events in $T$ cellular immune response. Early events in $T$ cell activation showed to be most sensitive to the drugs. Primary MLC was completely inhibited by concentrations as low as $1 \mu \mathrm{M} \mathrm{dCF}$ and $1 \mu \mathrm{M}$ AdR. The addition of human recombinant IL2 (rIL2) could not abrogate the inhibitory effect of the drugs. Apart from activation of $T$ cells, the drugs interfered with proliferation of activated $T$ cells. Two events in activated $T$ cells were affected: IL 2 production and IL 2 receptor expression. In secondary MLC, IL2 production was markedly reduced in the presence of $9 \mu \mathrm{M} \mathrm{dCF}$ and $60 \mu \mathrm{M}$ AdR. These concentrations appeared also to affect IL2 receptor expression in 12 day primary MLC cells stimulated with II.L2. Lectin stimulation was also affected by the drugs. In phytohemagglutinin (PHA) stimulated cultures, $9 \mu \mathrm{M} \mathrm{dCF}$ and $60 \mu \mathrm{M}$ AdR resulted in inhibition of proliferation and IL2 receptor expression, whereas IL2 production was normal.

It is concluded that $\mathrm{dCF}$ and AdR interfere with several events in T cellular immune response such as cell activation, IL2 production, and IL2 receptor expression. According to these results, inhibition of the enzyme ADA seems an attractive approach to immunosuppressive therapy. 


\section{Introduction}

Adenosine deaminase (ADA) is assumed to play a central role in normal development of the immune system (1-4). In children, congenital deficiency of the enzyme ADA is associated with severe combined immunodeficiency disease. The disease is almost restricted to the lymphoid tissues, with relatively minor impairment of other organs. Children with ADA deficiency show thymus bypoplasia, profound impairment of $T$ lymphocyte function, and a variable loss of $B$ cell function $(3,4)$. Deficiency of the enzyme ADA, however, does not exclusively interfere with the development of the immune system. When in adult rodents ADA deficiency is induced by the drug 2'deoxycoformycin (dCF), a tightly binding inhibitor of ADA, lymphocyte function is severely impaired $(5,6)$. In these animals, inhibition of the enzyme ADA proves to be an effective way to induce immunosuppression $(7,8)$. Skin allograft rejection in rats is completely suppressed by dCF, and the drug shows an immunosuppressive potency comparable to Cyclosporin A (9).

It is proposed that inhibition of the enzyme leads to accumulation of deoxyadenosine (AdR) and deoxyadenosine triphosphate (dATP) within $T$ lymphocytes, and that either one or both of these metabolites would interfere with normal lymphocyte function (10-15). Selective trapping of AdR by lymphoid tissues has been postulated to be a mechanism that brings about selective toxicity for these tissues. Carson et al. (10) showed that AdR kinase activity in man is largely localized in lymphoid cells, mainly enabling these cells to phosphorylate the freely diffusible AdR and trap it within the cell as the nondiffusible deoxynucleotide derivative, resulting in specific lymphocytotoxicity. This phenomenon would also explain why in vitro dCF alone is not very effective in the suppression of mitogen-induced proliferation. In vitro adenosine or AdR must be added to dCF (16-19) to induce inhibition of mitogeninduced proliferation or mixed lymphocyte culture (MLC).

At present, immunologic mechanisms affected by these metabolic changes are not well understood. It has been suggested that ADA deficiency interferes with the cell activation process $(15,20)$ or lymphokine production $(21)$. Studies with dCF and AdR in vitro showed that inhibition of mitogen-induced proliferation was most effective when dCF and AdR were present from the initiation of culture $(15,20)$. Inhibition of DNA synthesis caused by accumulation of dATP was initially considered responsible for this effect $(10,22)$. Recently, however, it was reported that in newly activated lymphocytes, dCF and AdR exerted effect before the initiation of DNA synthesis and without accumulation of $\operatorname{dATP}(14,15)$. In human cells activated by phytohemagglutinin (PHA), dCF and AdR blocked the increase in RNA synthesis necessary to enter from the resting state (G0) into the G1 phase of the cell cycle (15). It was suggested that AdR by itself interfered with the cell activation process. Although in PHA response dCF and AdR blocked RNA synthesis early in the activation phase, they did not block all early events because interleukin 2 (IL2) production and IL2 receptor induction were shown to be completely normal in these cells (15). These findings were in contrast to observations made during mitogen-induced 
proliferation in rat cells (21). In rat thymocytes and lymphocytes stimulated with concanavalin A (Con A), IL2 production was reported to be markedly decreased in the presence of $\mathrm{dCF}$. Activated cells and cycling $\mathrm{T}$ cells are more resistant to the drugs, and high drug concentrations are needed to inhibit cell proliferation $(15,19,20)$. It is still assumed that in these cells, dCF and AdR inhibit DNA synthesis by accumulation of dATP; elevated levels of dATP inhibit the enzyme ribonucleotide reductase which leads to inhibition of DNA synthesis due to depletion of deoxynucleotide triphosphates (22-24).

So far, most investigations have been made with lymphoblastoid cell lines and PHA stimulations. More knowledge on the biologic consequences of $\mathrm{ADA}$ deficiency is necessary to decide the usefulness of ADA inhibitors as immunosuppressive drugs. Moreover, this information is needed to evaluate whether ADA-deficient children may be treated by biologic products such as lymphokines, instead of supplying them with ADA by means of blood transfusions when a histocompatible bone marrow donor is not available (25).

In human $\mathrm{T}$ cells, we investigated the effect of $\mathrm{dCF}$ and $\mathrm{AdR}$ on $\mathrm{T}$ cell activation, IL2 production, and IL2 receptor induction after allogeneic and lectin-induced stimulation. It was found that $\mathrm{dCF}$ and $\mathrm{AdR}$ affect several steps in primary MLC (prim. MLC) and secondary MLC (sec. MLC). We show inhibition of T cell activation defined as the unified process which leads to early events such as IL2 receptor expression, transferrin receptor expression, insulin receptor expression, and a large series of later events such as proliferation or cytotoxicity. Furthermore, it is shown that IL2 production and IL2 receptor induction are both inhibited by $\mathrm{dCF}$ and AdR in a dose-dependent way. The results presented here demonstrate that inhibition of the enzyme ADA offers an attractive approach to immunosuppressive therapy.

\section{Materials and methods}

Cell preparation and culture conditions. Heparinized blood was obtained from normall healthy donors: mononuclear cells were prepared by density centrifugation of blood on Lymphoprep (Nyegaard, Oslo, Norway). All cultures were performed in RPMI 1640 (GIBCO Europe, Paisley, Scotland) containing 10\% human serum, $100 \mathrm{IU} / \mathrm{ml}$ penicillin, and $100 \mu \mathrm{g} / \mathrm{ml}$ streptomycin. Cultures were kept in humidified atmosphere of $5 \% \mathrm{CO}_{2}$ in air at $37^{\circ} \mathrm{C}$. 2'Deoxycoformycin was provided by the National Cancer Institute (Bethesda, MD, U.S.A.). Deoxyadenosine was purchased from Sigma Chemical Co. (St. Louis, MO). In the assays described below, human recombinant IL2 (rIL2) was diluted with complete medium to a final concentration of $2.5 \times 10^{-2} \mu \mathrm{g} / \mathrm{ml}$ (rIL2, Janssen Chimica, Beerse, Belgium).

Primary mixed lymphocyte culture. Unidirectional mixed lymphocyte cultures were performed in microtiter plates by culturing $10^{6}$ cells $/ \mathrm{ml}$ responder lymphocytes with $5 \times 10^{5}$ cells $/ \mathrm{ml}, 4000 \mathrm{rad} \mathrm{X}$-irradiated stimulator lymphocytes. Cells 
were incubated for 7 days and were pulsed with ${ }^{3} \mathrm{H}-\mathrm{TdR}$ for the last $4 \mathrm{hr}$ of culture. Cells were collected with a microharvester and ${ }^{3} \mathrm{H}-\mathrm{TdR}$ uptake was assayed by liquid scintillation. All tests were done in triplicate.

Secondary mixed lymphocyte culture. Alloantigen primed lymphocytes $\left(2.5 \times 10^{5}\right.$ cells $/ \mathrm{ml}$ ) obtained at day 12 of culture were restimulated with 4000 rad-X irradiated original stimulator cells at a density of $10^{6} \mathrm{ce} / \mathrm{l} / \mathrm{ml}$. All tests were done in triplicate and cultures were kept under standard conditions for 3 days. On day $3,{ }^{3} \mathrm{H}-$ TdR uptake was measured.

Mitogen stimulation. Lymphoid cells were cultured in microtiter plates at a density of $10^{6} \mathrm{cells} / \mathrm{ml}$. PHA 15 (Wellcome, Beckenham, UK) was added in an optimal concentration of $1 \%$ and cultures were kept under standard conditions. On day 3, ${ }^{3} \mathrm{H}-\mathrm{TdR}$ uptake was determined. All tests were done in triplicate.

Production of IL2 containing supernatant. Conditioned medium with IL2 activity was prepared by incubating peripheral blood lymphocytes $\left(10^{6}\right.$ cells $\left./ \mathrm{ml}\right)$ with PHA. Cells were cultured in cluster wells in a volume of $2 \mathrm{ml}$ and were incubated under standard conditions for $24 \mathrm{hr}$. At that time, supernatants were harvested, were centrifuged to remove cells, and were filtered through a $0.22 \mu \mathrm{M}$ sterile MillexGV filter unit (Millipore, Molsheim, France). Also, sec. MLC supernatants were studied for the presence of IL2. Such supernatants contain growth factor with physicochemical and biologic properties similar to the IL2 produced by Con A stimulated lymphocytes as described by Smith (26). Alloantigen primed lymphocytes obtained at 12 days of culture $\left(10^{6}\right.$ cells $\left./ \mathrm{ml}\right)$ were co-cultured with an equal number of 4000 rad X-irradiated original stimulator lymphocytes in $2 \mathrm{ml}$ cluster wells. After incubation for $24 \mathrm{hr}$, supernatants were harvested and were processed as described above.

Assays for IL2 activity, IL2 activity in culture supernatants of PHA activated T cells was determined by incubating test supernatants with IL2 dependent murine T cells (CTLL). Twofold serial dilutions of the IL2-containing test supernatants or commercially prepared rIL2 were added to microtiter wells containing $5 \times 10^{3}$ CTLL cells incubated in $0.2 \mathrm{ml}$ medium. Cultures were kept under standard conditions and ${ }^{3} \mathrm{H}$-TdR uptake was measured on day 2 . Because low quantities of IL2 could not be determined by this assay, the presence of IL2 activity in sec. MLC supernatants was assessed by the ability of these supernatants to support proliferation of alloantigen primed lymphocytes from 12 day bulk MLC. These cells start to proliferate when incubated with relatively small amounts of IL2 (27). Alloantigen primed lymphocytes, $10^{6}$ cells $/ \mathrm{ml}$, were dispensed into triplicate wells of microtiter plates in a volume of $0.1 \mathrm{ml}$. Graded quantities $(50 \%, 25 \%, 12.5 \%, 6.25 \%$, final culture concentration) of IL2 containing test supernatants or commercially prepared rIL2 were added to the wells in a volume of $0.1 \mathrm{ml}$. Cultures were kept under standard condi- 


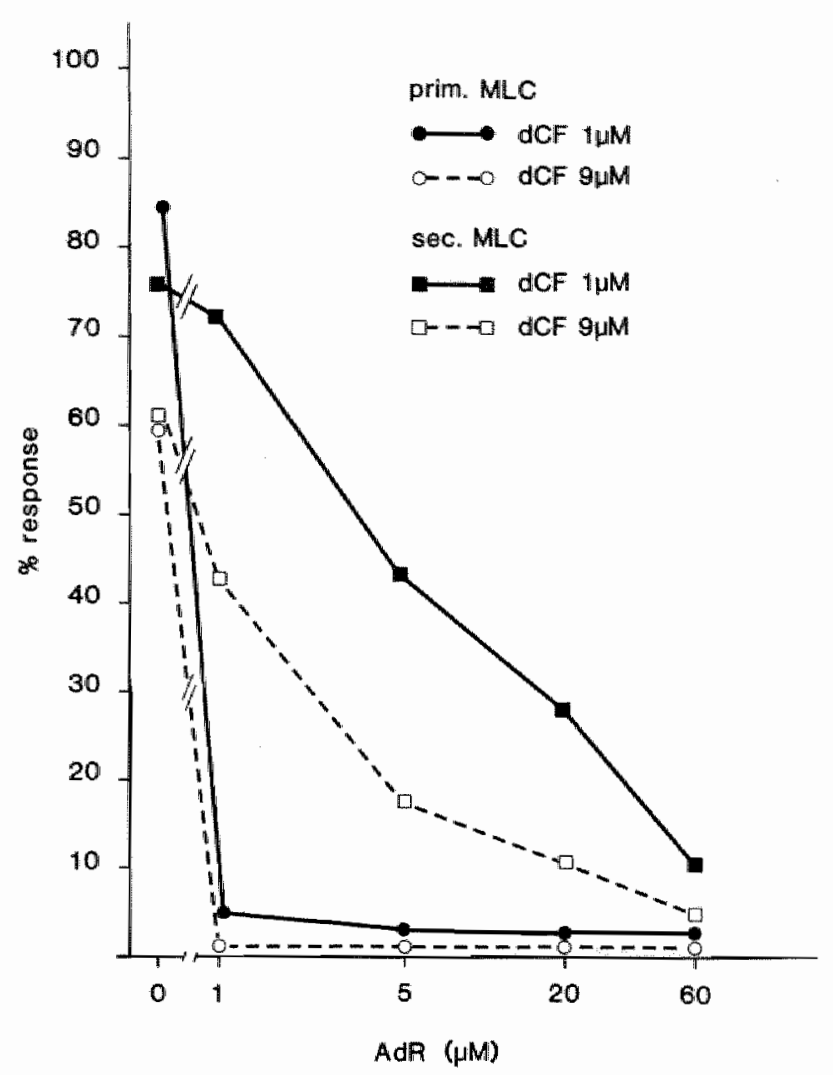

FIGURE 1. Inhibition of prim. MLC and sec. MLC by dCF and AdR. Different concentrations dCF and AdR were added at the initiation of culture. After 7 days (prim. MLC) and 3 days (sec. MLC), cultures were pulsed with ${ }^{3} H$-TdR. The results are given as percent relative proliferative response, which equals the ratio of ${ }^{3} H$-TdR uptake in the presence and $a b$ sence of the drugs $x 100 \%$. The data given are averages of 4 separate experiments. Each experiment was performed in triplicate. The control cultures (100\% response) ranged from 18,000 to $45,000 \mathrm{cpm}$ for prim. MLC and from 13,000 10 47,000 cpm for sec. MLC.

tions, and ${ }^{3} \mathrm{H}-\mathrm{TdR}$ uptake was measured on day 2 . All supernatants were dialyzed extensively against medium to remove AdR and dCF. IL2 activity was quantified by probit analysis of relations of the obtained counts per minute and the log of the dilution of supernatant to be tested, and was expressed in arbitrary units $(2.35 \mathrm{x}$ $10^{-2} \mu \mathrm{g}$ rIL2 was defined as 100 Units $\left./ \mathrm{ml}\right)$.

Antibodies, fluorescence staining. To determine the effect of $\mathrm{dCF}$ and $\mathrm{AdR}$ on IL2 receptor induction, either 12 day prim. MLC cells were restimulated with rIL2 or fresh peripheral blood cells were stimulated with PHA. At definite times after stimulation, cells were washed in phosphate-buffered saline (PBS) $+0.4 \%$ bovine serum albumin $+0.01 \%$ sodium azide and were incubated for half an hour at $4{ }^{\circ} \mathrm{C}$ 


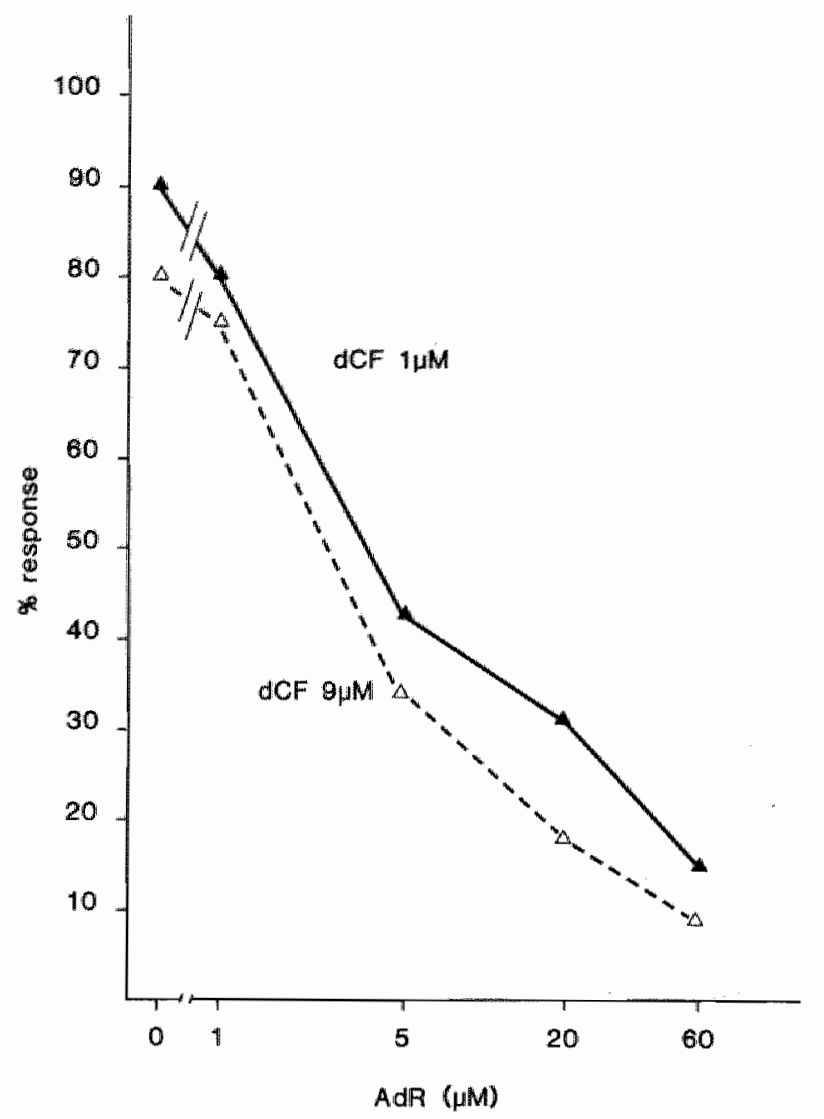

FIGURE 2. Inhibition of PHA response by dCF and AdR. Drugs were added at the initiation of culture. After 3 days, cultures were pulsed with ${ }^{3} \mathrm{H}-\mathrm{TdR}$ and were harvested. The results are expressed as percent relative proliferative response. The control cultures (100\% response) ranged from 65,000 to $75,000 \mathrm{cpm}$.

with a monoclonal antibody directed to the IL2 receptor (28). Cells were then incubated with fluorescein isothiocyanate-conjugated rabbit Ig anti-mouse Ig for 30 minutes at $4^{\circ} \mathrm{C}$. The cells were washed again and were examined by fluorescence microscopy and with a FACS IV (Becton Dickinson, Sunnyvale, CA). Monoclonal anti-1L2 receptor antibody was kindly provided by $\mathbb{H}$. Heyligen (Diepenbeek, Belgium).

\section{Results}

Differential sensitivity of dCF and AdR on alloantigen - and mitogen - induced proliferation. At the onset of the cultures, dCF and AdR were added at varying concentrations to prim. MLC, sec. MLC, and PHA response. Sensitivity of the 


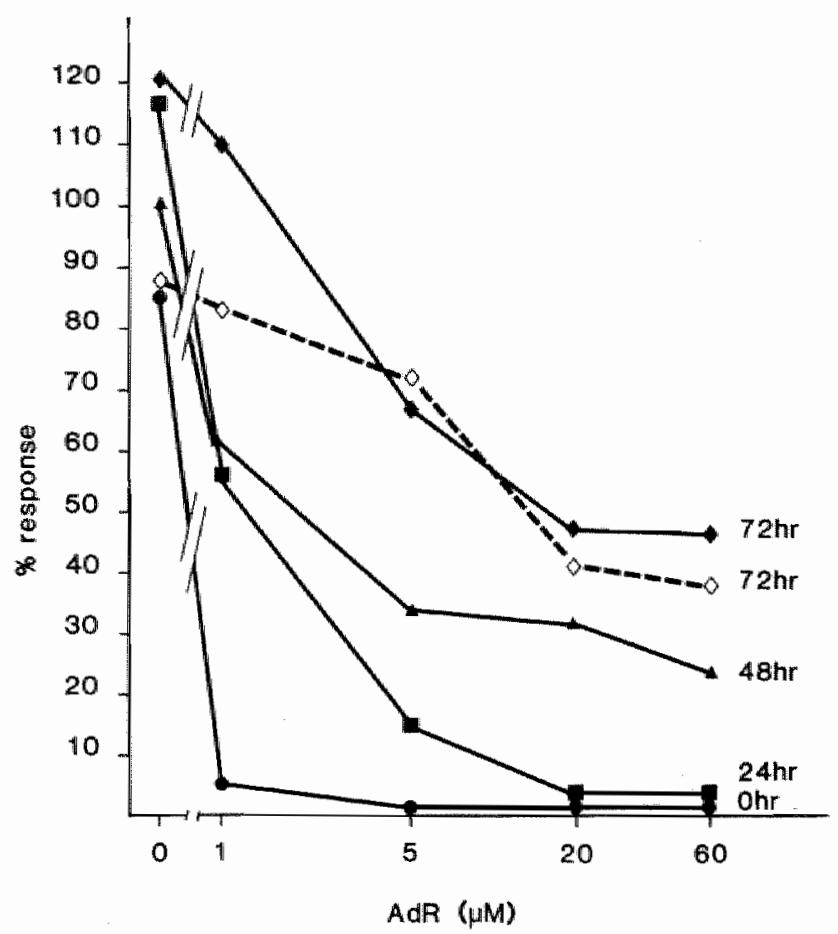

FIGURE 3. Early events in prim. MLC are most sensitive to the inhibitory effect of dCF and $A d R$. Different concentrations of $A d R$ combined with $I \mu M d C F$ or $9 \mu M d C F \ldots$ were added to prim. $M L C$ at the initiation of culture or at different times thereafter. ${ }^{3} \mathrm{H}$ $T d R$ uptake was determined after 7 days of culture. The results are expressed as percent relative proliferative response. The data shown are averages of 3 experiments, each performed in triplicate. The control cultures (100\% response) ranged from 20,000 to $45,000 \mathrm{cpm}$.

assays for both drugs was determined and was compared. The results summarized in Figures 1 and 2 show that prim. MLC was most sensitive to ADA inhibition. When ADA was blocked with $1 \mu \mathrm{M} d \mathrm{CF}$, the addition of $1 \mu \mathrm{M}$ AdR resulted in $>90 \%$ inhibition of cell proliferation in prim. MLC. Sec. MLC and PHA response were less sensitive to both drugs. For comparable inhibition in these assays, substantially higher concentrations of $\mathrm{AdR}$ or dCF were necessary. The differential sensitivity for $\mathrm{dCF}$ and $\mathrm{AdR}$ in the assays suggests that different mechanisms may be responsible for inhibition of proliferation. In the following experiments, mechanisms possibly involved in dCF and AdR toxicity are subjected to further study.

dCF and AdR interfere with cell activation. Because prim. MLC was most sensitive to ADA inhibition, we determined the influence of $\mathrm{dCF}$ and AdR on cell activation. For this purpose, dCF and AdR were added to prim. MLC at different times after initiation of culture $(0 \mathrm{hr}, 24 \mathrm{hr}, 48 \mathrm{hr}$, and $72 \mathrm{hr})$, and sensitivity to the drugs was determined in time course. The results, presented in Figure 3, show that when the drugs were added at the initiation of culture, the combination of $1 \mu \mathrm{M} \mathrm{dCF}$ and 


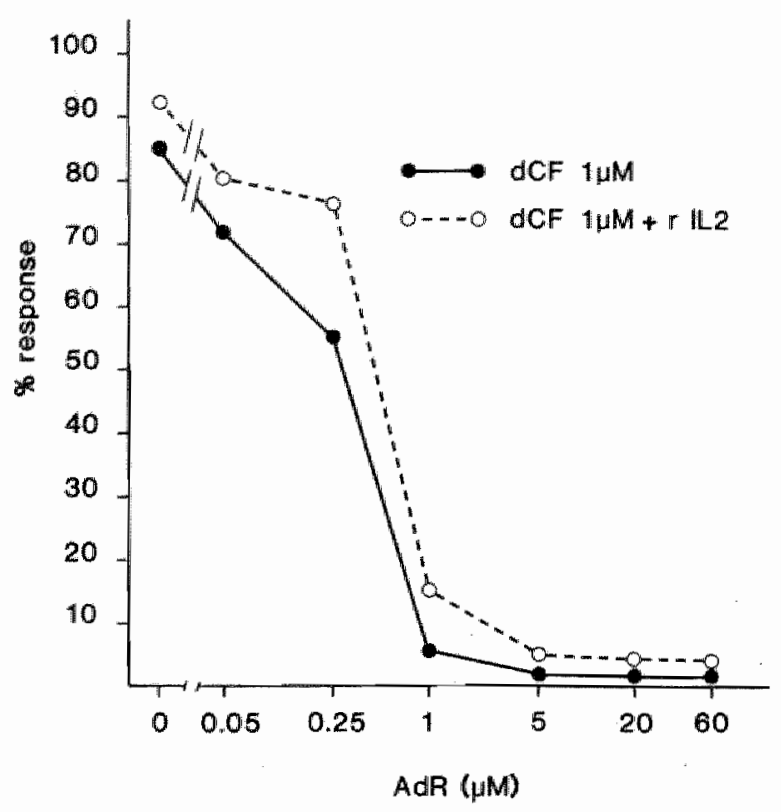

FIGURE 4. Exogenous rIL2 a'oes not abrogate the inhibitory effect of $d C F$ and $A d R$ in prim. $M L C$. Prim. MLC were performed with dCF and AdR alone, and in the presence of rIL2. When used, $r I L 2\left(2.5 \times 10^{-2} \mu \mathrm{g} / \mathrm{ml}\right)$ was added at the initiation of culture. Experiments contain dCF and AdR from the beginning. The data presented are averages of 3 experiments, each performed in triplicate. The control cultures (100\% response) ranged from 18,000 to $39,000 \mathrm{cpm}$ without rIL2 and from 40,000 to 85,000 with rIL2. In cultures without rIL2, the results are expressed as percent relative proliferative response:

${ }^{3} H$-TdR uprake cpm (with dCF + AdR) $\times 100 \%$.

${ }^{3} H$-TdR uptake cpm (without dCF and AdR)

In cultures with rIL2, the results are expressed as percent relative proliferative response which equals;

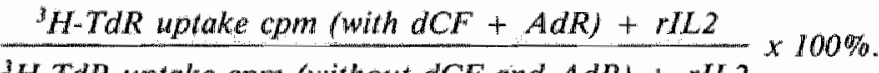

${ }^{3} \mathrm{H}$-TdR uptake cpm (without $d C F$ and $\left.A d R\right)+r I L 2$

$1 \mu \mathrm{M}$ AdR was sufficient for $>90 \%$ inhibition of cell proliferation. When dCF and AdR were added at $24 \mathrm{hr}$ or later, increasing quantities of $A d R$ were required for a substantial inhibition. These data indicate that $d C F$ and $A d R$ interfere early in the immune response and most likely prevent cell activation. This suggestion was confirmed when rIL2 was added to primary MLC. Quantities of rIL2 which normally induce cell proliferation in activated cells were not able to overcome the effect of dCF and AdR in prim. MLC (Fig. 4). These results confirm previous reports that early events within the $T$ cell activation process are most sensitive to ADA inhibition. However, the data also show that activated cells, cells to which dCF and AdR were added after initiation of culture, are not completely refractory to ADA inhibition, which confirms the results obtained in sec. MLC experiments. This finding 


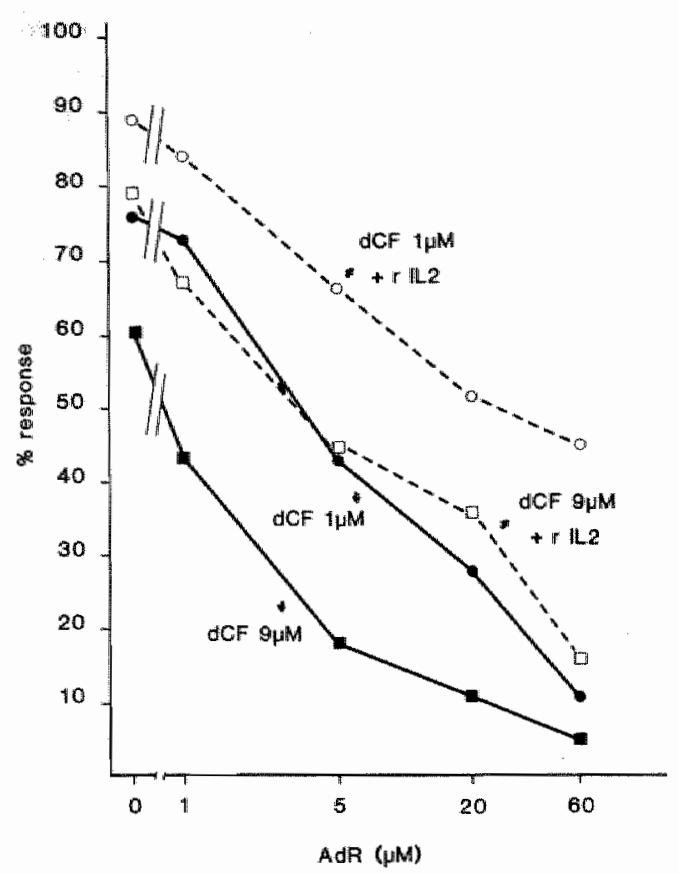

FIGURE 5. Exogenous rIL2 reduces the inhibitory effect of dCF and AdR in sec. MLC. Sec. $M L C$ were performed with $d C F$ and $A d R$ alone, and in the presence of $r I L 2$. When used, rIL2 $\left(2.5 \times 10^{-2} \mathrm{\mu g} / \mathrm{ml}\right)$ was added at the initiation of culture. Experiments contain dCF and AdR from the beginning. The data presented are averages of 3 experiments, each performed in triplicate. The control cultures (100\% response) ranged from 13,000 to 47,000 cpm without rIL2 and from 30,000 to 84,000 with rIL2. In cultures without rIL2, the results are expressed as percent relative proliferative response:

$\frac{{ }^{3} \mathrm{H}-\mathrm{TdR} \text { uptake cpm (with } d C F+A d R \text { ) }}{{ }^{3} H \text {-TdR uptake cpm (without } d C F \text { and } A d R \text { ) }} \times 100 \%$.

In cultures with $r L L 2$, the results are expressed as percent relative proliferative response which equals:

$\frac{\left.{ }^{3} H-T d R \text { uptake cpm (with } d C F+A d R\right)+r L L 2}{\left.{ }^{3} H-T d R \text { wptake cpm (without } d C F \text { and } A d R\right)+r L L 2} \times 100 \%$

means that besides interaction with cell activation, other mechanisms must be involved in dCF and AdR toxicity.

dCF and AdR inhibit IL2 production. To elucidate the effect of dCF and AdR on activated cells, we analyzed the inhibitory effects of these drugs on sec. MLC. Because IL2 production is an essential step in the induction of proliferation of already activated cells, we tested whether dCF and AdR inhibit sec. MLC via effects on IL2 production. First, we determined whether exogenous rIL2 would protect against dCF toxicity. The addition of rIL2 to sec. MLC partially reduced the inhibitory effect of dCF and AdR on cell proliferation (Fig. 5). The effect of rIL2 on cell 
proliferation was expressed as stimulation index: the ratio of ${ }^{3} \mathrm{H}-\mathrm{Td} \mathrm{R}$ uptake in the presence and absence of rIL2. The stimulation index (Table 1) rose with increasing concentrations of AdR, suggesting that IL2 production decreased with increasing concentrations of the drugs.

TABLE 1. Influence of IIL2 on sec. MLC in the absence and presence of $\mathrm{dCF}$ and $A d R^{\mathrm{I}}$

\begin{tabular}{|c|c|c|c|c|}
\hline \multicolumn{2}{|c|}{ Concentration } & \multirow{2}{*}{$\begin{array}{l}-\mathrm{rIL} 2 \\
(\mathrm{cpm})\end{array}$} & \multirow{2}{*}{$\begin{array}{l}+\mathrm{rlL} 2 \\
(\mathrm{cpm})\end{array}$} & \multirow{2}{*}{$\begin{array}{l}\text { Stimulation } \\
\text { Index rIL2 }\end{array}$} \\
\hline $\begin{array}{l}\mathrm{dCF} \\
(\mu \mathrm{M})\end{array}$ & $\begin{array}{l}\mathrm{AdR} \\
(\mu \mathrm{M})\end{array}$ & & & \\
\hline 0 & 0 & 15,379 & 66,820 & 4.3 \\
\hline 1 & 0 & 10,929 & 58,064 & 5.3 \\
\hline 1 & 1 & 10,152 & 57,465 & 5.7 \\
\hline 1 & 5 & 4,356 & 45,202 & 10.4 \\
\hline $\mathbb{1}$ & 20 & 2,451 & 32,891 & 13.4 \\
\hline 1 & 60 & 1.723 & 26,394 & 15.3 \\
\hline
\end{tabular}

- MLC cells obtained at day 12 of culture were restimulated with original stimulator cells in the absence or presence of $r I L 2\left(2.5 \times 10^{-2} \mu \mathrm{g} / \mathrm{ml}\right)$. Different concentrations $\mathrm{CCF}$ and AdR were added at the initiation of culture. The effect of $r I L 2$ an cell proliferation is expressed as stimulation index:

${ }^{3} H$-TdR uptake cpm in the presence of $r 1 L 2$

${ }^{3} H$-TdR uptake cpm in the absence of $r L 2$

The data show a representative experiment from a series of 3 .

Subsequently, we measured the production of IL2 in sec. MLC. It was observed that concentrations of $\mathrm{dCF}$ and AdR which completely inhibit the proliferative response also clearly inhibit IL2 production (Table 2). Thus, it can be concluded that one of the contributing effects of $\mathrm{dCF}$ and AdR on activated cells is the inhibitory effect on the production of IL2. However, this could not be the only mechanism because there is still an inhibitory effect left after rIL2 is added to sec. MLC. This means that also IL2 driven proliferation is inhibited by these drugs. We therefore tested whether in activated cells IL2 receptor expression was affected by dCF and AdR.

dCF and AdR inhibit IL2 receptor expression. It has been reported that IL2 added to activated $T$ cells enhances the expression of IL2 receptors (29) and induces prolliferation. To investigate the direct effect of dCF and AdR on IL2 receptor induction, we added rIL2 to 12 day prim. MLC cells, and IL2 receptor expression was determined in the days after stimulation (Fig. 6). The presence of dCF and AdR reduced the fraction of cells carrying IL2 receptors and the density of receptors (data not given). On day 3 after stimulation, 34\% of the cells in control cultures showed IL2 receptor expression, whereas in cultures treated with $\mathrm{dCF}$ and AdR, 
TABLE 2. Inhibition of IL2 production by dCF and AdR

\begin{tabular}{lll}
\hline Concentration & $\begin{array}{l}\text { Sec. MLC } \\
(\mathrm{U} / \mathrm{ml})\end{array}$ & $\begin{array}{l}\text { PHA Response } \\
\text { (U/m) }\end{array}$ \\
\hline No drugs added & 10 & 170 \\
$1 \mu \mathrm{M} \mathrm{dCF}+20 \mu \mathrm{M}$ AdR & - & 170 \\
$9 \mu \mathrm{M} \mathrm{dCF}+60 \mu \mathrm{M}$ AdR & 3.3 & 200 \\
\hline
\end{tabular}

- MLC cells were restimulated with original stimulator cells in the absence or presence of $d C F$ and AdR. After $24 \mathrm{hr}$, supernatants were collected to determine IL 2 content. Supernatants were dialyzed against RPMT to remove $d C F$ and $A d R$, and were subsequently tested on 12-day prim. MLC cells.

PHA responses were performed as described. After $24 \mathrm{hr}$, supernatants were collected from the cultures and were dialyzed. Supernatants were tested for IL2 activity with IL2. dependent murine $T$ cells (CTLL). IL2 activity was expressed in arbitrary units.

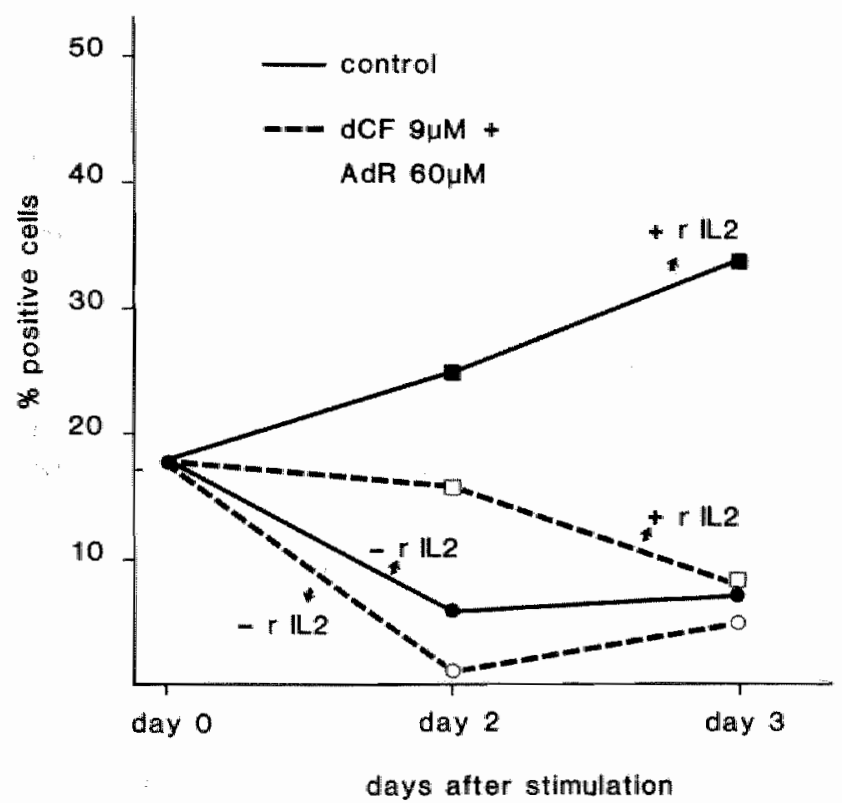

FIGURE 6. Inhibition of the induction of $I L 2$ receptor expression by dDF and $A d R$ on day 12 prim. $M L C$ cells in response to $r L L 2$. To induce $I L 2$ receptor expression, $r I L 2$ was added to 12-day prim. MLC cells. IL2 receptor expression was determined by immunofluorescence with monoclonal antibody directed against IL2 recepior. IL2 receptor expression was measured before stimulation (day 0 ) and on days 2 and 3 thereafter. In the absence of $d C F$ and AdR, cullures stimulated with $r I L 2$ showed $a{ }^{3} \mathrm{H}$-TdR uptake of $14,000 \mathrm{cpm}$ on day 3. In cultures stimulated with $\mathrm{rLL} 2$ in the presence of $d C F(9 \mu M)$ and $A d R(60 \mu M),{ }^{3} \mathrm{H}-\mathrm{TdR}$ uptake on day 3 was 1,200 cpm. IL2 receptor induction and cell prolfferation were absent in cells that did not receive $r I L 2$. 


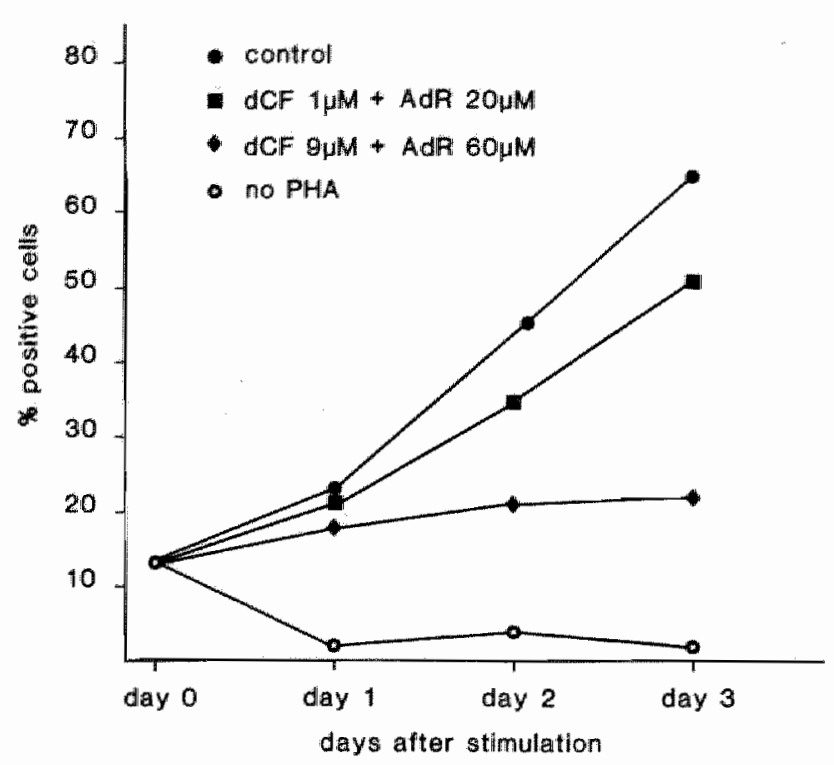

FIGURE 7.Imhibition of IL2 receptor induction by dCF and AdR in PHA stimulated cells. Peripheral blood mononuclear cells were stimulated with PHA, and IL2 receptor expression was determined before stimulation (day 0) and on the following days thereafter. Cultures were untreated or received dCF and AdR at the intiation of culture.

only $8 \%$ of the cells showed IL2 receptor expression. In untreated cultures, a clear proliferative response was observed, whereas in cultures treated with $\mathrm{dCF}$ and $\mathrm{AdR}$, sensitivity for IL2 was strongly reduced and proliferation was negligible. Therefore, it appears that besides inhibition of IL2 production, dCF and AdR also extend their effect on activated cells via inhibition of IL2 receptor expression.

Lectin stimulation versus alloantigen stimulation. The influence of $\mathrm{dCF}$ and $\mathrm{AdR}$ on PHA induced proliferation was studied. It appeared that IL2 production in PHA response was not inhibited by $\mathrm{dCF}$ and AdR (Table 2). Even doses which clearly inhibit proliferation did not affect IL2 production. These findings show that cell activation had taken place during dCF and AdR treatment. However, IL2 receptor induction was markedly inhibited during treatment with the drugs (Fig. 7). At a concentration of $9 \mu \mathrm{M} \mathrm{dCF}$ and $60 \mu \mathrm{M}$ AdR, $22 \%$ of the cells showed IL2 receptor expression on day 3 as compared with $65 \%$ of the cells cultured in the absence of dCF and AdR. This finding, which is in agreement with the observation made after the addition of rIL2 to 12 day prim. MLC cells, suggests that inhibition of PHA induced proliferation by dCF and AdR is due to interference with IL2 receptor induction. 


\section{Discussion}

The data presented here show that dCF and AdR affect several events in allogeneic $T$ cellular immune response. Cell activation appeared to be most sensitive to the drugs. Prim. MLC response was completely inhibited by concentrations as low as $1 \mu \mathrm{M} \mathrm{dCF}$ and $1 \mu \mathrm{M} \mathrm{AdR}$, whereas these concentrations were less effective when added to activated cells. Furthermore, rIL2 was not able to abrogate the inhibitory effect of dCF and AdR on prim. MLC. This finding suggests that early events within the cell activation process are blocked because rIL 2 added to allogeneically activated cells resulted in a clear proliferative response, which was not substantially inhibited by such low concentrations of dCF and AdR. Our data confirm other reports that early events in the $T$ cell activation process are most sensitive to ADA inhibition (15, 19,20). Apart from cell activation, $\mathrm{dCF}$ and $\mathrm{AdR}$ interfere also with proliferation of activated cells. Two events in activated lymphocytes are affected: IL2 production and $I L 2$ receptor expression. In sec. MLC, we observed that IL2 production was markedly inhibited by $\mathrm{dCF}$ and AdR. The addition of rIL2 to these cultures, however, could only partially abrogate the inhibitory effect of the drugs. This finding is consistent with the observation that $\mathrm{dCF}$ and AdR directly affected IL2 receptor expression. The combined interaction with IL2 receptor expression and IL2 production results in effective inhibition of cell proliferation of activated cells. These data confirm earlier observations $(15,20)$ that activated cells are not refractory to dCF and AdR, as suggested by other investigators $(19,30)$.

It has been proposed that dCF and AdR inhibit RNA synthesis early in the cell cycle before DNA is synthesized $(15,31)$. In concordance, we observed that in activated T cells, high doses of $\mathrm{dCF}$ and AdR induce inhibition of IL2 production and IL2 receptor induction. The data obtained in prim. MLC suggest, however, that dCF and AdR may also exert an effect before RNA synthesis, because in this assay low concentrations of $\mathrm{dCF}$ and $\mathrm{AdR}$ already resulted in complete inhibition of the response. Because AdR is known to inhibit protein kinase activity (32), and the activation of thymocytes (and also macrophages) is known to be associated with changes in cAMP dependent protein kinases $(33,34)$, it appears that interactions between AdR and protein kinase activity within lymphocytes could be the mechanism by which $\mathrm{dCF}$ and AdR interfere with cell activation even before RNA synthesis is induced. Regarding activated $T$ cells, our findings extend earlier reports by demonstrating that in these cells, inhibition of IL2 production and IL2 receptor expression may represent mechanisms by which $\mathrm{dCF}$ and AdR interfere with cell proliferation. Lectin stimulation led to data slightly different from results obtained with allostimulation. In PHA stimulated cultures, high concentrations of $\mathrm{dCF}$ and AdR resulted in complete inhibition of cell proliferation, whereas IL2 production was normal, which confirms a previous report by Redelman et al. (15). The data show clearly that cell activation occurred after PHA stimulation. In these cells, however, inhibition of IL2 receptor expression resulted in IL2-insensitive cells and complete inhibition of proliferation. Differences in IL2 receptor expression between untreated cul- 
tures and cultures treated with $\mathrm{dCF}$ and $\mathrm{AdR}$ were not present at $24 \mathrm{~h}$ after stimulation as reported (15), but were shown to appear at $48 \mathrm{hr}$ of culture. Further studies are necessary to obtain quantitative data on IL2 receptor density and the ratio between high- and low-affinity IL2 receptors, because a reduced ratio of high- to lowaffinity receptors could explain the data observed.

Two main differences were observed between the effects of $\mathrm{dCF}$ and $\mathrm{AdR}$ on lectin and allogeneic cell stimulation: 1) $\mathrm{T}$ cell activation was inhibited in prim. MLC at low concentrations, whereas in PHA stimulation $T$ cell activation was not inhibited: 2) in allogeneic cell stimulation, a clear effect on IL2 production was observed which was not present in PHA stimulation. Both phenomena might be explained by the difference in intensity of stimulation brought about by the lectin PHA, compared with allogeneic stimulation. The fact that IL2 production was inhibited by $\mathrm{dCF}$ and $A d R$ in rat thymocytes stimulated with the weaker lectin Con A (21) fits this postulation. However, both in PHA stimulated and allogeneic stimulated cells, IL2 receptor expression was inhibited.

In rats, we showed that $\mathrm{dCF}$ is a very effective immunosuppressive drug with a potency comparable to Cyclosporin A (9). In this study, we report that in allogeneic cell stimulation, inhibition of ADA interferes with cell activation, IL2 production, and IL 2 receptor expression. In this respect, inhibition of the enzyme ADA resembles the action of well-known immunosuppressive drugs; Cyclosporin $\mathrm{A}$ and steroids also affect cell activation and lymphokine production $(27,35-38)$. However, the advantage of ADA inhibition above other immunosuppressive drugs is determined by its lymphospecific effect. The induction of specific lymphocytotoxicity is an attractive approach to clinical immunosuppression. Antithymocyte globulin (ATG) and anti-CD3 antibodies prove to be potent immunosuppressive drugs which are selectively toxic for lymphocytes (39-44). Side effects of ATG and antibody response to anti-CD3 antibodies, however, often limit the clinical value of these agents. The inhibition of the enzyme ADA may be an alternative approach to induce specific immunosuppression. Inhibition of ADA is achieved with doses of 0.25 to $1 \mathrm{mg} / \mathrm{kg}$ body weight per day in man as well as in rats $(45,46)$. In rats, these doses of dCF result in effective immunosuppression, as demonstrated by prolonged skin graft survival and impaired mitogen-induced proliferation (8). In man, ADA inhibitors have been used in patients with lymphoproliferative malignancies (45). In these patients, low doses of $\mathrm{dCF}$, which showed a therapeutic effect, were safe and tolerable. At high doses, neurotoxicity and nephrotoxicity were observed, the latter mostly in patients with prior renal impairment. In these patients, with a large tumor load, tumor degradation products inevitably played an important role in the toxic effects described. Further investigations are necessary to determine the effectiveness and safety of ADA inhibitors as immunosuppressive drugs.

At present, the only 'cure' for congenital ADA deficiency is a bone marrow transplantation from a histocompatible donor (4). In the majority of cases, a suitable donor cannot be found, and the only alternative for such patients is repeated transfusions with ADA-positive erythrocytes. It was suggested that administration of ex- 
ogenous IL2 to ADA-deficient patients could prove useful in association with red blood cell transfusions (21). However, our data demonstrate that the in vitro addition of rIL2 to prim. MLC cannot restore cell proliferation. Moreover, it was shown that a state of ADA deficiency inhibits IL2 receptor expression. According to these results, it is doubtful whether administration of exogenous IL2 to these patients can be of benefit.

Acknowledgments. This work was supported by the Dr. Saal van Zwwanenbergstichting. We thank Dr. J. Douros of the National Cancer Institute U.S.A. for generously providing the dCF, and Mrs. K. Spronck for the superb secretarial assistance.

Abbreviations used in this paper: $A D A$, adenosine deaminase; $d C F, 2^{3}$ deoxycoformycin; AdR, deoxyadenosine; dATP, deoxyadenosine triphosphate; MLC, mixed lymphocyte culture; prim. MLC, primary MLC; sec. MLC, secondary MLC; PHA, phytohemagglutinin; IL2, interleukin 2; Con A, concanavalin A; rIL2, human recombinant interleukin 2 ; FACS, Fluorescence-activated cell sorter; ATG, antithymocyte globulin.

\section{References}

1. Gibleti, E.R., J.E. Anderson, F. Cohen, B. Pollara, and H.J. Meuwissen. 1972. Adenosine deaminase deficiency in two patients with severely impaired cellular immunity. Lancet 2: 1067 .

2. Dissing, J., and B. Knudsen. 1972. Adenosine deaminase deficiency and combined immunodeficiency syndrome. Lancet $2: 1316$.

3. Meuwissen, H.J., B. Pollara, and R.J. Pickering. 1975. Combined immunodeficiency disease associated with adenosine deaminase deficiency. J. Pediatr. 86: 169.

4. Thompson, L.F, and J.E. Seegmiller. 1980. Adenosine deaminase deficiency and severe combined iimmunodeficiency disease. Adw. Enzymol. 51: 167.

5. Tedde A., M.E. Ballis, S. Ikehara, R. Pahwa, R.A. Good, and P.P. Trotta. 1980. Animal model for immune dysfunction associated with ademosine deaminase deficiency. Proc. Natl. Acad. Sci. USA 77: 4899 .

6. Sordillo, E.M., S. Ikehara, R.A. Good, and P.P. Trotta. 1981. Immunosuppression by

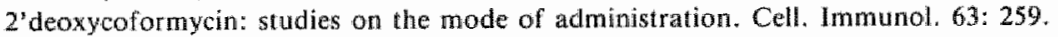

7. Trotta, P.P., A. Tedde, S. Ikelvara, R. Pahwa, R.A. Good, and M.E. Balis. 1981. Specific immunosuppressive effects of constant infusion of 2'deoxycoformycin. Cancer Res. $41: 2189$.

8. Ruers, T.J.M., W.A. Butrman, C.J. van der Linden, and G. Kootstra. 1985. Complete suppression of skin allograft rejection in rats treated with continuous infusion of 2 "deoxycoformycin. Transplantation $40: 137$.

9. Ruers, T.J.M., C.J. van der Linden, W.A. Buurman, and G. Kootstra. 1985. 2"deoxycoformycin: a new immunosuppressive drug with a potency comparable to Cyclosporine. Transplant. Proc. XVII: 1333 .

10. Carson, D.A., J. Kaye, and J.E. Seegmiller. 1977 . Lymphospecific toxicity in adenosine deaminase deficiency and purine nucleoside phosphorylase deficiency: possible role of nucleoside kinase(s). Proc. Natl. Acad. Sci. USA 74: 5677. 
11. Carson, D.A. J. Kaye, and J.E. Seegmiller. 1978. Differential sensitivity of human leukemic $T$ cel1 lines and B cell lines to growth inhibition by deoxyadenosine. In Immonol. 121: 1726.

12. Mitchell, B.S., E. Mejias, P.E. Daddona, and W.N. Kelley. 1978. Purinogenic immunodeficiency diseases: selective toxicity of deoxyribonucleosides for T cells. Proc. Nath. Acad. Sci. USA 75: 5011 .

13. Mitchell, B.S., and W.N. Kelley. 1980. Purinogenic immunodeficiency diseases: clinical features and molecular mechanisms. Ann. Intern. Med. 92: 826 .

14. Albert, D.A., D. Redelman, and H.G. Bluestein. 1981. Deoxyadenosine toxicity in human and mouse lymphocytes: silmillarities and contrasts. Fed. Proc. 40: 1081.

15. Redelman, D., H.G. Bluestein, A.H. Cohen, J.M. Depper and S. Wormsley. 1984. Deoxyadenosine (AdR) inhibition of newly activated lymphocytes: Blockade at the G0-GI interface. J. Immuriol. 132:2030.

16. Brox, L.W, E. Pollock, and A. Belch. 1982. Adenosine and deoxyadenosine toxicity in colony assay systems for human T lymphocytes, B lymphocytes and granulocytes. Car. Chem. Pharmacol. 9: 49 .

17. Hovi, T., J.F. Smyth, A.C. Allison, and S.C. Williams. 1976. Role of adenosine deaminase in lymphocyte proliferation. Clin. Exp. Immunol. 23: 395.

18. Burridge, P.W., V. Paetkau, and J.F. Henderson.. 1977. Studies of the relationship between adenosine deaminase and immune function. J. Immunol. 119: 675.

19. Kotb, M., and B.C. Veit. 1982. Activated T lymphocytes resist the toxic effects of adenosine deaminase inhibitor 2 'deoxycoformycin. Cell. Immunol. 72:64.

20. Uberti, J., J.J. Lightbody, and $\mathbb{R}$.M. Johnson. 1979. The effect of nucleosides and deoxycoformycin on adenosine and deoxyadenosine inhibition of human lymphocyte activation. J. Immunol. 123: 189.

21. Thuillier, $L_{\ldots}, F$. Garreau, and P. Cartier. 1981. Inability of immunocompetent thymocytes to produce $T$ cell growth factor under adenosine deaminase deficiency conditions. Cell inmunol. 63 : 81.

22. Cohen, A., R. Hirschhorn, S. Horowitz, A. Rubinstein, S.H. Polmar, R. Hong, and D. W. Martin. 1978. Deoxyadenosine triphosphate as a potentially toxic metabolite in adenosine deaminase deficiency. Proc. Natl. Acadl, Sci. USA 75: 472.

23. Tattersall, M.H.N., K. Ganeshaguru, and A.V. Hoffbrand. 1975. The effect of external deoxyribonucleosides and deoxyribonucleoside triphosphate concentrations in human lymphocytes. Biochem. Pharmacol. 24: 1495.

24. Lowe, J.K., B. Gowans, and L. Brox. 1977. Deoxyadenosine metabolism and toxicity in cultured L5178Y cells. Cancer Res. 37: 3013.

25. Polmar, S.H., R.C. Stern, A.L. Schwartz, E.M. Wetzler, P.A. Chase, and R. Hirschhorn, 1976. Enzyme replacement therapy for adenosine deaminase deficiency and severe combined immunodeficiency. N. Engl. J. Med. 295: 1337.

26. Smith, K.A. 1980. T-cell growth factor. Immunol. Rev, 51: 337.

27. Hess, A.D., P.J. Tutschka, and G.W. Santos. 1982. III CsA inhibits the production of T lymphocyte growth factors in secondary mixed lymphocyte responses but does not inhibit the response of primed lymphocytes to TCGF. J. Immunol. $128: 355$.

28. Heyligen, H., W. Weber, E. Bosmans, and J. Raus. 1985. A monoclonal antibody detecting human $T$ cell activation antigens. Fed. Proc. 44: 787.

29. Reem, $\mathrm{O} . \mathrm{H}$, and $\mathrm{N} . \mathrm{H}$. Yeh. 1984. Interleukin 2 regulates the expression of its receptor and the synthesis of gamma interferon by human T cells. Science 225: 429 .

30. Ballet, J.J., R. Insel, E. Merler, and F.S. Rosen, 1976. Inhibition of maturation of human precursor lymphocytes by coformycin, an inhibitor of the enzyme adenosine deaminase. J. Exp. Med. 143: 1271.

31. Matsumoto, S.S., J. Yu, and A.L. Yu. 1983. Inhibition of RNA synthesis by deoxyadenosine plus deoxycoformycin in resting lymphocytes. J. Immunol. 131: 2762.

32. Kariya, T., and J.B. Field. 1976. Erfects of adenosine and its derivatives on protein kinase activity of beef thyroid. Biochim. Biophys. Acta 451: 41.

33. Mednieks, M.1., and R.A. Jungmann. 1982. Selective expression of type I and type II cyclic AMPdependent protein kinases in subcellular fractions of concanavalin A-stimulated rat thymocytes. Arch. Biochem. Biophys. 213: 127. 
34. Justement, L.B., W.A. Aldrich, G.D. Wenger, M.S. O'Dorisio, and B.S. Zwilling. 1986. Modulation of cyclic AMP dependent protein kinase isozyme expression associated with activation of a macrophage cell line. J. Immunol. 136: 270.

35. Elliott, J.F., Y. Lin, S.B. Mizel, R.C. Bleackley, D. G. Harnish, and V. Paetkau. 1984. Induction of interleukin 2 messenger RNA inhibited by Cyclosporin A. Science 226: 1439.

36. Gillis, S., G.R. Crabtree, and K.A. Smith. 1979. Glucocorticoid-induced inhibition of T cell growth factor production. I. The effect on mitogen-induced lymphocyte proliferation. I. Immunol. 123: 1624 .

37. Larsson, E.L. 1980. Cyclosporin A and dexamethasone suppress $T$ cell responses by selectively acting at distinct sites of the triggering process. J. Immunol. 124: 2828 .

38. Arya, S.K., F. Wong-Staal, and R.C. Gallo. 1984. Dexamethasone-mediated inhibition of human T cell growth factor and gamma-interferon messenger RNA. J. Immunol. 133: 273.

39. Shield, C.F., A.B. Cosimi, N. Tolkoff-Rubin, R.H. Rubin, J. Herrin, and P.S. Russell. 1979. Use of antithymocyte globulin for reversal of acute allograft rejection. Transplantation 28: 461 .

40. Streem, S.B., A.C. Nowick, W.E. Braun, D. Steinmuller, and R. Greenstreet. 1983. Low-dose maintenance prednisone and anti lynphoblast globulin for the treatment of acute rejection. Transplantation 35: 420.

41. Hoitsma, A.J., H.J.J. van Lier, P. Reekers, and R.A.P. Koene. 1985. Improved patient and graft survival after treatment of acute rejections of cadaveric renal allografts with rabbit antithymocyte globulin. Transplantation 39: 274 .

42. Cosim, A.B., R.C. Burton, R.B. Colvin, and G. Goldstein et al. 1981. Treatment of acute renal allograft rejection with OKT3 monoclonal antibody. Transplantation 32: 535 .

43. Norman, D.J., J.M. Barry, K. Henell, M.B. Funell, G. Goldstein, and L. Bohannon. 1985. Reversal of acute allograft rejection with monoclonal antibody. Transplant. Proc. XVII: 39.

44. Kreis, H., and $\mathrm{G}$. Goldstein. 1985. Monoclonal antibodies for the treatment of acute rejection episodes in renal transplantation. Transplant. Proc. XVII: 2751.

45. Anmual report to the Food and Drug Administration on deoxycoformycin and ARA-A. National Cancer Institute, October 1983.

46. Chassin, M.M., R.H. Adamson, D.W. Zaharevitz, and D.G. Johns. 1979. Enzyme inhibition titration assay for 2 deoxycoformycin and its application to the study of the relationship between drug concentration and tissue adenosine deaminase in dogs and rats. Biochem. Pharmacol. $28: 1849$. 
Studies on selective immunosuppression by local treatment of the allograft 


\section{Study 4}

\section{Local treatment of renal allografts, a promising way to reduce the dosage of immunosuppressive drugs.}

Published in Transplantation 1986; 41: 156.

\section{Summary}

A method is described for continuous administration of immunosuppressive drugs directly into rat renal allografts. The drug is given via a catheter, introduced into the suprarenal or testicular artery of the transplanted kidney. The cannula is connected to an implantable osmotic minipump that delivers an immunosuppressive drug with continuous flow for $\mathbb{1 3}$ days. It is demonstrated that the technique as such has no detrimental or enhancing effects on renal allograft survival. Depending upon the pharmacokinetic properties of the drug administered, this technique allowis a more or less selective treatment of renal allograft rejection.

The method was used to test the effect of intrarenal administration of prednisolone on renal allograft survival. Intrarenal administration of this drug appeared to be superior to any other way of administration tested. A low dose of $4 \mathrm{mg} / \mathrm{kg}$ body weight per day given by continuous intrarenal infusion results in significant prolongation of graft survival, whereas continuous systemic administration of this dose is not effective. To induce prolongation of graft survival by intraperitoneal administration the prednisolone dose had at least to be doubled. The results prove that during graft rejection local events within the graft are vulnerable to prednisolone. It is concluded that local treatment of allograft rejection is possible and that this approach represents a potentially important way to manipulate the immune response. 


\section{Introduction}

In rats, a method was developed for local drug delivery into the renal artery of a transplanted kidney (further called intrarenal or local drug delivery). Thus it became possible to deliver immunosuppressive drugs directly to the renal allograft. The technique was derived from chronic local drug infusion into the renal artery of unrestrained rats as described earlier (1). Depending upon the pharmacokinetic properties of the drug used, this approach allows a more or less selective treatment of the transplanted kidney. More precisely, intrarenal drug delivery results in high renal exposure of the drug with low systemic exposure, if total body clearance of the drug is high or the extraction ratio by the kidney is high.

Local events within the kidney play an important role during the afferent, as well as during the efferent, phase of the immune response (2-8). When selective administration of immunosuppressive drugs to renal allografts can interfere with these processes, allograft rejection may be manipulated locally. This approach to immunosuppressive therapy offers interesting perspectives because reduced systemic drug levels lead to fewer systemic side effects of the immunosuppressive agents used. We have tested the effect of local administration of prednisolone on renal allograft survival since the plasma half-life of prednisolone in the rat is short (9). The results are compared to those obtained with prednisolone administered by other routes. It is demonstrated that local continuous infusion of prednisolone is an effective way to induce immunosuppression. It appeared to be superior to any other way of administration tested.

\section{Materials and methods}

Animals. Inbred male Brown Norway $\left(\mathrm{RT}^{\mathrm{n}}\right)$ and Lewis rats $\left(\mathrm{RT}^{\mathrm{L}}\right)$ were obtained from the department of experimental animal services of the University of Limburg. Rats of 250 to $300 \mathrm{~g}$ were used for all experiments. Rats were supplied with acidified water and rat chow ad libitum.

Kidney transplantation. Kidneys were transplanted from Brown Norway (BN) rats to Lewis rats. In $\mathrm{BN}$ rats the right renal artery gives off the suprarenal artery or the testicular artery. Both arteries can be used for catheter implantation. Therefore only right donor kidneys were used. Renal allografting was performed according to the technique of Lee (10) with the modifications of Lameyer (11) for the urether bladder anastomosis.

Both recipient kidneys were removed during operation and graft survival was assessed by animal survival. Serum urea levels were determined on day 3, day 7 , and at weekly intervals thereafter. Urea concentrations were measured using an urease colorimetric assay (Boehringer, Mannheim, FRG). Serum urea levels in normal animals were $50-55 \mathrm{mg} / 100 \mathrm{ml}$. Recipients were killed on the 50 th day after transplantation if rejection had not occurred. 


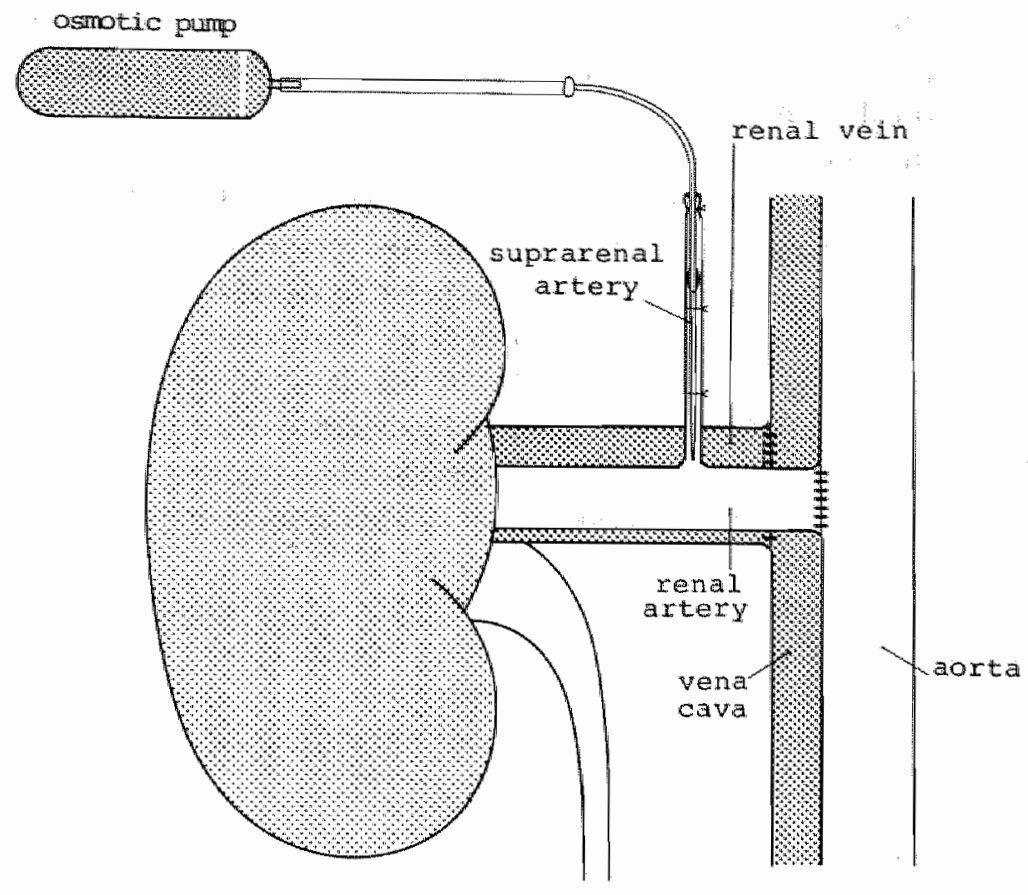

FIGURE 1. Schematic outline of the experimental model used for drug infusion into the renal artery of a transplanted kidney. A catheter is introduced into the suprarenal (or testicular) artery of the transplanted kidney and connected to an asmotic minipump implanted in the abdominal cavity. The osmotic minipump delivers the drug in a continuous fashion from day 0 until day 13.

Technique of intrarenal and intravenous drug delivery. For intrarenal treatment a catheter was introduced in the suprarenal or testicular artery of the transplanted kidney in a way similar to that previously described in normal rats (1) (Figure 1). The catheter was secured to the vessel, preventing the tip of the cannula from protruding into the arterial lumen. After patency of the infusion system was checked, the catheter was immediately connected to the pump.

Catheters were constructed of a $10 \mathrm{~cm}$ piece of polyethylene (PE)-10 tubing (Clay Adams, Parsippany, NJ). The tip of the catheter was stretched over a hot soldering iron to reduce its outer diameter to approximately $0.2 \mathrm{~mm}$. An inner diameter of $0.1 \mathrm{~mm}$ was maintained by the previous introduction of a steel wire of that diameter. The catheter was extended by a $5 \mathrm{~cm}$ piece of PE-60 Tubing (Clay Adams) which was heat-sealed to the PE-10 tubing (1).

For intravenous drug delivery a Silastic catheter (602-155 Silastic tubing Dow Corning, Midland, MI) was introduced into the jugular vein, guided to the abdominal cavity, and connected to the osmotic minipump. 
Drug administration. Prednisolone was given by means of continuous infusion intrarenally, intravenously (iv) or intraperitoneally (ip). Administration of prednisolone ip was also performed by bolus injection once daily.

Continuous delivery of prednisolone was performed with Alzet osmotic minipumps (model 2ML2, Alza, Palo Alto, CA). The pumps were implanted in the abdominal cavity immediately after transplantation. Pumps delivered prednisolone directly into the abdominal cavity or were connected to a catheter to deliver the drug intrarenally or iv. In this way prednisolone was delivered ip, intrarenally, or iv at a constant rate of approximately $6 \mu \mathrm{l} / \mathrm{hr}$ from day 0 till day 13 . Prednisolone (Nogepha, Alkmaar, The Netherlands) was dissolved in pyrogen-free distilled water without heparin, and the dose of the drug was adjusted to the body weight of the recipient at day $\mathbf{- 1}$. In animals that received intrarenal or iv treatment correct position of the catheter was checked at autopsy.

Rats, treated with ip bolus injections were injected once daily. Solutions were prepared at day -1 and kept at $37^{\circ} \mathrm{C}$ in order to permit comparison of results with those obtained with continuous infusion. The dose of prednisolone was adjusted to the body weight of the recipient at day -1 and remained constant during the experiment. Drug administration started on day -1 and lasted till day 13 .

Statistical analysis. Comparisons between groups were made using the Wilcoxon rank test. Differences were considered to be statistically significant if $p<0.05$ in a two-tailed test.

\section{Results}

To test the effect of the intrarenal infusion technique on graft survival Lewis recipients were untreated or received continuous intrarenal infusion with saline. The results, shown in Table 1, demonstrate that the intrarenal infusion technique has no influence on renal allograft survival. Median survival time (MST) in animals treated with continuous intrarenal infusion was 7 days, which did not significantly differ from the MST observed in untreated rats. To evaluate the function of renal allografts during intrarenal infusion, early graft function was determined by estimating serum urea levels on day 3 posttransplant (Table 1). Untreated rats and salinetreated rats showed similar serum urea levels, which indicates that the technique of intrarenal infusion does not interfere with early graft function. From these observations it can be concluded that the intrarenal infusion technique has neither detrimental nor enhancing effects on renal allograft survival.

To study the effect of intrarenal prednisolone therapy on renal allograft survival various prednisolone treatments were tested. Prednisolone was administered in four ways and dose-response studies were performed to establish the optimal regimen of administration. The drug was given by continuous infusion (intrarenal, iv or ip) or by ip bollus-injections. The results of these experiments are given in Table 2 . 
TABLE 1. Effect of the intrarenal infusion technique upon the survival and the serum urea levels of Lewis rats receiving BN renal allografts

\begin{tabular}{llll}
\hline Treatment & $\begin{array}{l}\text { Survival } \\
\text { times (days) }\end{array}$ & MST $^{\mathrm{a}}$ & $\begin{array}{l}\text { Urea } \pm \text { SD } \\
\text { (day 3) }\end{array}$ \\
\hline- & $\begin{array}{l}7.7 .8 .8 \\
8.9 .9\end{array}$ & 8 & $111 \pm 50$ \\
Salline & $\begin{array}{l}6.7 .7 .7 .7 \\
7.8 .12\end{array}$ & 7 & $127 \pm 47$ \\
Intrarenal & & & \\
\hline
\end{tabular}

MST = median survival time.

bean serwm urea levels $\pm S D(m g / 100 \mathrm{mll})$.

TABLE 2. Effect of various prednisolone treatments upon the survival of Lewis rats receiving BN renal allografts

\begin{tabular}{|c|c|c|c|c|c|c|c|}
\hline \multirow{3}{*}{$\begin{array}{l}\text { Prednisolone } \\
\text { (mg/kg/day) }\end{array}$} & \multirow{2}{*}{\multicolumn{2}{|c|}{ Daily $i_{\text {. p.injections }}$}} & \multicolumn{5}{|c|}{ Continuous infusion } \\
\hline & & & \multicolumn{2}{|c|}{ Intraperitoneal } & \multicolumn{2}{|c|}{ Intravenous } & \multirow{2}{*}{ 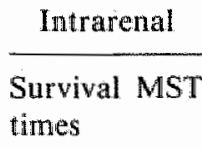 } \\
\hline & $\begin{array}{l}\text { Survival } \\
\text { times }\end{array}$ & MSTa $^{a}$ & $\begin{array}{l}\text { Survival } \\
\text { times }\end{array}$ & MST & $\begin{array}{l}\text { Survival } \\
\text { times }\end{array}$ & MST & \\
\hline \multirow[t]{2}{*}{4} & 7.7 .7 .7 .7 & 7 & 9.9 .9 .9 & 9 & 7.7 .7 .8 & 8.5 & $17.17 .18 \quad 26^{\mathrm{b}}$ \\
\hline & 8.8 .10 .11 & & 9.10 .10 .11 & & 9.15 .18 & & $\begin{array}{l}26.26>50 \\
>50\end{array}$ \\
\hline \multirow[t]{2}{*}{8} & 7.7 .7 .8 .8 & 8 & 9.9 .10 .14 & $16^{\mathrm{e}}$ & & & \\
\hline & 8.8 .32 & & $18.20 .41>50$ & & & & \\
\hline \multirow[t]{2}{*}{12} & 7.7 .7 .8 & 8 & & & & & \\
\hline & 8.10 .10 & & & & & & \\
\hline
\end{tabular}

- MST $=$ median sturviwal time (days).

b Wilcoxon rank test for difference between animals treated with continuous intrarenal infusion of prednisolone $(4 \mathrm{mg} / \mathrm{kg}$ body wt/day) and animals treated with this dose by continuous infusion i.v. $(p<0.05)$, continuous infusion i.p. $(p<0.01)$, or i.p. bolus injections $(\mathrm{p}<0.01)$.

- Wilcoxon rank test for difference between animals treated with continuous infusion i.p. $(8 \mathrm{mg} / \mathrm{kg}$ body wt/day) and animals treated with this dose by i.p. bolus injections: $(p<0.01)$.

At a dose of $4 \mathrm{mg} / \mathrm{kg}$ body wt/day intrarenal prednisolone delivery resulted in significant ( $p<0.01)$ prolongation of graft survival (MST 26 days). As depicted in Figure 2, serum urea levels of these animals remained low. The histological appearance of kidneys of these animals is, apart from some infiltration with mononuclear cells, essentially normal and no signs of graft destruction are observed (Figure $3 a$ ). In contrast, iv or ip administration of prednisolone at this closage proved to be 


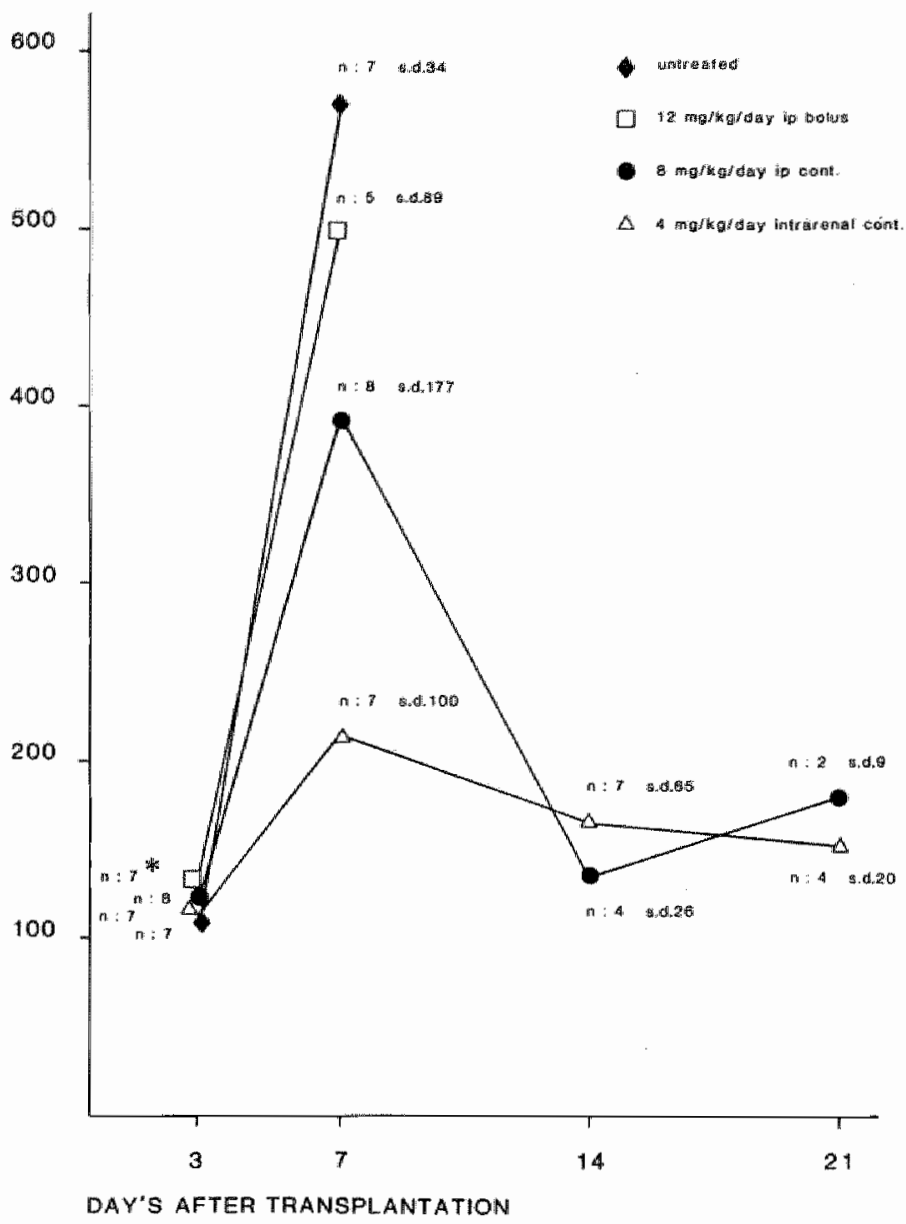

FIGURE 2. Mean serum urea levels in Lewis rats recening BN renal allografts. Lewis reciplents were untreated or received various predmisolone treatments. $S D$ and the number of animals are indicated in the figure.

* SD for all groups $<55$.

ineffective, and MST of these groups were not statistically different from controls. Kidneys of these animals showed an interstitial mononuclear cell infiltrate, together with fibrinoid deposits and obstructions of arterioles (Figure $3 \mathrm{~b}$ ).

A beneficial effect on graft survival by any route of administration other than intrarenal was only obtained if the dose of prednisolone was doubled. Continuous ip infusion of prednisolone at a dose of $8 \mathrm{mg} / \mathrm{kg}$ body wt/day resulted in a moderate improvement of graft survival (MST 16 days). Serum urea levels of these animals are depicted in Figure 2. The peak on day 7 and the large standard deviation on this day are caused by the heterogeneity of the group. Three animals died within 10 days 

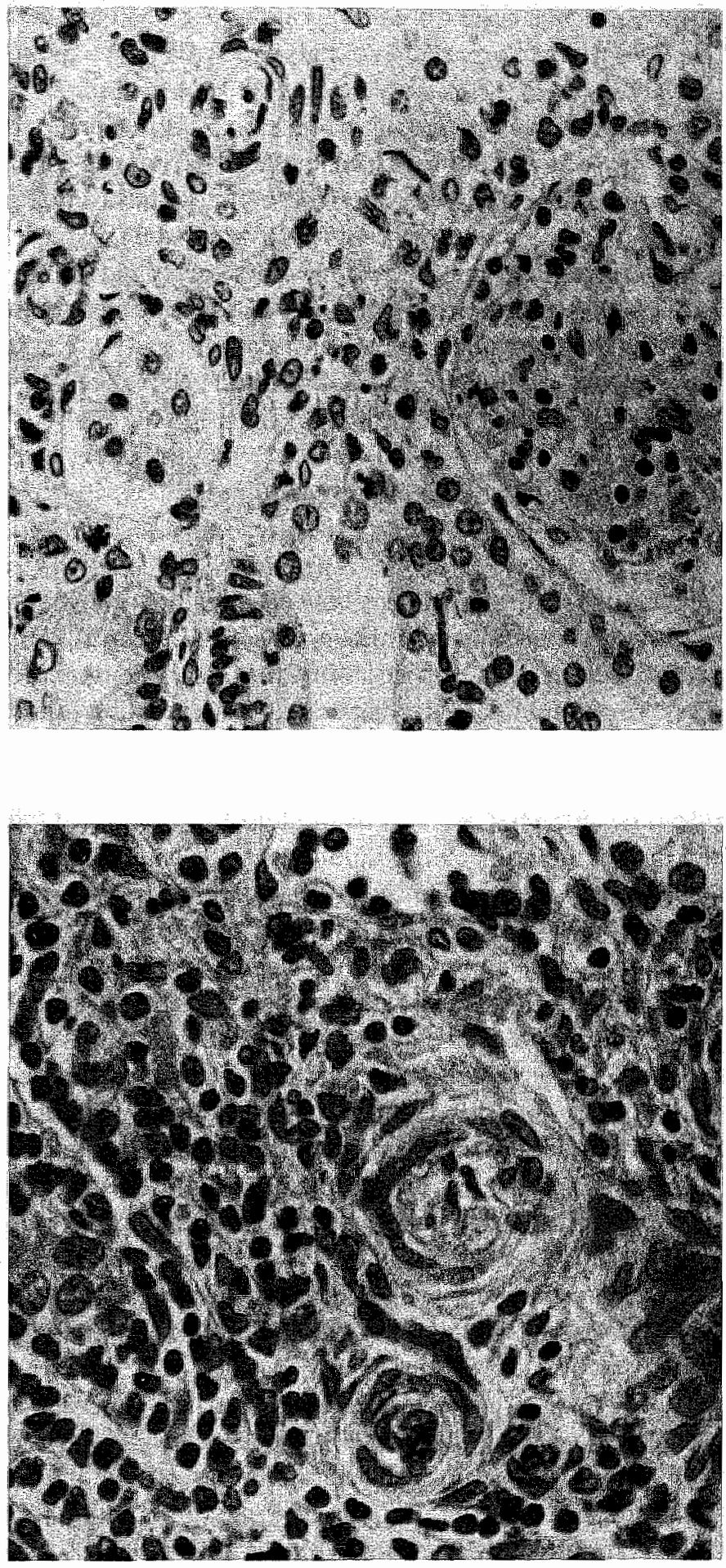

FIGURE 3a. Kraney of an animal treated with intrarenal prednisolone $4 \mathrm{mg} / \mathrm{kg}$ body wt/day. On day 8 the animal was killed while the graft was functioning well (serum urea level at day 8; $195 \mathrm{mg} / 100$ mil). Apart from some infiltration with mononuclear cells the histological picture is essentially normal (Hematoxylin and $\operatorname{eosin} 420 x$.
FIGURE $3 b$.

BN kidney grafted in Lewis recipient, killed afler 7 days of continuous ip prediniso lone infusion (4 $\mathrm{mg} / \mathrm{kg}$ body wi/day). Besides the interstitial mononuclear cell infiltrate, fibrinoid deposits and almost complete obstruction of an arteriole are clearly seen (Hematoxylin and eosin $525 x$ ). 
after transplantation and showed a mean serum urea level on day 7 of $586 \mathrm{mg} / 100$ $\mathrm{ml}$. Five animals survived for 2 weeks or more, these animals showed a mean serum urea level of $280 \mathrm{mg} / 100 \mathrm{mll}$ after one week.

Prednisolone ( $8 \mathrm{mg} / \mathrm{kg}$ body wt/day) given by ip bolus injections did not prolong allograft survival; MST was 8 days. If the dose was increased to $12 \mathrm{mg} / \mathrm{kg}$ body wt/day, ip bolus injections were still ineffective. Animals treated with $12 \mathrm{mg} / \mathrm{kg}$ body wt/day showed high serum urea levels on day 7 (Figure 2), which demonstrates that these animals died from rejection and not from other causes.

The data show that intrarenal administration of prednisolone is a successful way to achieve immunosuppression. Prednisolone administered in this way is effective at a low dosage ( $4 \mathrm{mg} / \mathrm{kg}$ body wt/day), whereas a dose more than 2 times higher is necessary if the drug is delivered by continuous ip infusion.

\section{Discussion}

In this study we describe a technique for intrarenal drug delivery to kidney allografts in rats. It was shown that the method itself has no influence on renal allograft survival. This finding is in agreement with earlier observations that the technique did not interfere with kidney function in uninephrectomized rats (1). Depending upon the pharmacokinetic properties of the drug used the technique allows selective renal allograft treatment.

We demonstrated that the immunosuppressive effect of prednisolone administered by continuous intrarenal infusion is superior to the immunosuppressive effect obtained during continuous systemic infusion. This observation proves that local prevention and treatment of graft rejection is feasible. The data suggest that inhibition of local events within the graft, such as occur during the initiation phase and during the effector phase, can result in effective immunosuppression. In our model prednisolone may interact with both stages. In mice expression of Ia antigens on macrophages and Langerhans cells can be inhibited in vivo and in vitro by prednisolone (12-13). Local administration of prednisolone may likewise suppress the induction of the immune response by reducing the expression of Ia antigens. However, a wide range of other corticosteroid actions may also explain the immunosuppressive effect during local treatment. For example it was observed that corticosteroids inhibit interleukin 1 production (12) or render interleukin 2 producing $\mathrm{T}$ cells unresponsive to interleukin 1 (14). Moreover it was reported that dexamethasone inhibits the synthesis of interleukin 2 mRNA in human peripheral blood lymphocytes in vitro (15).

In man the effector mechanisms of the immune response are relatively insensitive to corticosteroids. Inhibition of cytotoxic ' $T$ lymphocytes by corticosteroids, in vivo or in vitro, was described sporadically and was mostly achieved with extremely high concentrations or prolonged incubations $(16,17)$. Rats, in contrast to man, are corticosteroid sensitive, which, among other things, means that corticosteroid treat- 
ment results in leucocyte lysis. This property may interact with effector mechanisms during allograft rejection in rats.

Continuous infusion of prednisolone resulted in a better immunosuppressive effect than ip bolus injections. This finding is consistent with the results of Provoost (18), who demonstrated the superiority of continuous subcutaneous infusion of prednisolone over daily subcutaneous injections. These observations can be explained by the short half-life of the drug in rats, which is about $30 \mathrm{~min}(9)$. However, it was reported also that during continuous administration of prednisolone the side effects of the drug increase (19-21). A way to reduce systemic side effects is local administration, leading to a constant level of prednisolone in the target organ with low systemic levels. Intrarenal delivery of prednisolone is an example of this approach.

Our data show that the dosage of prednisolone may be reduced by at least $50 \%$ when given intrarenally, as compared with systemic administration. On the basis of theoretical considerations, the ratio between arterial blood levels during local intraarterial drug infusions (Cloc) and systemic infusions (Csys) is given by Cloc/Csys $=(1+\mathrm{Ks} / \mathrm{Qt})(22)$, where $\mathrm{Ks}$ represents systemic clearance of the drug and $\mathrm{Qt}$ is blood flow through the target tissue. In man, clearance of prednisolone is largely metabolic (23). In rats, prednisolone is also eliminated mostly by liver metabolism. Systemic clearance should be expected to be maximally equal to liver blood flow i.e. $15 \mathrm{ml} / \mathrm{min}$. Taken together with a value for renal blood flow of $\approx 15 \mathrm{ml} / \mathrm{min}$ through a single kidney in rats (1), this would result in a maximal ratio of Cloc/Csys $\approx 2$. The advantage of intrarenal drug delivery can be much greater if $\mathrm{Ks} \gg \mathrm{Qt}$, in other words, if the systemic clearance of the drug is much greater than the blood flow through the kidney. Experiments are currently in progress with this kind of high-clearance immunosuppressive drugs.

In 1969 Kountz and Cohn (24) had already shown excellent graft survival in renal transplant patients treated with intrarenal delivery of methylprednisolone over a short period. They also reported that patients treated this way did not develop systemic side effects of the drug, in contrast to patients who received systemic therapy. Our data strongly support their suggestion that local drug delivery is, in principle, an effective way to induce immunosuppression. The method of intrarenal drug delivery used by Kountz and Cohn, a catheter introduced into the renal artery via a small stabwound in the common iliac artery, has its drawbacks, however, in immunosuppressed patients. An attractive new way to achieve local drug delivery clinically is by means of prodrugs. These prodrugs are by themselves inactive, however within the organ (e.g. the kidney) they are converted into an active drug. This conversion may be an enzymatic reaction. Recently, renal prodrugs (which are activated within the kidney) were described $(25,26)$ and it would be a promising approach to immunosuppressive therapy if short-acting immunosuppressive drugs could be synthesized in this prodrug form. Our model of intrarenal drug delivery offers the possibility for selection of immunosuppressive drugs candidate for transformation into such prodrug form. 
Acknowledgments. This work was supported by the Dr. Saal van Zwanenbergstichting. We thank M. Havenith, M.D. of the Department of General Pathology, Academic Hospital Maastricht, for his advice and Mrs. K. Spronck for her secretarial assistance.

Abbreviations used in this article: BN, Brown Norway; body wt/ day, body weight per day; ip, intraperitoneal; iw, intravenous; MST, median survival time; PE, polyethylene.

\section{References}

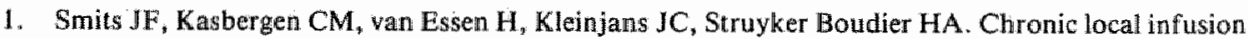
into the renal artery of unrestrained rats. Am J Physiol 1983; H: 304.

2. Lechler RI, Batchelor JR. Restoration of immunogenicity to passenger cell-depleted kidney alm lografts by the addition of donor strain dendritic cells. J Exp Med 1982; 155:31.

3. Lafferty KJ. Immunogenicity of foreign tissue. Transplantation 1980; $29: 179$.

4. Bach JF, Comment on Lafferty KJ. Immunogenicity of foreign tissue. Tramsplantation 1980; 29 : 182 .

5. Ascher NL, Chen S, Hoffman R, Simmons RL. Maturation of cytotoxic effector cells at the site of allograft rejection. Transplant Proc 1981; XIII: 1105.

6. Nemlander A, Soots A, von Willebrand E, Husberg, B, Häyry P. Redistribution of renal allograftresponding leucocytes during rejection. II Kinetics and specificity. I Exp Med 1982; 156: 1087.

7. Häyry P. Intragraft events in allograft destruction. Transplantation $1984 ; 38: 1$.

8. Ascher NL, Hoffman R, Hanto DW, Simmons RL. Cellular events within the rejecting allograft. Transplantation 1983; 35: 193.

9. Kort WJ, Weijma IM, Westbroek DL. Reductive effect of phenobarbital on graft survival in prednisolone treated rats. Eur Surg Res 1979; 11: 317.

10. Lee $S$. An improved technique of renal transplantation in the rat. Surgery 1967;61: 771 .

11. Lameyer LD, Smith J, Mowbray JF. Effect of kidney perfusion on renal allograft survival in mzathioprine treated rats. Br J Exp Path 1972; 53: 130.

12. Snijder DS, Unanue ER. Corticosteroids inhibit murine macrophage Ia expression and interleukin 1 production. J Immunol 1982; 129: 1803.

13. Nordlund $\mathrm{J} J$, Ackles $\mathrm{AE}$, Lerner $\mathbf{A B}$. The effects of ultraviolet light and certain drugs on Iabearing Langerhans cells in murine epidermis. Cell Immunol 1981; 60:50.

14. Pallacios $\mathbb{R}$, Sugawara 1. Hydrocortisone abrogates proliferation of T cells in autologous mixed lymphocyte reaction by rendering the $11-2$ producer $T$ cells unresponsive to $11-1$ and unable to syrnthesize the T cell growth factor. Scand J Immunol 1982; 15; 25.

15. Arya SK, Wong-Staal F, Gallo RC. Dexamethasone-mediated inhibition of human $T$ cell growth factor and gamma-interferon messenger RNA. J Immunol 1984; $133: 273$.

16. Rosenberg JC, Lysz K. Suppression of human cytotoxic llymphocytes by methylprednisolone. Transplantation 1978; 25: 115.

17. Balow JE, Hunninghake GW, Fauci AS. Corticosteroids in human lymphocyte mediated cytotoxic reactions. Transplantation $1977 ; 23: 322$.

18. Provoost AP, de Keyzer MH, Kort W W, Wolff ED. Superiority of continuous infusion of prednisoIone over daily injections in the prolongation of heart allograft survival in rats. Transplantation 1982; 34: 221 .

19. Reed WP, Lucas ZJ, Cohn R. Alternate-day prednisone therapy after renall transplantation. Lancet $1970 ; 1: 747$. 
20. Sheagren JN, Jowsey J, Bird DC, Gurton ME, Jacobs JB. Effect on bone growth of daily versus alternate day corticosteroid administration: an experimental study. $\$$ Lab Clin Med 1977; 89: 120.

21. McEnery PT, Gonzalez LL, Martin ILW, West CD. Growth and development of children with renal transplants: Use of alternate-day steroid therapy. J Pediatr 1973; 83: 806.

22. Smits JF, Thijssen HH. Spatial control of drug action: Theoretical considerations on the pharmacokinetics of target-aimed drug deliwery. In: Rate controlled drug administration and action (ed.; HAJ Struyker-Boudier), CRC Press, Boca Ration, USA. 1986.

23. Gambertoglio JG, Amend WJ, Benet $L Z$. Pharmacokinetics and bioavailability of predrisone and prednisolone in healthy wolunteers and patients: a review. J Pharmacokinet Biopharm 1980; 8: 1 .

24. Kountz SL, Colyn R. Initial treatment of renal allografts with large intrarenal doses of immunosuppressive drugs. Lancet $1969 ; 1: 338$.

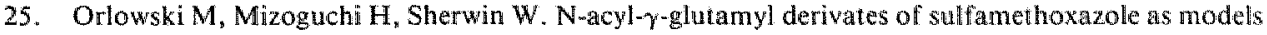
of kidney selective prodrugs. I Pharmacol Exp Ther 1980; $212: 167$.

26. Smits JF, Struyker-Boudier HAJ. Preferential renal vasodilator effects of CGP 22979A in conscious sponianeously hypertensive rats. J. Pharmacol Exp Ther 1985; 232: 845. 


\section{Study 5}

\section{Immunohistological observations in rat kidney allografts following local steroid administration}

Published in The Journal of Experimental Medicine 1987; 166: 1205.

\section{Summary}

In this report we investigated local regulatory mechanisms in graft rejection and their response to local immunosuppressive therapy. For this purpose local immunosuppression was induced in rat kidney allografts by intrarenal infusion of prednisolone. Intrarenal drug delivery resulted in high drug levels within the graft and low systemic drug levels. Systemic drug levels were by themselves not sufficiently immunosuppressive to induce graft survival, and local prednisolone levels within the graft proved to be responsible for prolongation of graft survival. During intrarenal drug delivery, systemic responsiveness to the renal allograft proved normal, since intrarenally treated grafts were infiltrated by MHC-class II positive host cells and, except for a somewhat lower percentage of macrophages, cellular infiltration in intrarenally treated grafts was comparable to untreated grafts. However, T cells and macrophages present in intrarenally treated grafts were not able to destroy the grafted tissue. Local immunosuppressive therapy resulted in inhibition of IL2 receptor expression, absence of IFN- $\gamma$, and prevention of MHC-class 11 induction on grafted tissue. These observations strongly indicate the presence of local regulatory mechanisms in graft rejection. The experimental model described can be used for further analysis of these intragraft events. Moreover, the results demonstrate that local immunosuppressive therapy can contribute to effective inhibition of cellular immune response in graft rejection. 


\section{Introduction}

Several immunosuppressive regimens have been used to inhibit the immune response in autoimmune disease and allograft rejection. In general the inhibition interferes mainly with the two pathways involved in cellular immune response: specific cellmediated cytotoxicity and delayed-type hypersensitivity (DTH) (1-8). In both mechanisms, lymphokine production by $T$ cells plays a crucial role; lymphokines are essential for the proliferation and differentiation of cytotoxic $T$ cell precursors, as well as for the effector phase of DTH reactions. Lymphokines, such as interferons, are also potent inducers of MHC-class I and MHC-class II antigens (9-11), which both play a critical role in the development and augmentation of the immune response (12-16). The inhibition of lymphokine production e.g. interferon- $\gamma($ IFN- $\gamma$ ) and interleukin-2 (IL2) and the modulation of MHC antigen expression was shown to be an important mode of action of immunosuppressive drugs such as steroids $(17,18)$ and cyclosporin $A(19,20)$.

So far, treatment of autoimmune disease and allograft rejection is achieved by systemic immunosuppression without specificity for the organs affected. Recently however, controversy has increased concerning the role of systemic versus local regulatory mechanisms in cellular immune response. Immune stimulation by $\mathrm{MHC}$ antigen expression has been seen both as a local and systemic process in autoimmune disease, as well as in allograft rejection (21-26). The same controversy holds true for the effector mechanisms during cellular immune response. Originally it was proposed that sensitized cells mature within the central lymphoid tissue and subsequently migrate as mature effector cells to the target tissue and mediate tissue destruction $(8,27-29)$. More recently, however, it was demonstrated that cytotoxic $T$ lymphocytes (CTL) could mature within sponge matrix allografts, which implies an essential role for local development of CTL within the target organ, and hence local production of lymphokines (30-32). In accordance with these observations, we recently demonstrated that intrarenal prednisolone delivery to rat renal allografts was superior to systemic administration of the drug (33). These data provide suggestive evidence for local regulation of the immune response during allograft rejection and autoimmune disease. Moreover, they indicate that the local immune response within the affected organ is a favourable subject for local immunosuppressive therapy. In this study we further analyze local regulatory mechanisms in graft rejection and their response to local immunosuppressive therapy.

\section{Materials and methods}

Animals. Inbred Brown Norway ( $\left.\mathrm{RT}^{\mathrm{N}}\right)$ and Lewis ( $\left.\mathrm{RT}^{\mathrm{L}}\right)$ male rats between 2 to 4 months of age were obtained from the Department of Experimental Animal Services of the University of Limburg. 
Experimental model. Right kidneys were transplanted from Brown Norway (BN) to Lewis rats using microsurgical techniques according to the method of Lee (34) with modifications of Lameyer for urether bladder anastomosis. Ischemia times were approximately 30 minutes. Recipient kidneys were both removed immediately after transplantation and graft survival was assessed by animal survival. Recipient treatment consisted of prednisolone (Centrachemie, Etten-Leur, The Netherlands) administered by means of continuous infusion either intrarenally or intraperitoneally (ip). Continuous intrarenal drug delivery was performed as described (33). Briefly, immediately after transplantation a catheter was introduced into the suprarenall artery of the transplanted kidney. Because the suprarenal artery in rat directly empties into the main renal artery, this method allows selective drug administration to the graft without affecting renal blood flow. After potency of the infusion system was checked the catheter was connected to an osmotic minipump (model 2ML2, Alza, Palo Alto, CA) filled with the drug. Pumps were implanted into the abdominal cavity and delivered prednisolone continuously from day 0 till day 13 after transplantation. The technique used for intrarenal drug delivery showed by itself no significant effect on renal allograft survival. Median graft survival time (MST) in animals treated with intrarenal infusion of saline was 7 days $(1 \times 6,5 \times 7,1 \times 8,1 \times 12$ days), which was not significantly different from untreated controls, MST 8 days ( $2 \times 7,3 \times 8,2 \times 9$ days). For continuous intraperitoneal infusion, pumps administered prednisolone directly into the abdominal cavity. Prednisolone was dissolved in pyrogen-free distilled water without heparin. The dose of the drug $(4 \mathrm{mg} / \mathrm{kg} / \mathrm{body}$ weight per day) was adjusted to body weight of the recipient at the day before allografting was performed (day -1 ). In animals that received intrarenal treatment, correct position of the catheter was checked at autopsy.

Determination of prednisolone levels. Recipients were treated with prednisolone 4 $\mathrm{mg} / \mathrm{kg}$ body weight per day given either by continuous intrarenal infusion or continuous intraperitoneal infusion. On day 3 after transplantation, blood was drawn and allografts were excised for analysis of prednisolone levels. Prednisolone was analyzed with HPLC. The method, as published by Rose and Jusko (35), was used with the following modifications. Separation was performed on a $250 \times 4.6 \mathrm{~mm}$ Lichrosorb 10-DIOL ${ }^{\mathbb{R}}$ column (Merck, Darmstadt, FRG). Eluent composition was: methylene dichloride $73 \%$; hexane $25.5 \%$; methanol $1.5 \%(\mathrm{v} / \mathrm{v})$. The coefficient of variation for prednisolone was approximately $5 \%$, the lower limit of detection was about $10 \mathrm{ng} / \mathrm{ml}$ in serum.

Immunohistologic studies. Renal allografts were excised on days 3,7 , and 12 after transplantation. Immediately after harvesting, tissue samples were embedded in Tissue TEK II (Miles Scientific, Naperville, IL) mounting medium and snap-frozen in isopentane $\left(-70^{\circ} \mathrm{C}\right)$. Cryostat sections of $5 \mu \mathrm{m}$ were cut, air dried, fixed in acetone, and stored at $-20^{\circ} \mathrm{C}$ until used. Immunohistological studies were performed using indirect immunoperoxidase staining. Briefly, slides were thawed at room tempera- 
ture for 15 minutes, washed for 5 minutes in phosphate buffered saline (PBS), and then incubated with the appropriate mouse monoclonal antibody for 30 minutes at room temperature. Slides were washed again in PBS and subsequently incubated for 30 minutes with horseradish peroxidase-coupled rabbit anti-mouse immunoglobulin (Dako, Copenhagen, Denmark) diluted 1:100 in 10\% rat serum. After washing in PBS, sections were developed with a solution of $0.5 \mathrm{mg} / \mathrm{ml}$ diaminobenzidine tetrahydrochloride (Serva, Heidelberg, FRG) and $0.01 \% \mathrm{H}_{2} \mathrm{O}_{2}$ in $0.05 \mathrm{M}$ Tris buffer, pH 7.6. After 10 minutes slides were washed in tap water and counterstained with hematoxylin. For parallel histologic observations, grafted tissue was fixed in neutral-buffered formalin, processed in a routine manner, and hematoxylin and eosin-stained sections were examined.

Monoclonal antibodies. The following mouse anti-rat monoclonal antibodies were used; MRC OX6 (36) (Seralab, Crawley Down, United Kingdom) directed against rat MHC-class II antigens. This antibody reacts with inbred rat strains of the haplotypes $\mathrm{L}$ and $\mathrm{N}$; His 19 (37) reacts with rat MHC-class II antigens of the rat strains of haplotype $\mathrm{L}$ but not with antigens of rat strains of the $\mathrm{N}$ haplotype. The antibody was kindly provided by Dr. Stet (Dept. of Histology, University of Groningen, The Netherlands); MRC OX19 (38) (Seralab, Crawley Down, United Kingdom) reacts with all rat $T$ lymphocytes; W3/25 $(39,40)$ mainly recognizes $T$ helper cells but also stains a subpopulation of macrophages; OX8 $(39,41)$ reacts with T cytotoxic/suppressor cells and a subpopulation of NK cellls. ED2 (42) recognizes rat macrophages; the antibody is directed against membrane antigens of tissue macrophages, and has been described in detail by Dijkstra (Dept. of Histology, Free University, Amsterdam, The Netherlands), who kindly provided the antibody. ART18 (43) is directed against an antigenic determinant of the IL2 receptor molecule in rat. The antibody was kindly provided by Dr. Diamantstein (Dept. of Immunology, Klinikum Steglitz, Berlin, FRG). DB1 (44), reacting against rat IFN- $\gamma$, was kindly provided by Dr. Van der Meide (Primate Centre, TNO Rijswijk, The Netherlands). The antibody was prepared by fusing spleen cells from $\mathrm{BALB} / \mathrm{C}$ mice immunized with recombinant rat IFN- $\gamma$ with the myeloma $\mathrm{SP}_{2} \mathrm{O}$. The antibody was found to bind to rat IFN- $\gamma$ in an ELISA and to block IFN- $\gamma$ activity in a virus-protection assay. All monoclonal antibodies were used at saturating dilutions of partially purified immune ascites. Normal kidney tissue from $B N$ and Lewis strain stained negative with the monoclonal antibodies ART18 (anti-IL2 receptor) and DB1 (anti-IFN- $\gamma$ ). Normal kidney tissue was almost devoid of ED2 positive cells (macrophages).

Morphometric analysis of tissue sections. When indicated the cellular infiltration within the grafts was quantified by morphometric analysis according to the method of McWhinnie (45). Cellular infiltration within a section was assessed by point counting using a square grid in the eyepiece of the microscope. The percentage area of each section occupied by cells of a particular antigenic specificity was calculated as follows: 
$\begin{aligned} & \text { Percentage area } \\ & \text { infiltrated }\end{aligned}=\frac{\text { number of positive cells under grid intersections }}{\text { total number of grid intersections }} \times 100 \%$

The accuracy of the technique is proportional to the number of points counted. To maintain a standard error of less than $10 \%, 4250$ points were counted when density of the infiltrate was less than $10 \%, 600$ points were counted when density of the infiltrate was more than $10 \%$. For point counting a 120 point or 850 point graticule was used, within each section 5 fields were chosen at random and counted by a magnification of $x 400$.

\section{Results}

Experimental model for local immunosuppression. Allografts treated locally with prednisolone $4 \mathrm{mg} / \mathrm{kg}$ body weight per day showed significant prolongation of graft survival (MST, 28 days). As demonstrated in Table I, local drug delivery resulted in a mean kidney prednisolone level of $213 \mathrm{ng} /$ kidney and a mean plasma level of the drug of $53 \mathrm{ng} / \mathrm{ml}$. To ascertain that, during intrarenal infusion, local immunosuppression within the graft was responsible for the immunosuppressive effect observed, recipients were treated ip with the same dose of prednisolone. Systemic administration of the drug resulted in a MST of 9 days, which was not significantly different from control animals. During ip drug delivery the mean plasma prednisolone level was $46 \mathrm{ng} / \mathrm{ml}$. The mean kidney prednisolone level was $126 \mathrm{ng} / \mathrm{kidney}$. These data demonstrate that the systemic plasma level reached during local drug delivery is by itself not sufficiently immunosuppressive to induce graft survival. From these observations it can be concluded that during intrarenal treatment, high kidney prednisolone levels and hence local immunosuppression mainly are responsible for the immunosuppressive effect observed. Moreover, the model of intrarenal drug delivery offers the possibility to further analyze local regulatory mechanisms in graft rejection and their response to local immunosuppressive therapy.

The effect of local immunosuppressive therapy on cellular infiltration. Animals, untreated or treated with prednisolone either intrarenally or intraperitoneally, were sacrificed at days 3,7 , and 12 after transplantation, and immunohistologic studies were performed.

Untreated animals showed perivascular and interstitial mononuclear cell infiltrates at day 3 after transplantation (Table II). Most of the infiltrating cells were positive for His 19, recognizing MHC-class II antigens of host type. By day 7 after transplantation, cellular infiltration was clearly increased and intense infiltration of $\mathrm{MHC}$ class II positive cells throughout the kidney was observed associated with marked destruction of renal tissue (Figure 1a).

In animals treated with prednisolone ip (MST, 9 days), cellular infiltration was somewhat postponed compared with untreated animals. Eventually, however, at 
TABLE I. Graft survival and mean prednisolone levels in plasma and renal allografts during continuous delivery of prednisolone intrarenally or intraperitoneally.

\begin{tabular}{|c|c|c|c|c|}
\hline \multirow[t]{2}{*}{ Therapy } & \multicolumn{2}{|c|}{$\begin{array}{c}\text { Mean ( } \pm \text { SD) prednisolone } \\
\text { level on day } 3\end{array}$} & \multirow[t]{2}{*}{ MST } & \multirow[t]{2}{*}{ in } \\
\hline & Plasma & Renal allograft & & \\
\hline & $\mathrm{ng} / \mathrm{ml}$ & ng/kidney & days & \\
\hline $4 \mathrm{mg} / \mathrm{kg}$ Continuously intraperitoneally & $46 \pm 8$ & $126 \pm 21$ & 9 & 9 \\
\hline $4 \mathrm{mg} / \mathrm{kg}$ Continuously intrarenally & $53 \pm 14^{*}$ & $213 \pm 80^{5}$ & $28 *$ & 9 \\
\hline
\end{tabular}

* MST = median graft survival time as determined in graft survival studies. MST in untreated controls is 8 days.

+ Wilcoxon rank test for difference berween plasma prednisolone levels in animals treated ip and intrarenally is not significant.

$\$$ Willoxon rank test for difference between prednisolone levels in renal allografts of animals treated ip and intrarenally $(p<0.05)$.

* Wilcoxon rank test for difference between MST in animals treated ip and intrarenally with prednisolone $(p<0.01)$.

day 7 after transplantation, dense infiltration of MHC-class II positive cells was observed accompanied by marked destruction of grafted tissue.

The histologic picture of animals treated intrarenally was completely different from untreated and ip treated rats (Table II). Intrarenally treated grafts also showed distinct cellular infiltration with MHC-class II positive cells (Figure 1b), however, extensive tissue damage and necrosis was not observed.

For further analysis, the composition of cellular infiltrates in untreated and treated animals was investigated (Table III). At day 7 after transplantation, untreated grafts showed cellular infiltrates composed of $T$ cells and macrophages (Figures $\mathbb{1 c}, \mathrm{d})$. $T$ cells were of $\mathrm{T}$ helper as well as $\mathrm{T}$ cytotoxic/suppressor phenotype; staining with the monoclonal antibodies $\mathrm{W} 3 / 25$ and $\mathrm{OX} 8$ resulted respectively in a mean area of infiltration of $28 \%$ and $29 \%$, which is a ratio of about 1 . Similar levels and patterns of infiltration were found in ip treated animals. Grafts treated intrarenally also showed cellular infiltrates composed of $T$ cells and macrophages, however, with a lower percentage of macrophages as compared with untreated animals (Table III, Figures $1 \mathrm{e}, \mathrm{f})$. Staining with the monoclonal antibodies $\mathrm{W} 3 / 25$ and $\mathrm{OX} 8$ resulted in a mean area of infiltration of $23 \%$ and $26 \%$, which is comparable to untreated animals and also results in a ratio of about 1 . Thus except for less infiltration with macrophages, cellular infiltration in intrarenally treated animals was comparable to untreated or ip treated rats.

Effect of local immunosuppressive therapy on IL2 receptor expression, IFN- $\gamma$ production and MHC-class II antigen induction on renal tissue. To further analyze the positive effects of local immunosuppression on renal allograft rejection, 
TABLE II. Immunohistological observations in rat renal allografts after various treatments.

\begin{tabular}{|c|c|c|c|c|c|}
\hline Therapy & $\begin{array}{l}\text { Area infil- } \\
\text { trated by } \\
\text { MHC class } \\
\text { II-positive } \\
\text { host cells } \\
\left.\text { (His } 19^{+}\right)^{*}\end{array}$ & $\begin{array}{l}\text { UL-2 } \\
\text { receptor } \\
\text { on } \\
\text { infiltrating } \\
\text { cells } \\
\text { (ART18+) }\end{array}$ & $\begin{array}{l}\text { Presence of } \\
\text { FN= } \gamma \\
\left(\mathrm{DB1}{ }^{+}\right)\end{array}$ & $\begin{array}{l}\text { MHC class } \\
11 \text { expres } \\
\text { sion on } \\
\text { fubules } \\
\left(0 \times 6^{+}\right)\end{array}$ & $\begin{array}{l}\text { Graft destruc } \\
\text { tion, edema, } \\
\text { themorrhage } \\
\text { necrosis** }\end{array}$ \\
\hline \multicolumn{6}{|l|}{$\mathrm{BN}-\mathrm{BN}$} \\
\hline Day 7*** & $6 \# 1$ & - & - & - & - \\
\hline \multicolumn{6}{|c|}{$\mathrm{BN} \rightarrow$ Lewis } \\
\hline Day 3 & $15 \pm 4$ & $+1-$ & $+1-$ & + & - \\
\hline Day 7 & $30 \pm 7$ & + & + & $+4+$ & +++ \\
\hline \multicolumn{6}{|c|}{$\mathrm{BN}$ - Lewis } \\
\hline $\begin{array}{l}4 \mathrm{mg} / \mathrm{kg} \\
\text { Day } 3\end{array}$ & $6 \pm 1$ & - & - & - & - \\
\hline Day 7 & $33 \pm 7$ & + & + & $+*$ & $++1+4+$ \\
\hline \multicolumn{5}{|c|}{ BN - Lewis } & \\
\hline Day 3 & $5 \pm 1$ & - & - & - & - \\
\hline Day 7 & $27 \pm 6$ & $+1-$ & $+1-$ & + & - \\
\hline Day 12 & $20 \pm 5$ & - & - & - & - \\
\hline
\end{tabular}

Data represent consistent observations made in all rais of the experimental group $(n=4$ or 5 ).

* In the BN - Lewis strain combination, MHC-class II antigens on host cells were identified with the monoclonat antibody His 19 , which reacts with the MHC-class II antigens of rat strains of the haplotype $L$, but not with MHC-class $I /$ antigens of the rat strains of the haplotype $N$. In the BN - BN sirair combination, MHC-class $I$ antigens on infilirating cells were identified with $O X 6$, which recognizes rat MHC-class $I I$ antigens of the rat strains of haplotype $L$ and $N$. Results are expressed as the percentage area of the tissue section infiltrated by MHC-class II positive cells. Data given are mean values $\pm S D$.

* Examined on routine $H$ and $E$ stainings.

** Day after grafing.

grafts were stained for IL2 receptor expression, the presence of IFN- $\gamma$, and the ex pression of MHC-class II antigens on renal tissue (Table II). In untreated animals weak staining with ART18 and DB1 could be seen on cells in areas with cellular infiltration by the third day after transplantation. Serial sections stained with OX19 indicated that the cells positive for DB1 were $T$ lymphocytes, as were the vast majority of the cells positive for ART18 (data not shown). On day 7 after transplantation the amount of positive cells was significantly increased (Figures $2 \mathrm{a}, \mathrm{b}$ ). At that time, positive cells were scattered throughout the kidney and were present as isolated cells in the interstitium as well as in cellular infiltrates. The time course of the induction of MHC-class II antigens on renal tissue was in accordance with the stainings for IFN- $\gamma$. On day 3, several foci of MHC-class I] expression on renal tubulles were demonstrated. By the $7 \mathrm{th}$ day after transplantation, MHC-class II expression was 

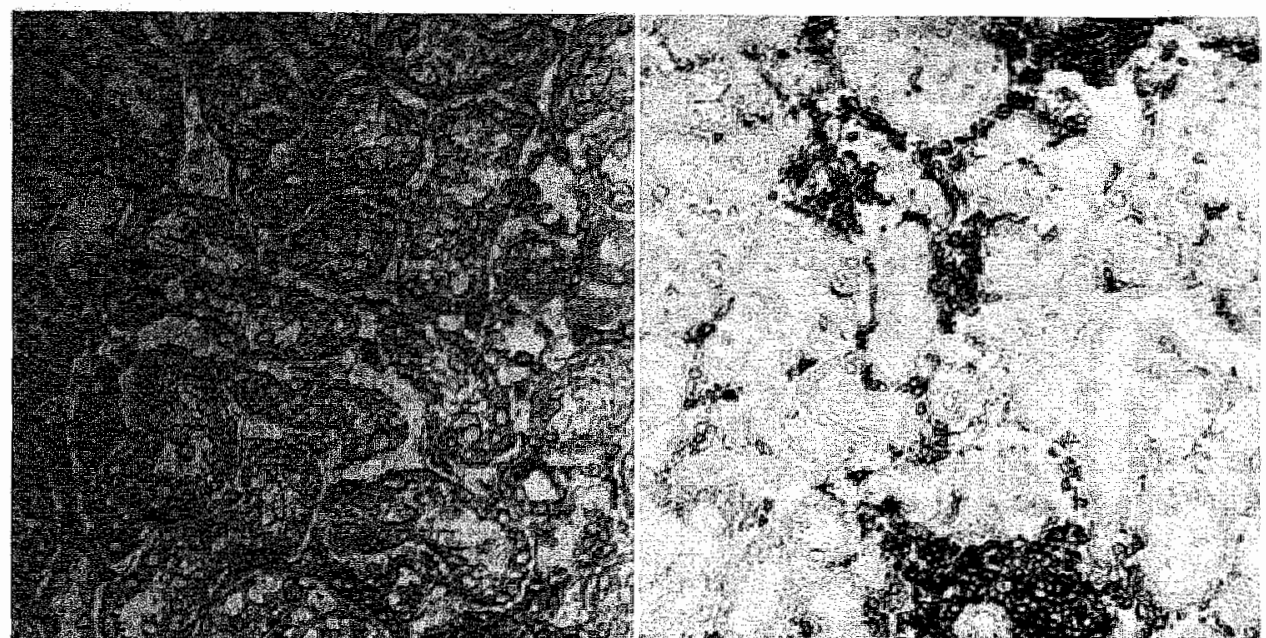

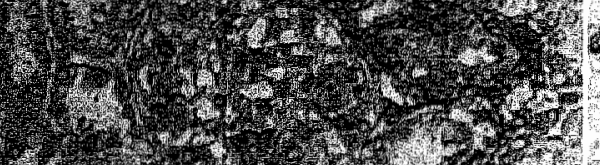

(2)

F H.

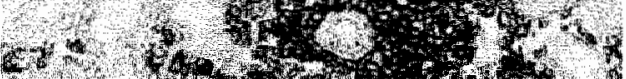

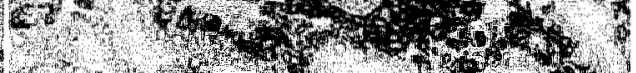
H. H.

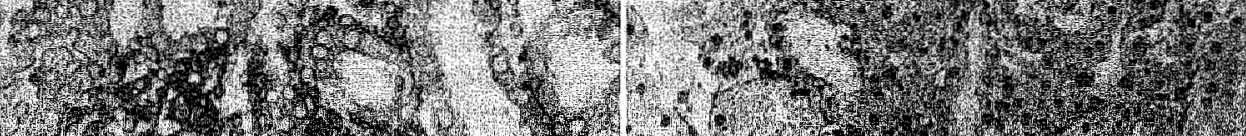
1.7. Thx

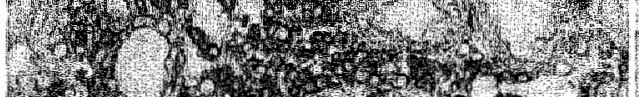

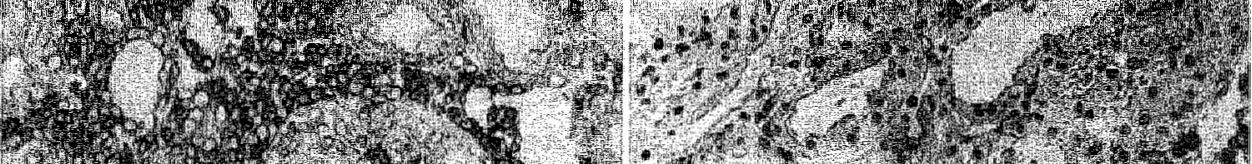

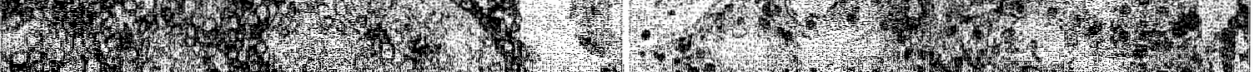
H.7.7.

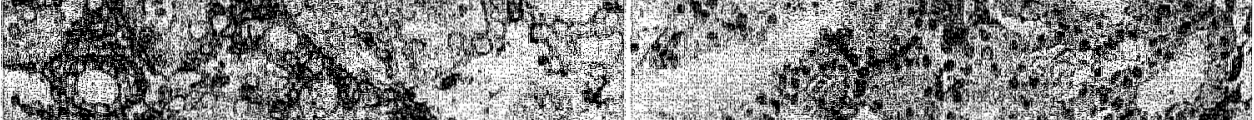

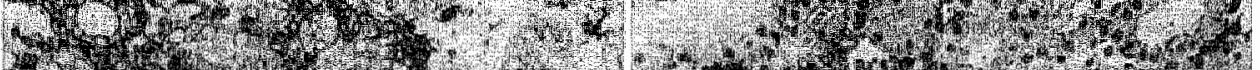
7.7. 7.7.6.

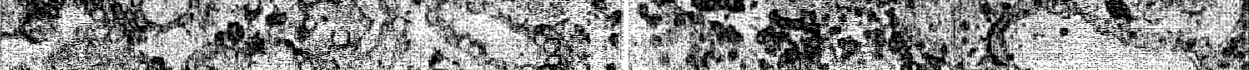
4.

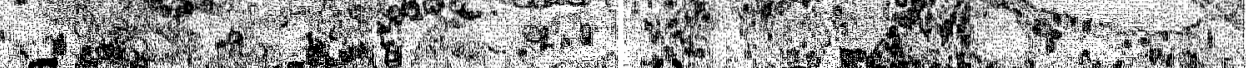

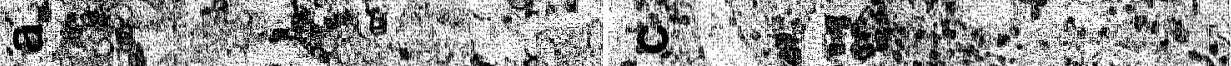

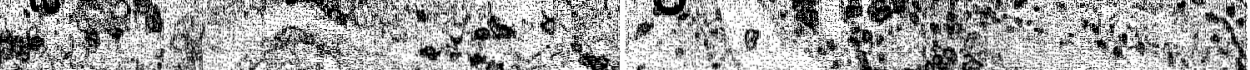

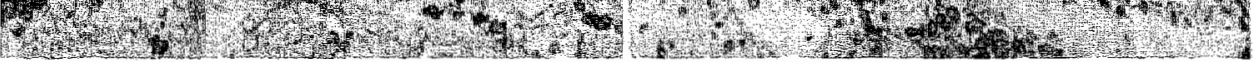




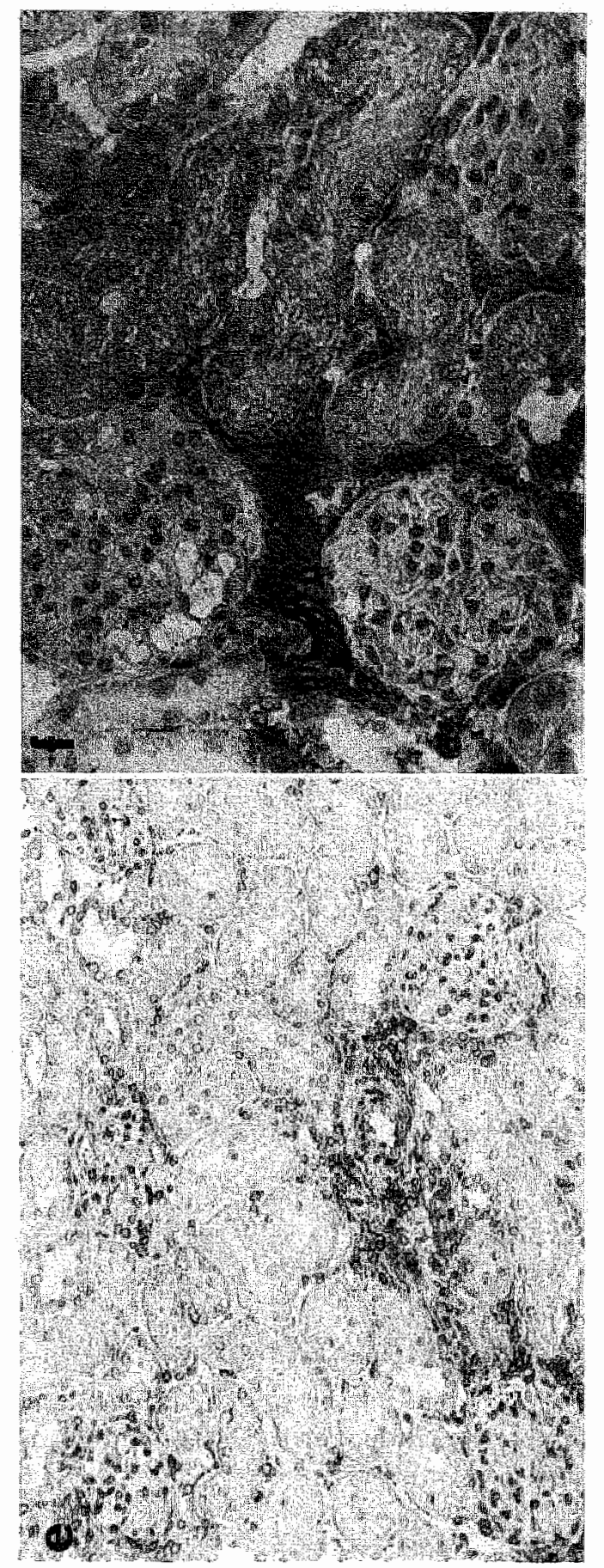

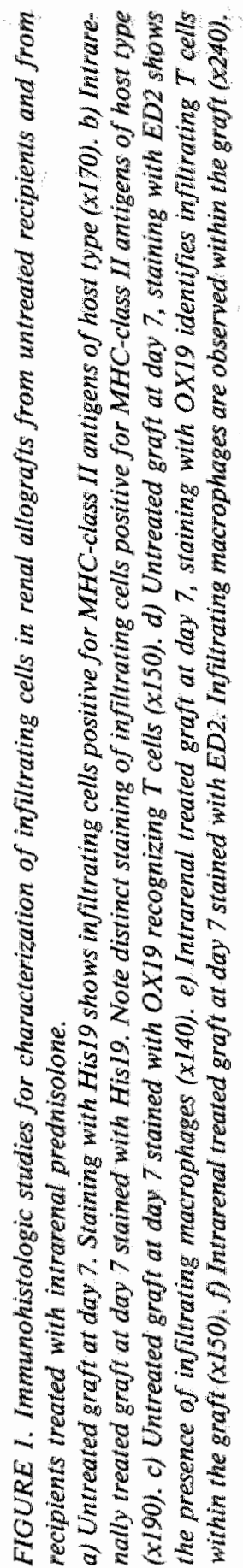


TABLE III. Phenotypic composition of the cellular infiltrate in rat renal allografts after various treatments*

Therapy

Percentage area infiltrated by positive cells**

\begin{tabular}{llllll}
\cline { 2 - 5 } & $\begin{array}{l}\text { OX19 } \\
\text { T cells }\end{array}$ & $\begin{array}{l}\text { W3/25 } \\
\text { Th }\end{array}$ & $\begin{array}{l}\text { OX8 } \\
\text { Tc/s }\end{array}$ & $\begin{array}{l}\text { W3/25 } \\
\text { OX8*** } \\
\text { Th,Tc/s }\end{array}$ & $\begin{array}{l}\text { ED2 } \\
\text { macrom } \\
\text { phages }\end{array}$ \\
\hline $\begin{array}{c}\text { BN } \rightarrow \text { Lewis } \\
\text { untreated }\end{array}$ & $24 \pm 6$ & $28 \pm 5$ & $29 \pm 7$ & $37 \pm 6$ & $38 \pm 11$ \\
$\begin{array}{c}\text { BN }- \text { Lewis } \\
4 \text { mg/kg i.p. }\end{array}$ & $21 \pm 5$ & $25 \pm 6$ & $27 \pm 7$ & $37 \pm 9$ & $31 \pm 8$ \\
$\begin{array}{c}\text { BN }- \text { Lewis } \\
4 \text { mg/kg } \\
\text { intrarenally }\end{array}$ & $20 \pm 4$ & $23 \pm 4$ & $26 \pm 6$ & $32 \pm 8$ & $18 \pm 6$ \\
\hline
\end{tabular}

* Immunohistological studies were performed on grafts removed on day 7 after transplantation.

* Data given are mean values $\pm S D$. Per group $n=5$.

*** Stained simultaneously with $W 3 / 25$ and $O X 8$.

markedly increased, and distinct staining of MHC-class II antigens on renal tissue was observed (Figure 2c).

Grafts from animals treated ip with prednisolone showed immunohistological stainings on day 7 comparable to untreated rats.

Completely different results however were obtained in animals treated intrarenally (Table II). Grafts from these rats showed almost no staining for IL2 receptor expression and IFN- $\gamma$, despite the presence of cellular infiltrates (Figures $3 a, b, c)$. Except for some weak staining on day 7, all stainings with ART18 and DB1 were negative on day 3 as well as on day 12 after transplantation. These findings correspond well to the observations made in stainings with OX6. On day 3 and day 12 after transplantation all kidneys examined failed to show an increase in MHC-class II antigen expression on renal tissue as compared with stainings of normal nongrafted kidneys (Figure 3d). Only on day 7 after transplantation were several small foci of MHCclass II antigen expression on renal tissue observed. However, compared with ip treated or untreated grafts this staining was very weak. From the observations, as summarized in Table II, we conclude that intrarenal prednisolone levels interfere with the expression of IL2 receptor, the production of IFN- $\gamma$, and the induction of MHC-class II antigen expression on renal tissue. 


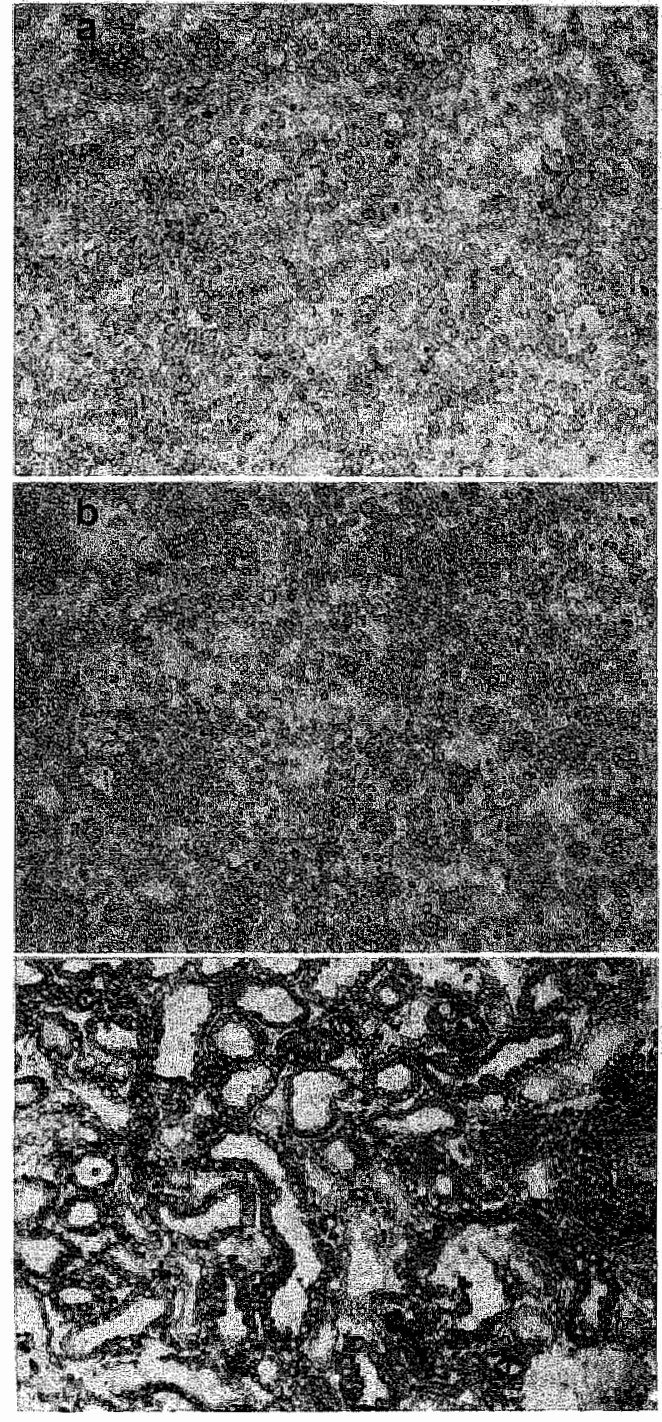

FIGURE 2. Cryostat sections of untreated grafts removed on day 7 after iransplantation. Sections were stained with the monoclonal antibodies a) $A R T I 8$, b) $D B I$ and c) $0 \times 6$.

Infiltrating cells positive for IL a receptor (a) and IFN- $\gamma$ (b) are scattered throughout the graft (x100). Staining with $0 \times 6(\mathrm{c})$ shows strong induction of MHC-class II antigens on renal mbwes cells associated with marked destruction of renal tissue (xI00). 


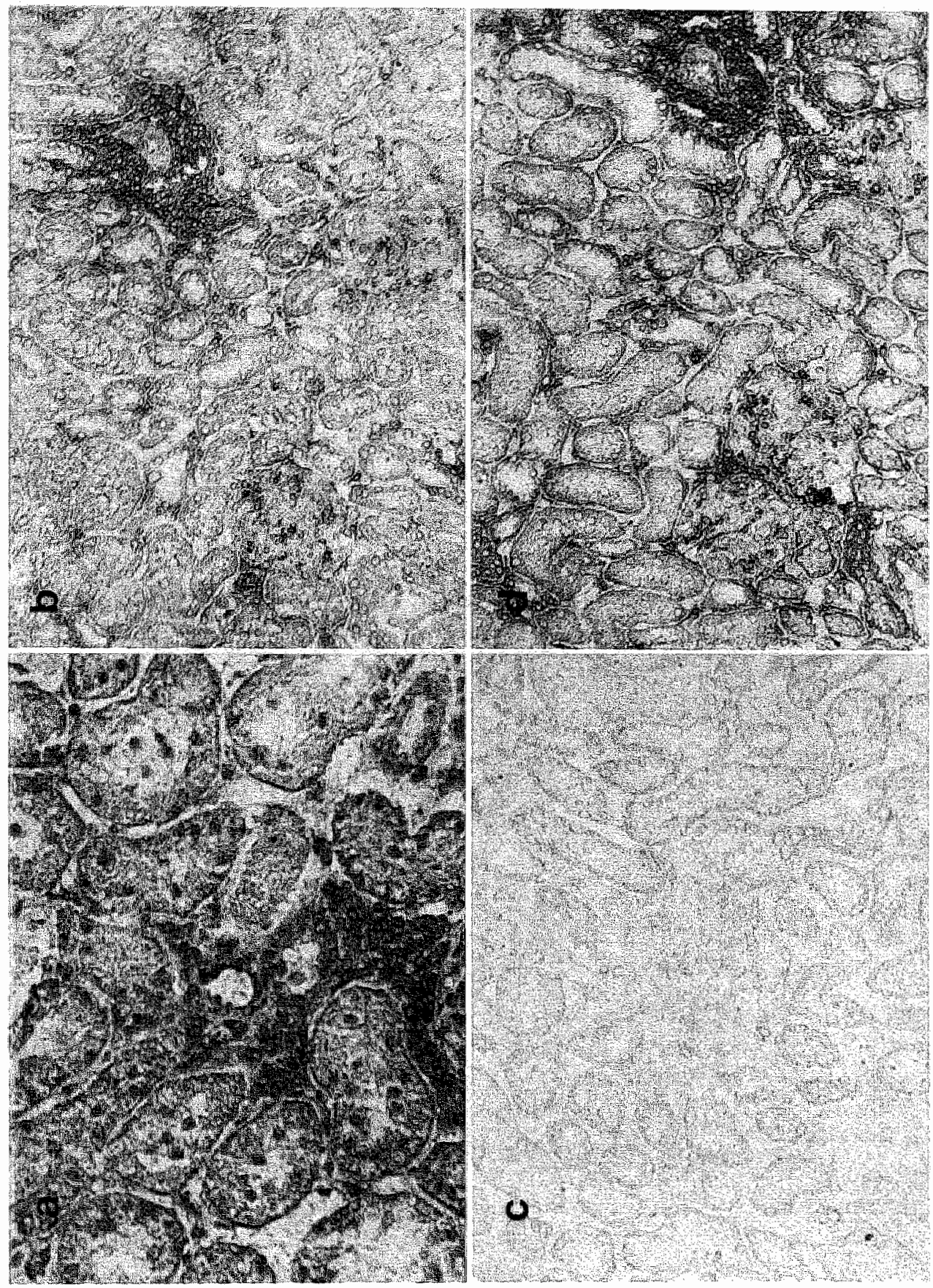

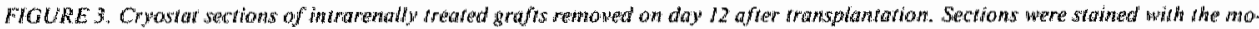

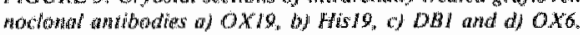

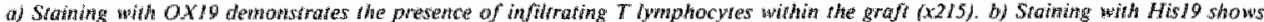

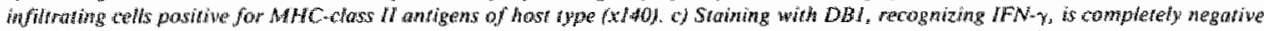

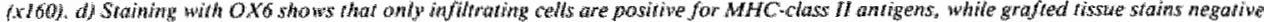
(x) $10 \mathrm{j}$. 


\section{Discussion}

In this study we demonstrate that intrarenal prednisolone delivery to rat renal allografts results in high drug levels within the graft combined with low systemic drug levels. Systemic drug levels were, by themselves, not immunosuppressive, and local prednisolone levels within the graft proved to be responsible for the immunosuppressive effect obtained. This experimental model was used to analyze local events in allograft rejection and their response to immunosuppressive therapy.

The role of local versus systemic immune processes in cellular immune response has been studied in allograft models $(30,32,46)$. These studies report extensive white cell traffic between the lymphoid tissue and the graft in the early days after transplantation. After a time, however, the rejection process becomes independent of the host, and lymphocytes mature and proliferate within the graft, which implies an essential role for local regulatory mechanisms and hence local production of lymphokines. According to these data, we observed that local treatment of allografts does not prevent the accumulation of activated white cells within the graft, as occurs in the early days after transplantation. White cells positive for MHC-class II antigens of host type were equally present in untreated and intrarenally treated rats. Moreover, the composition of the cellular infiltrate in intrarenally treated grafts was comparable to the untreated grafts, except for a lower percentage of infiltrating macrophages. The ratio of W $3 / 25$ - OX8 positive cells, which is variably reported to be changed during successful systemic immunosuppressive therapy $(4,45,47,48)$, was not affected by local treatment. These data show that during local treatment the systemic responsiveness of the host is normal. Moreover, the findings confirm that the model of local prednisolone delivery allows the analysis of intragraft events and their response to local immunosuppressive therapy.

Local treatment was associated with lack of IL2 receptor expression, absence of IFN- $\gamma$, and inhibition of MHC-class II induction on renal tissue. Inhibition of these intragraft events most likely prevented $\mathrm{T}$ cells and macrophages present within the graft from destroying the grafted tissue.

Downregulation of MHC-class II expression on grafted tissue is postulated to be an essential mechanism during successful systemic immunosuppressive therapy (49). In this study the induction of $\mathrm{MHC}$-class II expression on renal tissue was inhibited by local treatment, which strongly suggests local regulation of MHC-class II expression within the graft. Local regulation of MHC-class II expression in cellular immune response was also postulated by others $(50,51)$. For example, Nathan et al. showed that intradermal injection of IFN- $\gamma$ induced local effects similar to DTHlike hypersensitivity, including MHC-class II induction (51). The physiologic role of the induction of MHC-class II antigens on grafted tissue is most likely the enhancement of antigen presentation to $T$ helper lymphocytes $(15,16)$. Inhibition of MHC-class II induction may therefore interfere with the effector mechanisms in graft rejection such as DTH and cell-specific cytotoxicity.

The induction of MHC-class II antigens on nonlymphoid tissue is assumed to result 
from IFN- $\gamma$ (9-11), although recently also non-IFN- $\gamma$ MHC-class II inducing factors have been described $(52,53)$. Steroids were reported to inhibit the production of IFN- $\gamma$ (18), which explains the absence of this lymphokine in the presence of high intrarenal drug levels reached in intrarenally treated grafts. By the inhibition of IFN- $\gamma$ production, prednisolone may indirectly affect the induction of MHC-class II antigens on grafted tissue.

It has to be noticed that the absence of IFN- $\gamma$ within the graft may also contribute to prolongation of graft survival in an other way apart from the postulated effect on MHC-class II expression. IFN- $\gamma$ has been described as an activating agent for macrophages (54), and the absence of the lymphokine in certain immune reactions has been associated with reduced macrophage infiltration and function (51). We observed a lower percentage of macrophages within the intrarenally treated grafts; concerning their function however, no direct data were obtained. It has been postulated that steroids interfere with macrophage function e.g., inhibit the production of interleukin 1 and tumor necrosis factor $(55,56)$. To what extent these mechanisms play an essential role during local immunosuppressive treatment has to be examined further.

We observed that high local drug levels of prednisolone did not affect the accumulation of activated (MHC-class II positive) white cells within the graft, while the expression of $I L 2$ receptors on these cells was clearly inhibited. This observation is in concordance to Gillis (17), who demonstrated in vitro that steroids did not prevent cell activation but interfered with IL2 production. Since IL2 receptor expression is strongly induced by IL2 (57), high local drug levels within the graft may interfere with $I L 2$ receptor expression by the inhibition of $I L 2$ production. The inhibition of IL2 receptor expression may be an important mechanism to inhibit cellular immune response, as is suggested by immunosuppressive therapy with monoclonal antibodles against the IL2 receptor $(58,59)$.

In conclusion, intrarenal drug levels most likely did not affect the systemic immune responsiveness against the graft, since cellular infiltration in intrarenally treated grafts was hardly affected. Intrarenal drug levels, however, inhibited intragraft events such as IL2 receptor expression, IFN- $\gamma$ production, and MHC-class II induction on grafted tissue, and in this way prevented rejection. These data strongly support local independence of the cellular immune response within the graft after a certain time, as suggested by others. Second, the data indicate that local treatment of allografts can result in effective immunosuppression. Local manipulation of the immune response by steroids has proven successful in skin disease and inflammatory lung disease. Although the use of steroids in transplantation is also based on their anti-inflammatory effects, which may be of local as well as systemic origin (60), local delivery of the drugs to vascularized organ allografts has hardly been studied, since in man local steroid infusion into the renal artery of kidney transplants was seriously limited by infections and thrombosis $(61,62)$. Recently, however, new types of oral drugs have been developed that allow selective treatment of target organs, e.g. liver or kidney, either by specific tissue binding of the drug or tissue- 
specific activation $(63,64)$. The usefulness of immunosuppressive drugs that fulfil these pharmacologic properties has to be further examined.

Acknowledgments. This work was supported by the Dr. Saal van Zwanenbergstichting, The Netherlands. We thank Mr. J.J. van Dongen and Mrs. E.E.M. Spronken for the excellent technical assistance, and Mrs. C.M.P. Spronck for typing the manuscript.

Abbreviations used in this paper: DTH, delayed-type hypersensitivity; IFN- $\gamma$, interferon-gamma; IL2, interleukin 2; CTL, cytotoxic T lymphocytes; BN, Brown Norway rat; ip, intraperitoneal; MST, median graft survival time; PBS, phosphate buffered saline.

\section{References}

1. Mason, D.W., M.J. Dallman, R.P. Arthur, and P.J. Morris. 1984. Mechanisms of allograft rejection: The roles of cytotoxic $T$ cells and delayed-type hypersensitivity. Immunol. Rev. 77: 167.

2. Tilney, N.L., T.B. Strom, S.G. Macpherson, and C.B. Carpenter. 1975. Surface properties and functional characteristics of infiltrating cells harvested from acutely rejecting cardiac allografts in inbred rats. Transplantation 20: 323 .

3. Tilney, N.L., M.R. Garovoy, G.J. Busch, T.B. Strom, M.J. Graves, and C.B. Carpenter. 1979. Rejected human renal allografts. Recovery and characteristics of infiltrating cells and antibody. Transplantation 28: 421 .

4. Bradley, J.A., D.W. Mason, and P.J. Morris. 1985. Evidence that rat renal allografts are rejected by cytotoxic $T$ cells and not by nonspecific effectors. Transplantation 39: 169.

5. Doweren, R.F.C., W.A. Buurman, C.J. van der Linden, L.W.G. Strijbosch, E.E.M. Spronken, and $\mathrm{G}$. Kootstra. 1986. Analysis of cytotoxic $\mathrm{T}$ lymphocyte response in rejecting allografted canine kidneys. Transplantation 41: 33 .

6. Loveland, B.E., P.M. Hogarth, Rh. Ceredig, and 1.F.C. McKenzie. 1981. Cells mediating graft rejection in the mouse 1. Lyt-1 cells mediate skin graft rejection. J. Exp. Med. 153: 1044.

7. Lowry, R.P., K.E. Gurley, and R.D. Clarke Forbes. 1983. Immune mechanisms in organ allograft rejection. L. Delayed-type hypersensitivity and lymphocytotoxicity in heart graft rejection. Transplantation 36: 391 .

8. Strom, T.B., N.L. Tilney, J.M. Paradysz, J. Bancewicz, and C. B. Carpenter. 1977. Cellular components of allograft rejection: identity, specificity and cytotoxic function of cells infiltrating acutely rejecting allografts. J. Immunoll 118: 2020.

9. Fellous, M., U. Nir, D. Wallach, G. Merlin, M. Rubinstein, and M. Revel, 1982. Interferon dependent induction of mRNA for the major histocompatibility antigens in human fibroblasts and lymphoblastoid cell lines. Proc. Natl. Acad. Sci. U.S.A. 79: 3082.

10. Wong, G.H.W., J. Clark-Lewis, A.W. Harris, and J.W. Schrader, 1984. Erfect of cloned interferon- $\gamma$ on expression of $\mathrm{H}-2$ and la antigens on cell lines of hemopoetic, lymphoid, epithellal, fibroblastic and neuronal origin. Eur. J. Immunol. 14: 52.

11. Pober, J.S., T. Collins, M.A. Gimbrone, R.S. Cotran, J.D. Gitlin, W. Fiers, C. Clayberger, A.M. Krensky, S.J. Burakoff, and C.S. Reiss. 1983. Lymphocytes recognize human vascular endothelial and dermal fibroblasts. Ia antigens induced by recombinant immune interferon. Nature 305: 726 .

12. Milton A.D., and J.W. Fabre. 1985. Massive induction of donor-type class 1 and class II major histocompatibility complex antigens in rejecting cardiac allografts in the rat. J. Exp. Med. 161: 98. 
13. Shearer, G.M., R. Rehn, and C.A. Garbarino. 1975. Cell-mediated lympholysis of trinitrophenylmodiffed autologous lymphocytes: ef fector cell specificity to modified cell suriace cornponents corlltrolled by the $\mathrm{H}-2 \mathrm{~K}$ and $\mathrm{H}-2 \mathrm{D}$ serological regions of the murine major histocompatibility complex. J. Exp. Med. 1.41: 1348 .

14. Alter, B.J., D.J. Schendel, M.L. Bach, F.H. Bach, J. Klein and J. Stimpfling. 1973. Cell-mediated lympholysis. Importance of serologically defined H-2 regions. J. Exp. Med. 1.37: 1303.

15. Engleman, E.G. C.J. Benike, F.C. Grumet, and R.L. Evans. 1981. Activation of human T lymphocyte subsets: helper and suppressor/cytotoxic $T$ cells recognize and respond to distinct histocompatibility antigens. J. Immunol. 127: 2142.

16. Miller, J.F.A.P., M.A. Vadas, A. Whitelaw, and J. Gamble. 1976. Role of major histocompatibility complex gene products in delayed-type hypersensitivity. Proc. Natl.. Acad. Sci. U.S.A. 73: 2486.

17. Gillis, S., G.R. Crabtree, and K.A. Smith. 1979. Glucocorticoid-induced inhibition of T cell growth factor production. I. The effect on mitogen induced lymphocyte proliferation. I. Immunol. 123: 1624.

18. Arya, S.K.,F. Wong-Staall, and R.C. Gallo. 1984. Dexamethasone-mediated inhibition of human T cell growth factor and $\gamma$-interferon messenger RNA. J. Immunol. 133: 273.

19. Hess, A.D., P.J. Tutschka, and G.W. Santos. 1982. Effect of cyclosporin A on human lymphocyte responses in viltro. III. CsA inhibits the production of T lymphocyte growth factors in secondary mixed lymphocyte responses but does not inhibit the response of primed lymphocytes to TCGF. J. Immunol. 128: 35s.

20. Reem, G.H., L.A. Cook, and J. Vileck. 1983. Garnma interferon synthesis by human thymocytes and T lymphocytes is inhibited by Cyclosporin A. Science 221: 63.

21. Hanafusa, T., R. Pujol-Borell, L. Chiovato, R.C.G. Rusell, D. Doniach and G.F. Botazzo. 1983. Aberrant expression of HLA-DR antigens on thymocytes in Grave's disease: relewance for autoimmunity. Lancet 2: 1111.

22. de Waal, R.M.W., M.J.J. Bogman, C.N. Maass, L.M.H. Cornelissen, W.J.M. Tax and R.A.P. Koene. 1983. Variable expression of la antigens on the vascular endothelium of mouse skin grafts. Nature 303: 426,

23. Hall, B.M., G.A. Bishop, G.G. Duggin, J.S. Horvath, J. Philips, and D.J. Tiller. 1984. Increased expression of HLA-DR antigens on renall tubular cells in renal transplants: relevance to the rejection response. Lancet $2: 247$.

24. Sobel, R.A. B.W. Blanchette, A.K. Bahn, and R.B. Colvin. 1984. The immunopathology of experimental allergic encephalomyelitis. II. Endorhelial cell la increases prior to inflammatory cell infïltration. J. Immunol. 132: 2402 .

25. Wadgymar, A., J. Urmson, R. Baumal, and P.F. Halloran. 1984. Changes in la expression in mouse kidney during acute graft vs-host disease. J. Immunol. 132: 1826.

26. Clarke Forbes, R.D., N.A. Parfrey, M. Gomersall, A.G. Darden, and R.D. Guttmann. 1986. Dendritic cell-lymphoid cell aggregation and major histocompatibility antigen expression during rat cardiac allograft rejection. J. Exp. Med. 164: 1239.

27. Sprent, J., and J.F.A.P. Miller. 1976. Fate of $\mathrm{H}-2$ activated T lymphocytes in syngeneic hosts. II. Residence in recirculating lymphocyte pool and capacity to migrate to allografts. Cell. Immunol. $21: 303$.

28. Tilney, N.L., W.L. Ford. 1974. The migration of rat lymphoid cells into skin grafts. Some sensitized cells localize preferentially in specific allografts. Transplantation 17:12.

29. Hall, J.G. 1967. Studies on the cells in the afferent and efferent lymph of lymph nodes draining the site of skin homografts. J. Exp. Med. 125: 737.

30. Ascher N.L., S. Chen, R.A. Hoffman, and R.L. Simmons. 1983. Maturation of cytotoxic T cells within sponge matrix allografts. J. Immunol. $131: 617$.

31. Orosz, C.G., N.E. Zinn, L. Sirinek, R.M. Ferguson. 1986. In vivo mechanisms of alloreactivity. 1 Frequency of donor-peactive cytotoxic T lymphocytes in sponge matrix allografts. Transplantation $41: 75$.

32. Häyry, P.. E. von Willebrand, and A. Soots. 1979. In situ effector mechanisms in rat kidney allograft rejection. III. Kinetics of the inflammatory response and generation of donor-directed killer cells. Scand. J. Immunol. 10: 95.

33. Rivers, T.J.M., W.A. Buurman, F.J.M. Smits, C.J. van der Linden, J.J. van Dongen, H.A.J. Struyker Boudier, and G. Kootstra. 1986. Local treatment of renal allografts, a promising way to recluce the dosage of immunosuppressive drugs. Transplantation 41: 156. 
34. Lee, S., 1967. An improwed technique of renal transplantation in the rat. Surgery $611: 771$.

35. Rose, J.Q., and W.J. Jusko. 1979. Corticosteroid analysis in biological fluids by MPLC. J. Chromatogr. 162: 273 .

36. McMaster, W.R., and A.F. Williams. 1979. Identification of Ia glycoproteins in rat thymus and purification of rat spleen. Eur. J. Immunol. 9:426.

37. Stet, R.J.M., J. Rozing, G.D. Majoor, F.G.M. Kroese, D. Opstelten, and P. Nieusenhuis. 1985. His 19: A monoclonal antibody recognizing a class II polymorphic determinant only absent an RT $^{\mathrm{n}}$ class II antigens. Transplant. Proe. 17: 1829.

38. Dallman, M.J., D.W. Mason, and M. Webb. 1982. The roles of host and donor cells in the rejection of skin allografts by $T$ cell-deprived rats injected with syngeneic $T$ cells. Eur. J. Immunol. 12: 511.

39. Brideau, R.J., P.B. Carter, W.R. McMaster, D.W. Mason, and A.F. Willantas: 1980. Two subsets of rat T lymphocytes defined with monoclonal antibodies. Eur. J. Immunol. 10: 609.

40. Barclay, A.N. 1981. The localization of populations of lymphocytes defined by monoclonal ant:bodies in rat lymphoid tissues. Immunology 42: 593.

41. Cantrell D.A., R.A. Robins, C.G. Brooks and R.W. Baldwin. 1982. Phenotype of rat natural killer cells defined by monoclonal antibodies marking rat lymphocyte subsets. Immunology $45: 97$.

42. Dijkstra, C.D., E.A. Döpp, P. Joling, and G. Kraal. 1985. The heterogeneity of mononuclear phagocytes in lymphoid organs: distinct macrophage subpopulations in the rat recognized by monoclonal antibodies ED1, ED2 and ED3. Immunology 54: 589.

43. Osawa, H., and T. Diamantstein. 1983. The characteristics of a monoclonal antibody that binds specifically to rat $T$ lymphoblasts and inhibits IL2 receptor functions. J. Immunol. 30: 51 .

44. Van der Meide, P.H., M. Dubbeld, K. Vijverberg, T. Kos, and H. Schellekens. 1986. The purification and characterization of rat gamma interferon by use of two monoclonal antibodies. I. Gern. Virol. $67,1059$.

45. McWhinnie D.L., J.F. Thompson, H.M. Taylor, J.R. Chaprnan, E.M. Bolton, N.P Carter, R.F.M. Wood, and P.J. Morris. 1986. Morphometric analysis of cellular infiltration assessed by monoclonal antibody labeling in sequential human renal allograft biopsies. Transplantation 42 : 352.

46. Nemlander, A., A. Soots, E. von Willebrand, B. Husberg, and P. Hayry. 1982. Redistribution of renal allograft-responding leucocytes during rejection. II. Kinetics and specificity. J. Exp. Med. 156: 1087 .

47. Cosini, A.B., R.B. Colvin, R.C. Burton, R.H. Rubin, G. Goldstein, P.C. Kung, W.P. Hansen, F.L. Delmonico, and P.S. Russell. 1981. Use of monoclonal antibodies to T cell subsets for immunologic monitoring and treatment in recipient of renal allografts. $\mathrm{N}$. Eng. J. Med. 305: 308.

48. Morris, P.J., N.P. Carter, P.R. Cullen, J.F. Thompson, and R.F.M. Wood. 1.982. Role of T-cellssubset monitoring in renal allograft recipients. N. Eng. J. Med. 306: 1110,

49. Häyry, P., and $\mathbf{E}$. von Willebrand. 1986 . The influence of the pattern of inflammation and administration of steroids on class II MHC antigen expression in renal transplants. Transplantation 42: 358 .

50. Kaplan, G., M.D. Witmer, 1. Nath, R.M. Steinman, S. Laal, H.K. Prasad, E.N. Sarno, U. Elvers, and Z.A. Cohn. 1986. Influence of delayed immune reactions on human epidermal keratinocyles. Proc. Nati. Acad. Sci. USA 83: 3469.

51. Nathan, C.F., O. Kaplan, W.R. Levis, A. Nusrat, M.D. Witmer, S.A. Sherwin, C.K. Job, F.lR.C. Path, C.R. Horowitz, R.M. Steinman, and Z.A. Cohn. 1986. Local and systemic effects of intradermal recombinant interferon- $\gamma$ in patients with lepromatous leprosy. N. Eng. I. Med. 315: 6.

52. Groenewegen, G., M. de Ley, G.M.A.A. Jeunhomme, and W.A. Burman. 1986. Supernatants

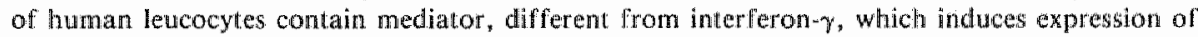
MHC-class 11 antigens. J. Exp. Med. 164: 131.

53. Walker, E.B., V. Maino, M. Sanchez-Lanier, N. Warner, and C. Stewart. 1984. Murine gamma interferon activates the release of a macrophage derived la inducing factor that transfers la induc. tive capacity. J. Exp. Med. 159: 1532.

54. Nathan, C.F., H.W. Murray, M.E. Wiebe, and B.Y. Rubin. 1983. Vdentification of interferon $\gamma$ as the lymphokine that activates human macrophage oxidative metabolism and antimicrobial activity. J. Exp. Med. 158: 670 .

55. Snyder, D.S., and E.R. Unanue. 1982. Corticosteroids inhibit murine macrophage la expression and interleukin 1 production. J. Immunol. 129: 1803. 
56. Beutler, B., N. Krochin, 1.W. Milsark, C. Luedke, and A. Cerami. 1986. Control of Cachectia (turnor necrosis factor) synthesis: mechanisms of endotoxin resistance. Science 232: 977.

57. Reem, G.H., and N.H. Yeh. 1984. Interleukin 2 regulates the expression of its receptor and the synthesis of gamma interferon by human T cells. Science 225: 429 .

58. Kirkman, R.L., L.V. Barrett, G.N. Gaulton, V.E. Kelley, A. Ythier, and T.B. Strom. 1985. Administration of an anti interleukin 2 receptor monoclonal antibody prolongs cardiac allograft surviwal in mice. J. Exp. Med. 162: 358.

59. Hancock, W.W., R.H. Lord, A.J. Colby, T. Diamantstein, F.R. Rickles, C. Dijkstra, N. Hogg, and N.L. Tilney. 1987. Identification of $1 \mathrm{~L}-2 \mathrm{R}^{+} \mathrm{T}$ cells and macrophages within rejecting rat carciac allografts, and comparison of the effects of treatment with anti IL $2 \mathrm{R}$ monoclonal antibody or cyclosporin. J. Immunol. 138: 164.

60. Cupps, T.R., and A.S. Fauci. 1982. Corticosteroid-mediated immunoregulation in man. Immunol. Rev. 65: 133 .

61. Kountz, S.L., and R. Cohn. 1969. Initial treatment of renal allografts with large intrarenal doses of immunosuppressive drugs. Lancet 1: 338.

62. Laupacis, A., P.A. Keown, R.N. Raukin, R. Gold, R.A. Ulan, and C.R. Stiller. 1982. Intraarterial methylprednisolone and Heparin (IAT) for the treatment of refractory renal transplant rejection episodes. Transplant. Proc. 14: 693.

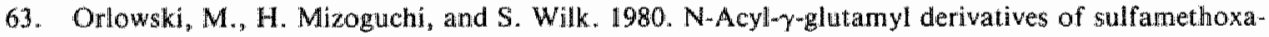
zolle as models of kidney gelective prodrugs. J. Pharmacol. Exp. Ther. 212: 167.

64. Bundgaard, H. 1985. Design of pro-drugs. H. Bundgaard, editor. Elsevier Science Publishers B.V., Amsterdam. 


\section{The effect of local immunosuppression, in the absence of significant systemic immunosuppression, on rat cardiac allograft survival.}

Accepted for publication in Transplantation; in press december 1988, entitled

"Graft rejection in rats proves sensitive to local immunosuppressive therapy".

\section{Summary}

In this study we investigated whether allograft rejection is sensitive to local immunosuppressive therapy. In rats, cardiac transplantations (BN $\rightarrow$ Lewis) were performed with venous return on the portal vein of the recipient. For local treatment the topical steroid budesonide was infused with an osmotic minipump directly into the carotid artery of the transplant. Budesonide is rapidly cleared by the liver, and cardiac tissue binding of the drug is high. Hence, local budesonide administration, $120 \mu \mathrm{g} / \mathrm{kg}$ body weight/day, resulted in high drug levels within the graft $(29.6$ $\mathrm{ng} / \mathrm{mg}$ ) and low systemic drug levels $(0.34 \mathrm{ng} / \mathrm{ml})$. Systemic drug levels were so low that systemic biological effects of the drug during local administration were not measurable. In contrast systemic drug delivery, via the jugular vein of the recipient, resulted in similar drug levels within the graft $(31.0 \mathrm{ng} / \mathrm{mg})$, but with high systemic drug levels $(1.65 \mathrm{ng} / \mathrm{ml})$ and important systemic side effects. Both local and systemic administration of budesonide, $120 \mu \mathrm{g} / \mathrm{kg}$ body weight/day for 13 days, resulted in significant prolongation of graft survival; median graft survival time was respectively 19.5 days and 20.0 days, compared with 7 days in controls. These results demonstrate that allograft rejection can be treated locally without significant systemic immunosuppression. 


\section{Introduction}

In organ transplantation systemic side effects of immunosuppressive drugs often are a major impediment to successful therapy. The combination of conventional immunosuppressive drugs such as steroids and azathioprine results in a high incidence of infections and serious metabolic side effects (1). More specific immunosuppression, as obtained by recently introduced immunosuppressive drugs such as cyclosporine and anti $\mathrm{CD} 3$ monoclonal antibodies was therefore highly desirable (2-4). However, induction of local immunosuppression within the graft may be an alternative approach to reduce systemic side effects during immunosuppressive therapy. This approach avoids systemic immunosuppression leading to a compromised host, as well as reducing other side effects of the drug administered.

Recently it has been suggested that both the induction of the immune response by major histocompatibility complex (MHC) antigens (5-7) and the effector mechanisms during cellular immune response (8-11) are regulated locally within the graft. The postulated local regulation of the immune response within the graft makes the affected organ a favourable object for local immunosuppressive therapy. Local treatment can be performed by direct infusion of the drug into the artery supplying the transplanted organ as well as by site-specific drug delivery employing pharmacological principles such as tissue-specific binding or tissue-specific drug activation (12). The effect of local drug administration to renal allografts has been studied in man and rodents (13-16). In these studies the infusion of steroids directly into the renal artery of the transplant proved to be superior to systemic administration of the drug. However, due to pharmacological properties of the drugs used, significant systemic drug levels were still obtained during intrarenal infusion.

The aim of this study was to determine more precisely the potency of local immunosuppressive therapy alone. For this purpose an experimental transplantation model was developed in which local immunosuppression could be induced without systemic immunosuppression. Cardiac allografts were transplanted in such a way that venous blood flow from the graft directly passed to the liver of the recipient via the portal vein. Local immunosuppression was induced by infusion of the steroid budesonide directly into the artery supplying the cardiac transplant. The steroid budesonide shows a high cardiac tissue binding and is extremely rapidly cleared from the plasma by the liver $(17,18)$. The pharmacological properties of the drug in combination with the characteristics of the transplantation model made it possible to measure accurately the effect of local immunosuppression in the absence of systemic immunosuppression.

\section{Materials and methods}

Animals. All experiments were carried out with inbred Brown Norway (RT") and Lewis ( $\mathrm{RT}^{\mathrm{L}}$ ) male rats, between 2-3 months of age, obtained from the Depariment 


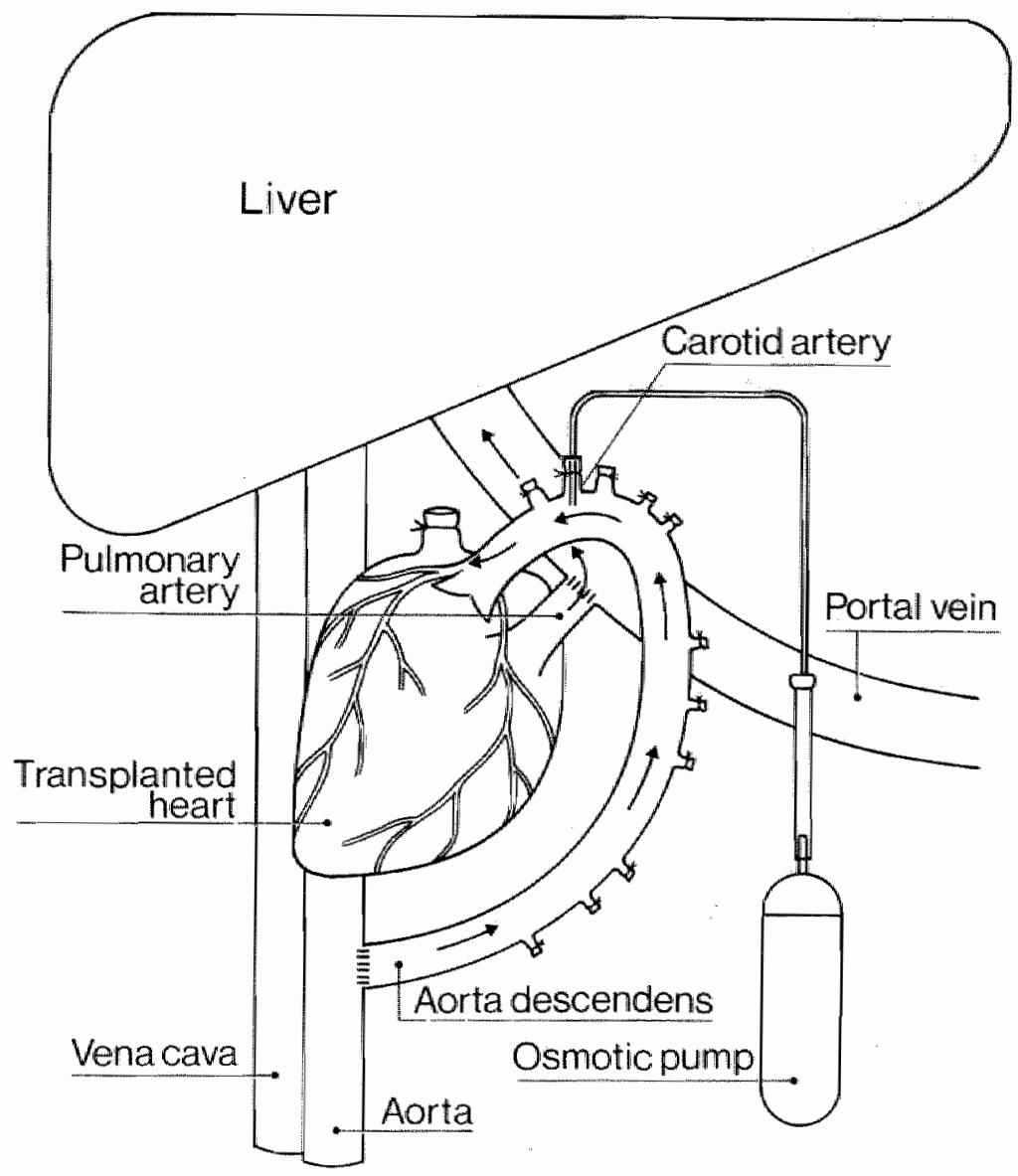

FIGURE 1. Schematic outline of the experimental model used. Cardiac rransplanis were performed with end-to-side anastomosis between donor descending aorta and recipient abdominal aoria. Venous oulflow was created by end-to-side anastomosis between donor pulmonary artery and recipient portal vein. In the transplantation model blood flow is reversed as indicated. For Jocal drug administration a catheter was introduced into the left carotid artery of the transplanted aorta and connected to an asmotic mimipump.

of experimental animal services of the University of Limburg. Rats were supplied with acidified water and rat chow ad libitum.

Cardiac transplantation. Heterotopic cardiac transplantation was performed from Brown Norway (BN) to Lewis strain rats using microsurgical techniques, while the heart of the recipient animal remained functionally in situ. Donor hearts were anastomosed to the recipient using an end-to-side anastomosis between donor 
descending aorta and recipient abdominal aorta. Venous outflow was created by end-to-side anastomosis between donor pulmonary artery and recipient portal vein (Figure 1).

In this heart transplantation model blood flow is reversed in the thoracic aorta: The aortic valves are automatically closed and blood runs via the coronary arteries, myocardium and coronary veins into the right atrium and ventricle (19). Venous blood passes via the pulmonary artery into the portal vein and enters the liver.

Immunosuppressive treatment. Budesonide (kindly provided by Draco, Lund, Sweden) was administered by continuous infusion either systemically or locally directly into the transplanted heart. For local administration of the drug the left carotid artery of the transplanted aorta was cannulated with a polyethylene 10 tube (Clay Adams, Parsippany, NJ) (Figure 1). Immediately after transplantation the catheter was connected to an Alzet osmotic minipump (model 2ML2, Alza, Palo Alto, CA) implanted into the abdominal cavity. Pumps delivered budesonide at a constant rate of $6 \mu \mathrm{l} / \mathrm{hr}$ from day 0 till day 13 after transplantation. Continuous systemic drug administration was performed via a Silastic catheter (602-155 Silastic tubing Dow Corning, Midland, MI) introduced into the jugular vein, guided to the abdominal cavity, and connected to the osmotic minipump. Budesonide was dissolved in pyrogen-free distilled water plus propandiol $66 \%$ without heparin and dosage of the drug was adjusted to body weight of the recipient at day -1 . In all animals correct position of the catheter was checked at autopsy. Heartbeat was checked daily by palpation through the abdominal wall, and rejection was taken as the complete absence of ventricular contraction. Rejection was confirmed by histopathological examination.

Pharmacokinetic studies. For information on the budesonide levels reached during both types of therapy, pharmacokinetic studies were performed. Recipients of cardiac allografts were treated with budesonide $120 \mu \mathrm{g} / \mathrm{kg}$ body weight/day given either by continuous local infusion or by continuous systemic infusion. Pharmacokinetic studies were performed on day 5 after transplantation. At that time animals were given pentobarbital anesthesia while the trachea was cannulated to ensure a patent airway. The osmotic minipumps were disconnected from the catheter and replaced by an external infusion pump (Type 5003, Precidor infors AG, Basel) filled with ${ }^{3} \mathrm{H}$-budesonide in addition to cold unlabeled budesonide. Infusion lasted for $5 \mathrm{hr}$ at a constant rate of $25 \mathrm{ng} / \mathrm{min}$, which equals a total amount of budesonide of $120 \mu \mathrm{g} / \mathrm{kg}$ body weight/day. In animalls treated locally the quantity of ${ }^{3} \mathrm{H}$-budesonide infused was $3.7 \times 10^{5} \mathrm{dpm} / \mathrm{min}$ (i.e. $1 \mathrm{ng} / \mathrm{min}$ ). In animals treated systemically $0.74 \times 10^{5} \mathrm{dpm} / \mathrm{min}$ (i.e. $0.2 \mathrm{ng} / \mathrm{min}$ ) of ${ }^{3} \mathrm{H}$-budesonide was administered. Preliminary experiments had shown that steady state was achieved after $5 \mathrm{hr}$ of infusion. Therefore arterial blood sampling, via a femoral arterial catheter, was performed at $t=300 \mathrm{~min}$. Samples were collected into heparinized glass vessels, and after centrifugation plasma was stored at $-20^{\circ} \mathrm{C}$ until assay. Subsequently 
the animal was killed and the graft was removed, washed in saline, weighed and stored at $-20^{\circ} \mathrm{C}$. During the experiments the body temperature was measured in the rectum and maintained at $37.5^{\circ} \mathrm{C}$ by a thermostatically controlled heat lamp. For measurements of blood flow to the cardiac allograft, an electromagnetic flow probe (internal diameter $1.8 \mathrm{~mm}$, Skalar, Delft, The Netherlands) was placed around the transplanted aorta. Flow signals were measured with a sinewave flow meter (type MDL 400, Skalar, Delft, The Netherlands) and recorded. Budesonide concentrations were measured in plasma, which equals blood concentrations as reported earlier (18). Unchanged ${ }^{3} \mathrm{H}$-budesonide was quantified by adding an internal standard solution (unlabeled budesonide) to each plasma sample. Extraction was performed with dichloromethane, the organic phase was evaporated, and the residue dissolved in the mobile phase used in the HPLC analysis. Standardization was performed by adding known amounts of ${ }^{3} \mathrm{H}$-budesonide to blank plasma. Using this extraction procedure, a quantitative recovery $(95 \pm 2 \%)$ of unchanged ${ }^{3} \mathrm{H}$-budesonide is obtained, as well as a sufficiently clean sample for direct HPLC injection $(18,20)$. HPLC was performed with a Nucleosil C18 $(5 \times 200 \mathrm{~mm})$ analytic column with ethanol/ water $45 / 55(\mathrm{v} / \mathrm{v})$ as the mobile phase $(18) .{ }^{3} \mathrm{H}$-budesonide was measured in a liquid scintillation counter. For measurements of ${ }^{3} \mathrm{H}$-budesonide in cardiac allografts, the heart tissue was homogenized in 4 times its volume $(\mathrm{w} / \mathrm{v}) 0.9 \% \mathrm{NaCl}$. ${ }^{3} \mathrm{H}$-budesonide was extracted from the tissue and measured as described above. The total concentration of unchanged budesonicle was calculated from the amount of unchanged ${ }^{3} \mathrm{H}$-budesonide measured by HPLC.

Pharmacokinetic analysis. The systemic plasma clearance (CL) of intravenously administered budesonide is given by;

$\mathrm{CL}(\mathrm{ml} / \mathrm{min})=\frac{\inf }{\mathrm{Cs}}$

where inf equals the infusion rate $(\mathrm{ng} / \mathrm{min})$ and $\mathrm{Cs}$ the systemic arterial steady-state plasma concentration $(\mathrm{ng} / \mathrm{ml}$ ). The systemic plasma clearance of local administered budesonide is calculated by;

$\mathrm{CL}(\mathrm{ml} / \mathrm{min})=\frac{(1-\mathrm{E}) \times \mathrm{inf}}{\mathrm{Cs}}$

where $E$ represents the extraction ratio of the drug by the liver, and (1-E) equals the quotient of $\mathrm{Cs}$ derived from local and systemic budesonide infusion (21).

Measurements of systemic side effects. To measure the systemic side effects of budesonide treatment exclusively and avoid the simultaneous effects of cardiac transplants on the immune system, toxicity studies were performed in normal Lewis rats. For comparison of results however, budesonide $(120 \mu \mathrm{g} / \mathrm{kg}$ body weight $/$ day) was given by continuous infusion directly into the portal vein or by continuous infu- 
sion into the jugular vein. In this way experiments resemble, respectively, the situation during local and systemic budesonide infusion in the transplanted animals. For continuous infusion into the portal vein a silastic catheter was introduced into the portal vein, secured by a purse-string suture, and connected to an osmotic minipump. Electromagnetic flow measurements showed that portal blood flow was not affected by this procedure (data not given). Continuous infusion into the jugular vein was performed as described above. Budesonide was administered for 10 days, after which time body weight, spleen weight, thymus weight, adrenal weight, and total leukocyte count were determined. Control animals received continuous infusion of the solvent (propandiol 66\%) directly into the portal vein for 10 days.

Statistical analysis. The Wilcoxon rank test was used to compare differences between experimental groups. Differences were considered to be statistically significant if $p<0.05$ in a two-tailed test.

\section{Results}

Graft survival. To study the effect of local budesonide therapy on cardiac allograft survival, various budesonide treatments were tested (Table 1). Budesonide was administered by continuous local infusion or continuous systemic infusion and dose-response studies were performed at dosages of 40,90 , and $120 \mu \mathrm{g} / \mathrm{kg}$ body weight/day. Pilot experiments had revealed that at dosages below $40 \mu \mathrm{g} / \mathrm{kg}$ body weight/day graft survival was not significantly affected by the drug when administered locally or systemically. To determine the effect of the local infusion technique on cardiac allograft survival Lewis recipients were untreated or received continuous local infusion of the solvent (propandiol 66\%). Median graft survival time (MST) in animals treated with continuous local infusion of the solvent was 7 days, which equals MST in untreated controls (legend Table 1). Thus the local infusion technique itself has no detrimental or enhancing effect on cardiac allograft survival. Local administration of budesonide, however, resulted in significant prolongation of graft survival at all dosages tested. Moreover a clear dose-response effect was observed: with increasing dosages MST was increased. At the highest dosage tested MST was prolonged to 19.5 days, and the mean interval between withdrawal of treatment (day 13) and rejection was 6.5 days. In order to compare the potency of local drug delivery to systemic drug delivery, budesonide was also administered by continuous intravenous infusion. As demonstrated in Table 1 systemic drug delivery resulted in MST almost equal to that observed after local drug administration. These data demonstrate that local budesonide administration is as effective as systemic budesonide administration. According to these results, however, it is essential to ascertain that local immunosuppression by itself is responsible for the immunosuppressive effect obtained. Hence, to exclude systemic immunosuppression during local drug administration, pharmacokinetic studies were performed. 
TABLE 1. The effect of various budesonide treatments upon heart allograft survival

\begin{tabular}{|c|c|c|c|c|}
\hline \multirow{2}{*}{$\begin{array}{l}\text { Budesonide } \\
\mu \mathrm{g} / \mathrm{kg} \text { body } \\
\text { weight/ } \\
\text { day }\end{array}$} & \multicolumn{2}{|c|}{ Continuous locally } & \multicolumn{2}{|c|}{ Continuous iv. } \\
\hline & $\begin{array}{l}\text { Graft } \\
\text { survival } \\
\text { (days) }\end{array}$ & $\mathrm{MST}^{\mathrm{a}}$ & $\begin{array}{l}\text { Graft } \\
\text { survival } \\
\text { (days) }\end{array}$ & MST \\
\hline 40 & $\begin{array}{l}11,12,13,13 \\
14,15,16,20\end{array}$ & $13.5 \pm 2.9^{b}$ & $\begin{array}{l}8,9,12,13 \\
14,14,22\end{array}$ & $13 \pm 4.6^{b}$ \\
\hline 90 & $\begin{array}{l}15,16,16 \\
18,18\end{array}$ & $16 \pm 1.5^{b}$ & $\begin{array}{l}13,16,16 \\
16,18,19,22 .\end{array}$ & $16 \pm 3.1^{b}$ \\
\hline 120 & $\begin{array}{l}15,17,18,19 \\
20,20,21,21\end{array}$ & $19.5 \pm 2.2^{b}$ & $\begin{array}{l}17,17,18,19 \\
21,22,22,23 .\end{array}$ & $20 \pm 2.4^{b}$ \\
\hline
\end{tabular}

a $\quad$ MST $=$ median graft survival time \pm S.D.

b Wilcoxon rank rest for difference between animals treated with budesonide and animals treated with the solvent $(p<0.01)$.

- Control animals were untreated or received continuous local infusion of the solvent. In both groups MST" was 7 days. Graft survival times (in days) in the untreated group were $6,6,6,7,7,8,8,9$; graft survival times (in days) in the group treated locally with the solvent were $6,7,7,7,7,8,10,12$.

- Rejection was taken as the complete absence of ventricular contraction and was confirmed by histopathological examination.

Pharmacokinetic studies. Transplanted rats were treated with budesonicle at the concentration of $120 \mu \mathrm{g} / \mathrm{kg}$ body weight/day given by either continuous local or continuous systemic infusion. On day 5 after transplantation, tissue and plasma levels of unchanged budesonide were determined as described. Table 2 summarizes the plasma and tissue levels of budesonide in a steady-state condition. Local administration of the drug resulted in a mean plasma level of $0.34 \mathrm{ng} / \mathrm{ml}$, which was significantly lower than $1.65 \mathrm{ng} / \mathrm{ml}$ measured in systemically treated animals. The tissue levels in the transplanted hearts were almost equal with local and systemic drug administration, and measured, respectively, $29.6 \mathrm{ng} / \mathrm{mg}$ and $31.0 \mathrm{ng} / \mathrm{mg}$. During both types of drug administration blood flow through the graft and plasma (blood) clearance of budesonide were equal. The quotient of the systemic plasma concentrations measured during local and iv administration (Cs local/Cs systemic) is 0.2. This quotient, which equals 1-E, represents the reduction in systemic concentration during local as compared with systemic administration of the drug as the result of the firstpass effect of liver extraction. The extraction ratio of budesonide by the liver (E) is high and equals 0.8 .

Systemic biological effects. The systemic biological effects of the low plasma levels measured during local treatment were analyzed. For this purpose normal rats were 


\begin{tabular}{lll}
\hline & $\begin{array}{l}\text { continuous } \\
\text { locally }\end{array}$ & continuous iv. \\
\hline Infusion rate & $25 \mathrm{ng} / \mathrm{min}$ & $25 \mathrm{ng} / \mathrm{min}$ \\
Blood flow through graft & $7.2 \pm 0.5 \mathrm{ml} / \mathrm{min}$ & $7.2 \pm 0.5 \mathrm{ml} / \mathrm{min}$ \\
Systemic plasma (blood) concentration & $0.34 \pm 0.1 \mathrm{ng} / \mathrm{ml}$ & $1.65 \pm 0.6 \mathrm{ng} / \mathrm{ml}^{\mathrm{b}}$ \\
Concentration in graft & $29.6 \pm 10.1 \mathrm{ng} / \mathrm{mg}$ & $31.0 \pm 11.0 \mathrm{ng} / \mathrm{mg}^{c}$ \\
Plasma (blood) clearance & $15.2 \mathrm{ml} / \mathrm{min}$ & $15.2 \mathrm{ml} / \mathrm{min}$
\end{tabular}

Cs loc./Cs syst.

0.2

a After transplantation animals were treated for 5 days with budesonide $120 \mu \mathrm{g} / \mathrm{kg}$ body weight/day given by continuous local infusion or continuous iv infusion. At day 5, pharmacokinetic studies were performed. "H-budesonide and, cold unlabeled budesonide were infused together for $5 \mathrm{hr}$, while total budesonide concentration remained $120 \mu \mathrm{g} / \mathrm{kg}$ body weight/day. At $t=300$ min, plasma levels and tissue levels of unchanged ${ }^{3} \mathrm{H}$ budesonide were determined by means of HPLC. Budesonide concentrations are given as the total amount of unchanged budesonide calculated from the amount of unchanged ${ }^{3} \mathrm{H}$-budesonide measured by HPLC. Animals weighed $300 \mathrm{~g} \pm 10 \mathrm{~g}$, per group $n=6$. All data given are mean values $\pm S D$.

bilcoxon rank test for difference between plasma levels in animals treated locally and intravenously $p<0.01$.

" Expressed in ng per mg tissue.

treated with budesonide at a concentration of $120 \mu \mathrm{g} / \mathrm{kg}$ body weight/day for 10 days. At that time body weight, spleen weight, thymus weight, adrenal weight, and leukocyte count were determined. Normal Lewis rats were chosen to exclude the effect of the cardiac transplant on the immune system. In these nontransplanted animals the drug was either given directly into the portal vein or, for comparison of results, systemically into the jugular vein. As shown in Table 3, budesonide delivered directlly into the portal vein, which mimics the situation during local graft treatment, did not induce systemic toxicity. All data obtained in this group were similar to the data of control animals, which were treated with the solvent (propandiol $66 \%$ ) administered directly into the portal vein. In contrast, however, budesonide administered systemically showed strong systemic toxicity. Body weight, spleen weight, thymus weight, and adrenal weight of the systemically treated animals were significantly lower than those of the control animals and the animals treated with budesonide administered directly into the portal vein. 
TABLE 3. Systemic biological effects of budesonide with different methods of admingtration $^{a}$

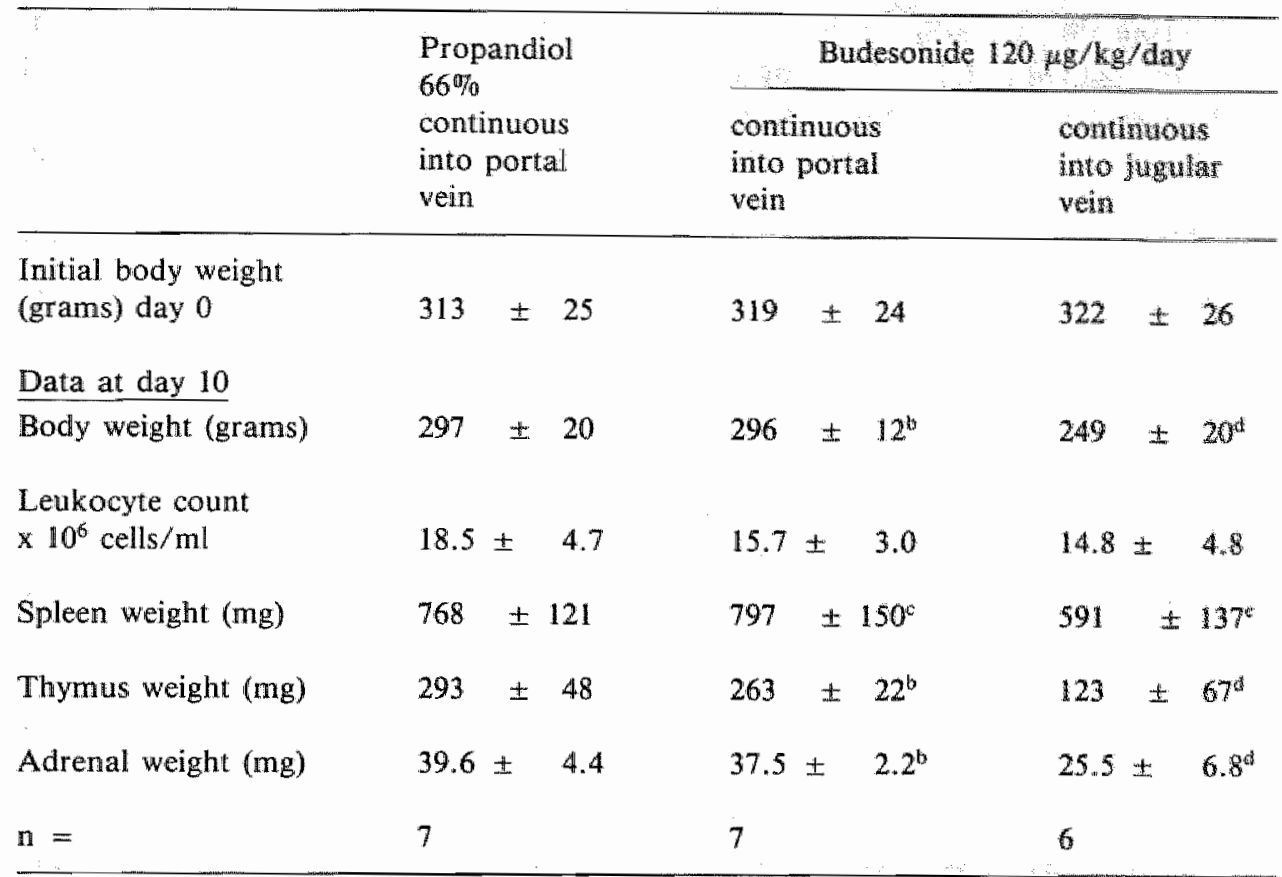

- Normal Lewis rats received budesonide by contimuous infusion into the jugular wein or by continuous infusion into the porial vein. Control animals received propandiol $66 \%$ by continuous infusion into the portal vein. All data given are mean walues $\pm S D$.

B.c Wilcoxon rank test for difference between animals treated with budesonide administered into the portal vein and animals treated with budesonide administered into the jugular vein: $p<0.01 ., " p<0.05$.

Differences between control animals and animals treated with budesonide administered into the portal vein, were not significant.

dite Wilcaxon rank test for difference between animals treated with budesonide administered into the jugular vein and control animals: ${ }^{d} p<0.01, p<0.05$.

\section{Discussion}

The purpose of this study was to determine the effect of local immunosuppression in the absence of or in the presence of minimal systemic immunosuppression. Therefore a transplantation model was developed that offers optimal conditions for local graft treatment. In this model the venous outflow from the transplanted heart enters directly into the liver of the acceptor animal and hence great advantage of local drug administration can be obtained for immunosuppressive drugs that have a high hepatic clearance. When such drugs are administered directly to the transplanted heart, high drug levels can be obtained within the graft while the systemic concentration of the drug will be low because of the high first-pass effect by the liver. The 
steroid budesonide is known to be rapidly cleared by the liver (18) and seems, therefore, to be an attractive candidate for local drug administration. In man and rodents this steroid shows strong antiinflammatory effects and is used in treatment of asthmatic patients $(22-25)$. Inhalation of the drug results in high topical potency and no or marginal systemic side effects $(24,25)$.

Local administration of budesonide in the transplantation model resulted in drug plasma levels 5 times lower than during systemic administration of the drug, while levels within the graft were similar with both types of administration. The induction of local immunosuppression was enhanced by the high binding of the drug to the transplanted heart. The levels of budesonide within the graft were 90 to 20 times higher than the corresponding plasma levels of the drug in the locally and systemically treated groups, respectively. Selective cardiac tissue binding of budesonide was reported earlier by Andersson after iv infusion of the drug in mice (17). Although expected from earlier observations with intrarenal administration of prednisolone $(15,16)$, local administration of budesonide did not result in higher local drug concentrations than systemic drug delivery, most likely because of this high selective tissue binding of the drug. Budesonide in this regard behaves completely differently from the immunosuppressive steroid prednisolone, which did not show selective tissue binding (16). The extraction ratio of budesonide by the liver was found to be 0.8 , indicating that $80 \%$ of the budesonide delivered to the liver is cleared before entering the systemic circulation, which is in concordance to earlier observations in man (18). During local drug administration body weight, spleen weight, thymus weight, adrenal weight, and leukocyte count were similar to those in control animals, which shows that the first-pass effect by the liver resulted in such low plasma levels of budesonide that systemic biological effects were not measurable. This finding also indicates that the metabolic products of budesonide are minimally or even not biologically active, which is in agreement with earlier observations (26). Thus the characteristics of the transplantation model used, together with the pharmacokinetics of budesonide offered the possibility of inducing local immunosuppression in the graft without significant systemic biological effects.

Local immunosuppression, as induced during local drug administration, resulted in significant prolongation of cardiac allograft survival. At a dosage of $120 \mu \mathrm{g} / \mathrm{kg}$ body weight/day MST was 19.5 days, which means that the mean interval between withdrawal of treatment and rejection (6.5 days) almost equalled MST in control animals (7 days). It is of interest that the addition of systemic immunosuppression, as occurs during systemic administration of the same dose of budesonide, did not result in a better MST. Even in dose-response studies no significant difference could be observed in MST between animals treated locally and systemically. In conclusion, these findings demonstrate that graft rejection can be treated locally without apparent systemic immunosuppression. On the other hand, the data presented strongly support a central role of local regulatory mechanisms during allograft rejection, as postulated by others $(5-11,27)$. 
Studies with sponge matrix allografts showed that a few days after transplantation lymphocytes mature and proliferate within the graft independent of the host; which implies a central role for local regulation of the immune response e.g., by local production of lymphokines (9). Moreover it was reported that local production or local administration of the lymphokine interferon- $\gamma$ induces local expression of $\mathrm{MHC}$-class II antigens on surrounding tissue (28). The induction of these antigens plays an essential role during the initiation phase, as well as during the effector phase of the immune response $(6,29-32)$. In this study no data are presented concerning the mechanism by which local budesonide interferes with these local regulatory mechanisms. In vitro studies, however, of the actions of steroids, demonstrated that these drugs strongly inhibit the production of lymphokines such as interferon- $\gamma$ and interleukin $2(33,34)$. Further, it has been suggested that inhibition of lymphokine production within the graft interferes with the induction of MHC-class II antigens on grafted tissue and hence prevents graft destruction (7). From these observations it can be speculated that local budesonide treatment may interfere with the initiation, as well as with the effector phase, of the immune response.

In clinical practice the use of immunosuppressive drugs is limited by their serious systemic side effects. Hence, the purpose of local immunosuppression in organ transplantation should be the reduction of systemic side effects without losing immunosuppressive effect. In this study local immunosuppression was induced by local drug administration via a catheter. In transplant patients this method had serious drawbacks, such as infection or thrombosis $(13,14)$. Nowadays, however, drug administration via intra-arterial biocompatible catheters by means of programmable implantable infusion pumps may become clinically applicable to obtain high local drug levels in combination with low systemic drug levels. For drugs with a high hepatic clearance, such as budesonide, even oral administration can be used for selective treatment of liver transplants. However, site-specific drug delivery can also be performed by tissue-specific drug binding or tissue- specific drug activation. Recently new types of oral drugs have been developed (pro-drugs) that are by themselves inactive; within the specific organ e.g. kidney or liver, however, they undergo change into the active drug, for example by local enzymatic reactions highly specific to the organ $(12,35,36)$. If the plasma clearance of the active compound is high, this approach results in high local drug levels and low systemic drug levels.

In this study we show for the first time that allograft rejection can be treated by local immunosuppression in the absence of significant systemic immunosuppression. According to these results, the development of immunosuppressive therapies that permit localized immunosuppression of certain defined grafts such as kidney or liver would reduce morbidity in transplant patients, and in this way would open new perspectives in clinical immunosuppressive treatment.

Acknowledgments. This work was supported by the Dr. Saal van Zwanenbergstichting. We thank Dr. W. Dinjens and Dr. M. Havenith of the Department of Pathology for the histopathological examination of the transplanted hearts. Draco, 
Lund, Sweden, is acknowledged for generously providing budesonide, and Mrs. K. Spronck for superb secretarial assistance.

\begin{abstract}
Abbrewiations used in this paper: $\mathrm{BN}$, Brown Norway; $\mathrm{Cl}$, plasma clearance; $\mathrm{C} s$, systemic plasma concentration; $\mathrm{E}$, extraction ratio; inf, infusion rate; $\mathrm{MHC}$, major histocompatibility complex; MST, median graft survival time.
\end{abstract}

\title{
References
}

1. d'Apice AJ. Non-specific immunosuppression: Azathioprine and steroids. In: Morris PJ, ed., Kidney transplantation, principles and practice. (2nd edition) London: Grune and Stratton, 1984: 239.

2. Caine RY, Rolles $K$, Thiru $S$, et al. Cyclosporin $A$ initially as the only immunosuppressant in 34 recipients of cadaveric organs: 32 kidneys, 2 pancreases and 2 livers. Lancet 1979;2: 1033.

3. European Multicentre Trial Group. Cyclosporin in cadaveric renal transplantation: one-year follow-up of a multicentre trial. Lancet $1983 ; 2: 986$.

4. Ortho Multicenter Transplant Study Group. A randomized clinical trial of OKT3 monoclonal antibody for acute rejection of cadaveric renal transplants. N. Eng. J. Med. 1985; 313: 337.

5. de Waal RM, Bogman MJJ, Maass CN, Cornelissen LMH, Tax WJ, Koene RAP. Variable expression of la antigens on the vascular endothelium of mouse skin allografts. Nature $1983 ; 303: 426$.

6. Hall BM, Duggin GG, Philips J, Bishop GA, Horvath JS, Tiller DJ. Increased expression of HLADR antigens on renal tubular cells in renal transplants: relevance to the rejection response. Lancet $1984 ; 2: 247$.

7. Häyry $P$, won Willebrand $E$. The influence of the pattern of inflammation and administration of steroids on class II MHC antigen expression in renal transplants. Transplantation 1986; $42: 358$.

8. Nemlander A, Soots A, won Willebrand E, Husberg B, Häyry P. Redistribution of renal allograftresponding leucocytes during rejection: II. Kinetics and specificity; J. Exp. Med. 1982; 156: 1087.

9. Ascher NL, Chen S, Hoffman RA, Simmons RL. Maturation of cytotoxic I cells within sponge matrix allografts. J. Immunol. 1983; 131: 617.

10. Orosz CG, Zinn NE, Sirinek LP, Ferguson RM. In vivo mechanisms of alloreactivity: 1. Frequency of donorreactiwe cylotoxic $T$ lymphocytes ir sponge matrix allografts. Transplantation 1986; 41 : 75 .

11. Orosz CG, Zinn NE, Sirinek LP, Ferguson RM. In wivo mechanisms of alloreactivity: II. Allospecificity of cytotoxic $T$ lymphocytes in sponge matrix allografts as determined by limiting dilution analysis. Transplantation $1986 ; 41: 84$.

12. Bundgaard H. Design of pro-drugs. Amsterdam: Elsevier 1985.

13. Kountz SL, Cohn $\mathbb{R}$. Initial treatment of renal allografts with large intrarenal doses of immunosuppressive drugs. Lancet $1969 ; 2 ; 338$.

14. Laupacis A, Keown PA, Rankin RN, Gold R, Ulan RA, Stiller CR. Intra-arterial methylprednisolone and heparin for the treatment of refractory renal transplant rejection episodes. Transplant Proc 1982; 14: 693.

15. Ruers TJM, Butman WA, Smits JFM, et al. Local treatment of renal allografts; a promising way to reduce the dosage of immunosuppressive drugs; comparison of various ways of administering prednisolone. Transplantation $1986 ; 41 ; 156$.

16. Ruers TJM, Buurman WA, Van Boxtel CJ, Van der Linden CJ, Kootstra G. Immunohistological observations in rat kidney allografts following local steroid administration. J. Exp. Med. 1987; 166; 1205.

17. Andersson P, Appelgren LE, Ryrfeldt $\ddot{A}$. Tissue distribution and fate of budesonide in the mouse. In: Andersson $\mathbb{P}$. Structural aspects on the metabolism of glucacorticosteroids. (Thesis) Lund, Sweden: University of Lund, 1986: 147. 
18. Ryrfeldt $\mathbb{A}$., Andersson $\mathbb{P}$, Edsbäcker S, Tönnesson $M$, Davies $M$, Pauwels $R$. Pharmatokinetics and metabolism of budesonide, a selective glucocorticoid. Eur. J. Respir. Dis. 1982; 63 (suppl 122): 86.

19. Boecks $W$, Vandeputte $M$. Technique of rat heart transplantation providing pulmoportal venous outlet. In: Proceedings of the International Microsurgery Society, Human development, Honolulu: East Ine. 1974; 57.

20. Ryrfeldt A., Tönnesson M, Nilsson E, Wikby A. Pharmacokinetic studies of a potent glucocorticoid (budesonide) in dogs by high-performance liquid chromatography. J. Steroid. Bjochem. 1979; 10: 317.

21. Daemen M, Smits JFM, Ruers TJM, Van Dongen JJ, Thijssen $H$. Local drug administration: kinetic evaluation of local and systemic infusion of the high hepatic clearance substance propanolol in rat cardiac grafts. In: Daemen $\mathrm{M}$. Local drug administration; an experimental study on its possibilities and limitations. Thesis. Maastricht, The Netherlands: University of Limburg, 1987; 91.

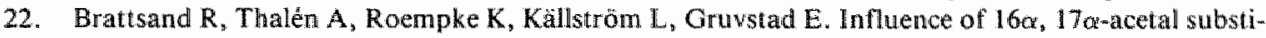
tution and steroid nucleus fluorination on the topical to systemic activity ratio of glucocorticoids. J. Steroid Biochem. 1982; 16: 779.

23. Dahlbäck M, Bergstrand $\mathrm{H}$, Brattsand R. Antigen induced bronchial analphylaxis in actively sensitized SD rats: effects of glucocorticoid treatment. Allergy 1986; $41: 210$.

24. Johansson SA, Andersson KE, Brattsand $R$, Gruwstad E, Hedruer P. Topical and systemic glucocorticoid potencies of budesonide and beclomethasone dipropionate in man. Eur. J. Clin. Pharmacol. 1982; 22: 523.

25. Clissold SP, Heel RC. Budesonide: a preliminary review of its pharmacodynamic properties and therapeutic efficacy in asthma and rhinitis. Drugs $1984 ; 28: 485$.

26. Dahlberg $\mathrm{E}$, Thalén $\mathrm{A}$, Brattsand $\mathrm{R}$, et al. Correlation between chemical structure, receptor binding and biological activity of some novel, highly active, $16 \alpha, 17 \alpha$-acetal substituted glucocorticoids. Mol. Pharmacol. 1984; 25: 70.

27. Häyry $\mathrm{P}$, von Willebrand $\mathrm{E}$, Soots A. In situ effector mechanisms in rat kidney allograft rejection.

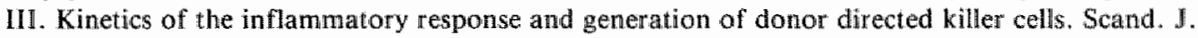
Immunol. 1979; 10: 95 .

28. Nathan CF, Kaplan G, Lewis WR, et al. Local and systemic effects of intradermal recombinant interferon- $\gamma$ in patients with lepromatous leprosy. N. Engl. J. Med. 1986; 315: 6.

29. Milton AD, Fabre JW. Massive induction of donortype class I and class II major histocompatibility complex antigens in rejecting cardiac allografts in the rat. J. Exp. Med. 1985; 161: 98.

30. Engleman EG, Benike CJ, Grumet FC, Evans RL. Activation of human T lymphocyte subsets: helper and suppressor/cytotoxic $T$ cells recognize and respond to distinct histocompatibility antigens. J. Immunol. 1981; 127: 2124 .

31. Miller JFAP, Vadas MA, Whitelaw A, Gamble $\mathbf{J}$, Role of major histocompatibility complex gene products in delayed-type hypersensitivity. Proc. Natl. Acad. Sci. USA 1976; 73: 2486.

32. Häyry $P$. Intragraft events in allograft destruction. Transplantation 1984; 38: 1 .

33. Arya SK, Wong-Staal F, Gallo RC. Dexamethasone-mediated unhibition of human T cell growth factor and $\gamma$-interferon messenger RNA. J. Immunol. 1984; 133:273.

34. Gillis $\mathrm{S}$, Crabtree GR, Smith KA. Glucocorticoid-induced inhibition of $\mathrm{T}$ cell growth factor production: I. The effect on mitogen-induced lymphocyte proliferation. J, Immunol. 1979; 123: 1624.

35. Orlowski M, Mizoguchi H, Wilk S. N-Acyl-y-glutamyl derivatives of sulfamethoxazole as models of kidney selective prodrugs. J. Pharmacol. Exp. Ther. 1980; 212; 167.

36. Smits JFM, Struyker-Boudier HAJ. Preferential renal vasodilator effects of CGP 22979A in conscious spontaneously hypertensive rats. $J$. Pharmacol. Exp. Ther. 1985; 232: 845 . 


\section{Study 7}

\section{The effect of steroids on the regulation of MHC-class II expression on human non-lymphoid tissue.}

Accepted for publication in Transplantation; in press 1989.

\section{Summary}

The induction of MHC-class II antigens on human non-Iymphoid tissues plays an essential role during the inhibition and augmentation of the immune response. Steroids have long been shown to possess strong immunosuppressive properties and successful steroid treatment has been associated with the absence of MHC-class II antigens on grafted tissues. In this study we more specifically investigated the effect of steroids on the regulation of MHC-class II expression on non-lymphoid tissue. First the influence of prednisolone on the induction process of MHC-class II antigens on non-lymphoid tissue was determined. For this purpose vascular endothelial cells, kidney epithelial cells, fibroblasts and a human colon tumor cell line were incubated with rIFN- $\gamma$ or primary MLC supernatant in the absence or presence of different concentrations of prednisolone. It was demonstrated that the induction process of MHC-class II antigens on these cell types was not affected by the drug at the different concentrations tested $(1,10$ and $100 \mu \mathrm{g} / \mathrm{ml})$.

Next, the effect of prednisolone on the production of MHC-class II inducing factors was investigated. The drug was added at initiation of culture to primary MLC and the MHC-class II inducing capacity of the supernatants was determined on day 7 . Prednisolone at concentrations of $0.5-100 \mu \mathrm{g} / \mathrm{ml}$ clearly inhibited the overall production of those factors responsible for MHC-class II induction on non-immunological cells. The drug inhibited the production of IFN- $\gamma$ as well as of non-IFN- $\gamma$ MHC-class II inducing mediators. At a concentration of $1 \mu \mathrm{g} / \mathrm{ml}$ the production of IFN- $\gamma$ and non-IFN- $\gamma$ MHC-class II inducing mediators was reduced by respectively $85 \%$ and $75 \%$. At a concentration of $10 \mu \mathrm{g} / \mathrm{ml}$ the production of both IFN- $\gamma$ and non-IFN- $\gamma$ mediators was almost completely inhibited. It is concluded that steroids downregulate the expression of MHC-class II antigens on non-lymphoid tissue by the inhibition of the production of MHC-class II inducing mediators. However, once these mediators are present, the induction process itself is not affected by the drug. 


\section{Introduction}

Glucocorticosteroids are widely used to inhibit the immune response in auto-immune disease and graft rejection. Several mechanisms have been proposed to explain the anti-inflammatory potency of the drug $(1,2)$. Results obtained in vivo emphasis the effect of glucocorticosteroids on the redistribution of leucocytes. More specific actions of the drug on immunoreactive cells were demonstrated in vitro. Glucocorticosteroids were shown to inhibit the production of mono- and lymphokines such as interleukin 1, interleukin 2 (IL2), interferon- $\gamma$ (IFN- $\gamma$ ) and tumor necrosis factor- $\alpha$ (TNF- $\alpha$ ) (3-7). On the other hand controversial results were reported regarding the effect of the drug on MHC-class II induction on immunoreactive cells, which is a prerequisite for lymphocyte-macrophage interaction during the induction of the immune response. For example the induction of MHC-class II antigens on mouse macrophages by lymphokines such as IFN- $\gamma$ was shown to be inhibited by the drug $(3,8)$. However diametrically opposed results were obtained with human monocytes. Steroids were reported to increase the density of MHC-class II antigens on human monocytes as well as to enhance the MHC-class II inducing effect of IFN- $\gamma$ on these cells $(9,10)$. This difference in results obtained in human monocytes compared to mouse macrophages have been ascribed to species difference possibly related to the difference in glucocorticosteroid sensitivity between mouse and man.

MHC-class II antigens, are not only expressed on the cell surface of immunoreactive cells. Also other cell types such as endothelial cells, fibroblasts and epithelial cells can express MHC-class II antigens (11-13). Moreover, it has been widely accepted that the induction of $\mathrm{MHC}$-class II antigens on these non-immunoreactive cells plays an essential role in the augmentation of the immune response during autoimmune disease and graft rejection (14-23). Recently it was demonstrated that the inhibition of MHC-class II induction on renal tubular cells was associated with the absence of graft destruction in rat renal allografts despite the presence of activated $T$ lymphocytes within the graft $(24,25)$. For most non-immunoreactive cells the expression of MHC-class II antigens is not a constitutive property but is in general related to inflammatory processes. Kidney tubular cells, heart cells, gut epithelium and epithelium of the skin, which are, with the exception of proximal tubular cells, all MHC-class II negative under normal conditions, express MHC-class II antigens during allograft rejection $(17-19,24,25)$, GVH disease (14-16) or local infections (26). Lymphokines, such as IFN- $\gamma$, are held responsible for the induction of MHCclass II antigens on these non-immunological cells (27-33).

Successful steroid therapy has been associated with the absence or reduction of MHC-class II expression on diseased tissue $(25,34)$. Although the effect of steroids on immunoreactive cells has thoroughly been studied, the mechanism by which steroids effect MHC-class II regulation on non-lymphoid tissue is still open to discussion. It is the purpose of this study to investigate more in detail the effect of glucocorticosteroids on the regulation of MHC-class II expression on these nonimmunological cells. 


\section{Materials and methods}

Cells. Human umbilical venous endothelial (HUVE) cells were isolated by selective collagenase digestion of the umbilical vein. The cells were cultured in fibronectincoated tissue culture flasks in RPMI 1640 (Gibco Europe, Paisley, Scotland), supplemented with $20 \%$ heat-inactivated human serum, $50 \mu \mathrm{g} / \mathrm{ml}$ heparin, endothelial cell growth supplement ( $30 \mu \mathrm{g} / \mathrm{ml}$; Collaborative Research, Lexington, MA) and antibiotics. Contamination with fibroblasts and smooth muscle cells was excluded by verification of purity with anti-Factor VIII monoclonal antibody, which reacts specifically with endothelial cells. Kidney epithelial cells were isolated from human kidneys by trypsinization. Kidney epithelial cells of three or four passages were used and verification of purity was performed by morphological appearance and staining with anti-keratin monoclonal antibodies specific for epithelial cells. Kidneys from different donors have been used, harvested by our own center, and for medical reasons were rejected for transplantation use. Human fibroblasts isolated from fetal lung tissue were kindly provided by Dr. Galama, Dept. of Virology, Academic Hospital Maastricht. Human large bowel adenocarcinoma cells COLO 205 were a gift of Dr. Verstijnen, Dept. of Pathology, University of Limburg, Maastricht. Fibroblasts, kidney epithelial cells and COLO 205 cells were cultured in RPMI 1640 supplemented with 10\% inactivated FCS and antibiotics.

Reagents. Prednisolone (Centrachemie, Etten-Leur, The Netherlands) was dissolved in pyrogen-free distilled water and diluted to clinically relevant concentrations in complete culture medium. Human cDNA derived rIFN- $\gamma$ was kindly provided by Dr. Devos, Ghent, Belgium. The monoclonal antibody anti-IFN- $\gamma$ (antibody D9D10) was a gift of Dr. de Ley, Laboratory of Biochemistry, University of Leuven, Belgium. The antibody inhibits the effect of both natural and rIFN- $\gamma$ in a virus protection assay (35). Primary mixed lymphocyte culture (MLC) supernatants were prepared as usual. Peripheral blood mononuclear cells were isolated from the buffy coats of healthy human blood donors (buffy coats were kindly provided by Bloed Bank Zuid-Limburg, Maastricht, The Netherlands) by density centrifugation on Lymphoprep (Nyegaard, Oslo, Norway). Bulk primary mixed lymphocyte cultures were established by co-culturing $10 \times 10^{6}$ responding lymphocytes with $5 \times 10^{6}$ irradiated $(4,000 \mathrm{rad}$.) stimulating lymphocytes in $10 \mathrm{ml}$ complete culture medium, which consisted of RPMI 1640, supplemented with $10 \%$ human serum, $100 \mathrm{IU} / \mathrm{ml}$ penicillline and $100 \mu \mathrm{g} / \mathrm{ml}$ streptomycin. Cultures were performed in $50 \mathrm{ml}$ flasks and incubated for 7 days in humified atmosphere at $37^{\circ} \mathrm{C}$ in air containing $7.5 \% \mathrm{CO} 2$. On day 7 supernatants were harvested, centrifuged to remove cells and filtered through a $0.22 \mu \mathrm{m}$ sterile Millex-GV filter unit (Millipore, Molsheim, France). At the same time cells were pulsed with ${ }^{3} \mathrm{H}-\mathrm{TdR}$ for $4 \mathrm{hr}$ and subsequently collected with a microharvester, ${ }^{3} \mathrm{H}-\mathrm{TdR}$ uptake was assayed by liquid scintillation. ${ }^{3} \mathrm{H}-\mathrm{Td} \mathrm{R}$ uptake in control cultures ( $100 \%$ response) ranged from $10.000 \mathrm{cpm}$ to $35.000 \mathrm{cpm}$. Prednisolone added to the cultures at a concentration of $0.5 \mu \mathrm{g} / \mathrm{ml}$ reduced cellular 
proliferation to $50 \%$, at higher concentrations inhibition of cellular proliferation increased and at a dose of $10 \mu \mathrm{g} / \mathrm{ml}$ proliferative response was reduced to $20 \%$.

\section{Induction and detection of MHC-class II antigens on HUVE cells, kidney epithelial} cells, fibroblasts and COLO 205 cells. HUVE cells, kidney epithelial cells, fibroblasts and COLO 205 cells were incubated for respectively $2,5,5$, and 3 days with cult ture medium supplemented with rIFN- $\gamma$ or MLC supernatant. During the experiments with HUVE cells and COLO 205 cells rIFN- $\gamma$ was used at a concentration of 100 units $/ \mathrm{ml}$, during the experiments with kidney epithelial cells and fibroblasts rIFN- $\gamma$ was used at concentrations of, respectively, 200 units $/ \mathrm{ml}$ and 500 units $/ \mathrm{ml}$. After the incubation period the induction of MHC-class II antigens was studied with an indirect immunofluorescence technique. Cells were washed in phosphate buffered saline (PBS) $+0.1 \%$ bovine serum albumin $+0.01 \%$ sodium azide and incubated for half an hour at $4^{\circ} \mathrm{C}$ with the monoclonal antibody 7.5 .10 .1 , broadly reacting with MHC-class II antigens (36). After three further washes cells were incubated with fluorescein isothiocyanate-conjugated rabbit Ig anti-mouse Ig for 30 minutes at $4^{\circ} \mathrm{C}$. Cells were washed again and examined on FACS IV (Becton Dickinson, Sunnyvale, CA). Data are expressed in percentage MHC-class II positive cells.

\section{Assay to quantify MHC-class II inducing capacity of MLC culture supernatants.} MHC-class II inducing capacity of MLC culture supernatants was determined by incubation of test supernatants with human large bowel adenocarcinoma cells COLO 205. Twofold serial dilutions of the test supernatants were added to cluster wells containing $5 \times 10^{5}$ COLO 205 cells incubated in $0.5 \mathrm{ml}$ medium. Cultures were kept under standard conditions for 3 days. On this day cells were harvested and examined for membrane expression of MHC-class II antigens by indirect immunofluorescence. Results are quantified by probit analysis of relations of the obtained percentage of positive cells and the log of the dilution of supernatant to be tested and are expressed in arbitrary units. The lower limit of detection was equal to the MHCclass II expression induced by 2 IU/mI IFN- $\gamma$.

To determine more precisely the factors responsible for MHC-class II induction in MLC supernatants distinction was made between IFN- $\gamma$ and non-IFN- $\gamma$ MHC-class II inducing potency. The MHC-class II inducing capacity of factors others than IFN $-\gamma$ was studied, either by passing test supernatants, before incubation with COLO 205 cells, over a column coated with monoclonal anti-IFN- $\gamma$ or by incubating test supernatants with monoclonal anti-IFN- $\gamma$. In the latter case, test supernatants were first incubated for $1 \mathrm{hr}$ with monoclonal anti-IFN- $\gamma$ present in excess and subsequently added to COLO 205 cells as described. After supernatants were treated in either of both ways with anti-IFN- $\gamma$, IFN- $\gamma$ was completely removed from the supernatant as demonstrated in radioimmunoassay; IFN- $\gamma$ concentrations of these supernatants, determined in radioimmunoassay, were consistently below detection level. 
Determination of IFN- $\gamma$. IFN- $\gamma$ concentrations in supernatants were determined in a solid phase radioimmunoassay (Centocor, Malvern, PA). IFN- $\gamma$ concentration is expressed as International Units (IU) per ml. A unit refers to the NIH reference unit for interferon- $\gamma$.

\section{Results}

The effect of prednisolone on the process of induction of MHC-class II antigens on non-immunological cells. Prednisolone was tested for its ability to affect the action of MHC-class II inducing factors on non-immunological cells. The effect on the induction of MHC-class II antigens on four human cell types was studied; HUVE cells, kidney epithelial cells, fibroblasts and human adenocarcinoma cells (COLO 205). These cell types are known to express MHC-class II antigens after incubation with IFN- $\gamma$ or primary MLC supternatant $(28,29,35)$.

Indicated cell types were incubated with rIFN- $\gamma$ either in the presence or absence of prednisolone and after the incubation period MHC-class II expression was determined by immunofluorescence. As shown in Table $1, \operatorname{rIFN}-\gamma$ was able to induce MHC-class II expression on all the cell types tested. The percentage of positive cells ranged from $26 \%$ tot $85 \%$ for the different experiments. The addition of prednisolone in graded quantities of 1,10 and $100 \mu \mathrm{g} / \mathrm{ml}$ final culture concentration did not have a significant effect on the MHC-class II inducing capacity of rIFN- $\gamma$ in all cell types tested. Even at a concentration of $100 \mu \mathrm{g} / \mathrm{ml}$ prednisolone, no remarkable difference was observed on the induction of MHC-class II antigens between the cells incubated with or without the drug. It should be noticed that also prednisolone by itself did not affect the expression of MHC-class II antigens; MHC-class II expression on cells incubated with prednisolone alone was comparable to the MHC-class II expression in controls.

It has been demonstrated that besides IFN- $\gamma$ also non-IFN- $\gamma$ mediators are potent inducers of MHC-class II expression. Primary MLC supernatants were demonstrated to contain both IFN- $\gamma$ as well as MHC-class II inducing mediators different from IFN- $\gamma$ (35). In addition, we studied the effect of prednisolone on the overall MHCclass II inducing potency of primary MLC supernatants and more specifically on the MHC-class II inducing potency of non-IFN- $\gamma$ mediators. First, primary MLC supernatants were added to COLO 205 cells in the presence or absence of prednisolone. As shown in Table 2, prednisolone did not affect the induction of MHC-class II antigens by primary MLC supernatants. The percentage of positive cells was comparable with or without prednisolone present during the incubation period; about $85 \%$ of the cells became positive in the absence of prednisolone, while about $90 \%$ of the cells became positive when incubated in the presence of $100 \mu \mathrm{g} / \mathrm{ml}$ prednisolone. Next, the effect of prednisolone on the action of non-IFN- $\gamma$ mediators was tested. For this purpose supernatants were depleted of IFN- $\gamma$ before incubation with COLO 205 cells, either by addition of anti-IFN- $\gamma$ in excess or by passing the supernatants 
TABLE 1. The effect of prednisolone on the induction of MHC-class II antigens by rIFN- $\gamma$.

\begin{tabular}{|c|c|c|c|c|c|c|c|c|c|}
\hline \multirow{2}{*}{$\begin{array}{l}\text { TIFN-Y } \\
-\end{array}$} & \multirow{2}{*}{$\begin{array}{l}\text { predni- } \\
\text { solone } \\
\mu \mathrm{g} / \mathrm{ml}\end{array}$} & \multicolumn{2}{|c|}{$\begin{array}{l}\text { vascular } \\
\text { endothelial } \\
\text { cells }\end{array}$} & \multicolumn{2}{|c|}{$\begin{array}{l}\text { fibro- } \\
\text { blasts }\end{array}$} & \multicolumn{2}{|c|}{$\begin{array}{l}\text { kidney } \\
\text { epithelial } \\
\text { cells }\end{array}$} & \multicolumn{2}{|c|}{$\begin{array}{l}\text { COLO } \\
205 \\
\text { cells }\end{array}$} \\
\hline & & $3^{\text {a }}$ & 2 & 1 & 2 & 1 & 2 & 3 & 2 \\
\hline+ & - & 41 & 49 & 84 & 26 & 56 & 64 & 83 & 85 \\
\hline+ & 1 & 63 & 49 & 82 & 33 & 59 & 59 & 88 & 86 \\
\hline+ & 10 & 61 & 36 & 71 & 29 & 60 & 63 & 87 & 85 \\
\hline+ & 100 & 69 & 44 & 80 & 40 & 66 & 67 & 91 & 87 \\
\hline$=$ & 1 & 2 & 1 & 0 & 3 & 1 & 1 & 3 & 1 \\
\hline- & 10 & 4 & 3 & 1 & 5 & 2 & 1 & 4 & 2 \\
\hline- & 100 & 4 & 4 & 0 & 2 & 3 & 5 & 2 & $\overline{0}$ \\
\hline
\end{tabular}

Cells were incubated with or without rIFN- $\gamma$ as described in Materials and Methods. Incubalions were performed in the absence or presence of different concentrations prednisolone. After the incubation period MHC-class II antigen expression was determined. The resul's of 2 representative experiments are shown.

a Data are expressed in percentage MHC-class II positive cells.

TABLE 2. The effect of prednisolone on the induction of MHC-class II antigens by MLC supernatants and non-IFN- $\gamma$ mediators.

\begin{tabular}{|c|c|c|c|c|c|}
\hline \multirow{2}{*}{$\begin{array}{l}\text { COLO } 205 \\
\text { cells } \\
+\end{array}$} & \multirow{2}{*}{$\begin{array}{l}\text { prednisolone } \\
\mu \mathrm{g} / \mathrm{ml}\end{array}$} & \multicolumn{2}{|c|}{$\begin{array}{l}\text { primary MLC } \\
\text { supernatant }\end{array}$} & \multicolumn{2}{|c|}{$\begin{array}{l}\text { non-IFN- } \\
\text { mediators }\end{array}$} \\
\hline & & $82^{b}$ & 88 & 63 & 41 \\
\hline+ & 1 & 82 & 93 & 66 & 48 \\
\hline+ & 10 & 89 & 82 & 66 & 43 \\
\hline 4 & 100 & 87 & 92 & 73 & 48 \\
\hline
\end{tabular}

COLO 205 cells were incubated in the absence or presence of prednisolone with a) primary $M L C$ supernatants and b) non-IFN- $\gamma$ MHC-class II inducing mediators. To study the effect of prednisolone on the action of MHC-class II inducing mediators others than IFN- $\gamma$,

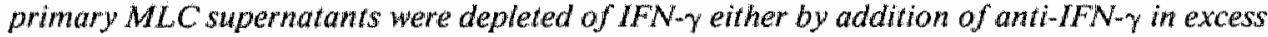
or by passing the supernatants, before incubation with COLO 205 cells, over a column coated

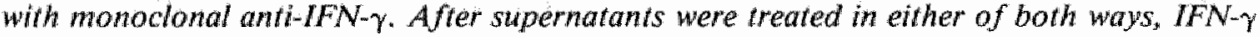
was completely removed from the supernatant as demonstrated in radioimmunoassay. The results of 2 representative experiments are shown.

"IFN- $\gamma$ titers of supernatants ranged from $25-45 \mathrm{IU} / \mathrm{m}$.

"Data are expressed in percentage MHC-class II positive cells.

over a column coated with anti-IFN- $\gamma$. Supernatants treated this way showed a reduced but still strong potency to induce MHC-class II antigens (Table 2). Similar to the results obtained with rIFN- $\gamma$ and MLC supernatants, prednisolone did not affect the MHC-class II inducing potency of the non-IFN- $\gamma$ mediators. Superma- 


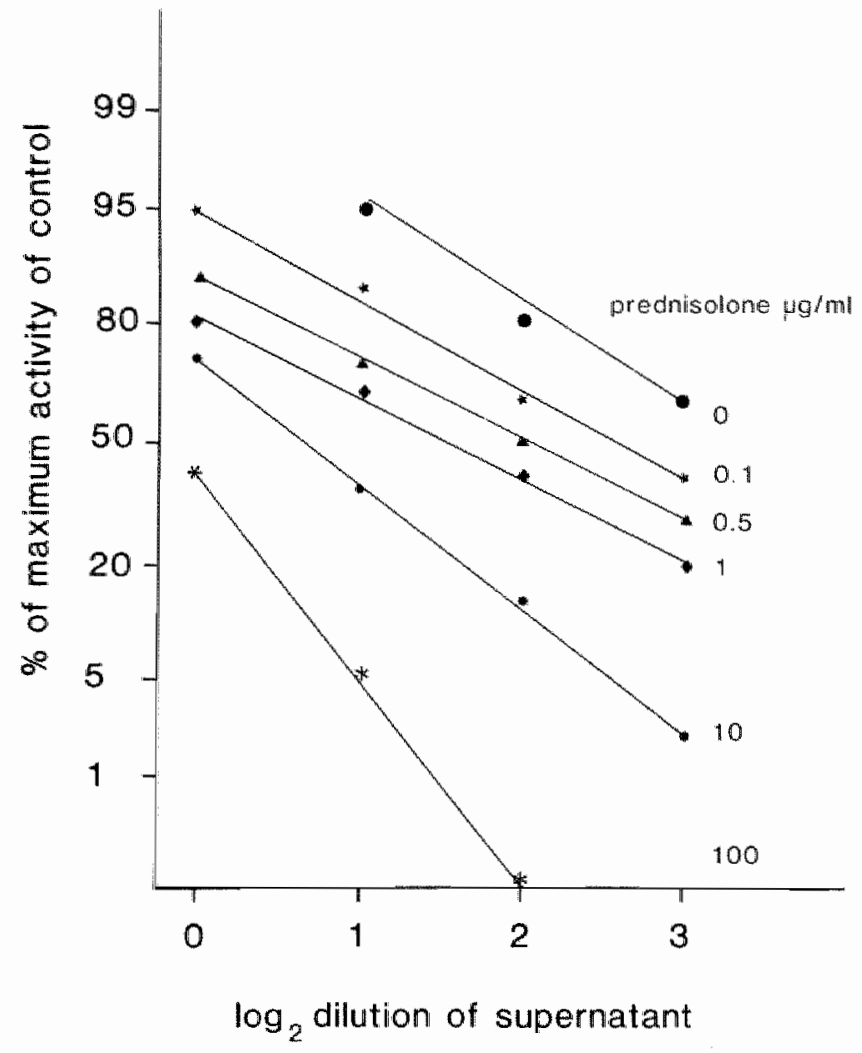

Figure IA

FIGURE 1. Effect of prednisolone on the overall production of MHC-class II inducing factors in primary $M L C$. Primary $M L C$ were peformed in the absence or presence of different concentrations prednisolone. After 7 days supernatants were harvested to determine $M H C$ class II inducing capacity. Serial dilutions of supernatants were incubated for 3 days with COLO 205 cells. On day 3, MHC-class II expression on COLO 205 cells was determined by immunofluorescence.

FIGURE $1 A$ shows the MHC-class II inducing capacity of the supernatants quantified by probit analysis of relations of the obtained percentage of positive cells and the log of the dilution of supernatant to be tested. A representative experiment from a series of three is given.

tants depleted of IFN- $\gamma$ induced a comparable percentage of MHC-class II positive cells with or without prednisolone present during the incubation period.

From the data obtained thusfar it can be concluded that prednisolone does not directly affect the induction process of MHC-class II antigens on non-immunological cells. 


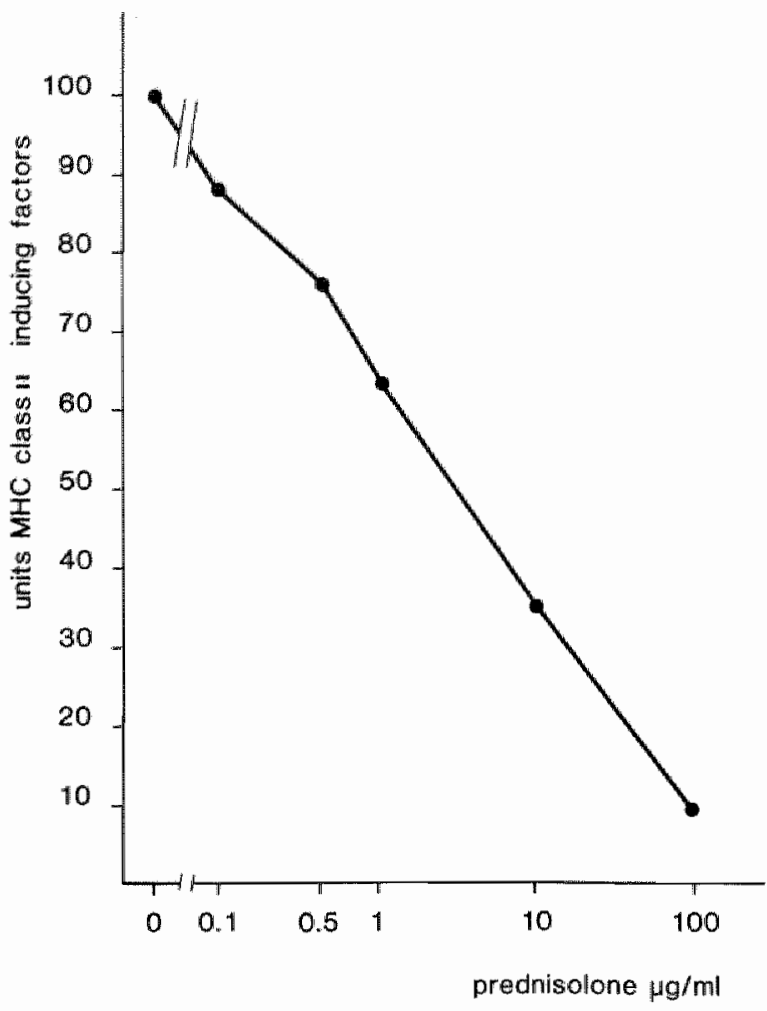

Figure IB

FIGURE IB shows the units MHC-class II inducing factors per ml present in the different supernatants when the amount of $M H C$-class $I I$ inducing factors in control supernatant is arbitrarily defined 100 units $/ \mathrm{ml}$.

The effect of prednisolone on the overall production of MHC-class II inducing factors. In addition, experiments were performed to investigate the effect of prednisolone on the owerall production of those mediators responsible for the induction of MHC-class II antigens on non-immunological cells. Various concentrations of prednisolone were added to primary bulk MLC at the initiation of culture and after 7 days MHC-class II inducing capacity of the supernatants was determined. Figure IA shows the MHC-class II inducing capacity of serial dilutions of supernatants harvested from primary MLC, cultured in the absence or the presence of several concentrations of prednisolone. Supernatants harvested from controll primary MLC cultures possessed strong MHC-class II inducing capacities; supernatants however from cells, cultured in the presence of prednisolone, showed a substantial reduction in MHC-class II inducing capacity. Since it was demonstrated that prednisolone did not affect the induction process of MHC-class II antigens (Table 1 and 2), these data indicate that the production of MHC-class II inducing factors is inhibited by the 


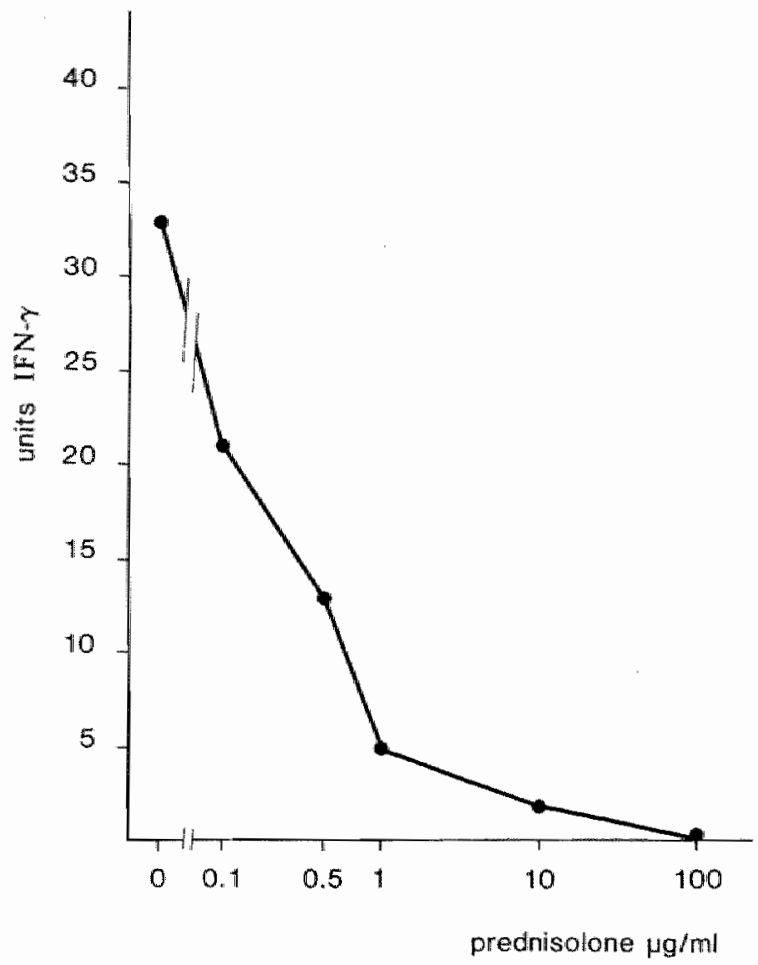

Figure 2

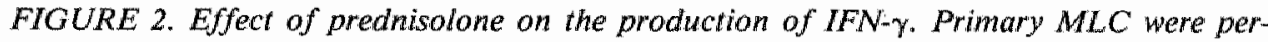
formed in the absence or presence of several concentrations prednisolone. On day 7 superna. tants were collected and IF $N$ - $\gamma$ content was determined by radiaimmunoassay. All titers are expressed in terms of a reference standard and are given in $1 \mathrm{U} / \mathrm{ml}$. A representative experiment from a series of three is given.

drug. The magnitude of this inhibition can be calculated from data shown in figure 1A. When the amount of MHC-class II inducing factors in control supernatant is arbitrarily defined 100 units $/ \mathrm{ml}$, the amount of $\mathrm{MHC}$-class II inducing factors in other supernatants can be quantified. Figure IB shows the units of MHC-class II inducing factors produced in primary $\mathrm{MLC}$ in the presence of different concentrations of prednisolone. Significant inhibition of the overall production of MHC-class II inducing factors is observed with increasing concentrations of prednisolone. Since IFN- $\gamma$ and non-IFN- $\gamma$ MHC-class II inducing mediators are present in primary MLC supernatant additional experiments were performed tot investigate whether the production of IFN- $\gamma$ as well as the production of non-IFN- $\gamma$ MHC-class II inducing mediators was inhibited by prednisolone.

The effect of prednisolone on the production of IFN- $\gamma$. Day 7 primary MLC supernatants, cultured with or without prednisolone, were analyzed for the presence 


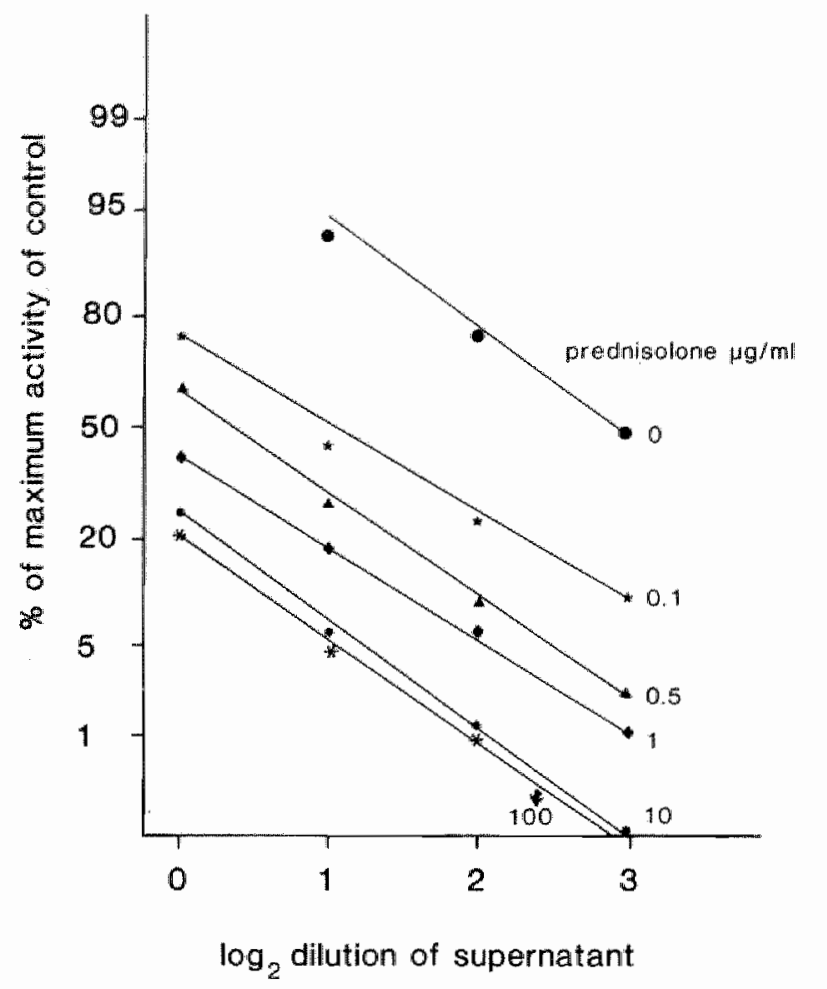

Figure $3 A$

FIGURE 3. Effect of predmisolone on the production of non-IFN- $\gamma$ MHC-class II inducing mediators. Primary $M L C$ were performed in the absence or presence of different concentrations prednisolone. After 7 days supernatants were harvested to determine non-IFN- $\gamma M H C$ class II inducing capacity. The MHC-class $I I$ inducing capacity of factors others than IFN- $\gamma$ was studied by depleting the supernatants of IFN- $\gamma$. For this purpose test supernatants were passed over a column coated with anti-IFN- $\gamma$. Supernatants treated this way were added to COLO 205 cells and allowed to incubate for 3 days. On day 3, MHC-class II expression on COLO 205 cells was determined by immunoflworescence.

FIGURE 3 A shows the non-IFN- $\gamma$ MHC-class II inducing capacity of the supernatants quantified by probit analysis of relations of the obtained percentage of positive cells and the log of the dilution of supernatant to be tested. A representative experiment from a series of three is given.

of IFN- $\gamma$. IFN- $\gamma$ titers were determined in a solid phase radioimmunoassay and expressed as IU/ml. Results given in figure 2 demonstrate that prednisolone clearly inhibits the production of IFN- $\gamma$ in primary MLC. IFN- $\gamma$ titers within the supernatants gradually decreased with increasing concentrations of prednisolone present during primary MLC. At a concentration of $10 \mu \mathrm{g} / \mathrm{ml}$ prednisolone, IFN- $\gamma$ could hardly be demonstrated.

The effect of prednisolone on the production of non-IFN- $\gamma$ mediators. To explore the effect of prednisolone on the production of MHC-class II inducing agents others 


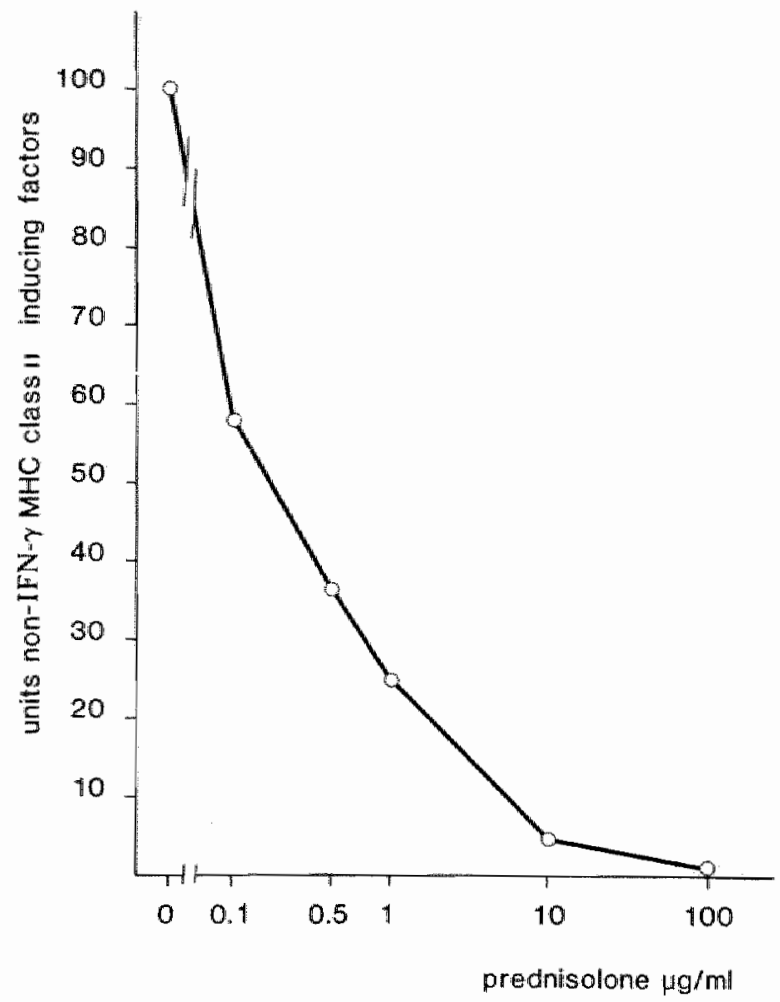

Figure $3 B$

FIGURE $3 B$ shows the units non-IFN- $\gamma$ MHC-class II inducing factors per ml present in the different supernatants when the amount of non-IFN- $\gamma$ MHC-class II inducing factors in control supernatant is arbitrarily defined 100 units $/ \mathrm{ml}$.

than IFN- $\gamma$, day 7 primary MLC supernatants made in the presence or absence of prednisolone, were incubated with anti-IFN- $\gamma$ in excess or passed over a column coated with anti-IFN- $\gamma$ as described. Figure 3A shows the MHC-class II inducing capacity of serial dilutions of primary MLC supernatants treated this way. A clear reduction in MHC-class II inducing capacity is seen with increasing concentrations of prednisolone. Since we demonstrated that prednisolone did not affect the induction process of MHC-class II antigens by non-IFN- $\gamma$ mediators (Table 2), the data indicate that prednisolone inhibits the production of these non-IFN- $\gamma$ mediators. The units of non-IFN- $\gamma$ MHC-class II inducing mediators produced in primary MLC, in the absence or presence of several concentrations of prednisolone, are illustrated in figure 3B. It is demonstrated that the production of these mediators is as sensitive to prednisolone as the production of IFN- $\gamma$. It should be noticed that at a concentration of $10 \mu \mathrm{g} / \mathrm{ml}$, prednisolone inhibits almost completely the production of IFN- $\gamma$ as well as of non-IFN- $\gamma$ MHC-class II inducing mediators. However, as demonstrated in figure $1 \mathrm{~B}$, the overall MHC-class II inducing capacity of the supernatants is decreased by $65 \%$ at this concentration. The sight difference between 
these values can be explained by the fact that combined action of IFN- $\gamma$ and nonIFN- $\gamma$ mediators results in a marked potentiation of the MHC-class 11 inducing effect, as reported earlier (35).

\section{Discussion}

MHC-class II antigens are variably expressed on immunological cells as well as on non-immunological cells. The induction of MHC-class II antigens on both cell types is of potential importance to both the initiation as well as the effector phase of the immune response. Glucocorticosteroids have long been known to posses a potent inhibitory effect on cellular immune response $(1,2)$. In this regard the effect of steroids on the expression of MHC-class II antigens on immunoreactive cells has extensively been studied $(3,8-10,37)$.

In contrast however, less is known about the effect of steroids on the regulation of MHC-class II antigens on non-immunoreactive cells. Häyry et al. reported first that steroids administered to rats downregulate MHC-class II antigen presentation on rat tissue (33). The authors suggested that this phenomenon was most likely an indirect effect of the drug. Moreover, in vitro, the expression of MHC-class II antigens on human renal tubular cells was not affected by the drug (29). These results prompted us to study more specifically the effect of steroids on the regulation of MHC-class II antigen expression on non-immunological cells. For this purpose the effect of prednisolone on the induction of MHC-class II antigens on several human tissue cell types was tested. It was observed that prednisolone had neither a direct effect on the induction of the MHC-class II antigens on non-immunological cells nor on the basal expression of these antigens on those cells. However, when prednisolone was added to primary MLC cultures and the supernatants were subsequently tested for the ability to induce MHC-class II antigens, MHC-class II inducing capacity of the supernatants made in the presence of prednisolone was significantly reduced compared with the control supermatants. Prednisolone inhibited the overall production of MHC-class II inducing factors. More specifically it was demonstrated that IFN- $\gamma$ as well as non-IFN- $\gamma$ MHC-class II inducing mediators were clearly inhibited by the drug. In conclusion, our results demonstrate that in regard to MHC-class II antigen regulation on non-immunological cells steroid mediated immunosuppression occurs at the level of Jymphokine production. This finding is in agreement to the observations made concerning the anti-proliferative effect of steroids. Since it was demonstrated that steroids inhibited cell proliferation mainly by the inhibition of IL2 production, while cell activation or cell viability were not primarily affected by the drug $(5,6)$. Both observations are in concordance to Arya, who showed that dexamethasone inhibited the induction of both IL2 and IFN-y MRNA in enriched T Iymphocytes stimulated with PHA (4).

Which other mediators, besides IFN- $\gamma$, are meanwhile involved in the induction of MHC-class II antigens on human non-immunological cells, and are apparently in- 
hibited by prednisolone in primary MLC, is not well established yet. A human mediator, present in primary MLC supernatant, different from IFN- $\gamma$ with a molecular weight of $32 \mathrm{kD}$ was reported earlier (35). Moreover, an enhancing effect of TNF- $\alpha$ on MHC-class II induction was described for a murine macrophage cell line, some human tumor cell lines and activated human $T$ cells (38-40). Recently we observed that TNF- $\alpha$ causes also a significant enhancement of IFN- $\gamma$ induced MHC-class III expression on HUVE cells when added after the addition of IFN $\gamma$ (41).

During in vivo studies with rodents, Unanue and Häyry $(3,33)$ both demonstrated a strong antagonistic effect of glucocorticosteroids on the induction of MHC-class II antigens on murine macrophages and rat tissue cells in response to respectively lymphokines and IFN- $\gamma$. In these experiments TNF- $\alpha$, which is produced in response to IFN- $\gamma$, enhances the response to IFN- $\gamma$ itself (42). Steroids inhibit the production of TNF- $\alpha$ (7), thus preventing the enhancement of MHC-class II antigens by TNF- $\alpha$, which may explain the antagonistic effect of steroids on IFN- $\gamma$ or lymphokine induced MHC-class II expression in vivo.

The finding that prednisolone has no direct effect on the induction of MHC-class II antigens nor on the basal expression of these antigens on non-immunological cells is in contrast to observations made with human monocytes, which showed an increased expression of MHC-class II antigens after incubation with steroids $(9,10)$. However, the regulation of MHC-class II expression on non-immunological cells cannot be compared with the regulation of $\mathrm{MHC}$-class II antigens on immunoreactive cells, on which MHC-class II antigens are also induced by the cell activation process itself.

Evidence that steroids in vivo inhibit the production of IFN- $\gamma$ was provided by Dupont et al. (43). They reported that IFN- $\gamma$ production in renal transplant patients and human volunteers, treated with steroids, was markedly reduced. Prednisolone concentrations from 0.1 to $10 \mu \mathrm{g} / \mathrm{ml}$, used in our experiments, are comparable to drug levels reached in vivo. In various diseases prednisolone dosages from $10 \mathrm{mg}$ to $100 \mathrm{mg}$ per day are given, which results in drug levels between 0.1 and $1 \mu \mathrm{g} / \mathrm{ml}$ $(44,45)$. During rejection episodes of allografts even higher dosages of steroids are given and in these states as well as during local application of the drug, prednisolone levels are up to $10 \mu \mathrm{g} / \mathrm{ml}$ or higher.

Although steroid treatment in renal transplant patients has been associated with the absence of MHC-class II antigens on grafted tissue (34), the mechanism by which steroids interfered with MHC-class II expression on non-lymphoid tissue was still open to discussion. Our results show that this phenomenon has to be explained by the effect of the drugs on the production of MHC-class II inducing factors while a direct effect of steroids on the grafted tissue is most unlikely. This observation may be helpful in the further understanding of the immunosuppressive effect of steroids in graft rejection.

Acknowledgments. This work was supported by the Dr. Saal van Zwanenbergstichting and the Dutch Kidney Foundation (Nederlandse Nierstichting; C85.519). 
We thank Prof. Dr. M. de Ley, University of Leuven, Belgium, for providing D9D10 anti-IFN- $\gamma$ monoclonal antibody and Mrs. C.M.P. Spronck for excellent secretarial assistance.

Abbreviations used in this paper: HUVE, human umbilical venous endothelial cells; IFN- $\gamma$, interferon-gamma; IL2, Interleukin 2; MLC, mixed lymphocyte culture; TNF- $\alpha$, tumor necrosis factor- $\alpha$.

\section{References}

1. Cupps TR, Fauci AS. Corticosteroid-mediated immunoregulation in man. Immunological Rev. 1982; 65: 133.

2. Dupont $\mathbf{E}$, Wybran $\mathrm{J}_{2}$ Toussaint $\mathrm{C}$. Glucocorticosteroids and organ transplantation. Transplantation 1984; $37: 331$.

3. Sinyder DS, Unanue ER. Corticosteroids inhibit murine macrophage la expression and Interleukin I production. J. Immunol. 1982; 129: 1803.

4. Arya $\mathrm{SK}$, Wong-Staal $\mathrm{F}$, Gallo $\mathrm{RC}$. Dexamethasone-mediated inhibition of human $\mathrm{T}$ cell growth factor and $\gamma$-interferon messenger RNA. J. Immunol. 1984; 133: 273.

5. Larsson EL. Cyclosporin $\mathrm{A}$ and dexamethasone suppress $\mathrm{T}$ cell responses by selectively acting at distinct sites of the triggering process. J. Immunol. 1980; 124; 2828.

6. Gillis $S$, Crabtree $G R$, Smith KA. Glucocorticoid-induced inhibition of $T$ cell growth factor production. I. The effect on mitogen induced lymphocyte proliferation. I. Immunol. 1979; 123: 1624 .

7. Waage A, Bakke O. Glucocorticoids suppress the production of tumor necrosis factor by lipopolysaccharide-stimulated human monocytes. Immunology 1988; 63: 299.

8. Warren MK, Vogel SN. Opposing effects of glucocorticosteroids on interferon- $\gamma$ induced murine macrophage Fc receptor and la antigen expression. J. Immunol. 1985; 134: 2462.

9. Gerrard TL, Cupps TR, Jurgensen CH, Fauci AS. Increased expression of HLA-DR antigens in hydrocortisone-treated monocytes. Cell. Immunol. 1984; 84: 311.

10. Shen L, Guyre PM, Ball ED, Fanger MW. Glucocorticoids synergise with recombinant gammainterferon in augmenting class I and class II HLA antigen expression on human monocytes. Fed. Proc. 1984: 43: 1689.

11. Wiman $K$, Kurman $B$, Forsum $U$, Klareskog $L$, Malmmäs-Tjernland $U$, Rask $L$, Trägărdh $L$,Peterson PA. Occurence of lat antigens on tissues of nonlymphoid origin. Nature 1978; $276: 711$.

12. Frelinger IA Tissue distribution and cellular expression of la antigens. In: Ia antigens wol. I.S. Ferrone and C. David eds. C.R.C. Press Florida, p. 37.53, 1982.

13. Natali $P G$, Ruso $C$, Kau $N y$. et al. Tissue distribution of human la like antigens. In: Ia antigens vol. II, S. Ferrone and C. David eds. C.R.C. Press. Florida p. 81-109, 1982.

14. Lampert IA, Suitters AI, Chisholm PM. Expression of la antigens on epidermal keratinocytes in graft-versus-thost disease. Nature 1981; 293: 149.

15. Mason DW, Dallman M, Barclay AN. Graft versus host disease induces expression of la antigen in rat epidermal cells and gut epithelium. Nature 1981; 293: 150.

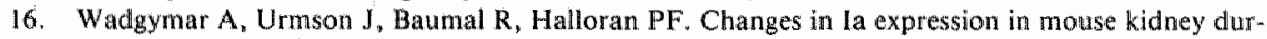
ing acute graft versus host disease. J. Immunol. 1984; 132: 1826.

17. Milton AD, Fabre JW. Massive induction of donor-type class I and class II major histocompatibili$1 y$ complex antigens in rejecting cardiac allografts in the rat. J. Exp. Med. 1985; 161:98.

18. Hall BM, Bishop GA, Duggin GG, Horwath IS, Philips I, Tiller DJ. Increased expression of HLADR antigens on renal tubular cells in renal transplants: relevance to the rejection response. Lancet $1984 ; 2: 247$. 
19. de Waal RMW, Bogman MJJ, Maass CN, Conelissen IMH, Tax WJM, Koene RAP. Variable expression of Ia antigens on vascular endothelium of monse skin allografts. Nature 1983; 303:426.

20. Sobel RA, Blanchette BW, Bhan HK, Calvin RB. The immunopathology of experimental allergic encephalomyelitis. II. Endothelial cell la increases prior to inflammatory cell infiltration. J. Immunol. 1984; 132: 2402.

21. Ballardini G, Bianchi FB, Doniach D, Mirakian R, Pisi E, Bottazzo GF. Aberrant expression of HLA-Dr antigens on bileduct epithelium in primary biliary cirrhosis; relevance to pathogenesis. Lancet 1984; 3: 1009.

22. Handfusa T, Pujol-Borrel R, Chivato L, Russel RCG, Doniach D, Bottazzo GF. Aberrant expression of HLA-Dr antigen on thyrocytes in Grave's disease: relevance for autoimmunity. Lancet 1983; 2: 1111 .

23. Lindahl G, Hedfors E, Klareskog L, Forsum U. Epithelial HLA-Dr expression and T lymphocyte subsets in salivary glands in Sjörgen's syndrome. Clin. Exp. Immunol. 1985; 61: 475.

24. Ruers TJM, Buurman WA, Van der Linden $\mathrm{CJ}$, Kootstra $\mathrm{G}$. Local inhibition of MHC-class II induction within the graft; an effective way to induce immunosuppression. Transplant. Proc. 1987; XIX: ע: 246.

25. Ruers TJM, Buurman WA, Van Boxtell CJ, Van der Linden CJ, Kootstra G. Immunohistological observations in rat kidney allografts following local steroid administration. 5 . Exp. Med. 1987; 166: 1205.

26. Barclay AN, Mason DW. Induction of Ia antigens in rat epidermal cell and gut epithelium by immunological stimuli. J. Exp. Med. 1982; 156: 1665.

27. Pober JS, Collins T, Gimbrone MA, Cotran RS, Gitlin JD, Fiers W, Clayberger C, Krensky AM, Burakoff SJ, Reiss CS. Lymphocytes, recognize human vascular endothelial and dermal fibroblasts. la antigens induced by recombinant immune interferon. Nature 1983; 305: 726.

28. Pober JS, Gimbrone MA, Cotran RS, Reiss CS, Burakoff SJ, Fiers WA, Ault KA. Ia expression by vascular endothelium is inducible by activated $T$ cells and by human gamna interferon. J. Exp. Med. 1983; 157: 1339.

29. Bishop GA, Hall BM, Suranyi MG, Tiller DJ, Horvath JS, Duggin GG. Expression of HLA antigens on remal tubular cells in culture. 1. Evidence that mixedl lymphocyte culture supernatants and gamma interferon increase both class $\mathbb{I}$ and class II HLA antigens. Transplantation 1986; 42: 671.

30. Basham TY, Merigan TC. Recombinant interferon- $\gamma$ increases HLA-DR synthesis and expression. J. Immunol. 1983; 130:1492.

31. Pfizenmaier K, Bartsch H, Scheurich P, Seliger B, Ucer U, Velmmeyer K, Nagel GA. Differential $\gamma$-interferon response of human colon carcinoma cells: inhibition of proliferation and modulation of immunogenicity as independent effects of $\gamma$-interferon on tumor cell growth. Cancer Res. 1985; 45: 3503 .

32. Nathan CF, Kaplan G, Levis WR et al. Local and systemic effects of intradermal recombinant interferon- $\gamma$ in patients with lepromatous leprosy. N. Engl. J. Med. 1986; 315: 6.

33. Leszezynski D, Ferry B, Schellekens H., v.d. Meide PH, Häyry P. Antagonistic effects on $\gamma$ interferon and steroids on tissue antigenicity. J. Exp. Med. 1986; 164: 1470.

34. Häyry $P$, von Willebrand $E$. The influence of the pattern of inflammation and administration of steroids on class II MHC antigen expression in renal transplants. Transplantation 1986; $42: 358$.

35. Groenewegen $G$, de Ley M, Jeunhomme GMAA, Butuman WA. Supernatants of thuman feucocyles contain a mediator, different from interfer on- $y$ which induces expression of MHC-class II an. tigens. J. Exp. Med. 1986; 164: 131.

36. Koning F, Schreuder J, Giphar M, Bruning H. A mouse monoclonal antibody detecting a DR related MT2-like specificity. Serology and Biochemistry. Hum. Immunol. $1984 ; 9: 221$.

37. Madsen M, Kissmeyer-Nielsen F, Rasmussen P. Andersen P. Decreased expression of HLA-DR antigens on peripheral blood B lymphocytes during glucocorticoid treatment. Tissue Antigens 1981 ; 17: 195 .

38. Chang R, He Lee S. Effects of interferon- $\gamma$ and tumor necrosis factor $\omega$ on the expression of an lla antigen on at murine macrophage cell line. J. Immunol. 1986; 137: 2853.

39. Pfizenmaier $K$, Scheurich $P$, Schlüter $C$, Krönke $M$. Tumor necrosis factor enhances Hil.A-A, $\mathbb{B}$, C and HLA-DR gene expression in human tumor cells. J. Immumol. 1987; 138: 975.

40. Scheurich $\mathbf{P}$, Thoma $\mathrm{B}$, Uecer $\mathrm{U}$, Pfizenmaier $\mathrm{K}$. Immunoregulatory activity of recombinant human tumor necrosis factor (TNF)-cx: induction of TNF receptors on human T cells and TNF $-\alpha *$ mediated erihancement of T cell responses. J. Immunol. 1987; 138: 1786. 
41. Leew wenberg JFM, Van Damme J, Meager $T$, Jeunhomme TMAA, Burman W, Effects of tumor necrosis factor on the interferon-y-induced major histocompatibility complex class II antigen expression by human endothelial cells. Eur. J. Immunol. 1988; 18: 1469.

42. Collart MA, Belin D, Vassalli $I$, de Kossodo $S$, Vassalli $P$. $\gamma$-interferon enhances macrophage transcription of tumot mecrosis factor/cachectin, interleukin 1, and urokinase genes, which are controlled by short-lived repressors. J. Exp. Med. 1986; 164: 2113.

43. Dupont E, Huygen K, Schandené L, Vandercruys M, Palfliet K, Wybran J. Influence of in vivo immunosuppressive drugs on production of lymphokines. Transplantation 1985; 39: 143.

44. Frey BM, Frey FJ, Holford NHG, Lozada F, Benet LZ. Prednisolone pharmacodynamics assessed by inhibition of the mixed lymphocyte reaction. Transplantation 1982; 33: 578 .

45. Ten Berge RJM. The influence of immunosuppressive drugs on human immunocompetence. Studies in wivo and in witro. Thesis, Amsterdam, 1983. 


\section{Cellular proliferation at the site of rat cardiac allografts and the influence of immunosuppressive therapy.}

Submitted for publication.

\section{Summary}

In this study we investigated cellular proliferation of $T$ cells and macrophages at the site of rat cardiac allografts and studied the influence of immunosuppressive therapy on the proliferative characteristics of these cell types. A bromodeoxyuridine labeling technique was used that allowed both the accurate detection of proliferative activity and the phenotypic characterization of cellular infiltrates within grafted tissue. In untreated recipients (BN - Lewis), T cytotoxic/suppressor cells as well as $\mathrm{T}$ helper cells showed proliferative activity at the site of the graft. The percentage of OX8 positive cells within the graft that showed proliferation ranged from $15 \%$ to $37 \%$. The percentage of $W 3 / 25$ positive cells within the graft that showed proliferation ranged from $25 \%$ to $30 \%$. In contrast, macrophages hardly showed proliferative activity within the graft, only $1-4 \%$ of the macrophages stained positive for bromodeoxyuridine. To test the influence of immunosuppressive therapy on cellular proliferation, the steroid budesonide was administered for 13 days, Budesonide treatment, $120 \mu \mathrm{g} / \mathrm{kg} /$ day, resulted in significant prolongation of alllograft survival; MST was 20 days versus 7 days in controls. During immunosuppressive therapy still a remarkable amount of infiltrating cells was present within the grafts. Moreover, immunosuppressive treatment did not appear to affect the proliferative capacity of the individual cell types. OX8 positive cells as well as W3/25 positive cells showed significant proliferative activity within the treated grafts.

From these observations it is concluded that the graft serves as a non-lymphoid tissue site wherein lymphocytes can freely proliferate and expand. The fact that effective steroid treatment did not interfere with cell proliferation at the site of the graft while tissue destruction did not occur, may throw new light on the effect of steroids at the site of the allograft. 


\section{Introduction}

After transplantation of vascularized allografts rejection is initiated by lymphocytes present within the graft. At the present time however, there is still controversy concerning the site of maturation and proliferation of these lymphoid cells (1-8). Originally it was proposed that sensitized cells mature and proliferate within the central lymphoid tissue and subsequently migrate, either specifically or non-specifically, as mature effector cells to the target tissue and mediate tissue destruction (1-4). Nemlander et al. showed that in the early days after transplantation extensive traffic of white cells occurs between the lymphoid tissue and the graft, however, on day 4 after transplantation the traffic declines and after this time there is relative little exchange between the compartments (9). This finding was confirmed by the elegant studies of Ascher et al. (5). These investigators placed sponge matrix allografts in recipient mice and irradiated the recipient on day 5 with the graft selectively shielded from irradiation. Anti-donor cytotoxic $\mathrm{T}$ cells developed to a high level in the shielded sponge matrix allografts leading to the conclusion that cytotoxic $T$ lymphocytes (CTL) could mature within the graft independent of the host lymphoid system from day 5 after transplantation. These observations suggest that cell proliferation occurs at the site of the allograft and may play an essential role during the process of rejection.

Immunosuppressive agents such as cyclosporin A and steroids show strong antiproliferative properties in vitro (10-12) and may interfere in this way with the rejection process at the site of the allograft. On the other hand, during effective immunosuppressive therapy with these drugs cellular infiltrates of mononuclear cells can clearly be observed within the graft in the absence of tissue destruction $(8,13-17)$.

In this study we investigated the proliferative capacities of $T$ cells and macrophages within rat cardiac allografts and determined the influence of effective immunosuppressive therapy on the proliferative behaviour of these cells within the graft.

\section{Materials and methods}

Animals. All experiments were performed with inbred Brown Norway $\left(\mathrm{RT}^{\mathrm{n}}\right)$ and Lewis ( $R T^{L}$ ) male rats between 2-3 months of age, obtained from the Department of Experimental Animal Services of the University of Limburg. Rats were supplied with acidified water and rat chow ad libitum.

Heart transplantation. Heterotopic cardiac transplantation was performed from Brown Norway to Lewis strain. Donor hearts were anastomosed to the recipient using end-to-side anastomoses between donor descending aorta and recipient abdominal aorta, and between donor pulmonary artery and recipient portal vein. Heartbeat was checked daily by palpation through the abdominal wall. For immunohistologi- 
cal studies allografts were excised at definite days after transplantation. During graft survival experiments rejection was taken as the complete absence of ventricular contraction and was confirmed by histopathological examination. In untreated animals median graft survival time (MST) was $7 \pm 1.1$ days $(\mathrm{n}=8)$.

Immunosuppressive treatment. The steroid, budesonide (kindly provided by $\mathrm{Dr}$. R. Brattsand, Draco, Lund, Sweden) was administered by continuous infusion into the jugular vein for 13 days. For this purpose a Silastic catheter (602-155 Silastic Tubing, Dow Corning, Midland, MI) was introduced into the jugular vein, guided to the abdominal cavity and connected to an implantable osmotic minipump (Model 2ML2 Alza, Palo Alto, CA). Pumps delivered budesonide at a constant rate of approximately $6 \mu \mathrm{l} / \mathrm{hr}$ from day 0 till day 13 after transplantation. Budesonide was dissolved in pyrogen free distilled water plus propandiol $66 \%$ without heparin, the dose of the drug was adjusted to body weight of the recipient at the day before transplantation. In all animals correct position of the catheter was checked at autopsy.

5-Bromodeoxyuridine labeling. To detect proliferative activity within the cardiac allografts animals received 5-bromodeoxyuridine (BrdU), $50 \mathrm{mg} / \mathrm{kg}$ body weight by bolus injection intraperitoneally. One hour after BrdU was administered animals were killed and allografts were excised. BrdU incorporates into DNA during the S phase of the cell cycle and hence detection of BrdU is indicative for proliferative activity (18-22).

Together with the cardiac allografts control tissues were removed. As positive reference tissue small intestine was excised, which normally shows proliferative mucosal cells $(23,24)$. The negative reference tissue was the own heart of the recipient; heart tissue normally does not show proliferative activity.

Monoclonal antibodies. To detect BrdU incorporation the monoclonal antibody anti-bromodeoxyuridine clone II B5 was used. This antibody has been described in detail earlier (22-24). For phenotypic characterization the following mouse anti-rat monoclonal antibodies were used; $W 3 / 25$, which mainly recognizes $T$ helper cells, but which also stains a subpopulation of macrophages; $O X 8$ reacting with $T$ cytotoxic/suppressor cells and a subpopulation of NK cells (Seralab, Crawley Down, United Kingdom); ED2, which is directed against membrane antigens of rat tissue macrophages and has been described in detail by Dijkstra (25), who kindly provided the antibody (Department of Histology, Free University, Amsterdam, The Netherlands). All monoclonal antibodies were used at saturating dilutions.

Immunohistological studies. Immediately after harvesting, tissue samples were embedded in Tissue TEK II (Miles Scientific, Naperville, IL) mounting medium and snap frozen in iso-pentane $\left(-70^{\circ} \mathrm{C}\right)$ or fixed in neutral buffered formalin for routine histological observations. For immunohistological studies cryostat sections of $5 \mu \mathrm{m}$ were cut, air dried, fixed in acetone, and stored at $-20^{\circ} \mathrm{C}$ until used. Immunohisto- 
logical studies with the monoclonal antibodies OX8, W3/25 and ED2 were performed using indirect immunoperoxidase staining. Briefly, slides were thawed at room temperature for 15 minutes, washed for 5 minutes in phosphate buffered saline (PBS) and then incubated with the appropriate mouse monoclonal antibody for 30 minutes at room temperature. Slides were washed again in PBS and subsequently incubated for 30 minutes with horseradish peroxidase-coupled rabbit anti-mouse immunoglobulin (Dako, Copenhagen, Denmark) diluted 1:100 in 10\% rat serum. After washing in PBS sections were developed with a solution of $0.5 \mathrm{mg} / \mathrm{ml} \mathrm{di-}$ aminobenzidine tetrahydrochloride (Serva, Heidelberg, FRG) and $0.01 \% \mathrm{H}_{2} \mathrm{O}_{2}$ in $0.05 \mathrm{M}$ Tris buffer pH 7.6. After 10 minutes slides were washed in tap water and counterstained with hematoxylin. For immunocytochemical detection of BrdU incorporation, tissue sections were incubated in $2 \mathrm{~N} \mathrm{HCL}$ at $37^{\circ} \mathrm{C}$ for 30 minutes, followed by washing twice in $0.1 \mathrm{M}$ sodiumtetraborate $\mathrm{pH} 8.5$. After washing in PBS, sections were incubated with the monoclonal antibody anti-BrdU. Incubation conditions and staining with the monoclonal anti-BrdU were similar to those described above. The only difference being the incubation with the monoclonal anti-BrdU at $37^{\circ} \mathrm{C}$. When double staining was performed, slides were first incubated with the monoclonal antibodies W $3 / 25$, OX8 or ED2 and stained using the indirect immunoperoxidase technique, however without counterstaining with hematoxylin. Subsequently slides were washed in PBS, treated as described above, and incubated with the second monoclonal antibody, anti-BrdU. After washing, slides were then incubated with fluorescein isothiocyanate (FITC) labeled rabbit Ig anti-mouse Ig for 30 minutes. Slides were washed again and examined by fluorescence microscopy. Using this procedure results were expressed as the percentage of cells positive for relevant phenotype staining positively with FITC. For parallel histologic observations formaline fixed tissue was processed in a routine manner and hematoxylin and eosin stained sections were examined.

Morphometric analysis of tissue sections. When indicated cellular infiltration within the grafts was quantified by morphometric analysis according to the method of McWhinnie (26). Cellular infiltration within a section was assessed by point counting using a square grid in the eyepiece of the microscope. The percentage area of each section occupied by cells staining positively with a particular monoclonal antibody was calculated as follows:

Percentage area infiltrated by positive cells

$$
=\frac{\text { number of positive cells under grid intersections }}{\text { total number of grid intersections }} \times 100 \%
$$

The accuracy of the technique is proportional to the number of points counted. To maintain a standard error of less than $10 \%, 4,250$ points were counted when density of the infiltrate was less than $10 \%, 600$ points were counted when density of the infiltrate was more than $10 \%$. For point counting a 120 point or 850 point graticule 
was used, within each section 5 fields were chosen at random and counted by a magnification of 400 .

\section{Results}

Proliferative characteristics of infiltrating cells in untreated cardiac allografts. Cardiac allograft recipients were injected with BrdU on day 3 and 5 after transplantation and tissues were removed for immunohistological studies. In all grafts removed, BrdU positive cells could clearly be observed. BrdU positive cells appeared within the graft parallel to cellular infiltration (Table 1). On day 3 after transplanta-

TABLE 1. Histopathological observations and proliferative activity in untreated cardiac allografts.

\begin{tabular}{llll}
\hline & $\begin{array}{l}\text { cellular } \\
\text { infiltrate }\end{array}$ & $\begin{array}{l}\text { BrdU } \\
\text { positive cells }\end{array}$ & $\begin{array}{l}\text { graft destruction, edema, } \\
\text { hemorrhage, necrosis }\end{array}$ \\
\hline day 3 & + & + & - \\
day 5 & +++ & +++ & ++ \\
\hline
\end{tabular}

Cardiac transplantation was performed from $B N$ to Lewis strain. On day 3 and 5 after transplantation BrdU labeling was performed as described in Materials and Methods and grafis were excised subsequently. Grafts were analyzed for the presence of cellular infiltrate, BrdU positive cells and signs of graft destruction. Data represent consistent observations made in all rats of the experimental group $(n=4)$.

tion BrdU positive cells could clearly be identified among the infiltrating cells within the graft; by the 5th day after transplantation the amount of BrdU positive cells, as well as the total amount of infiltrating cells was significantly increased. At this time grafts also showed significant signs of tissue destruction. Figure 1A shows the picture of a graft excised on day 5 after transplantation. Positive cells, scattered throughout the graft, are clearly observed. Staining with anti-BrdU is as expected intranuclear since BrdU incorporates during the $S$ phase of the cell cycle into DNA. Control tissues that normally show high proliferative activity such as small intestine stain clearly positive with anti-BrdU (Figure 1B). In contrast however, tissues that normally do not show proliferative activity, such as normal heart tissue, do not stain with anti-BrdU. Figure $1 \mathrm{C}$ shows the own heart of the recipient stained with antiBrdU, staining is clearly negative.

Next, the phenotype of the infiltrating cells was determined and related to proliferative activity. For this purpose a double staining technique was used as described in materialls and methods. Results of these stainings performed on grafts excised on day 5 after transplantation are given in table 2 . Cellular infiltrates were mainlly composed of macrophages and $\mathrm{T}$ cytotoxic/ suppressor cells. The area infiltrated by $\mathrm{T}$ cytotoxic/suppressor cells and macrophages ranged respectively from 18-26\% and 


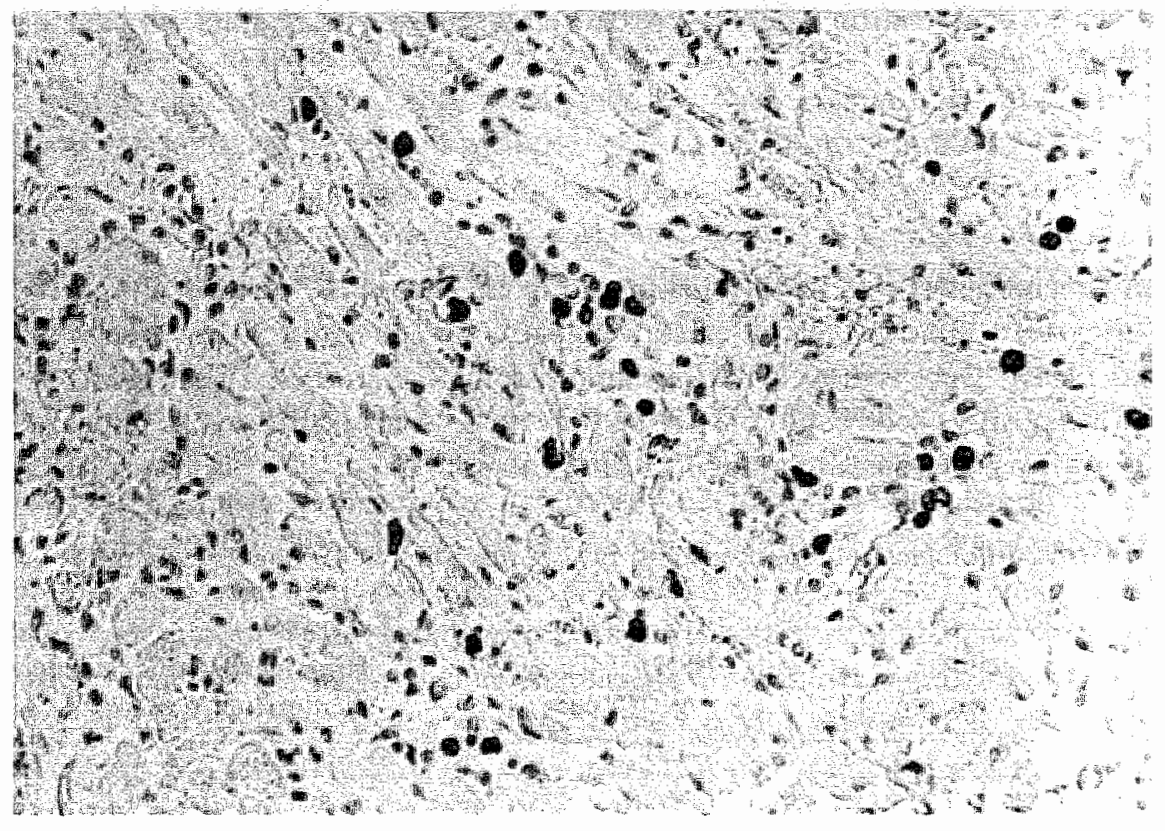

FIGURE LA. Untreated cardiac allograft removed on day 5 after iransplantation stained with ani-BrdU. Positive cells are scattered throughout the graft. (x294)

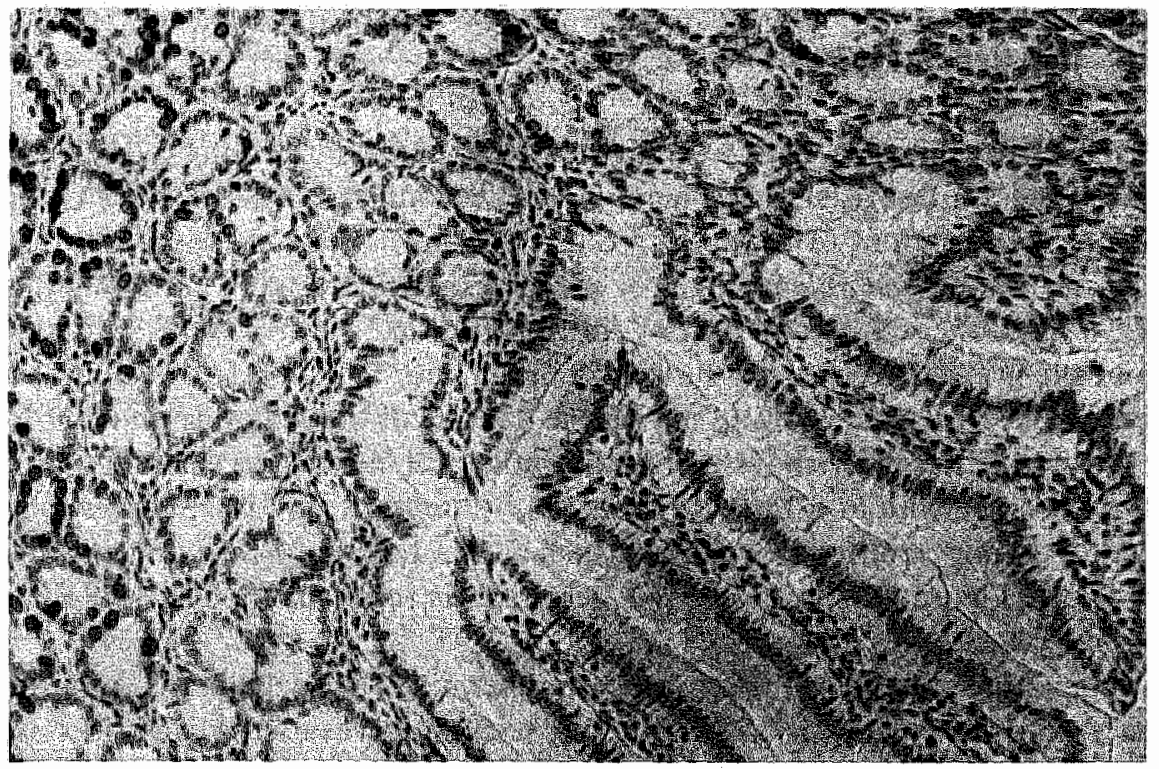

FIGURE 1B. Small intestine of normal Lewis rat stained with anti-BrdU. Positive cells are clearly observed. $(x 184)$ 


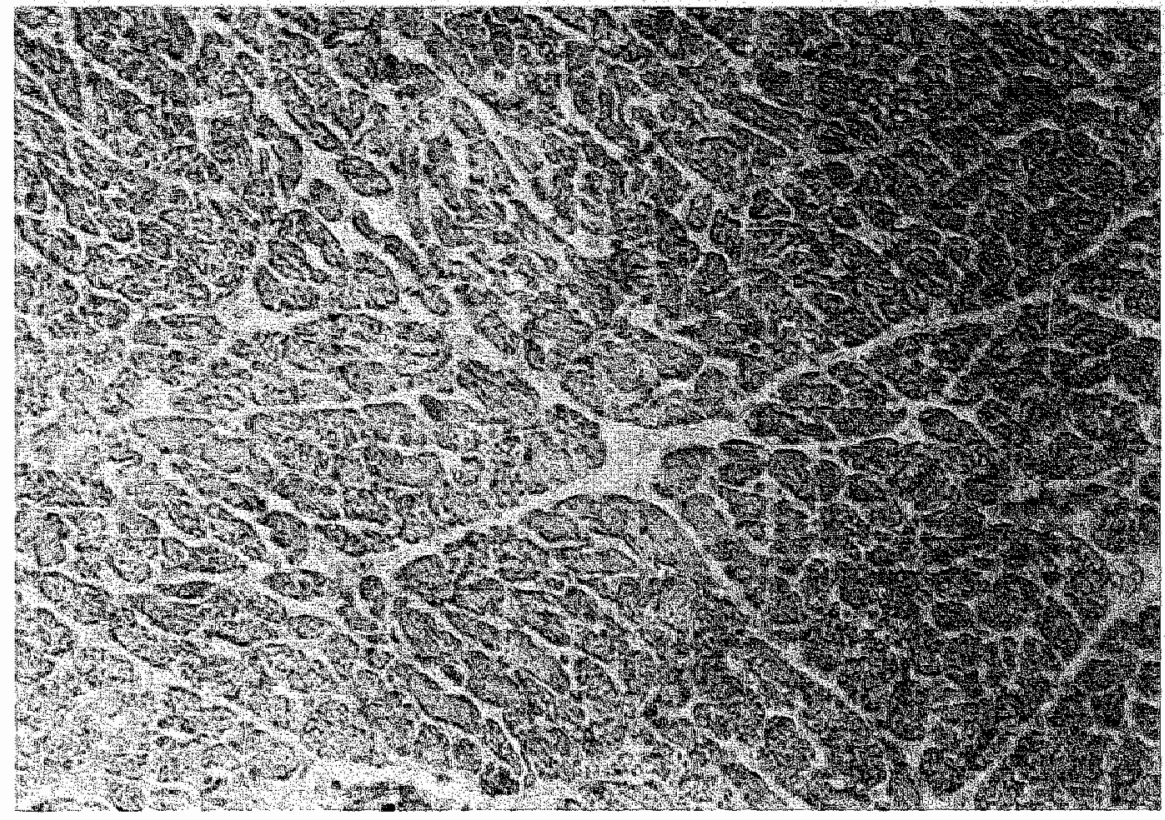

FIGURE IC. Normal heart of Lewis rat stained with anti-BrdU. Staining is completely negative. $(x 200)$

$17-26 \%$. T helper cells were in the minority, the area of infiltration ranged from 8 to $11 \%$. OX8 positive cells as well as $\mathrm{W} 3 / 25$ positive cells clearly showed proliferative activity within the graft. 15 to $37 \%$ of the OX8 positive cells present within the graft also stained positive with anti-BrdU. The percentage of $W 3 / 25$ positive cells that showed proliferation ranged from $25-30 \%$. In contrast only a few ED2 positive cells showed proliferative activity; 1 to $4 \%$ of all the ED2 positive cells stained also with anti-BrdU.

The effect of immunosuppressive therapy on the profile of cellular proliferation within the graft. To study the influence of immunosuppressive therapy on cellular proliferation within the graft animals were treated with the steroid budesonide. Continuous intravenous infusion of budesonide, which has been shown to be a potent immunosuppressive drug (27), resulted in significant prolongation of allograft survival. At a dosage of $120 \mu \mathrm{g} / \mathrm{kg} /$ day for 13 days, MST is prolonged to 20 days (Table 3); which means that the period between cessation of therapy and rejection equals the graft survival time of controls. In order to determine cellular proliferation, grafts from recipients treated with budesonide $(120 \mu \mathrm{g} / \mathrm{kg} /$ day) were excised on definite days after transplantation and stained with anti-BrdU. Results given in table 4 show that during immunosuppressive therapy cellular infiltration and $\mathrm{BrdU}$ positive cells were present on day 3 and 5 after transplantation (Figure 2), although 
TABLE 2. Phenotypic composition of the cellular infiltrate and relation to proliferative activity in untreated cardiac allografts on day 5 after transplantation.

percentage area infiltrated by positive cells percentage of cells positive for relevant phenotype positively staining for BrdU*

\begin{tabular}{|c|c|c|c|c|c|c|}
\hline \multirow[b]{2}{*}{$\begin{array}{l}\text { animal } \\
\text { No. }\end{array}$} & & \\
\hline & $\begin{array}{l}\text { OX8 } \\
\text { Te, Ts }\end{array}$ & $\begin{array}{l}\text { W3/25 } \\
\text { Th }\end{array}$ & $\begin{array}{l}\mathrm{ED} 2 \\
\mathrm{mo}\end{array}$ & $0 \times 8$ & $W 3 / 25$ & $\mathbb{E D} 2$ \\
\hline$\$ 10$ & 18 & 8 & 17 & 37 & 27 & 3 \\
\hline 511 & 20 & 11 & 20 & 18 & 30 & 4 \\
\hline 512 & 26 & 10 & 26 & 15 & 25 & 1 \\
\hline 513 & 19 & 9 & 21 & 30 & 26 & 3 \\
\hline
\end{tabular}

Cardiac transplantation was performed from $B N$ to Lewis rats. After BrdU labeling allografts were excised on day 5 after transplantation and immunohistological studies were performed.

cells positive for relevant phenotype

* $=\frac{\text { as well as positive for BrdU staining }}{\text { cells positive for relevant phenotype }} \times 100 \%$.

TABLE 3. Effect of budesonide treatment upon cardiac allograft survival in Lewis recipients receiving $\mathrm{BN}$ hearts.

\begin{tabular}{lll}
\hline treatment & $\begin{array}{l}\text { graft survival } \\
\text { (days) }\end{array}$ & MST* \\
\hline untreated & $\begin{array}{l}6.6 .6 .7 \\
7.8 .8 .9\end{array}$ & $7 \pm 1.1$ \\
& 6.6 .7 .7 & $7 \pm 1.1$ \\
solvent** & 7.8 .9 & \\
(propandiol) & 17.17 .18 .19 & $20 \pm 2.4^{*}$ \\
budesonide*** & 21.22 .22 .23 & \\
\hline
\end{tabular}

* $M S T=$ median graft survival time.

* The solvent propandiol 66\% was given by contimuous infusion into the jugular vein.

** Budesonide was administered by continuous infusion into the jugular vein from day 0 till day 13 after transplantation.

+ Wilcoxon rank test for difference between animals treated with budesonide and animals treated with the solvent $(p<0.01)$.

compared to untreated animals overall cellular infiltration and BrdU staining was lower. As in the untreated animals the appearance of BrdU positive cells parallels the appearance of cellular infiltration within the graft. In contrast to untreated animals it has to be noticed that despite cellular infiltration and positive BrdU staining, signs of graft destruction were absent during treatment. After cessation of ther- 
TABLE 4. Histopathological observations and prohlferative activity in cardiac allografts during immunosuppressive therapy.

\begin{tabular}{llll}
\hline & $\begin{array}{l}\text { cellular } \\
\text { infiltrate }\end{array}$ & $\begin{array}{l}\text { Brdu } \\
\text { positive cells }\end{array}$ & $\begin{array}{c}\text { graft destruction, edema; } \\
\text { hemorrhage, necrosis }\end{array}$ \\
\hline day 3 & + & + & - \\
day 5 & ++ & ++ & - \\
day 15 & +++ & ++ & ++ \\
\hline
\end{tabular}

Lewis recipients were treated with budesonide, $120 \mu \mathrm{g} / \mathrm{kg} / \mathrm{day}$, for 13 doys. After BrdU labeling grafts were excised on day 3,5 and 15 after transplantation. Grafts were analyzed for the presence of cellular infiltrate, BrdU positive cells, and signs of graft destruction. Data represent consistent abservations made in all rats of the experimental group $(n=4)$.

TABLE 5. Phenotypic composition of the cellular infiltrate and relation to proliferative activity in cardiac allografts on day 5 after transplantation during immunosuppressive therapy.

percentage area infiltrated by positive cells percentage of cells positive for relevant phenotype positively staining for BrdU*

\begin{tabular}{llllllll}
\cline { 7 - 8 } animal & OX8 & W3/25 & ED2 & & OX8 & W3/25 & ED2 \\
No. & Tc,Ts & Th & & & & \\
\hline 540 & 9 & 3 & 13 & 22 & 31 & 2 \\
541 & 6 & 3 & 6 & 35 & 34 & 9 \\
542 & 11 & 4 & 8 & 20 & 32 & 5 \\
543 & 11 & 5 & 12 & 30 & 26 & 3 \\
\hline
\end{tabular}

Cardiac transplantation was performed from BN to Lewis rats. After BrdU labeling atlografts were excised on day 5 after transplantation and immunohistological studies were performed.

$$
\begin{aligned}
& \text { cells positive for relevant phenotype } \\
* \quad & \frac{\text { as well as positive for BrdU staining }}{\text { cells positive for relevant phenotype }} \times 100 \% \text {. }
\end{aligned}
$$

apy (day 13) however, a clear increase in both cellular infiltration and BrdU positive cells was observed and signs of graft destruction became apparent (day 15 Table 4 + Figure 3).

To study more in detail the influence of effective immunosuppression on the proliferative characteristics of the different phenotypic cell types, grafts were removed during effective treatment (day 5) and the phenotypic composition of the infiltrate was analyzed together with the ability of the individual cell types to prolifer ate (Table 5). Although budesonide reduced overall cellular infiltration compared to untreated animals still a remarkable amount of $O \times 8$ positive and $W 3 / 25$ positive cells could be observed within the graft. It was most striking, however, to observe 


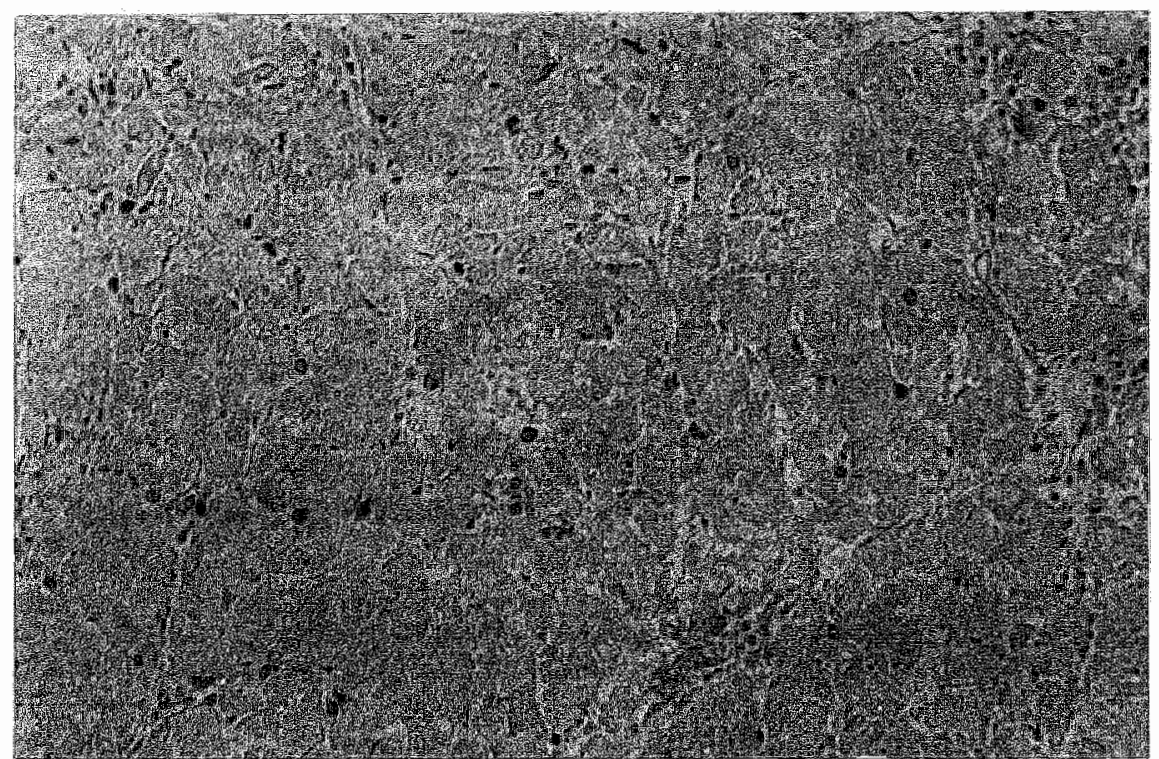

FIGURE 2. Graft removed on day 5 after transplantation from a Lewis recipient receiving immunosuppressive therapy with budesonide. Staining with anti-BrdU is clearly positive. $(x 184)$

that the steroid had no effect on the proliferative capacity of these individual cell types. The percentages of $\mathrm{OX} 8$ positive cells and $\mathrm{W} 3 / 25$ positive cells staining positive with anti-BrdU were comparable to those obtained in the untreated animals. From these data it appears that budesonide treatment hardly effects cellular proliferation within the graft. Despite the presence of these proliferative cells however, graft destruction did not occur during budesonide treatment.

\section{Discussion}

In this study we investigated the proliferative characteristics of $\mathrm{T}$ cells and macrophages in rat cardiac allografts and determined the influence of immunosuppressive therapy on proliferative activity. For this purpose a BrdU labeling technique was used. After injection the chemical BrdU incorporates into DNA during the $S$ phase of the cell cycle and subsequent detection of BrdU in tissue sections reflects proliferative activity of the tissue under study (18-24). The major advantage of the BrdU labeling technique is that the method allows the detection of cellular proliferation at the site of tissue allografts without the need for enzymatic digestion or autoradiography. Proliferative cells can be detected without manipulation and can be ob- 


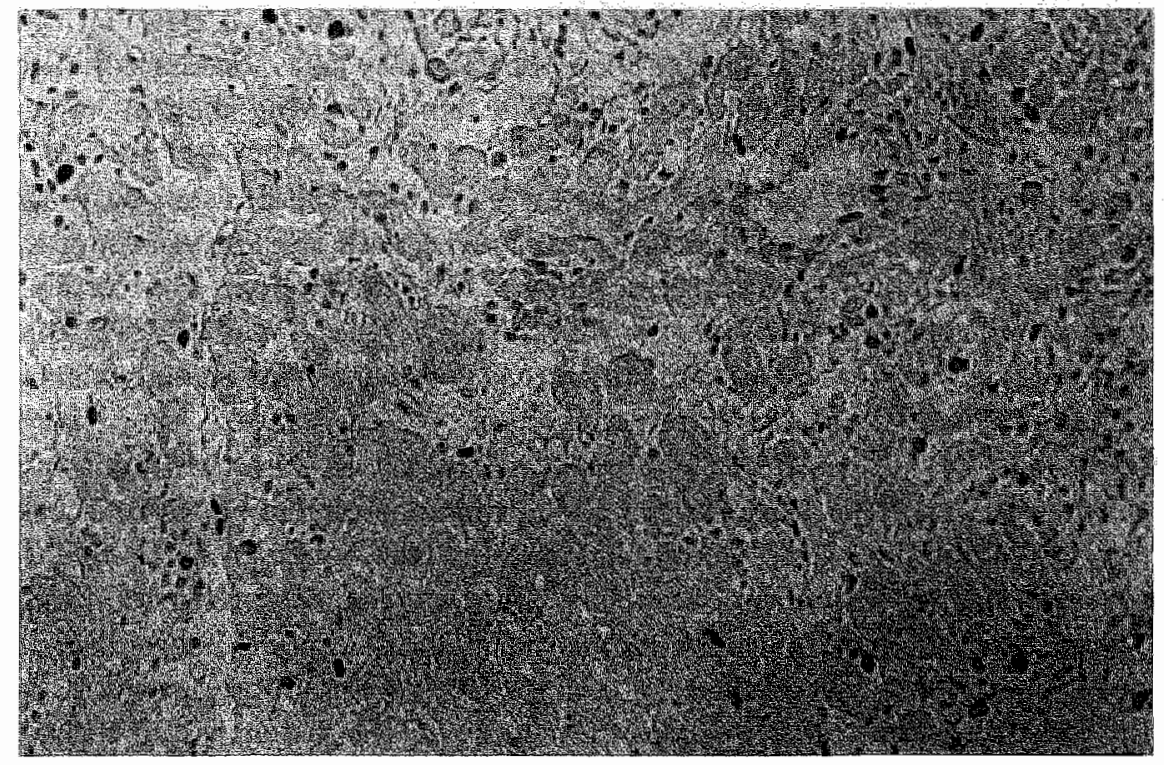

FIGURE 3. Graft removed on day 15 after iransplantation from a Lewis recipient that had received immunosuppressive therapy for 13 days. Compared to day 5 (Figure 2) an increase in cellular infiltration is observed while signs of graft destruction become apparent. (x184)

served within the histopathological context of the allograft.

Grafts excised from untreated animals showed a substantial amount of proliferative cells. Positive cells were scattered throughout the graft and were not especially related to the neighbourhood of small vessels. This demonstrates that positive cells indeed proliferate within the graft since it is unlikely that these cells incorporated BrdU outside the graft and subsequently infiltrated within the graft within 1 hour after BrdU labeling. OX 8 positive cells as well as $\mathrm{W} 3 / 25$ positive cells stained positive with anti-BrdU. The fact that $\mathrm{OX} 8$ positive cells showed proliferative activity within the graft corresponds to earlier observations made by others in the sponge matrix allograft model (5). In addition our data show that also W3/25 positive cells proliferate within the graft. The percentage of $T$ helper cells that showed proliferation ranged from $25-30 \%$. Although the present study does not specifically address the mechanisms of graft rejection, the observation that $T$ helper cells proliferate within the graft supports the link between DTH and allograft rejection as demonstrated by others (28-30). Akin to DTH reactions, a significant proportion of the cellular infiltrate consisted of macrophages. Proliferation of macrophages however was hardly seen within the grafts, which means that recruitment by lymphokines such as migration inhibitory factor, has to play an essential role during macrophage infiltration within the graft as is observed in other inflammatory reactions. Also other 
studies $(8,31,32)$ demonstrated prominent macrophage infiltration in vascularized allografts which has prompted speculations that macrophages or macrophage produets (33) play an active role in mediating tissue damage during allograft rejection.

From the data obtained in the untreated recipients it can be concluded that the graft serves as a non-lymphoid tissue site wherein lymphocytes with $\mathrm{T}$ cytotoxic/suppressor phenotype as well as with $\mathrm{T}$ helper phenotype can freely proliferate. This certainly allows the production of lymphokines within the graft (8) and hence the recruitment of macrophages and other inflammatory cells responsible for the augmentation and effector functions of the immune response.

In the second part of the study we investigated the effect of immunosuppressive therapy on cellular proliferation within the graft. Immunosuppression was induced by the steroid budesonide. This steroid has been shown to possess strong immunosuppressive properties and potency of the drug was described 10 to 100 times higher than of prednisolone (27,34-36). In our transplantation model budesonide at a dosage of $120 \mu \mathrm{g} / \mathrm{kg} /$ day for 13 days resulted in effective immunosuppression, at this dosage MST was significantly prolonged to 20 days. When grafts were excised on day 3 and 5 after transplantation immunosuppression was optimal and no signs of tissue destruction were observed. Despite effective treatment still a remarkable amount of infiltrating cells could be observed. This finding is in agreement to other reports that describe cellular infiltration during effective immunosuppression $(8,13-17)$. Our data, however, extend these observations by showing that also cellular proliferation within the graft is not inhibited by immunosuppressive therapy. To explain the presence of proliferative cells within the graft during treatment, one could speculate that budesonide primarily act systemically while drug concentrations within the graft were too low to inhibit cell proliferation. This hypothesis, however, is unlikely since earlier experiments with budesonide in this cardiac al$\operatorname{lograft}$ model showed that systemic budesonide delivery at a dose of $120 \mu \mathrm{g} / \mathrm{kg} / \mathrm{day}$ resulted in drug plasma levels of $1.65 \mathrm{ng} / \mathrm{ml}$ and drug levels within the graft of 31 $\mathrm{ng} / \mathrm{mg}$ (27), which means that despite high budesonide levels within the graft cell proliferation takes place.

The observation that cellular proliferation occurs within the graft while signs of graft destruction are absent is intriguing. This finding questions the importance of the anti-proliferative effect of steroids as described in vitro $(37,38)$. In contrast, however, it suggests the importance of other immunosuppressive effects of the drugs. For example the production of mediators which have been associated with the induction of tissue destruction such as interleukin 1 and tumor necrosis factor, is known to be inhibited by steroids $(33,39,40)$. Moreover it was observed recently, that inhibition of interferon-gamma production within rat renal allografts, treated by local steroid administration, was associated with prevention of graft destruction. Further investigations are necessary concerning the action of steroids in this direction.

From the data presented in this study it is concluded that $\mathrm{T}$ lymphocytes of $\mathrm{T}$ helper 
as well as of T cytotoxic/suppressor phenotype are capable to proliferate at the site of the allograft. Immunosuppressive therapy with steroids does not affect the proliferative capacity of these cells within the graft. The observation that effective budesonide treatment does not inhibit cell proliferation within the allograft while tissue destruction is clearly prevented by the drug may throw new light on the effect of immunosuppressive drugs, and steroids in particular, at the site of the allograft.

Acknowledgments. We thank Mrs. M.M.J. Reynders and Mr. J.J. van Dongen for technical assistance, and Mrs. C.M.P. Spronck for typing the manuscript.

Abbreviations used in this paper: BrdU, 5-bromodeoxyuridine; CTL, cytotoxic T lymphocytes; FITC, fluorescein isothiocyanate; MST, median graft survival time; PBS, phosphate buffered saline.

\section{References}

1. Strom, T.B., N.L. Tilney, J.M. Paradys., J. Bancewicz and C.B. Carpenter. 1977. Cellular components of allograft rejection: identity, specificity and cytotoxic function of cells infiltrating acutely rejecting allografts. J. Immunol. 118: 2020.

2. Sprent, J. and J.F.A.P. Miller. 1976. Fate of H-2 activated T lymphocytes in syngeneic hosts. II. Residence in recirculating lymphocyte pool and capacity to migrate to allografts. Cell. Immunol. 21:303.

3. Tilney, N.L. and W.L. Ford. 1974. The migration of rat lymphoid cells into skin grafts; some sensitized cells localize preferentially in specific allografts. Transplantation 17:12.

4. Hall, J.G. 1967. Studies on the cells in the afferent and efferent lymph of lymph nodes draining the site of skin homografts. J. Exp. Med. 125:737.

5. Ascher N.L., S. Chen, R.A. Hoffman and R.L. Simmons. 1983. Maturation of cytotoxic T cells within sponge matrix allografts. J. Immunol. 131:617.

6. Orosz C.C., N.E. Zinn, L. Sirinek and R.M. Fergusson 1986. In wivo mechanisms of alloreactivity II. Allospecificity of cytotoxic T lymphocytes in sponge matrix allografts as determined by liming dilution analysis. Transplantation $41: 84$.

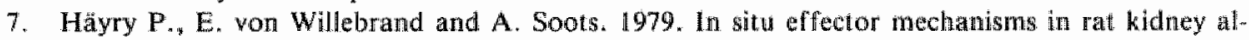
lograft rejection. III Kinetics of the inflammatory response and generation of donor-directed killer cells. Scand. J. Immunol. 10:95.

8. Ruers T.J.M., W.A. Buturman, C.J. wan Boxtel, C.J. van der Linden and G. Kootstra. 1987. Immunohistological observations in rat kidney allografts after local steroid administration. J. Exp. Med. 166:1205.

9. Nemlander A., A. Soots, E. won Willebrand, B. Husberg and P. Häyry. 1982. Redistribution of renal allograft responding leucocytes during rejection. II Kinetics and specificity. J. Exp. Med. 156:1087.

10. Hess A.D. and P.J. Tutschka. 1980. Effect of cyclosporin A on human lymphocyte responses in vitro. I. CS-A allows for the expression of alloantigen-activated suppressor cells while preferentially inhibiting the induction of cytolytic effector lymphocytes in MLR. J. Immunol, 124:2601.

11. Larsson E. L. 1980. Cyclosporin A and dexamethasone suppress $T$ cell responses by selectively acting at distinct sites of the triggering process. J. Immunol. 124:2828.

12. Cupps T.R. and A.S. Fauci. 1982. Corticosteroid-mediated immunoregulation in man. Immunological Rev. 65:133. 
13. Homan W.P., J.W. Fabre, K.A. Williams, P.R. Millard and P.J. Morris. 1980. Studies on the immunosuppressive properties of cyclosporin $A$ in rats receiving renal allografts. Transplantation 29:361.

14. Homan W.P., J.W. Fabre, P.R. Millard and P.J. Morris. 1980. Effect of cyclosporin A upon se. cond set rejection of rat renal allografts, Transplantation $30: 354$.

15. Mason D.W. and P.J. Morris 1984. Imhibition of the accumulation in rat kidney allografts, of specific - but not nonspecific - cytotoxic cells by cyclosporine. Transplantation 37:46.

16. Hayry $\mathrm{P}$. and $\mathrm{E}$. von Willebrand. 1986. The infuence of the pattern of inflammation and administration of steroids on class II MHC antigen expression in renal transplants. Transplantation $42: 358$.

17. Ruers T.J.M., W.A. Buurman, J.F.M. Smits, C.J. van der Linden, J.J. van Dongen, E.E.M. Spronken and $\mathrm{G}$. Kootstra. 1986. The effect of intrarenal steroid infusion on rat renal allograft rejection. Transplant. Proc. 18:1106.

18. Hoshino T, T. Nagashima, J. Murovic, E.M. Levin, V.A. Levin, S.M. Rupp. 1985. Cell kinetic studies of in situ human brain tumors with bromodeoxyuridine "Cytometry 6:627.

19. Morstijn C., S.M. Hsu, T. Kinsella, H. Gratzmer, A. Russo, J.B. Mitchell. 1983. Bromodeoxyuridine in tumors and chromosomes detected with monoclonal antibody $\mathrm{J}$. Clin. Invest. 72: 1844.

20. Pallavicini M.G., L. J. Summers, F.D. Dolbeare, J.W. Gray, 1985. Cytokinetic properties of a symchronous and cytosine arabinosidle perturbed murine tumor measured by simultaneous bromodeoxyuridine/DNA analysis. Cytometry 6:602.

21. Dolbeare F.A., H.G. Gratzner, M.G. Pallavicine, J.W. Gray. 1983. Flowcytometric measurement of total DNA content and in corporated bromodeoxyuridine. Proc. Natl. Acad. Sei. USA 80: 5573.

22. Schutte B., M.M.J. Reynders, C.L.M.V.J. van Assche, P.S.G.J. Hupperets, F.T. Bosman, G.H. Blijham. 1987. Studies with anti-bromodeoxyuridine antibodies. 1. An improved method for immunocytochemical detection of BrdU labeled nuclei using flow cytometry. Cytometry 8:372.

23. Schutte B., M.M.J. Reynders, F.T. Bosman, G.H. Bitharn, 1987. The effect of tissue fixation on anti-bromodeoxyuridine immuniohistochemistry. J. Histochem. Cytochem. 35:1343.

24. Schutte B., M.M.J. Reynders, F.T. Bosman, G.H. Blijham. 1987. Studies with antibromodeoxyuridine antibodies. II Simultaneous immunocytachemical detection of antigen expression and DNA synthesis by in vivo labeling of mouse intestinal mucosa. J. Histochem. Cytochem. $35: 371$.

25. Dijkstra C.D., E.A. Döpp, P. Joling and G. Kraal. 1985. The heterogeneity of mononuclear phagocytes in lymphoid organs: distinct macrophage subpopulations in the rat recognized by monoclonal antibodies ED1, ED2 and ED3 Immunology $54: 589$.

26. McWhinnie D.L., J.F. Thompson, H.M. Taylor, J.R. Chapman, E.M. Bolton, N.P. Carter, R.F.M. Wood and P.J. Morris. 1986. Morphometric analysis of cellular infiltration assessed by monoclonal antibody labeling in sequential human renal allograft biopsies. Transplantation 42:35:

27. Ruers T.J.M., M. Daemen, H. Thijssen, C.J. van der Linden and W.A. Buurman. Graft rejection. in rats proves sensitive to local immunosuppressive therapy. Transplantation: in press.

28. Mason D.W., M.J. Dallman, R.P. Arthur and P.J. Morris. 1984. Mechanisms of allograft rejection: the roles of cytotoxic $T$ cells and delayed-type hypersensitivity. Immunol. Rev. 77: 167.

29. Loveland B.E., P.M. Hogarth, Rh. Ceredig and I.F.C. McKenzje. 1981. Cells mediating graft rejeetion in the mouse. 1. Lyt-1 cells mediate skin graft rejection. J. Exp. Med. 153:1044.

30. Lowry R.P., D.M. Marghesco, J.H. Blackburn. 1985. Immune mechanisms in organ allograft rejection. VI. Delayed-type hypersensitivity and lymphotoxin in experimental renal allograft rejection. Transplantation 40:183.

31. MacPherson G.G. and S.E. Christmas. 1984. The role of the macrophage in cardiac allograft rejec tion in the rat. Immunol. Rev. 77:143.

32. Hancock W.W. 1984. Analysis of intragraft effector mechanisms associated with human renal allograft rejection: immunohistological studies, with monoclonal antibodies. Immunol. Rev. 77:61.

33. Lowry R.P., D. Blais, D. Marghesco and W.S. Powell. 1987. Immune effector mechanisms in organ allograft rejection. VIIll: Inflammatory mediators and cytotoxins in rejecting rat cardiac allografts. Transplant. Proc. XIX:424.

34. Brattsand R., A. Thalen, K. Roempke, L. Källström and E. Gruvstad. 1982. Influence of 16\%, 17 $\alpha-$ acetal substitution and steroid nucleus fluorination on the topical to systemic activity ratio of glucoconticoids. J. Steroid Biochem. 16: 779. 
35. Dahlberg E., A. Thalen, R. Brattsand, J. Gustafisson, U. Johansson, K. Roempke and T. Saartok. 1984. Correlation between chenical structure, receptor binding, and biological activity of some

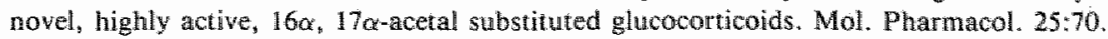

36. Edsbäcker S. 1986. Studies on the metabolic fate and human pharmacokinetics of budesonide. Thesis, S. Edbäcker, University of Lund, Sweden.

37. Roath S. and G. Cuppari. 1965. The effects of steroids on cultured lymphocytes. Clin. Res. 13:542.

38. Rosenberg J.C. and K. Lysz. 1980. Suppression of the immune response by steroids. Transplanta tion $29: 425$.

39. Snyder D.S. and E.R. Unanue. 1982. Corticoids inhibit murine macrophage la expression and interleukin 1 production. J. Immunol. 129:1803.

40. Waage A. and O. Bakke. 1988. Glucocorticoids suppress the production of tumor mecrosis factor by lipopolysaccharide stimulated human monocytes. Immunology 63:299. 



\section{Publications presented in this thesis}

1. TJM Ruers, WA Buurman, CJ van der Linden, $G$ Kootstra. Complete suppression of skin allograft rejection in rats treated with continuous infusion of $2^{\prime}$ deoxycoformycin. Transplantation 1985;40:137.

2. TJM. Ruers, CJ van der Linden, WA Buurman, G Kootstra. 2' Deoxycoformycin : A new immunosuppressive drug with a potency comparable to cy. closporine. Transplant Proc 1985;17:1333.

3. TJM Ruers, WA Buurman, JFM Smits, CJ van der Linden, JJ van Dongen, HAJ Struyker Boudier, G Kootstra. Local treatment of renal allografts, a promising way to reduce the dosage of immunosuppressive drugs. Transplantation 1986;41:156.

4. TJM Ruers, WA Buurman, CJ van der Linden, JJ van Dongen, G Kootstra. Renal pro-drugs offer new perspectives in immunosuppressive therapy. Transplant Proc 1986;18:907.

5. TJM Ruers, WA Buurman, JFM Smits, CJ van der Linden, JJ van Dongen, EEM Spronken, G Kootstra. The effect of intrarenal steroid infusion on rat renal allograft rejection. Transplant Proc 1986;18:1106.

6. TJM Ruers, WA Burman, CJ van der Linden. 2' Deoxycoformycin and deoxyadenosine affect IL2 production and IL2 receptor expression of human T cells. J Immunol 1987;138:116.

7. TJM Ruers, WA Buurman, CJ van der Linden, G Kootstra. Local inhibition of Major Histocompatibility Complex Class II induction within the graft: an effective way to induce immunosuppression. Transplant Proc 1987;19:246.

8. TJM Ruers, WA Buurman, CJ van der Linden, G Kootstra. Inhibition of lymphocyte specific enzymes: a promising approach for selective immunosuppression. Transplant Proc 1987;19:1287.

9. TJM Ruers, EEM Spronken, WA Buurman. The influence of prednisolone on the regulation of Major Histocompatibility Complex Class II expression. Transplant Proc 1987; 19:4227.

10. TJM Ruers, WA Buurman, CJ van Boxtel, CJ van der Linden, G Kootstra. Immunohistological observations in rat kidney allografts after local steroid administration. J Exp Med 1987;166:1205. 
11. TJM Ruers, WA Buurman. Local immune modulation within allografts. In: modulation of the immune response, Alan R. Liss, Inc, New York. (in press).

12. TJM Ruers, MJAP Daemen, HHW Thijssen, CJ van der Linden, WA Buurman. Graft rejection in rats proves sensitive to local immunosuppressive therapy. Transplantation (in press, December 1988).

13. TJM Ruers, JFM Leeuwenberg, EEM Spronken, CJ van der Linden, WA Buurman. The effect of steroids on the regulation of MHC class Ill expression on human non-lymphoid tissue. Transplantation (in press).

14. TJM Ruers, WA Buurman, CJ van der Linden. The relative importance of local versus systemic immune response in allograft rejection. Transplant Proc (in press).

15. TJM Ruers, EEM Spronken, WA Buurman. The effect of steroids on the production of non-IFN- $\gamma$ MHC class II inducing mediators. Transplant Proc (in press).

16. TJM Ruers, WA Buurman, JJ van Dongen, $C J$ van der Linden. Graft rejection can effectively be treated by local immunosuppression in the absence of systemic immunosuppression. Transplant Proc (in press).

17. TJM Ruers, B Schutte, CJ van der Linden, JJ van Dongen, WA Buurman. Cellular proliferation at the site of rat cardiac allografts and the influence of immunosuppressive therapy. (submitted). 


\section{Acknowledgments}

During the work on this thesis I enjoyed the help and friendship of many people to whom I would like to express my gratitude.

First of all I want to thank my wife Claire for her moral support and patience during the past years. I am also grateful to my parents who provided a solid start to life.

Prof. Dr. G. Kootstra, your tactful guidance and support made it possible to perform the work in the laboratory. Your interest and characteristic optimism stimulated and helped me to realize this thesis.

Dr. W.A. Buurman, you introduced me into the field of immunology and taught me the basic principles of science. The experiments were accomplished with your enthusiastic support.

Dr. C.J. van der Linden, you were always willing to help. Extensive discussions with you significantly improved the quality of this thesis.

Prof. Dr. J.M. Greep, you have created an infrastructure within our department that allows scientific research.

I am grateful to Mr. J.J van Dongen for his technical assistance and support. I thank Mrs. E.E.M. Spronken, Mrs. A.J.J.M. Daemen and Mrs. G.M.A.A. Jeunhomme for their help and energy spent to realize this thesis. I am very much obliged to Mrs. C.M.P. Spronck for typing the manuscripts.

I thank the Department of Pharmacology, Prof. Dr. H.A.J. Struyker Boudier, Dr. H.H.W. Thijssen, Dr. J.F.M. Smits, Dr. M.J.A.P. Daemen and their co-workers, for their co-operation and advice. I appreciated their hospitality.

It thank Dr. B. Schutte, Dr. G. Groenewegen, Dr. J.F.M. Leeuwenberg, Dr. M.G. Havenith, Dr. W. Dinjens, Dr. C.J. van Boxtel, Mrs. M.M.J. Reynders and Mr. C. Voskamp who all contributed to different aspects of this thesis.

I am grateful to the personnel of the Department of Experimental Animal Facilities ( head Dr. T. van den Bogaard) for all their help.

I thank the referees of this thesis, Dr. T. Beveridge, Prof. Dr. F.T. Bosman, Prof. Dr. R.A.P. Koene, Prof. Dr. H.A.J. Struyker Boudier and Prof. Dr. N.L. Tilney, for reviewing the final manuscript.

Finally, I feel much obliged to all my colleagues and members in the Department of Surgery for their support during the final years of this thesis, when I was employed as a resident in surgery. 


\section{Curriculum vitae}

Theo Ruers was born on 5th December 1956 in Sittard, The Netherlands. He attended atheneum B at "Bernardinus College" in Heerlen, where he graduated in 1975. He studied at the Medical Faculty of the University of Limburg in Maastricht from 1975 to 1981. After graduation he worked as a resident at the Department of Internal Medicine at the Luisenhospital in Aachen, FRG (Head: Prof. Dr. K. Krentz). From 1983 to 1986 he was employed as transplant co-ordinator and involved in experimental research at the Department of Surgery of the Academic Hospital Maastricht (Head: Prof. Dr. J.M. Greep/Prof. Dr. G. Kootstra). In 1986 he started as a resident in surgery at the same department. 
Met dank aan de Nierstichting Nederland, Stichting Dr. Ir. J.H.J. van de Laar, Astra BV, Lederle BV, Pharmachemie, Roussel BV, Sandoz BV, Sarva-Syntex BV.

Druk: Groenevelt bv, Landgraaf 